\title{
Surgical treatment of defecation disorders
}

Citation for published version (APA):

Melenhorst, J. (2015). Surgical treatment of defecation disorders. [Doctoral Thesis, Maastricht University]. Datawyse / Universitaire Pers Maastricht. https://doi.org/10.26481/dis.20151204jm

Document status and date:

Published: 01/01/2015

DOI:

10.26481/dis.20151204jm

Document Version:

Publisher's PDF, also known as Version of record

\section{Please check the document version of this publication:}

- A submitted manuscript is the version of the article upon submission and before peer-review. There can be important differences between the submitted version and the official published version of record.

People interested in the research are advised to contact the author for the final version of the publication, or visit the DOI to the publisher's website.

- The final author version and the galley proof are versions of the publication after peer review.

- The final published version features the final layout of the paper including the volume, issue and page numbers.

Link to publication

\footnotetext{
General rights rights.

- You may freely distribute the URL identifying the publication in the public portal. please follow below link for the End User Agreement:

www.umlib.nl/taverne-license

Take down policy

If you believe that this document breaches copyright please contact us at:

repository@maastrichtuniversity.nl

providing details and we will investigate your claim.
}

Copyright and moral rights for the publications made accessible in the public portal are retained by the authors and/or other copyright owners and it is a condition of accessing publications that users recognise and abide by the legal requirements associated with these

- Users may download and print one copy of any publication from the public portal for the purpose of private study or research.

- You may not further distribute the material or use it for any profit-making activity or commercial gain

If the publication is distributed under the terms of Article $25 \mathrm{fa}$ of the Dutch Copyright Act, indicated by the "Taverne" license above, 


\section{Surgical treatment of defecation disorders}

Jarno Melenhorst 


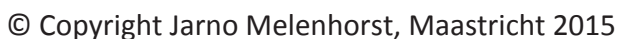

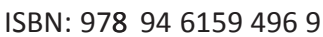

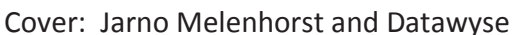

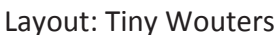

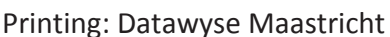

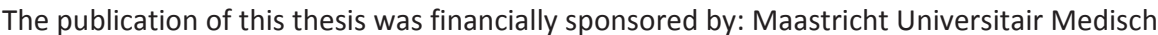

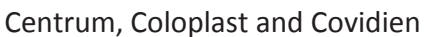

\section{Coloplast}




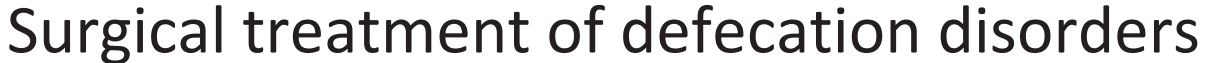

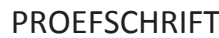

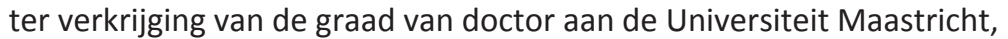

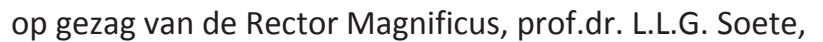

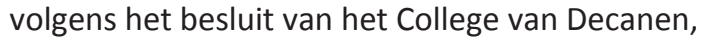

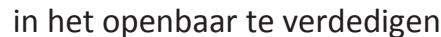

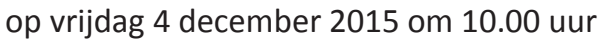

ㅇ?ㅇ?ㄴ?

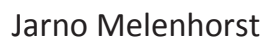

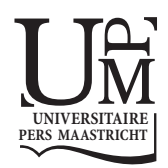




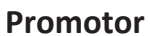

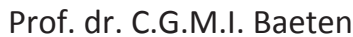

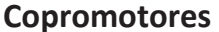

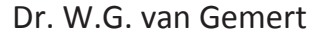

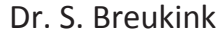

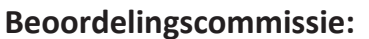

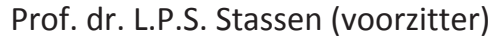

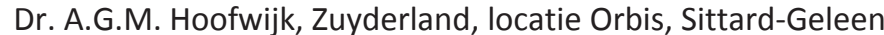

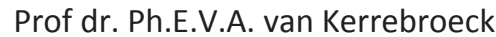

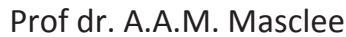

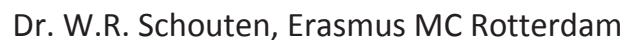




\section{Contents}

$\begin{array}{lll}\text { Chapter } 1 & \text { Introduction } & 7\end{array}$

- Nederlandse introductie

Chapter 2 Dynamic Graciloplasty for fecal incontinence. Long term prospective follow-up in a single center

Chapter 3 The artificial bowel sphincter for faecal incontinence: a single centre study

Chapter $4 \quad$ Sacral neuromodulation in patients with faecal incontinence: $\quad 49$ results of the first 100 permanent implantations

Chapter 5 Is a morphologically intact anal sphincter necessary for success with sacral nerve modulation in patients with faecal incontinence?

Chapter 6 Sacral nerve stimulation for intractable constipation

Chapter 7 Summary and future perspectives

- Samenvatting en toekomstperspectieven

Valorisation

Dankwoord

Publicaties 



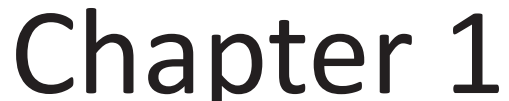

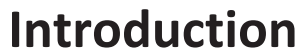




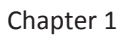




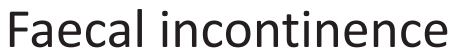

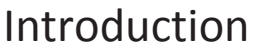

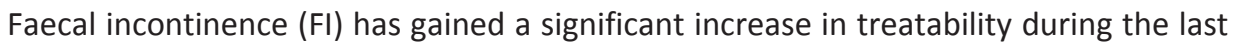

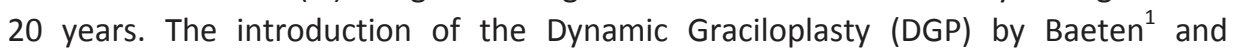

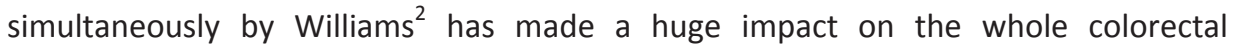

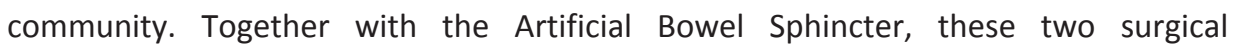

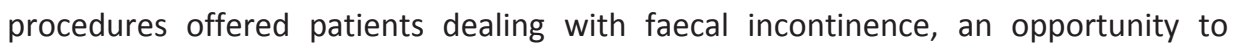

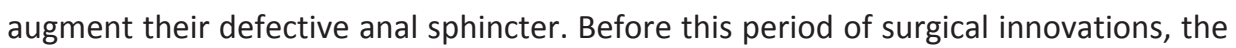

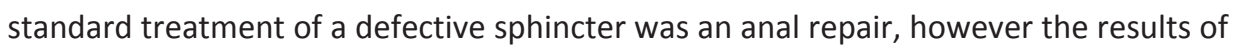

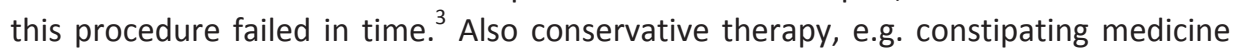

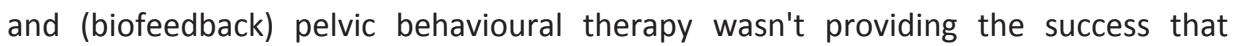

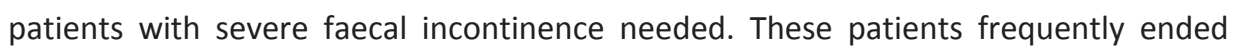

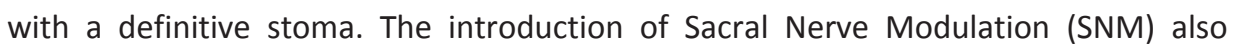

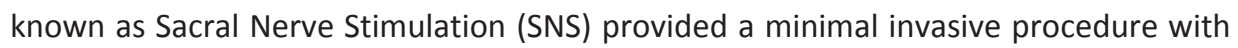

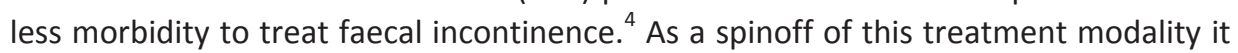

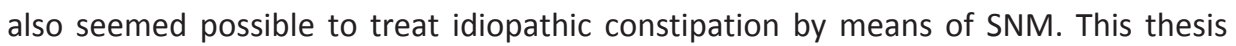

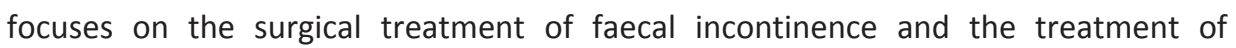

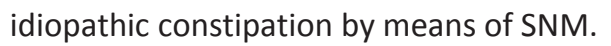

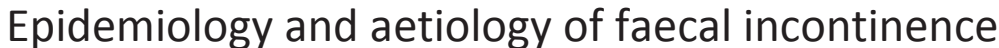

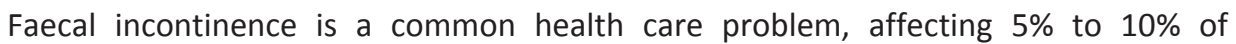

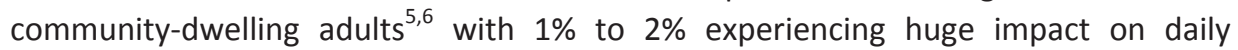

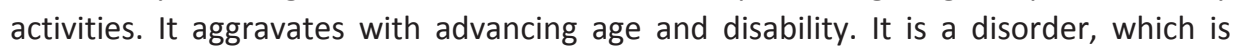

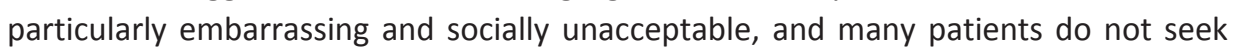

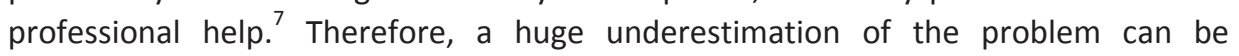

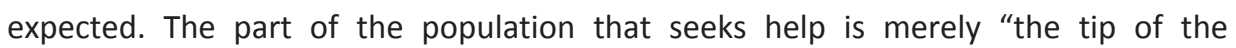
[5

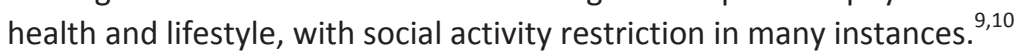

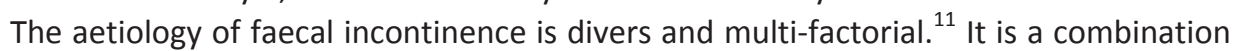

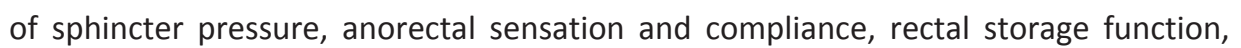

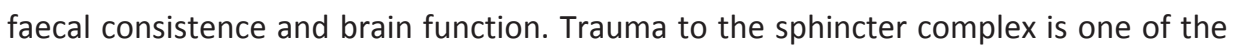

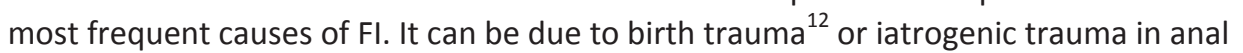

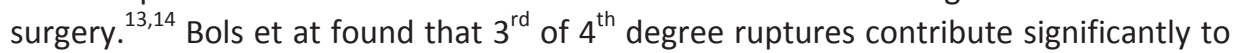

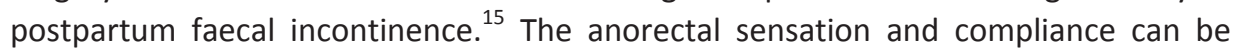

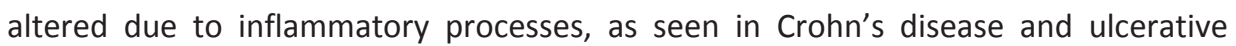

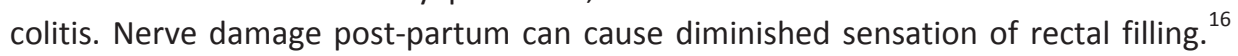

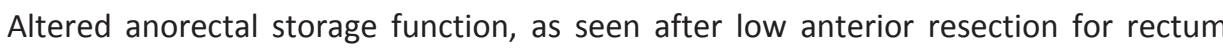

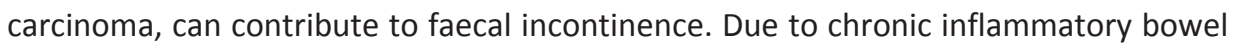
[?] 


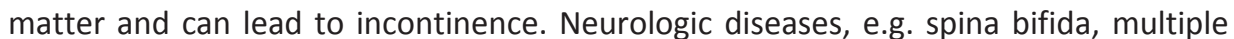

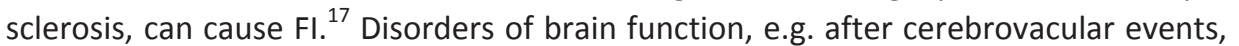

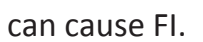

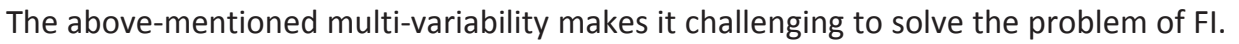

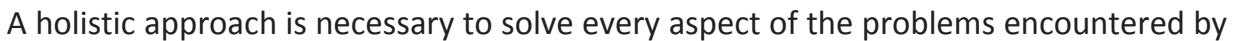

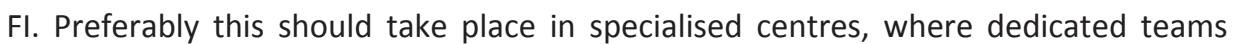

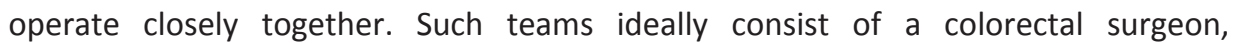

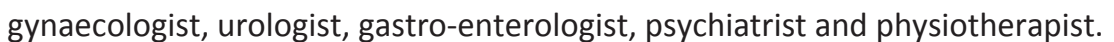

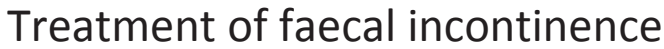

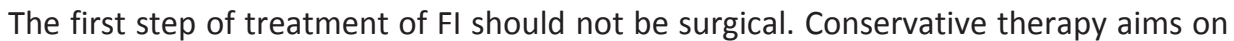

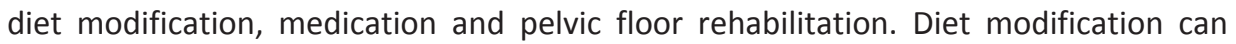

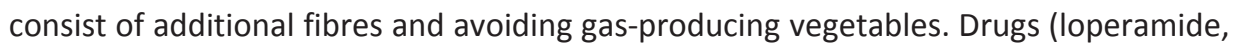

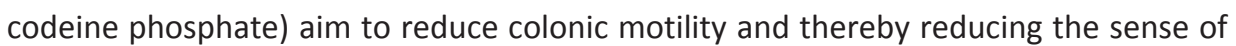

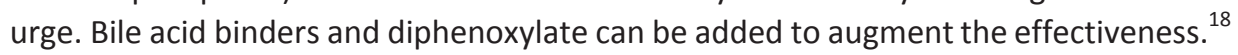

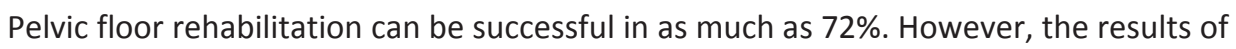

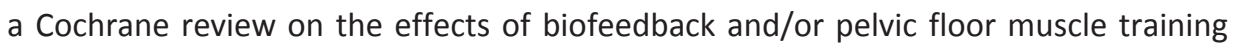

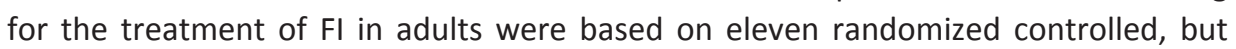

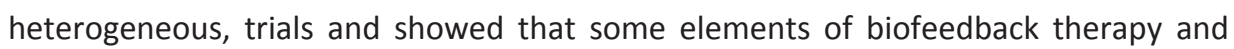

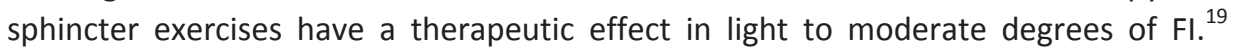

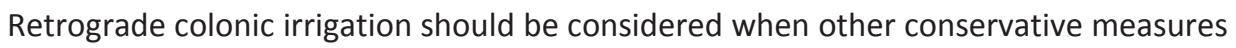

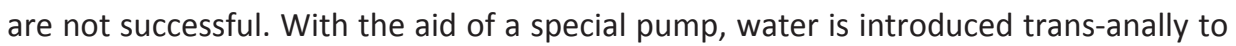

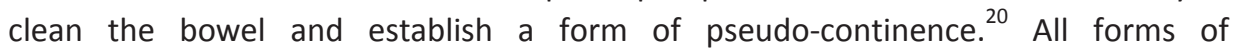

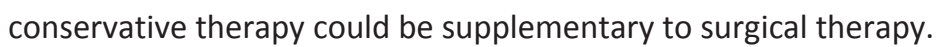

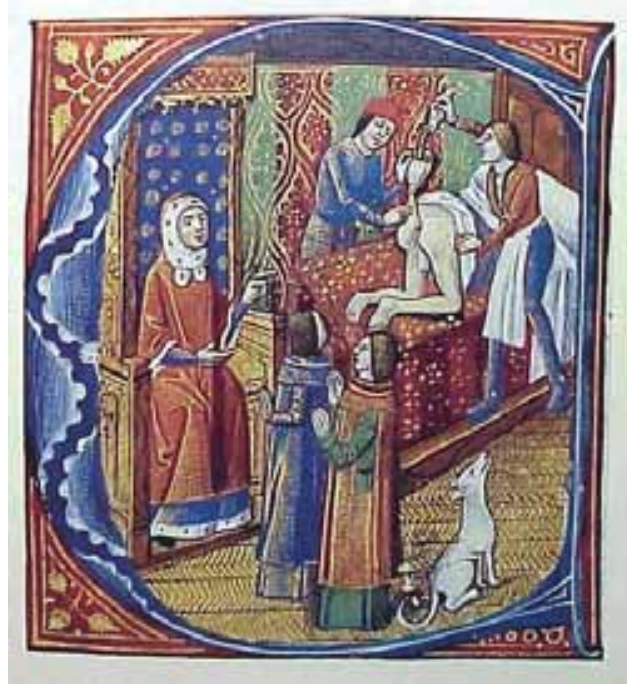

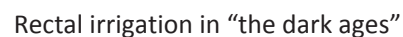




\section{[?]?[?]:?]?:?}

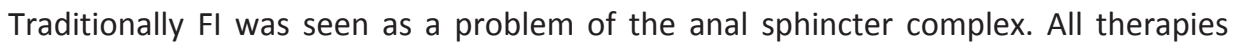

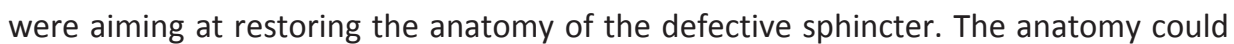

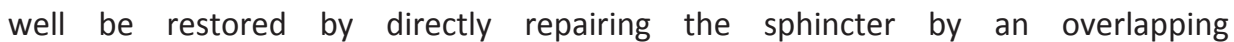

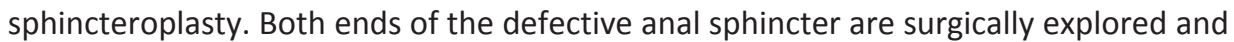

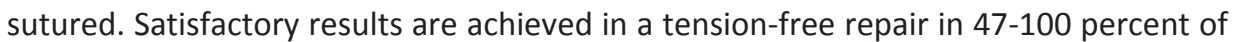

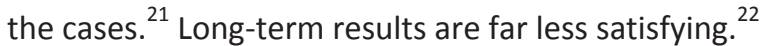

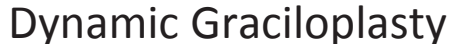

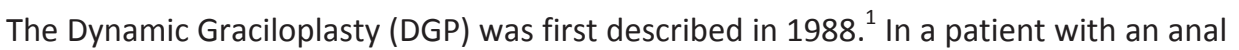

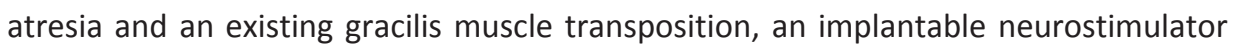

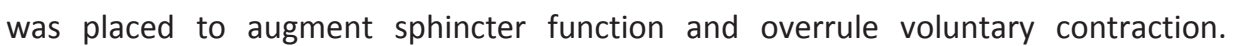

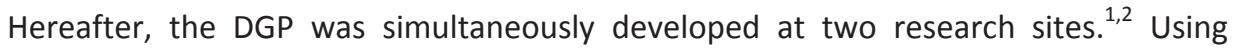

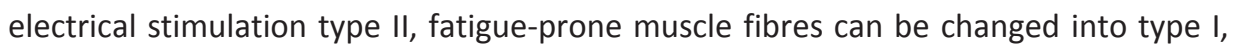

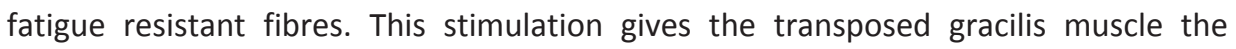

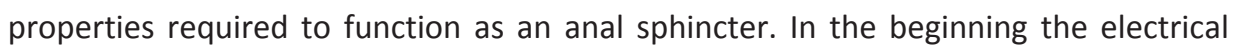

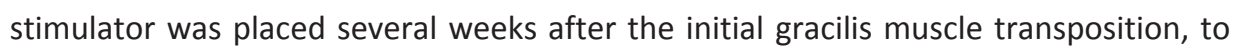

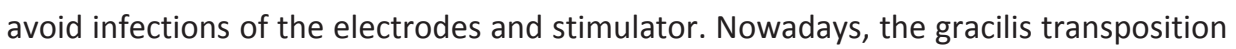

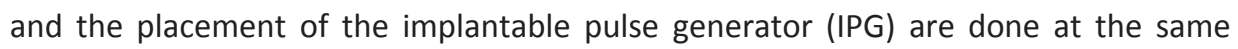

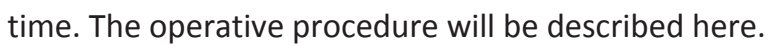

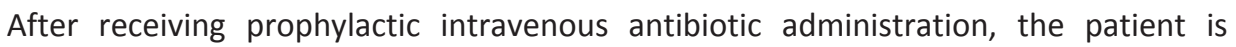

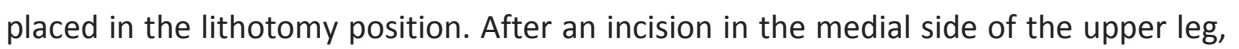

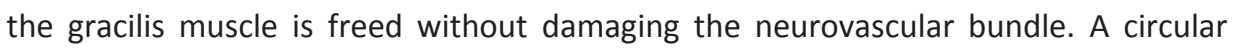

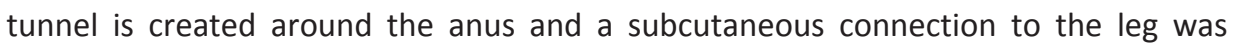

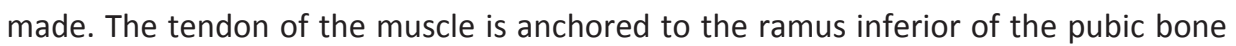

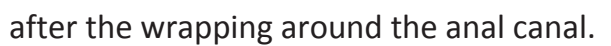

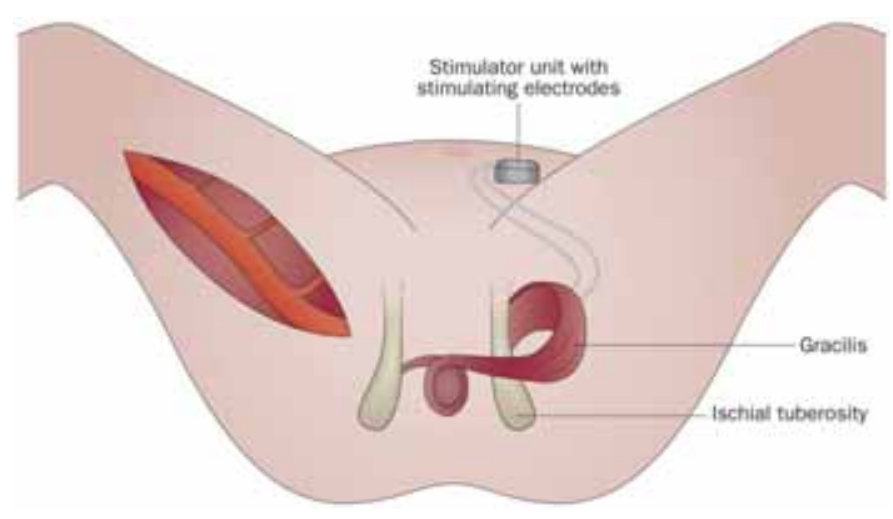




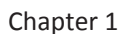

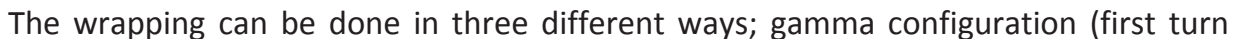

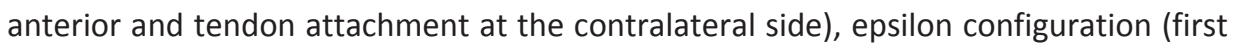

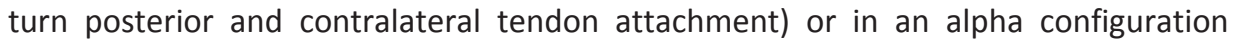

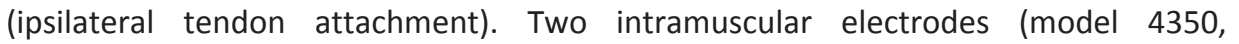

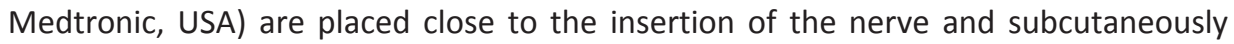

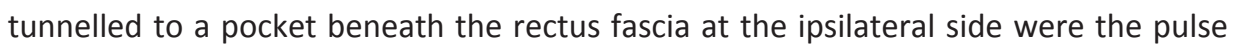

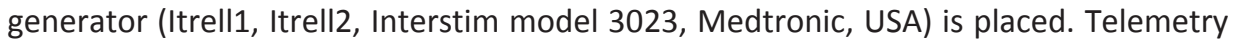

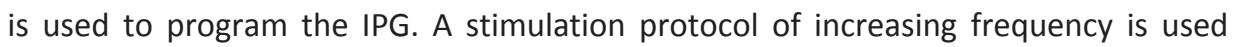

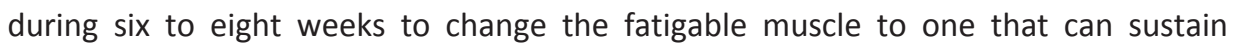

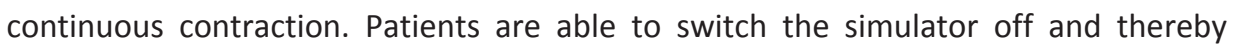

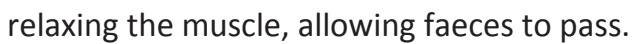

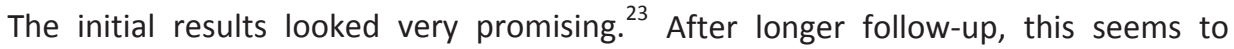

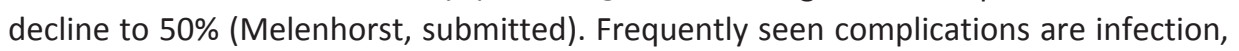

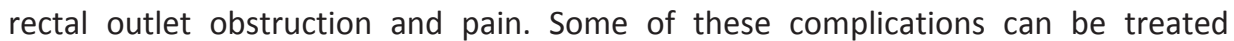

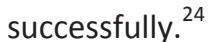

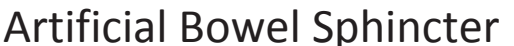

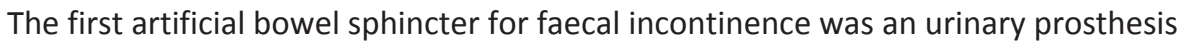

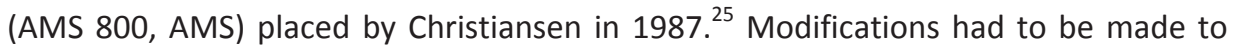

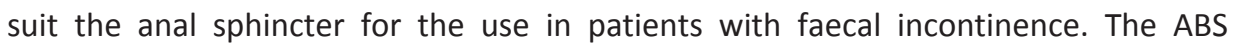

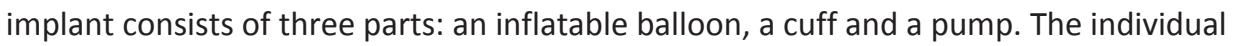

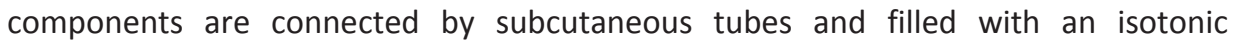

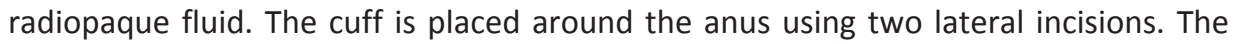

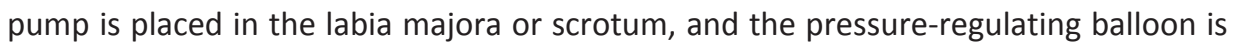

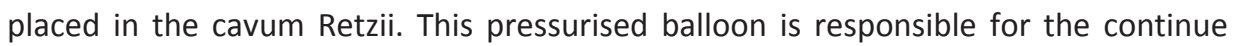

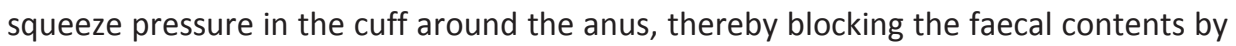

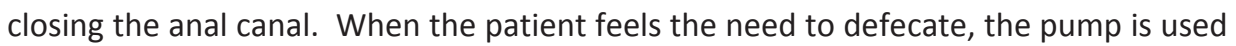

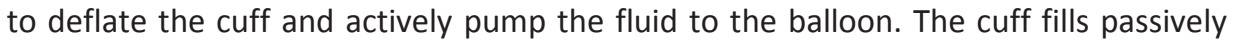

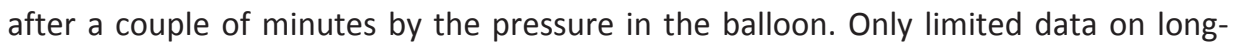

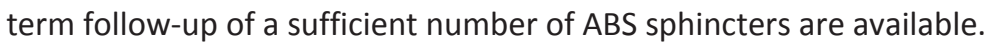

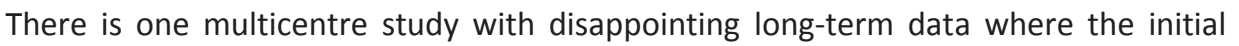

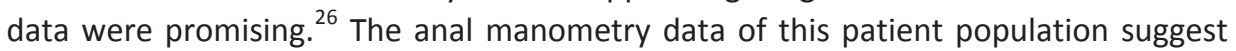

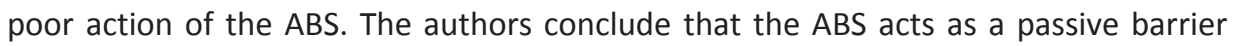

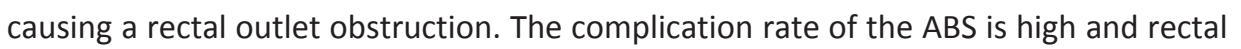

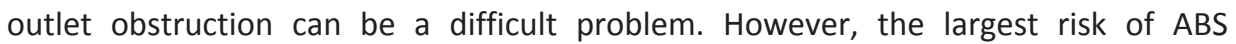

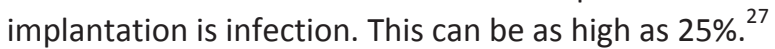




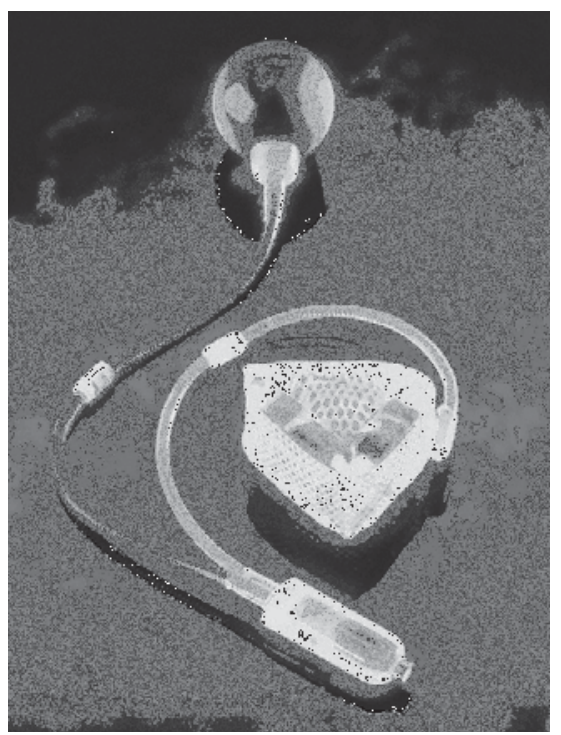

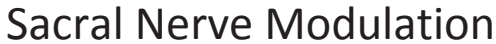

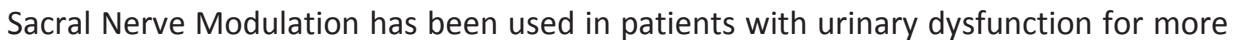

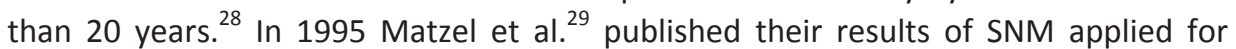

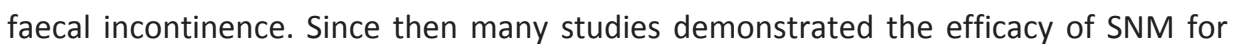

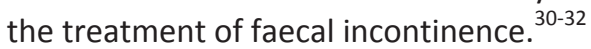

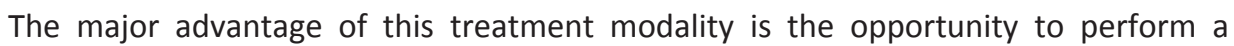

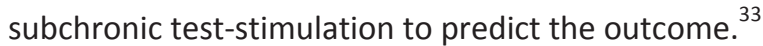

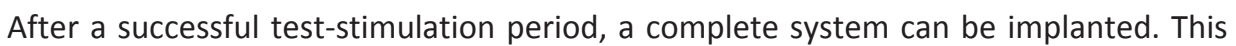

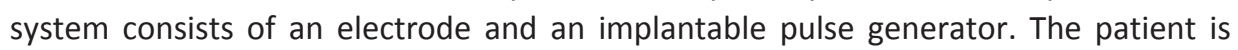

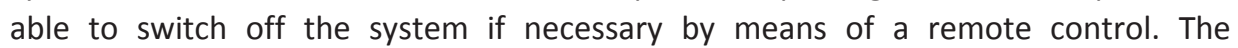

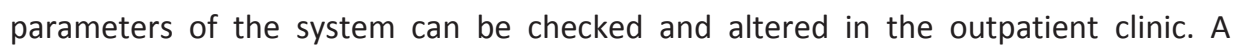

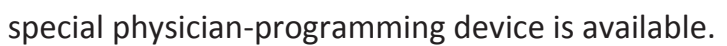

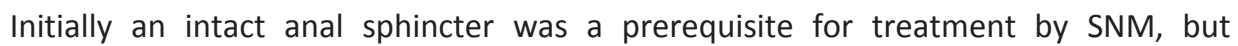

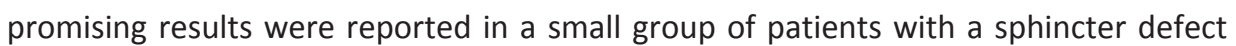

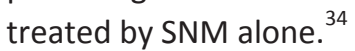

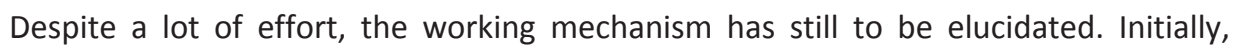

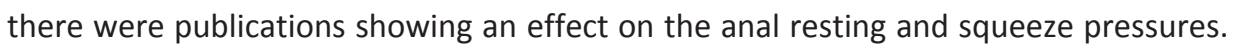

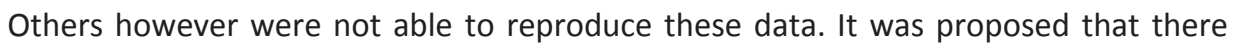

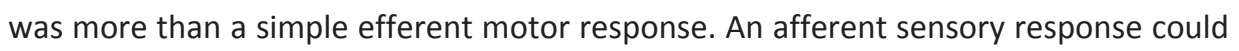

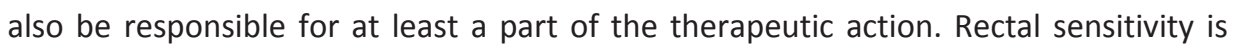

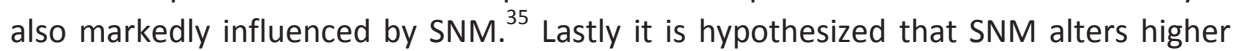

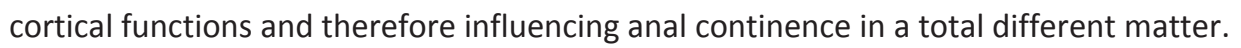

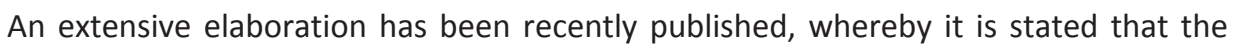




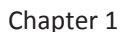

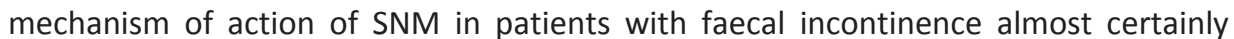

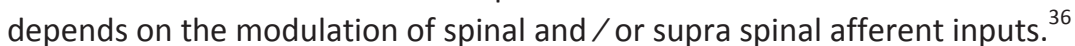

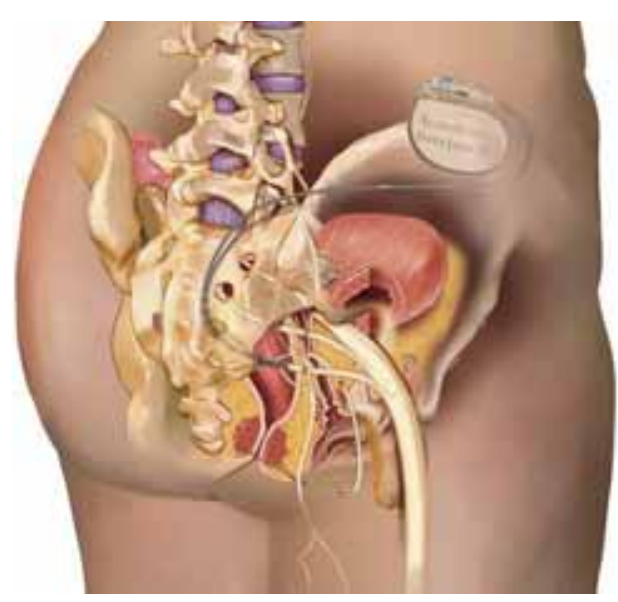

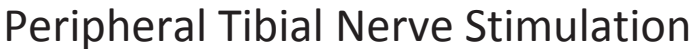

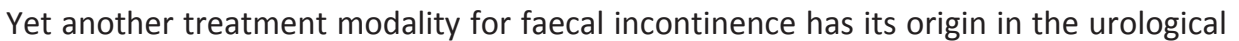

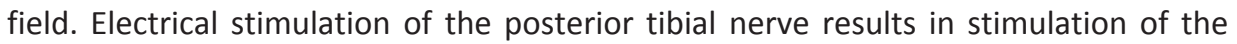

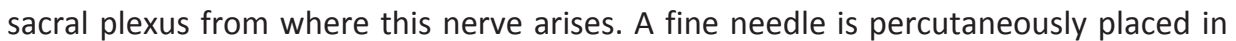

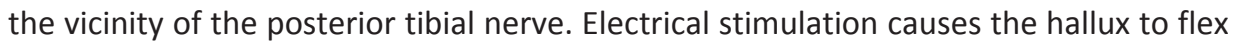

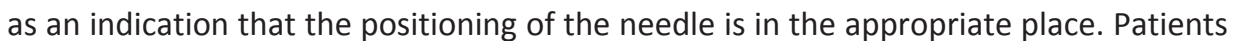

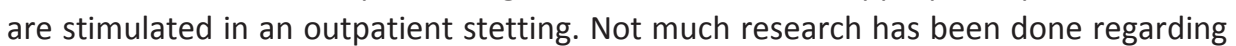

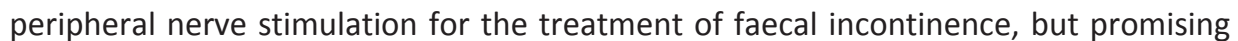

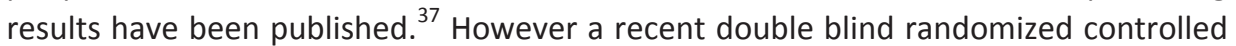

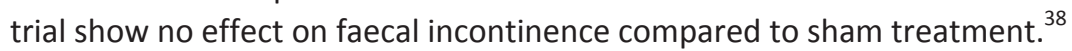

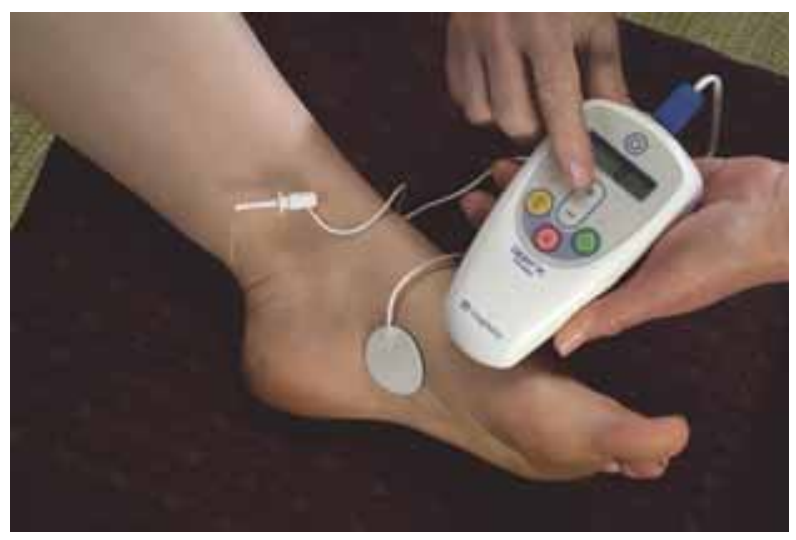




\section{??]国?]?]? ?}

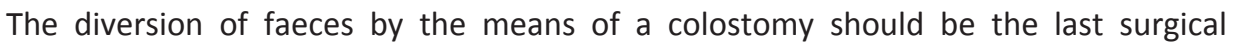
[

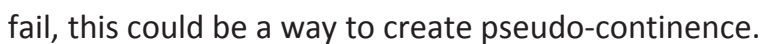

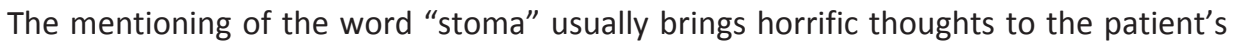

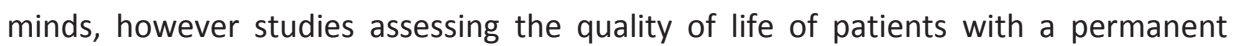

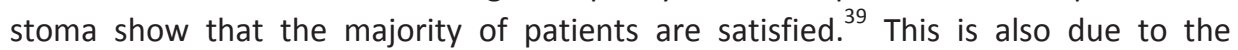

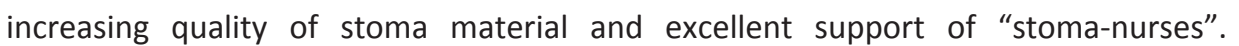

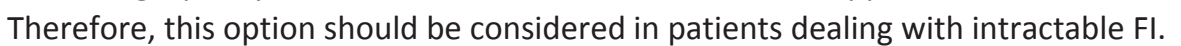

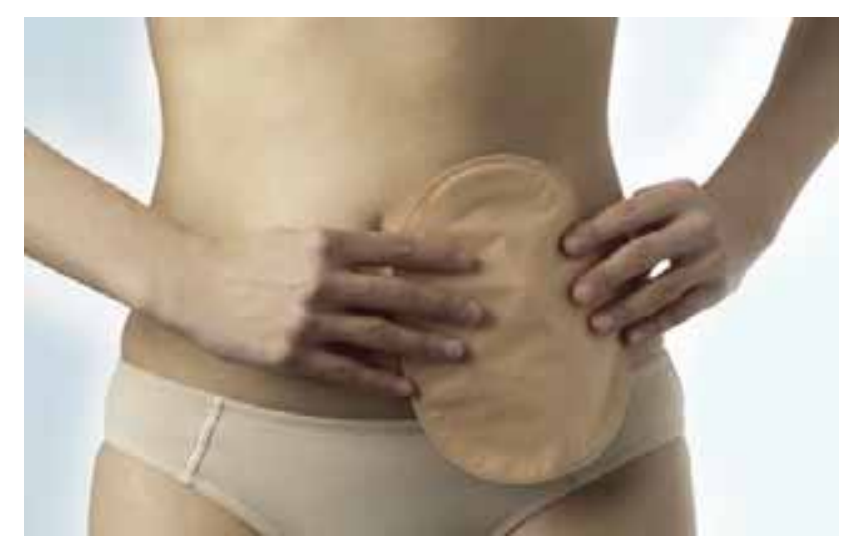

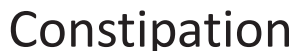

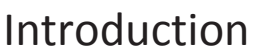

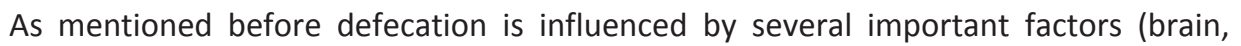

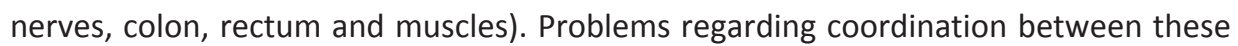

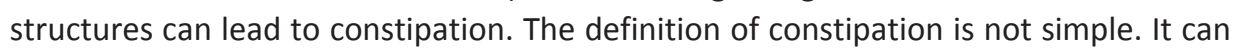

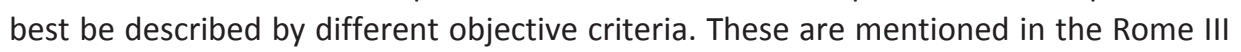
[?] ? 


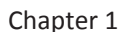

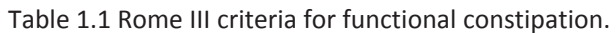

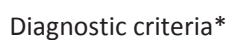

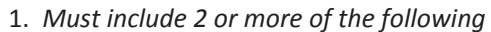

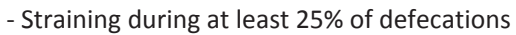

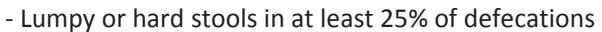

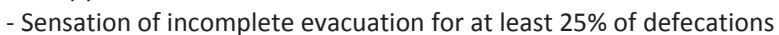

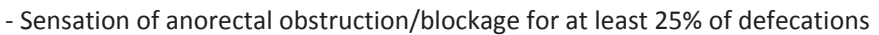

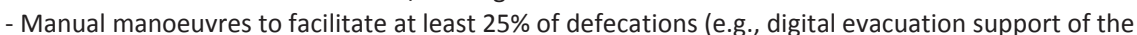

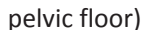

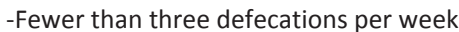

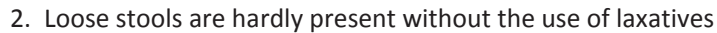

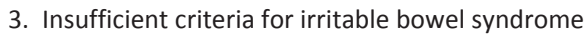

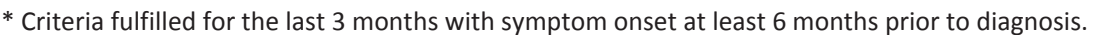

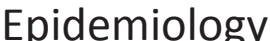

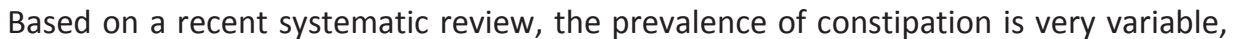

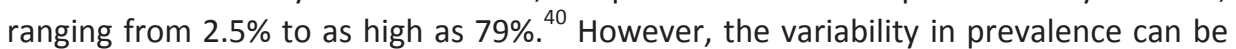

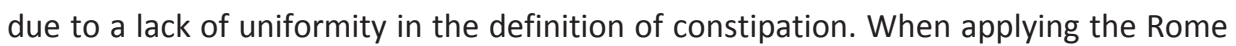

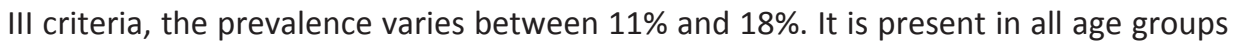

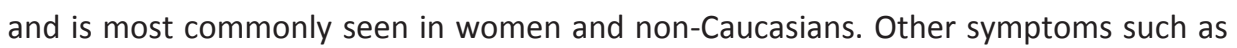

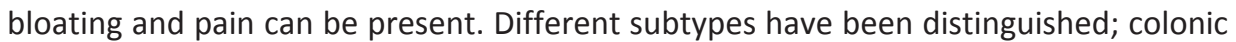

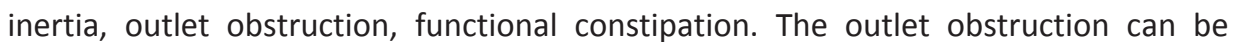

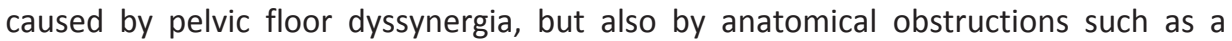

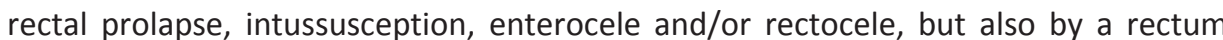

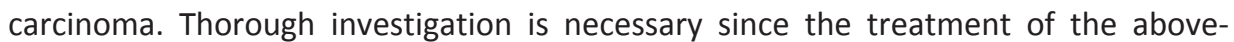

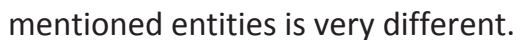

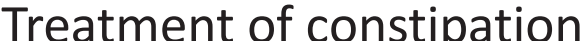

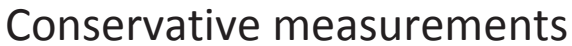

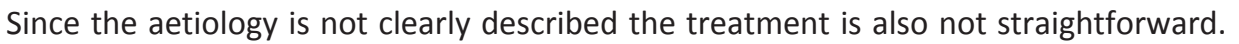

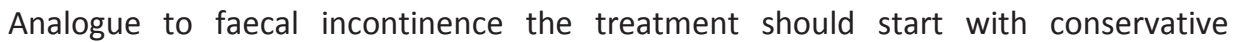

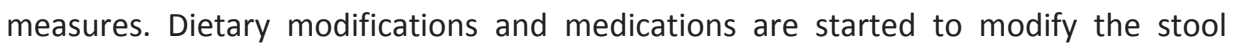

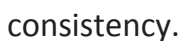

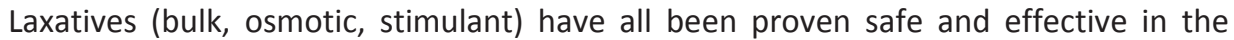

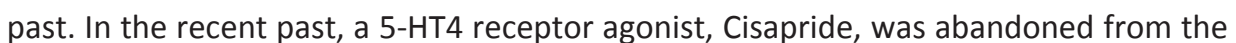

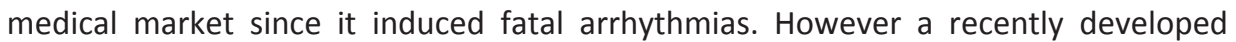

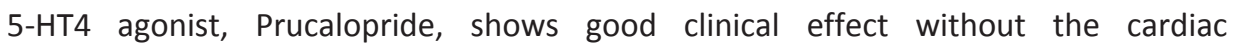

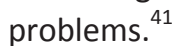




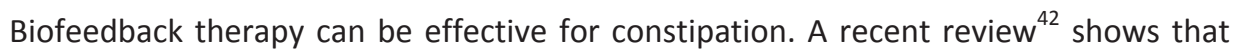

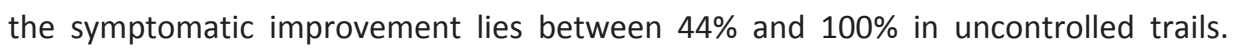

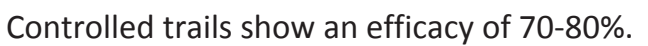

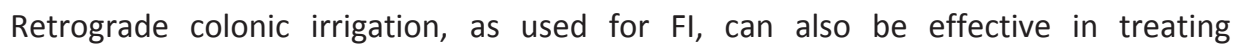

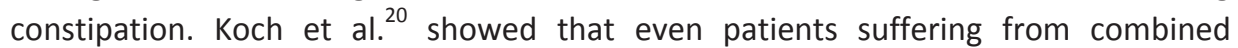

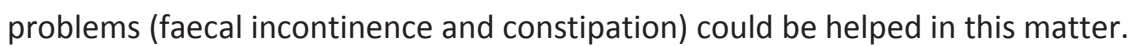

\section{[?]?]?[?]?]?}

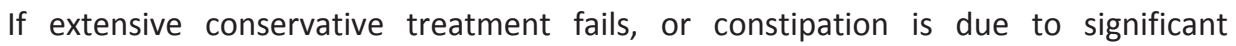

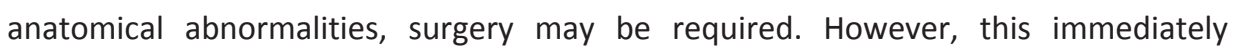

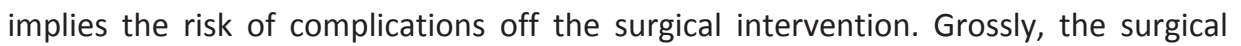

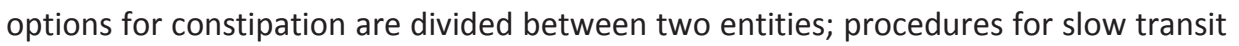

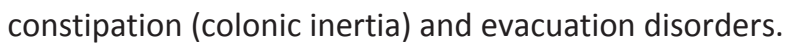

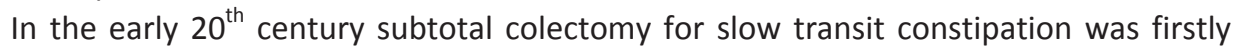

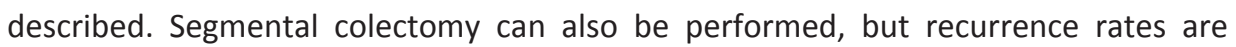

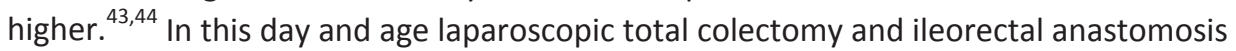

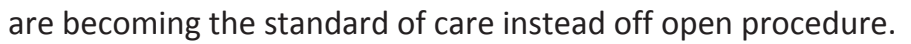

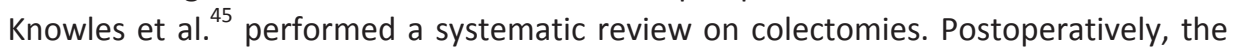

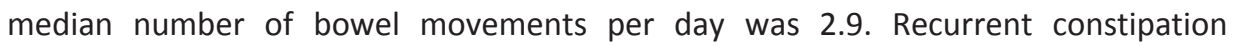

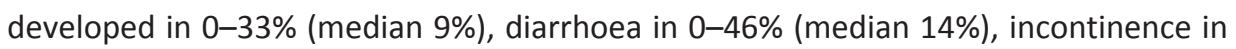

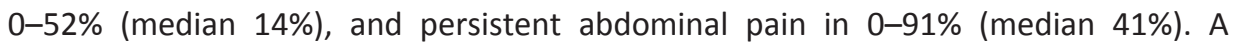

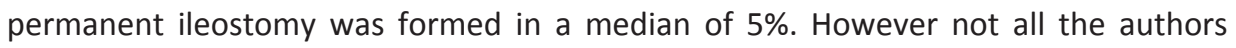

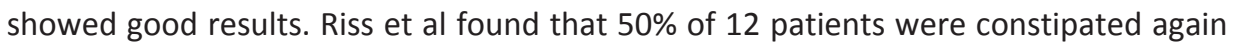

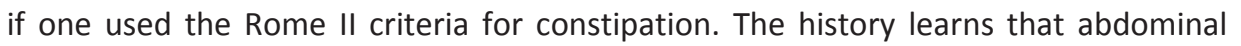

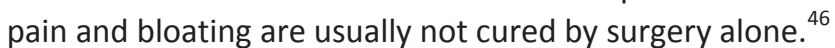

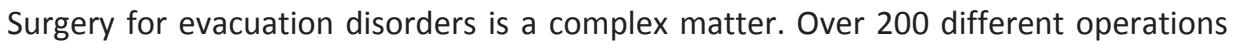

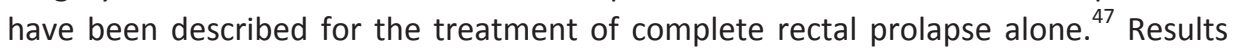

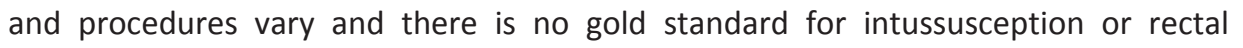

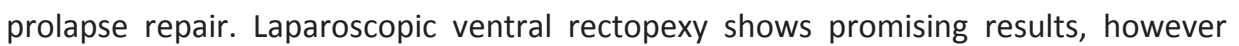

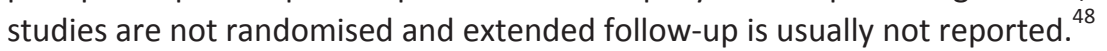

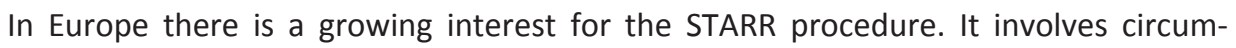

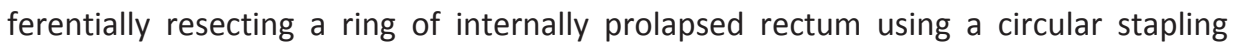

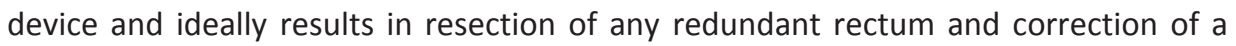

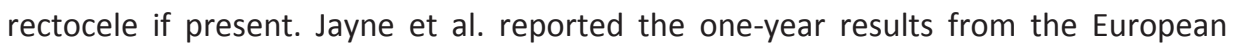

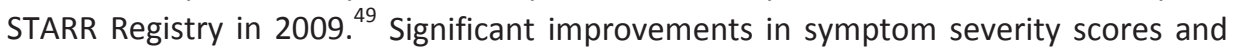

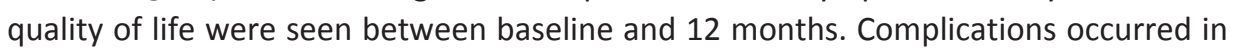

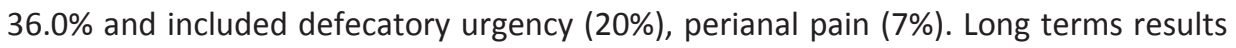

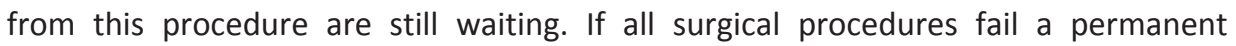

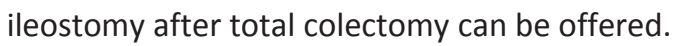




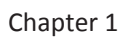

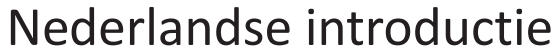

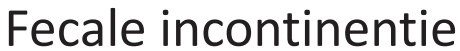

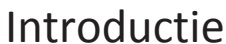

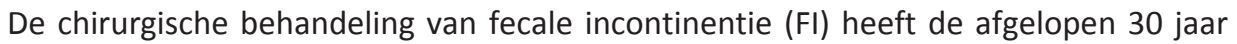

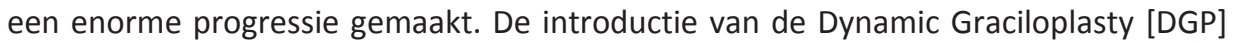

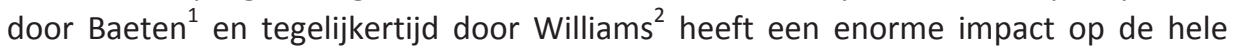

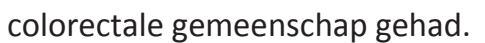

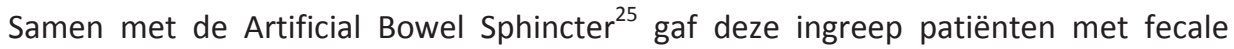

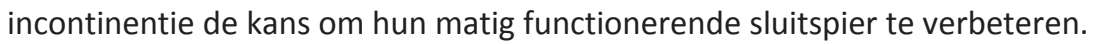

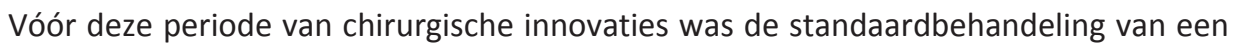

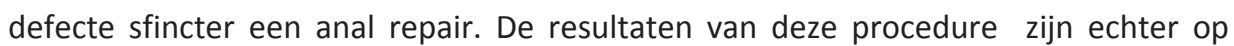

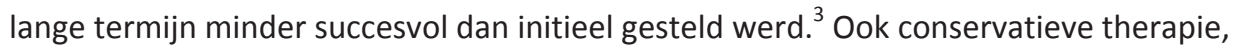

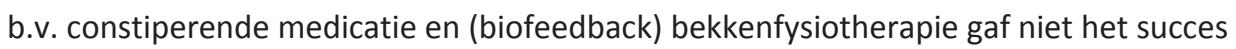

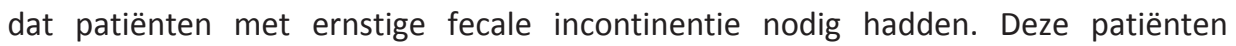

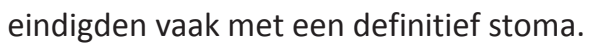

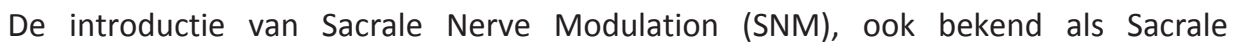

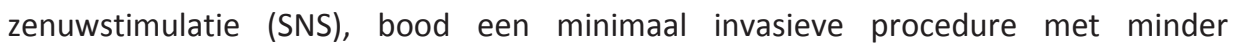

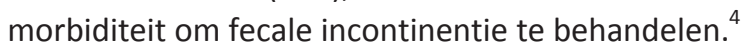

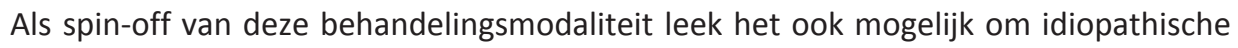

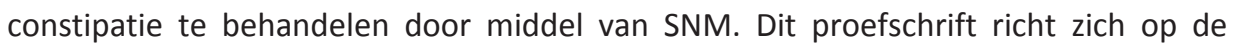

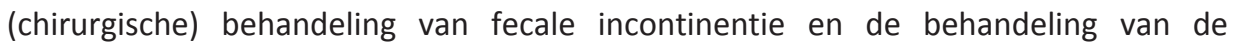

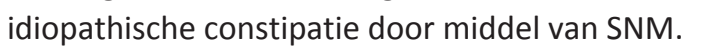

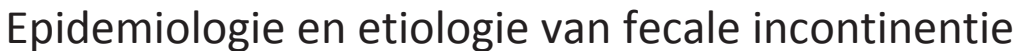

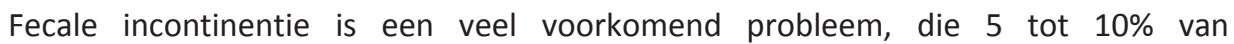

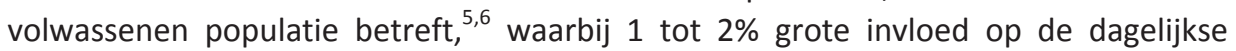

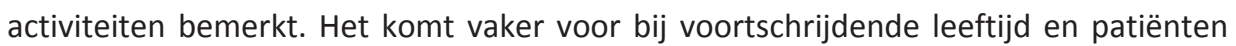

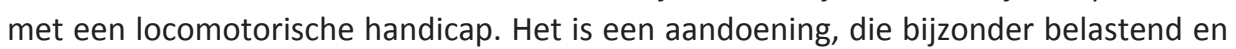

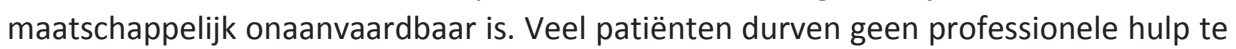

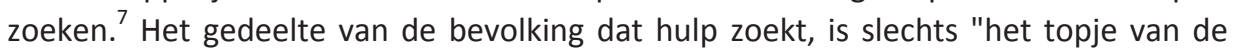
[5

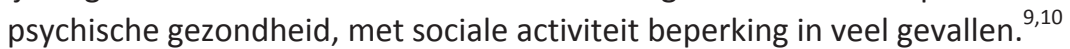

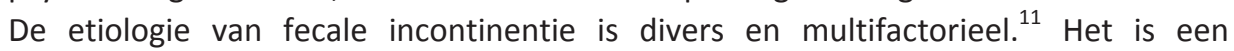

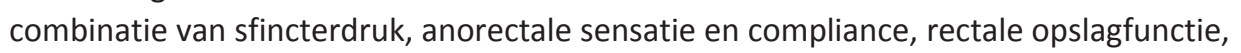

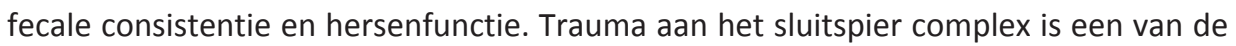

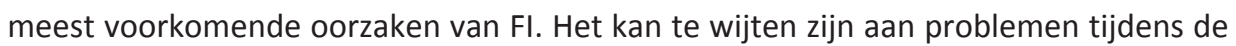

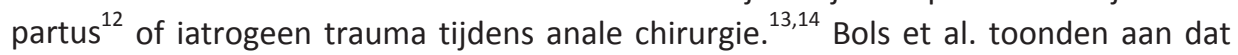




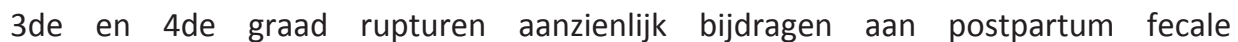

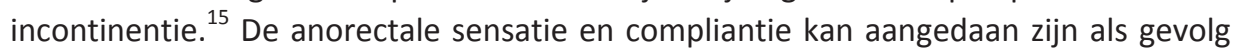

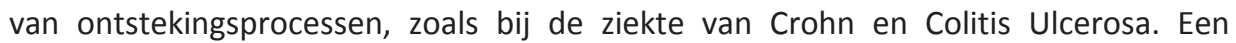

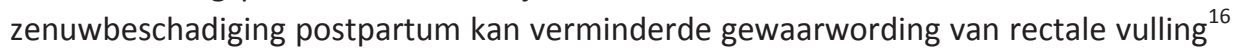

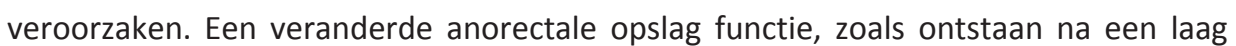

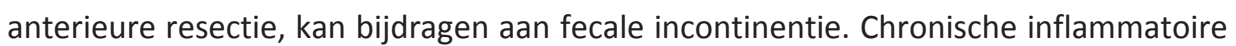

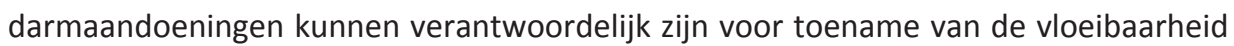

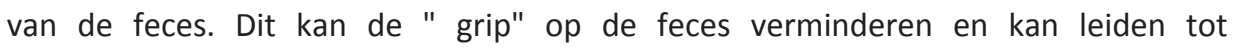

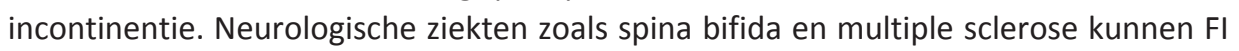

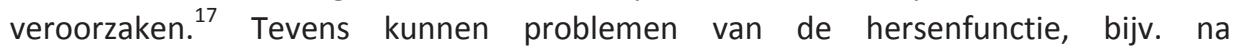

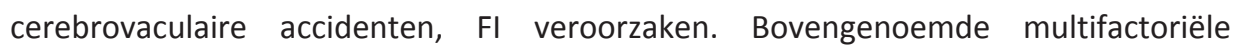

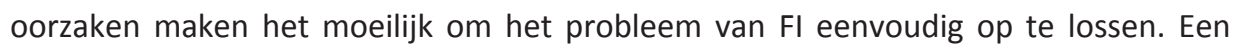

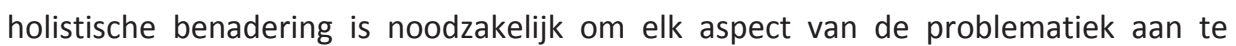

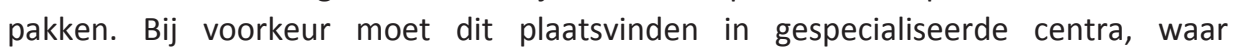

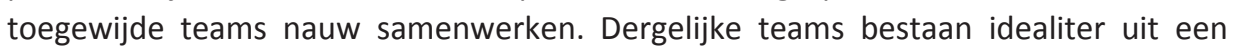

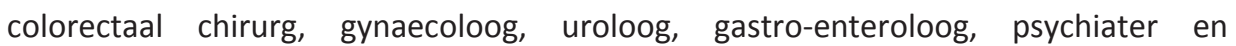

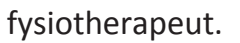

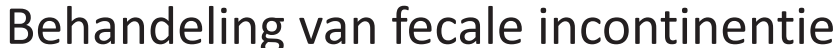

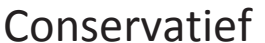

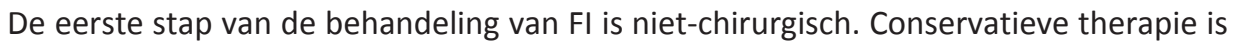

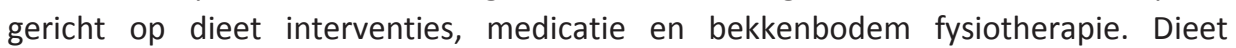

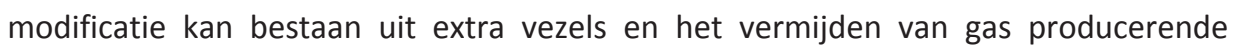

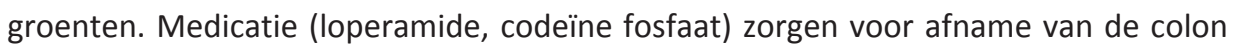

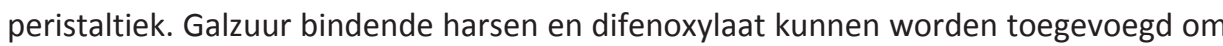

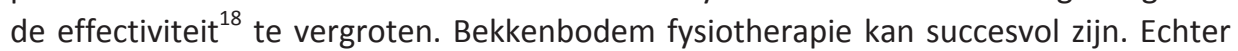

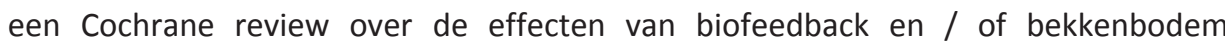

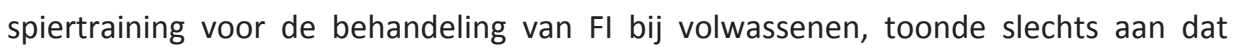

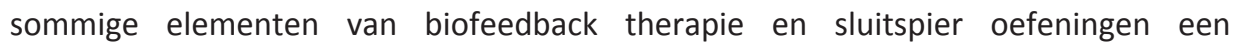

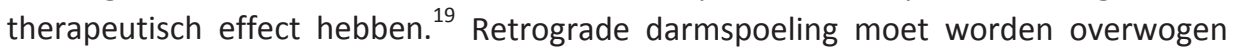

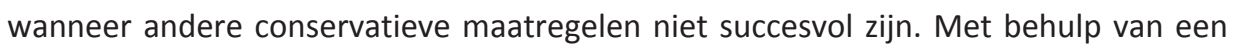

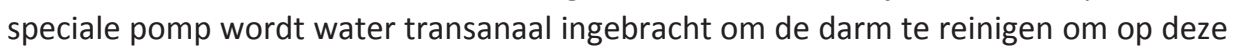

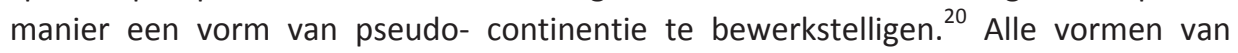

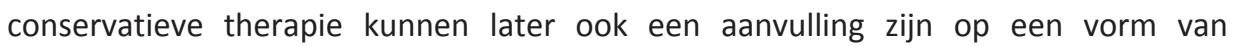

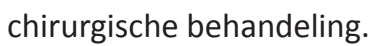




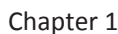

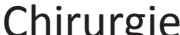

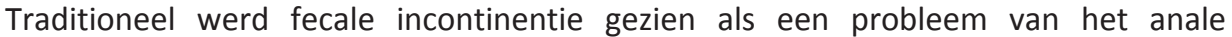

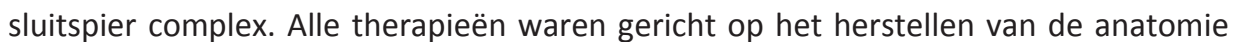

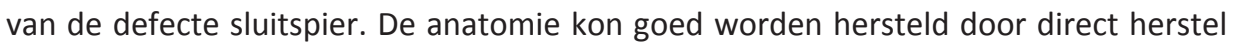

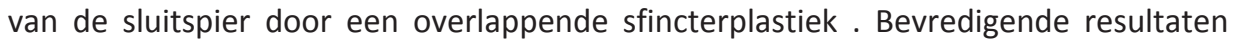

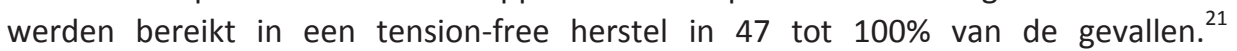

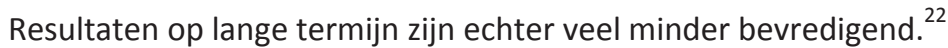

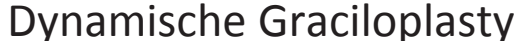

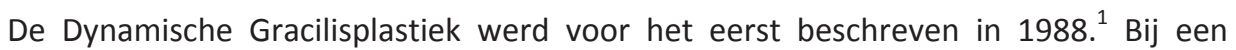

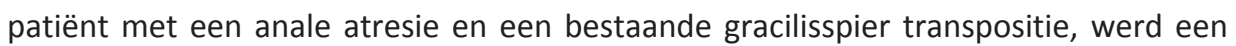

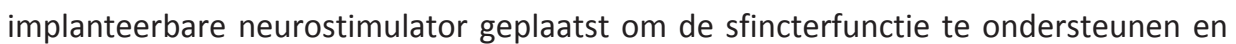

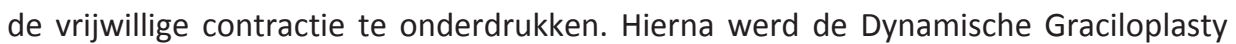

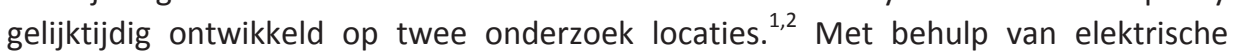

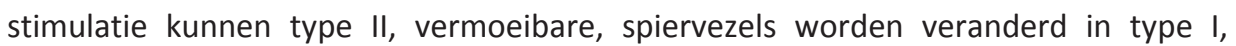

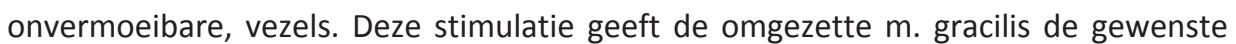

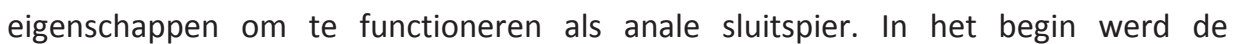

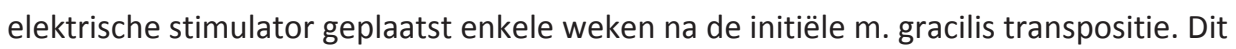

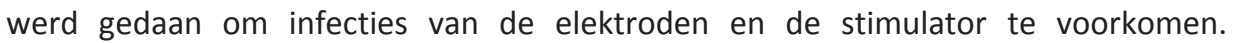

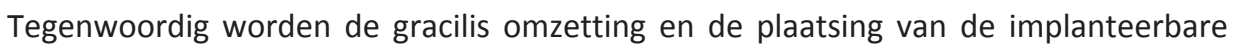

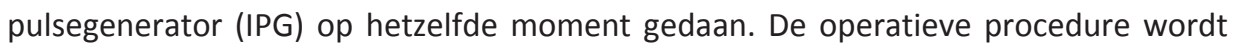

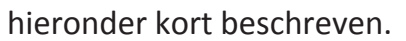

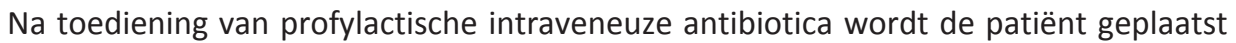

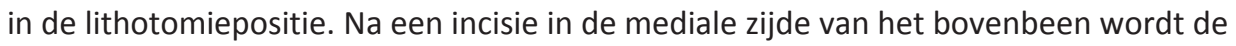

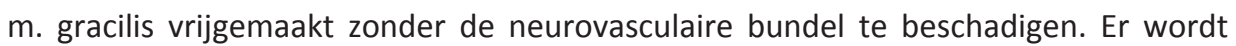

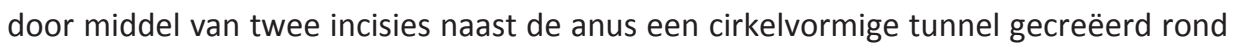

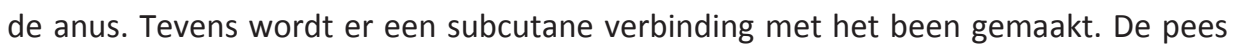

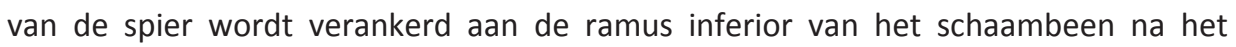

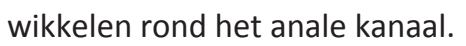

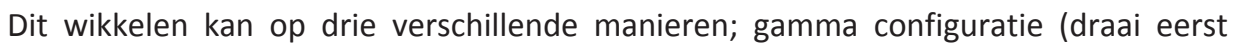

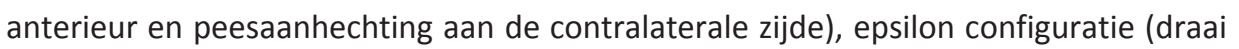

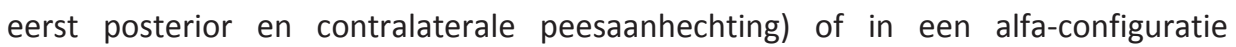

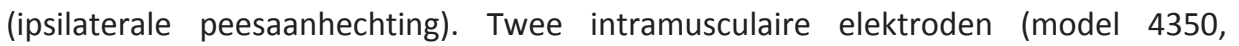

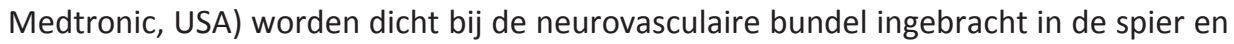

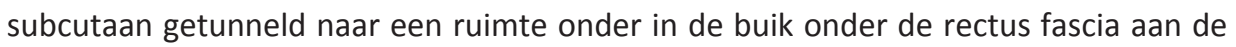

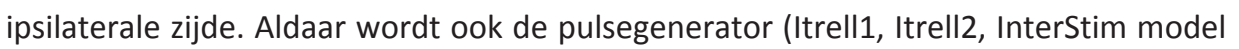

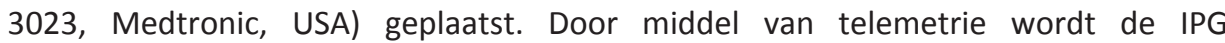

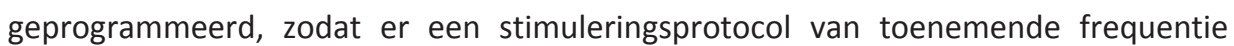

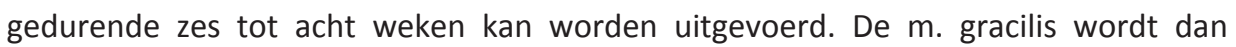




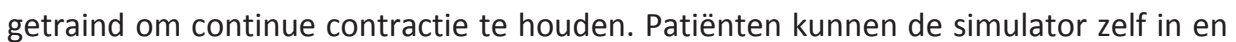

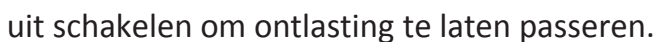

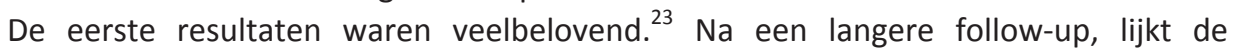

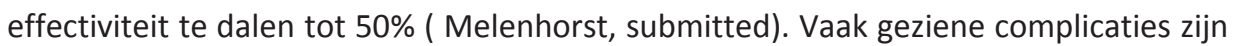

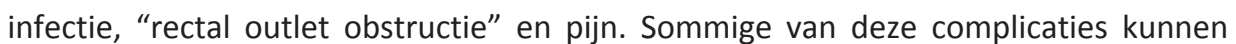

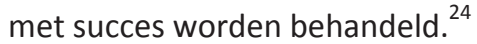

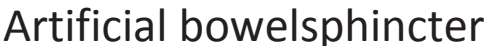

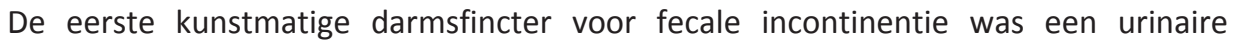

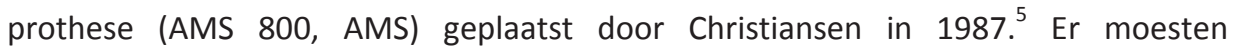

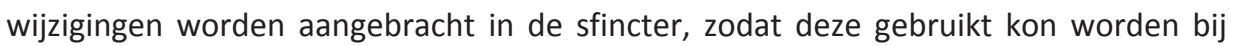

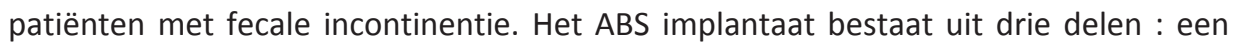

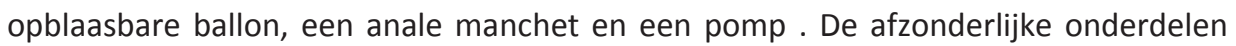

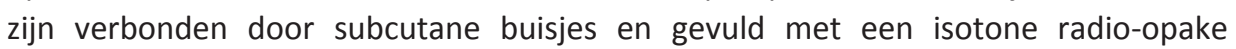

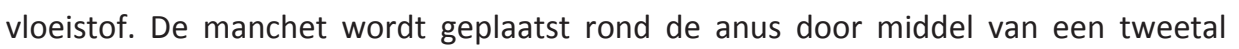

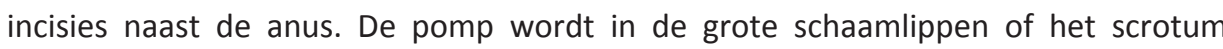

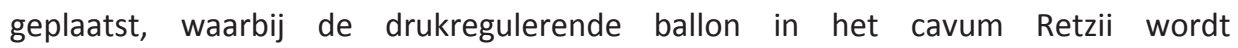

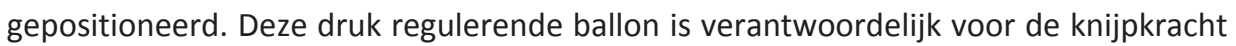

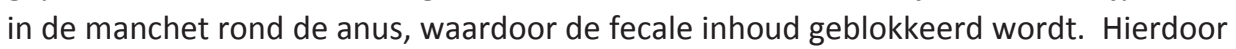

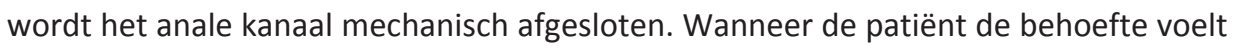

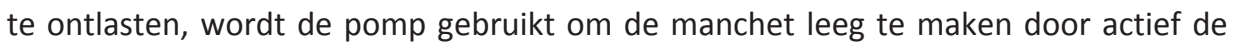

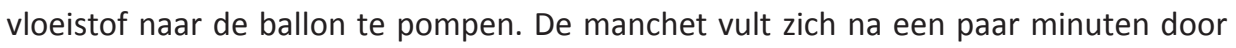

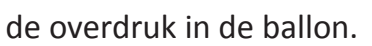

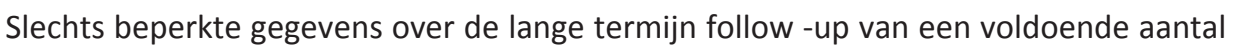

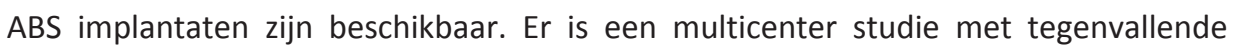

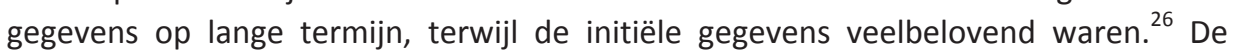

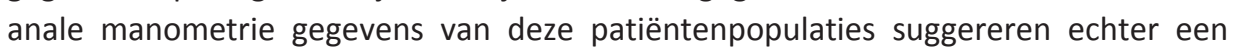

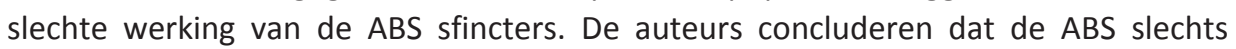

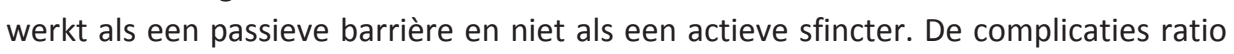

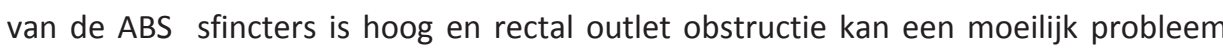

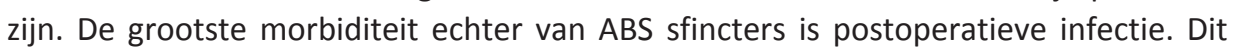

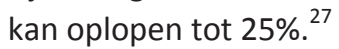

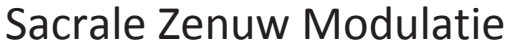

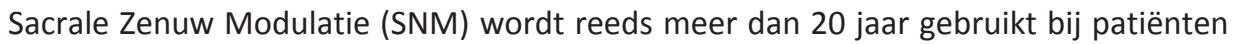

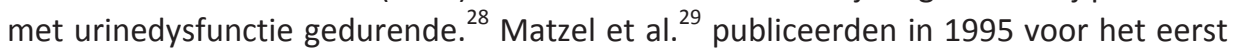

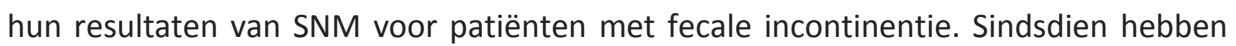

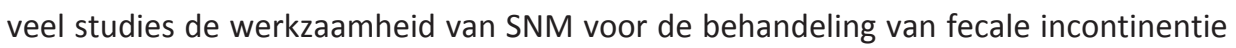

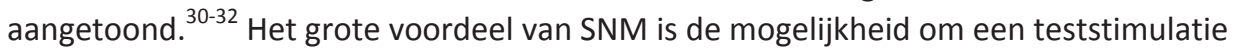

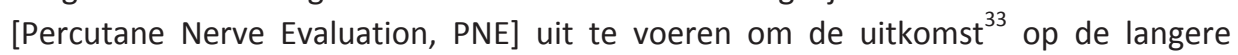




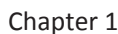

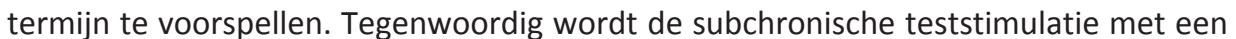

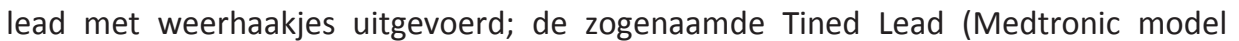

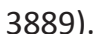

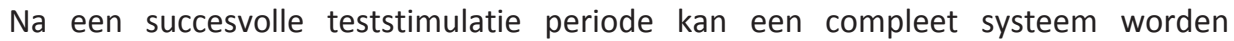

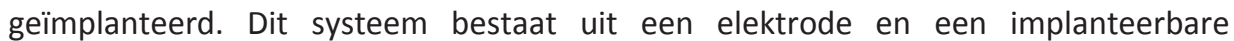

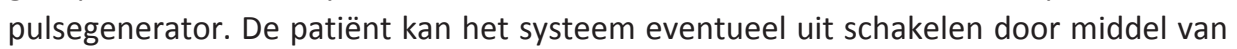

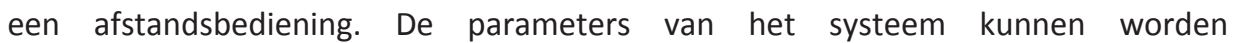

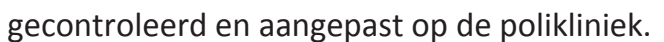

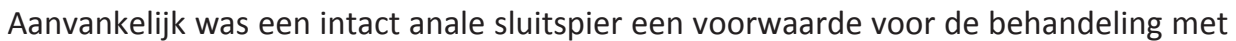

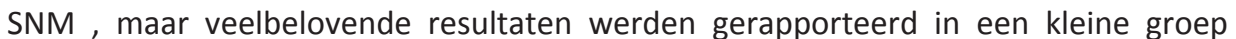

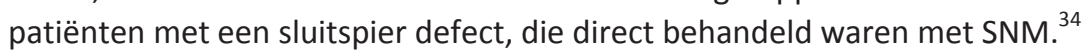

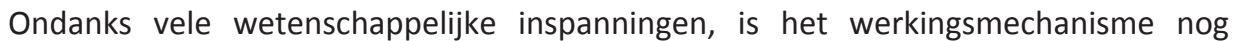

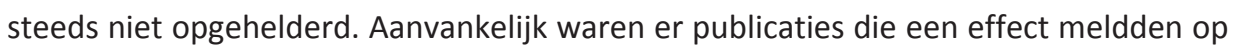

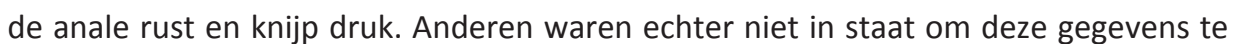

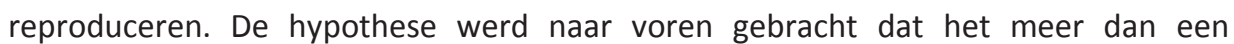

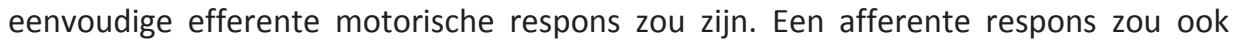

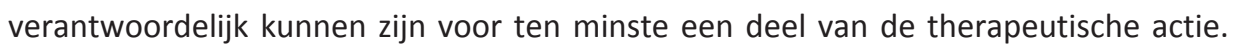

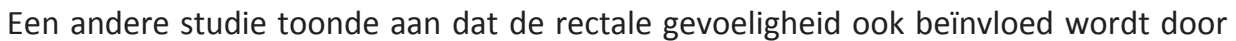

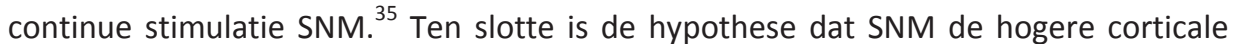

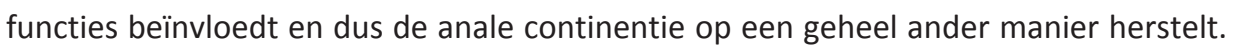

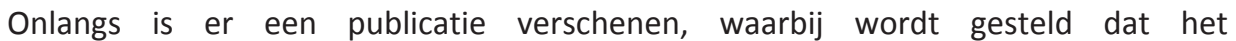

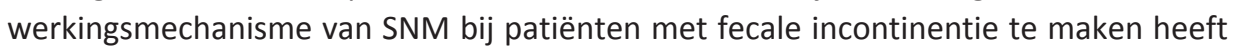

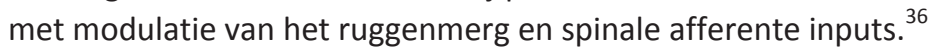

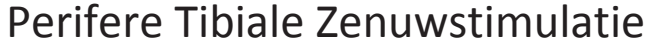

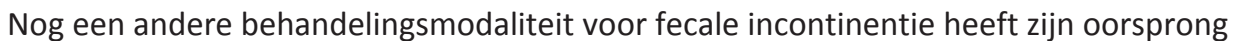

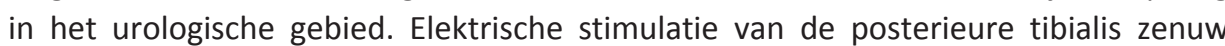

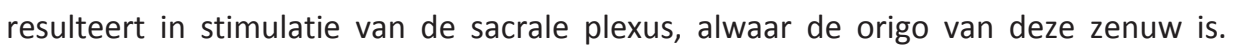

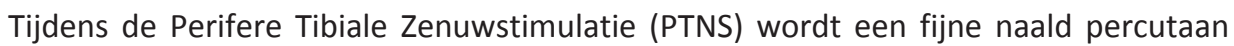

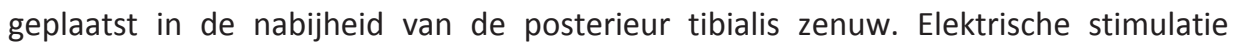

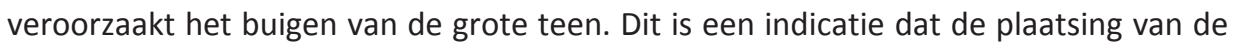

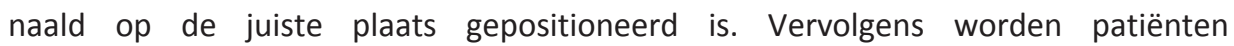

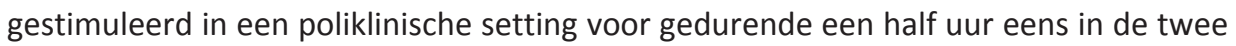

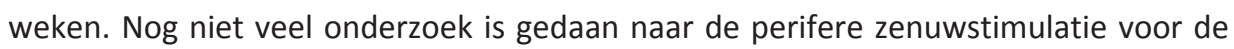

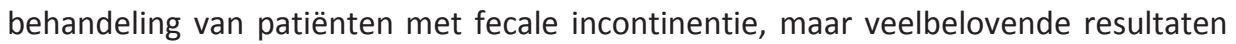

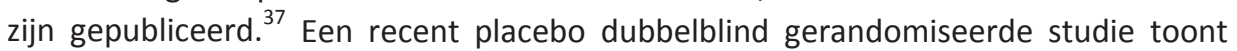

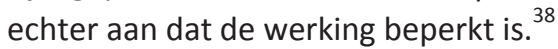




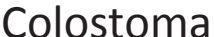

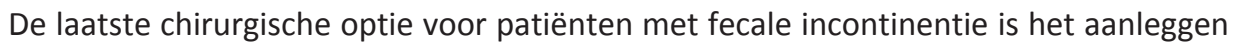

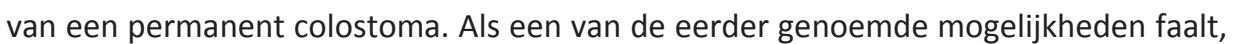

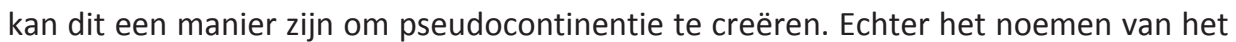

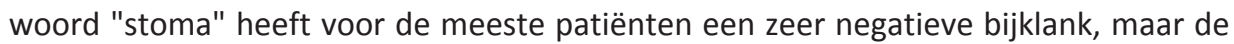

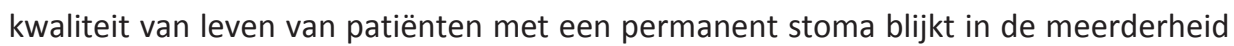

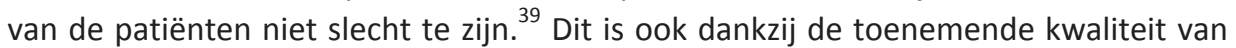

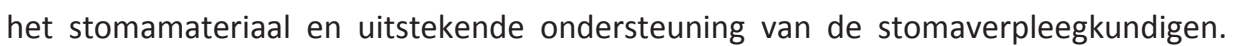

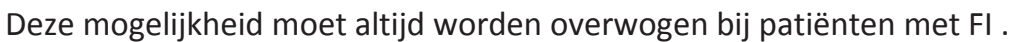

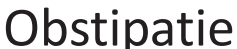

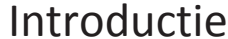

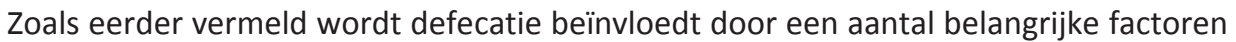

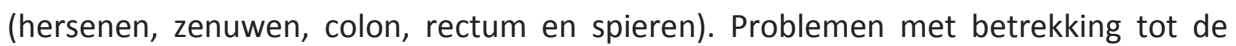

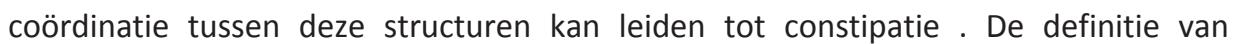

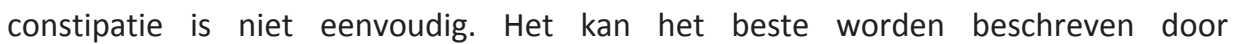

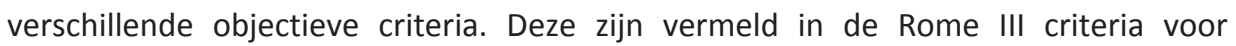

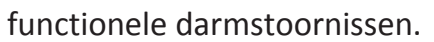

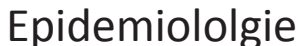

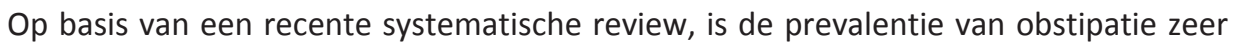

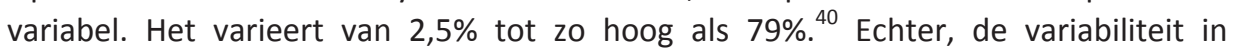

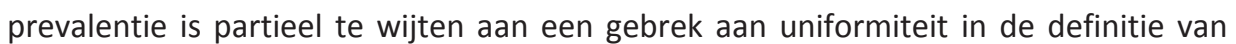

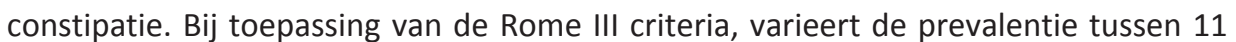

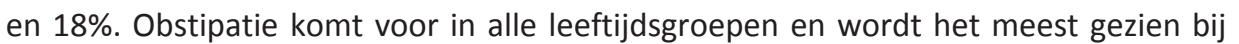

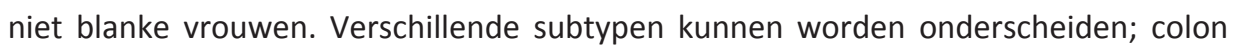

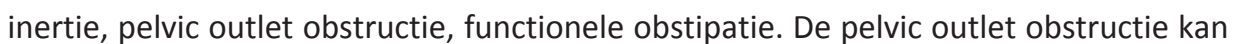

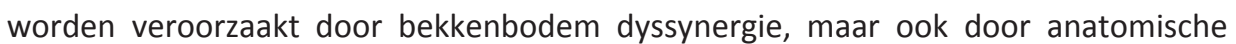

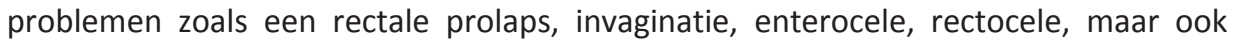

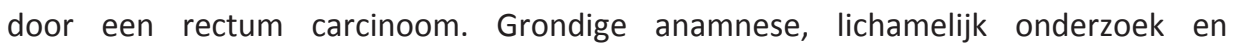

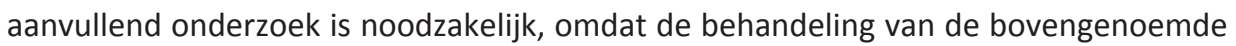

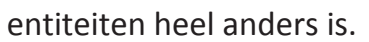




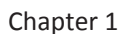

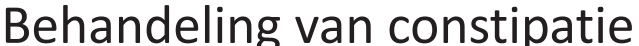

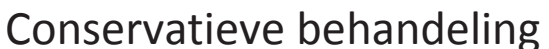

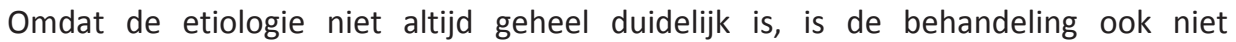

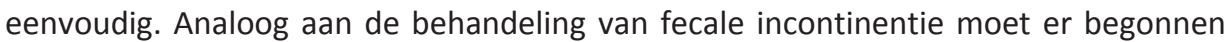

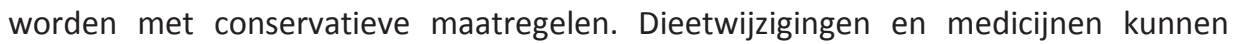

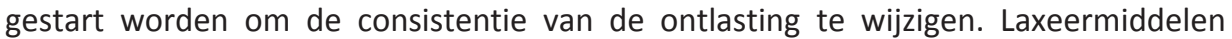

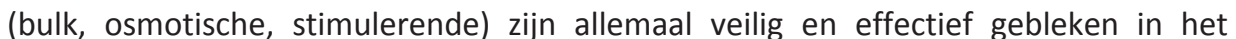

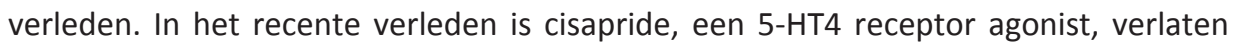

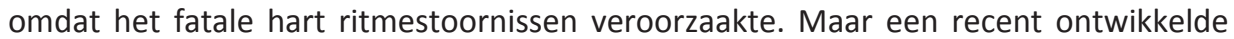

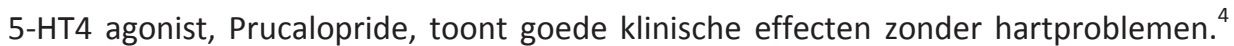

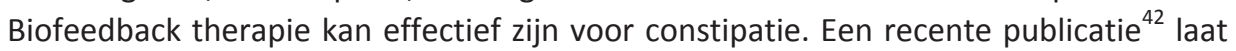

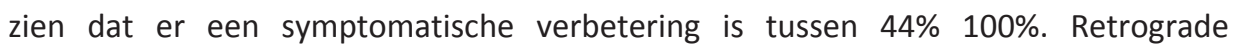

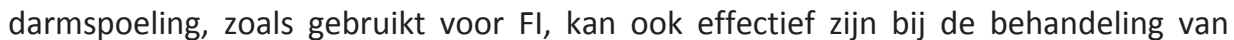

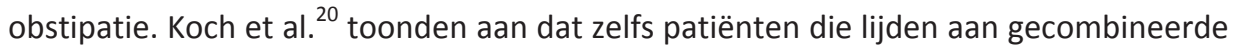

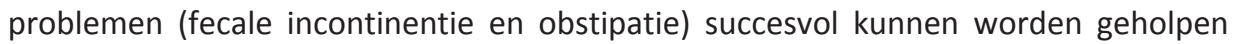

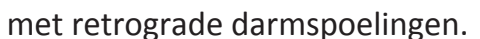

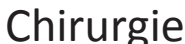

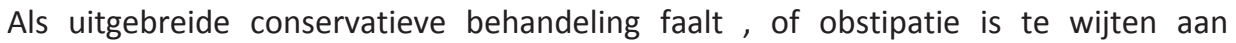

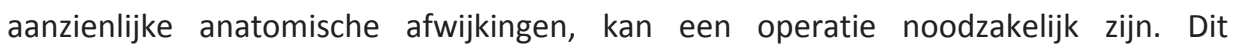

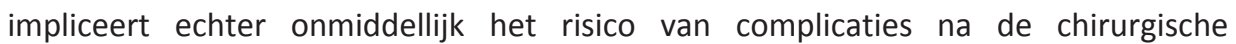

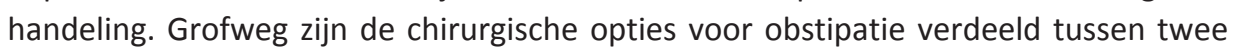

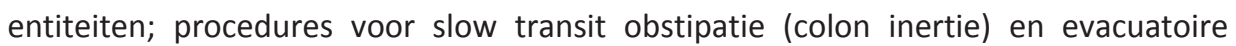

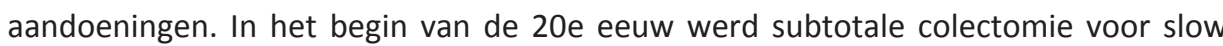

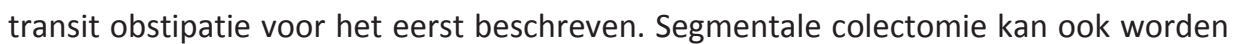

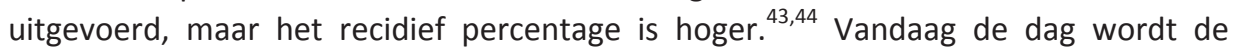

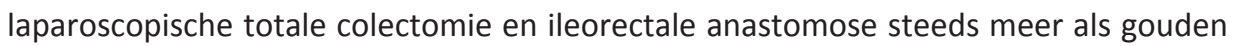

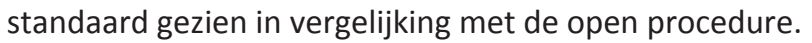

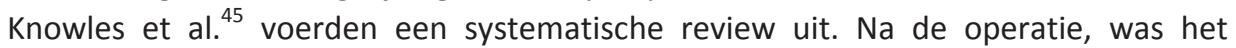

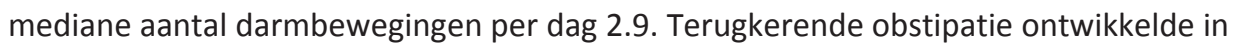

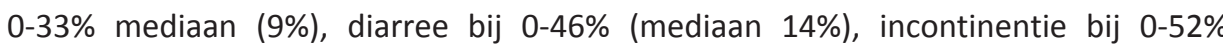

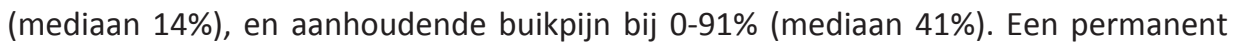

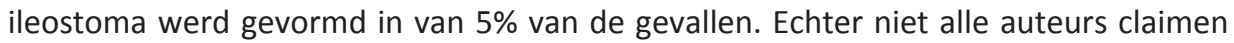

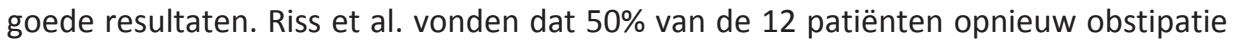

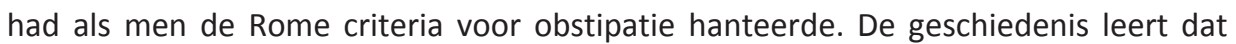

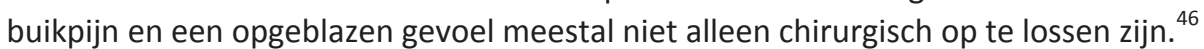

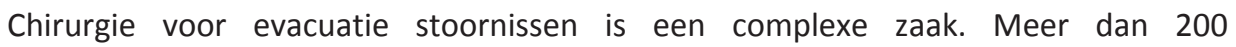

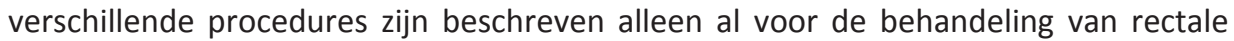

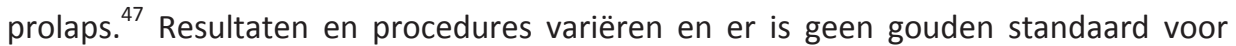




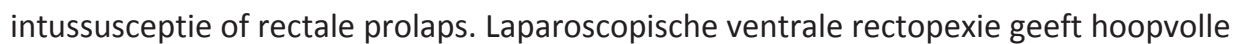

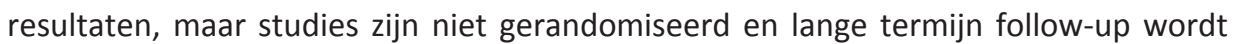

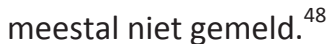

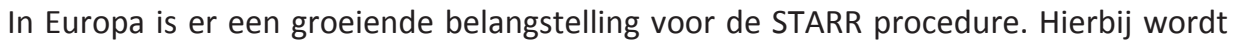

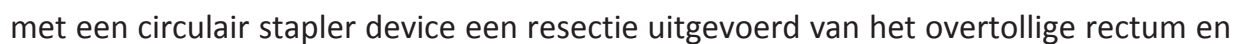

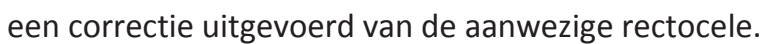

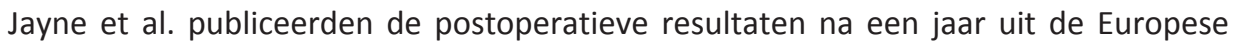

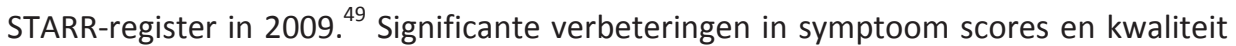

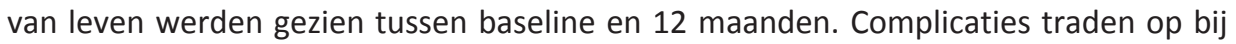

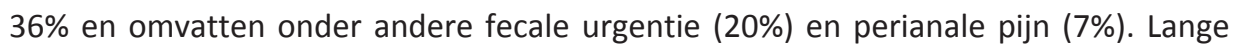
ब⿴囗大

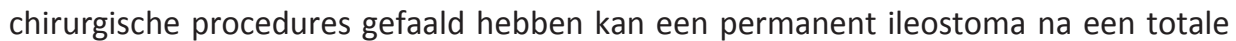

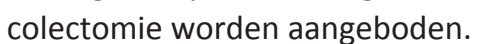




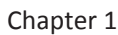

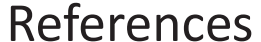

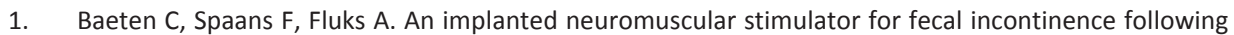

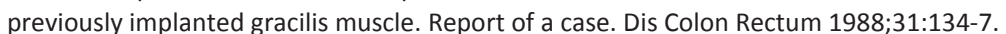

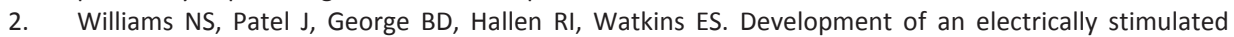

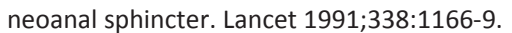

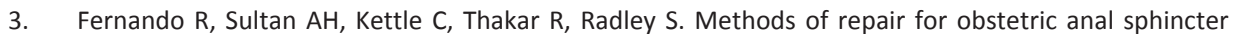

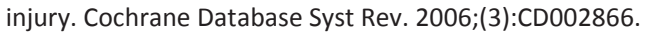

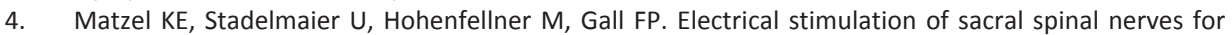

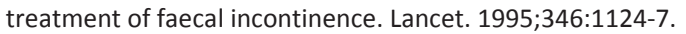

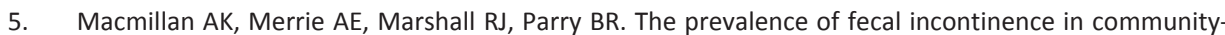

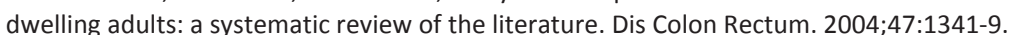

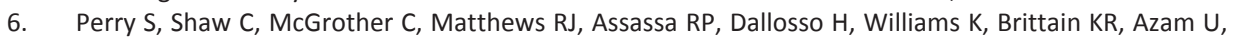

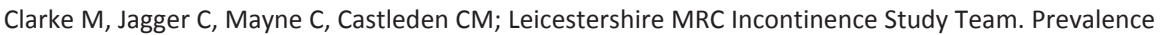

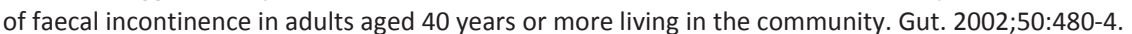

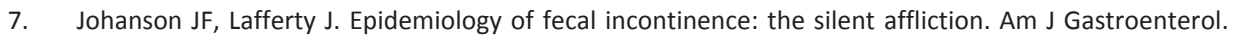

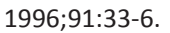

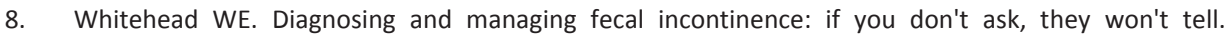

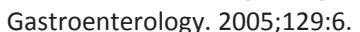

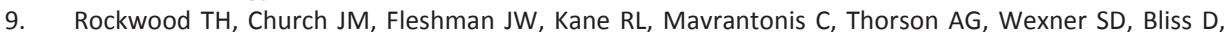

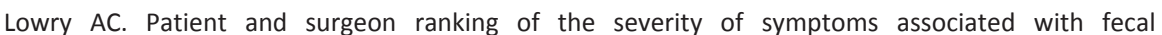

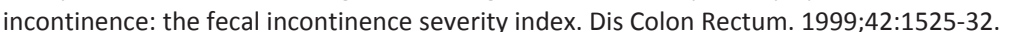

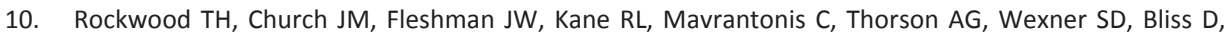

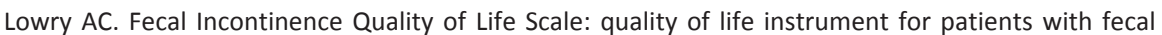

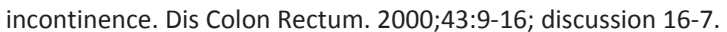

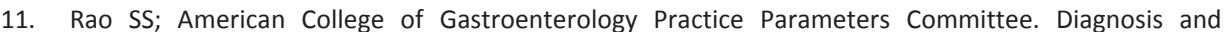

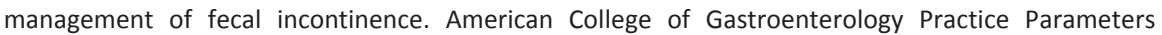

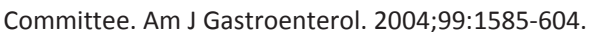

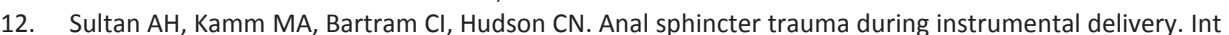

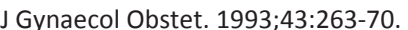

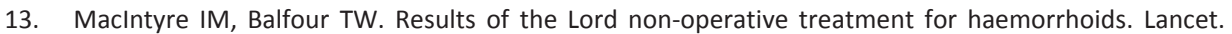

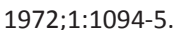

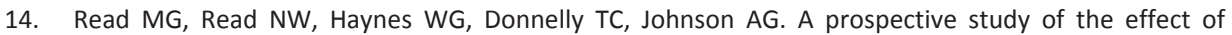

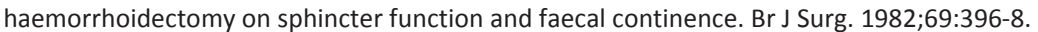

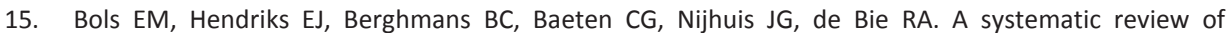

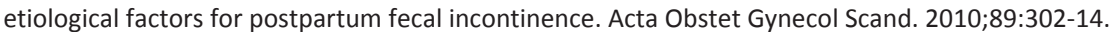

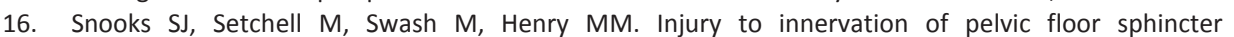

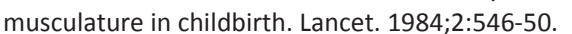

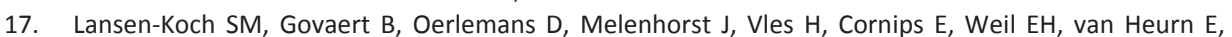

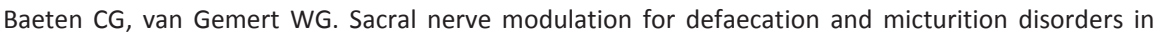

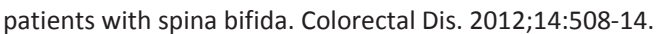

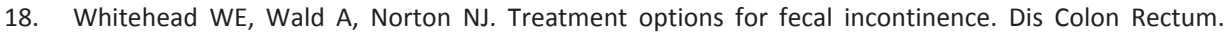

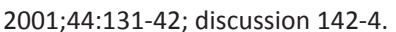

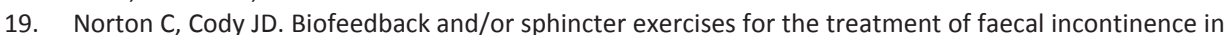

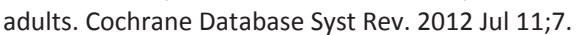

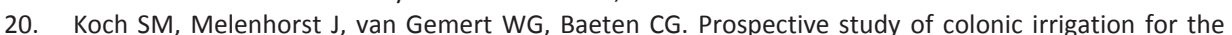

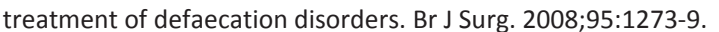

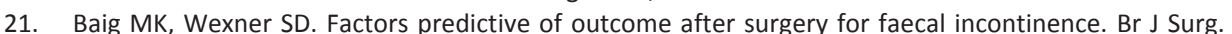

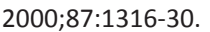

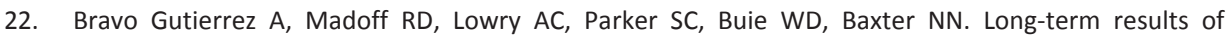

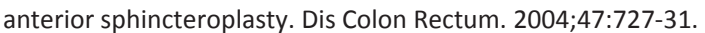




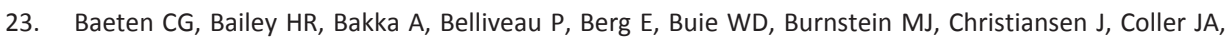

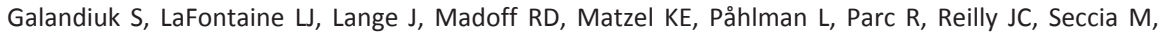

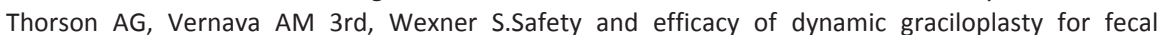

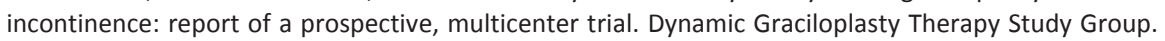

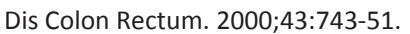

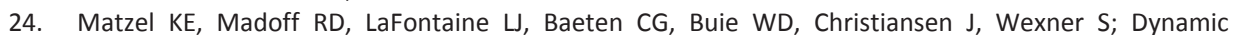

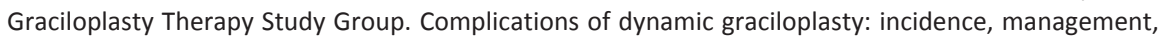

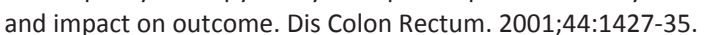

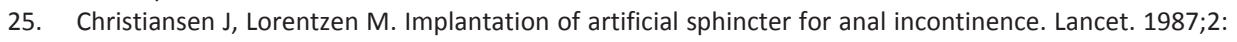
???:?? ?

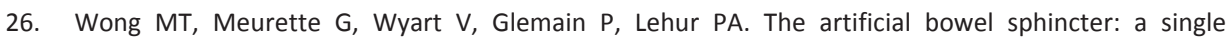

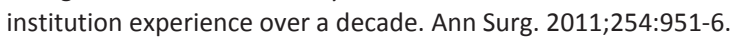

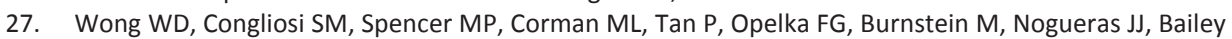

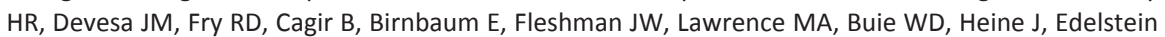

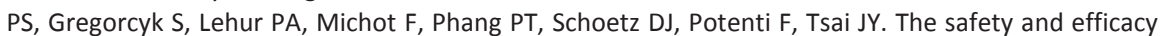

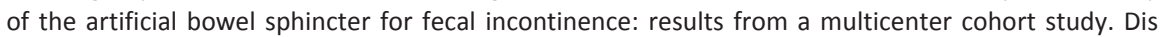

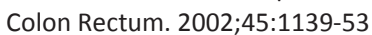

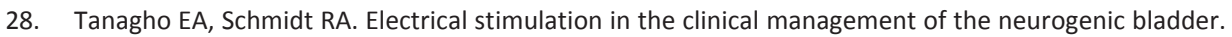

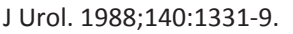

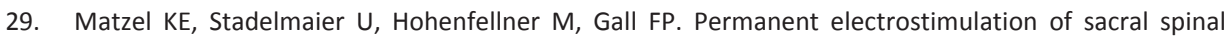

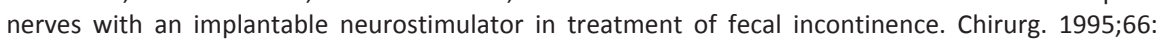
??]-??

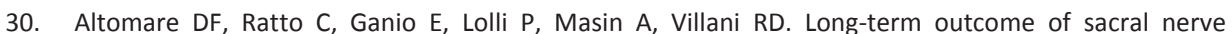

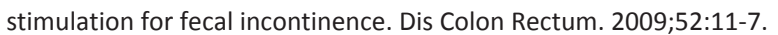

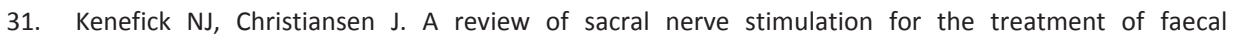

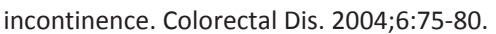

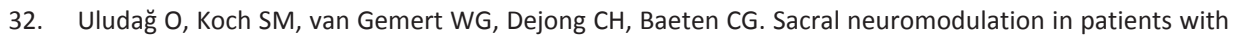

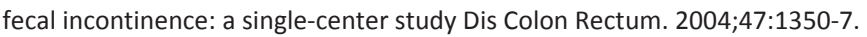

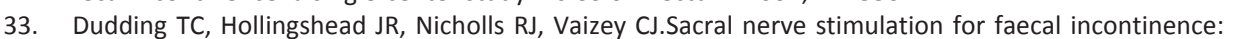

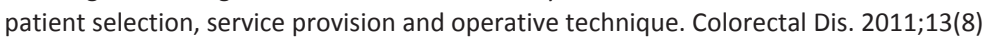

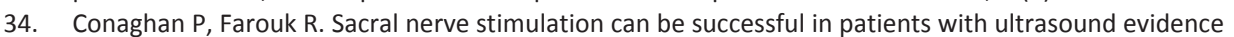

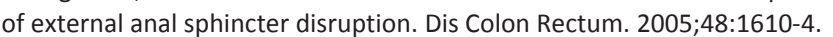

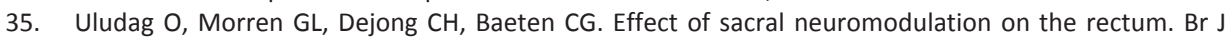

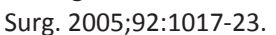

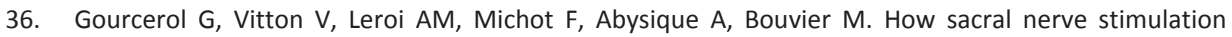

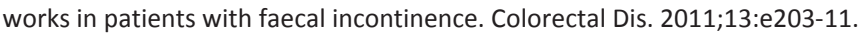

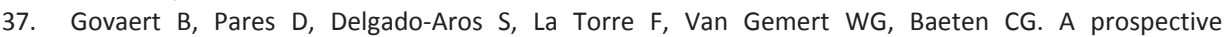

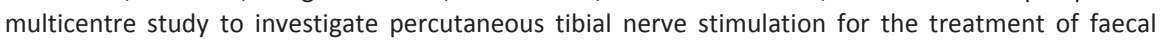

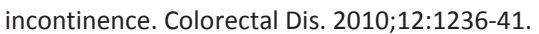

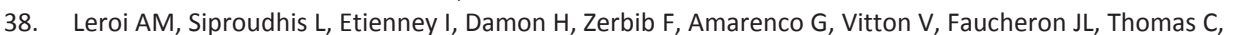

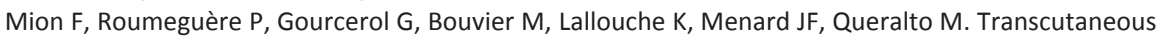

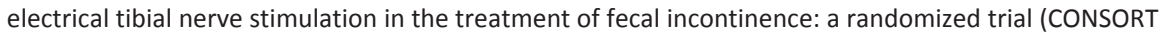

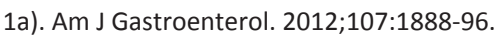

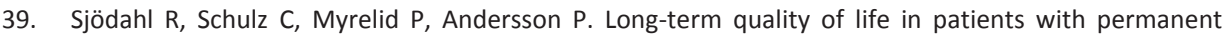

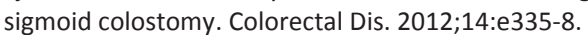

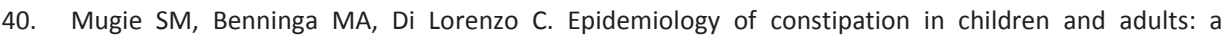

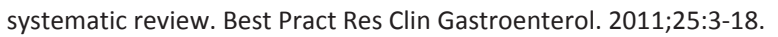

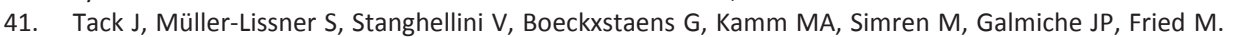

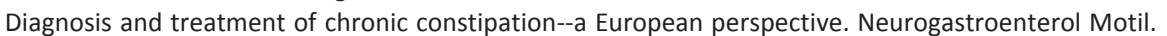

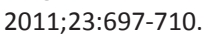

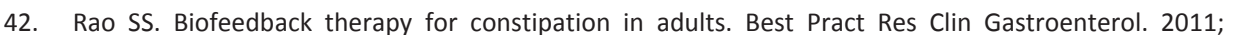

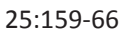




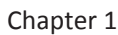

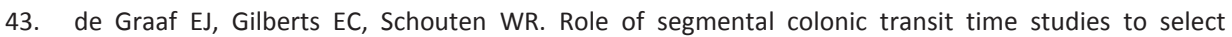

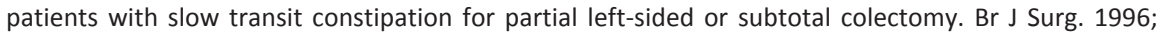

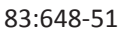

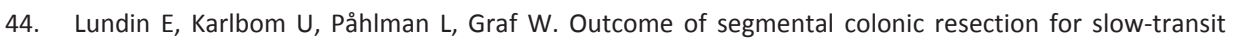

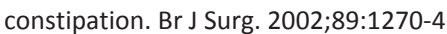

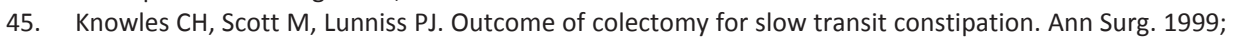

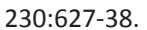

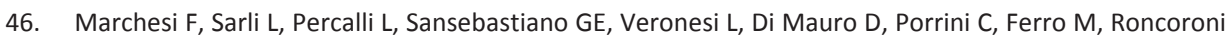

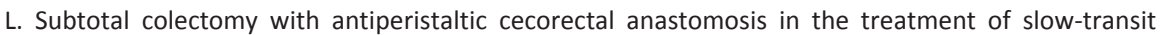

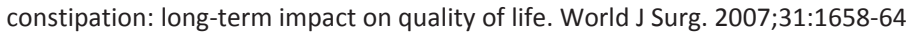

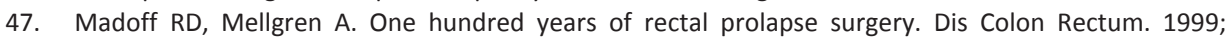

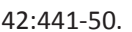

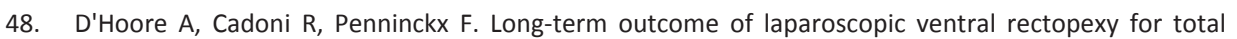

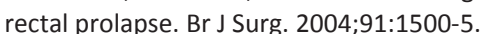

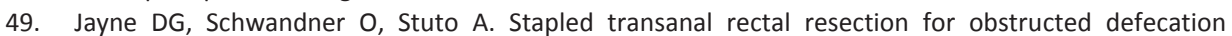

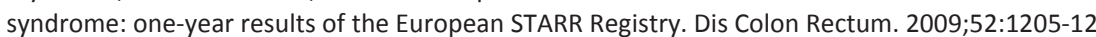




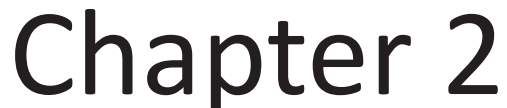

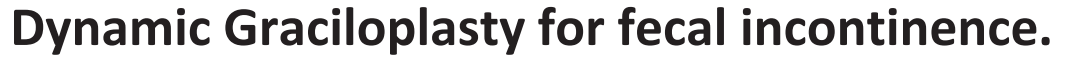

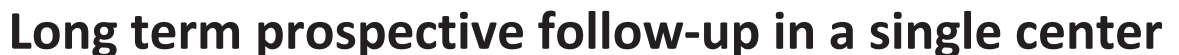

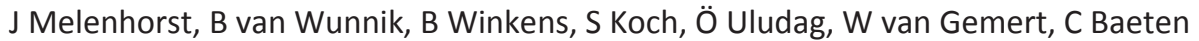

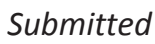




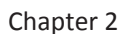

\section{?]?]?][|][?]?}

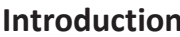

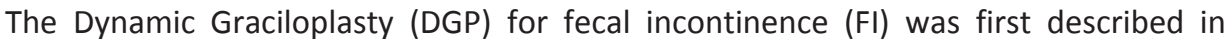

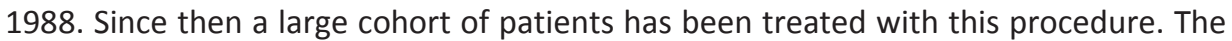

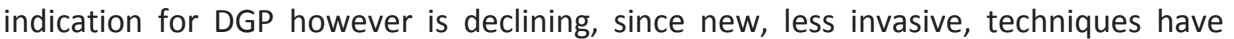

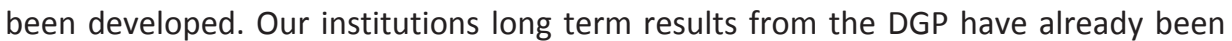

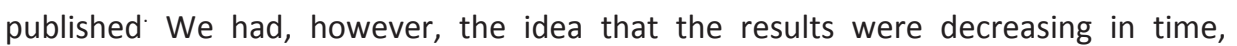

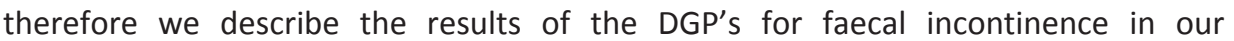

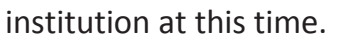

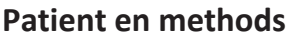

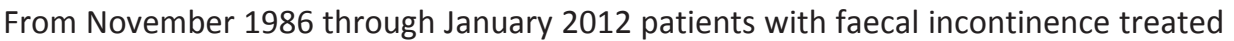

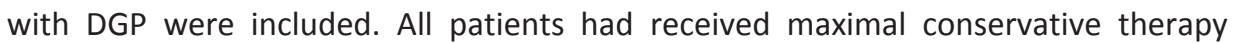

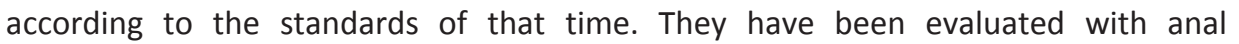

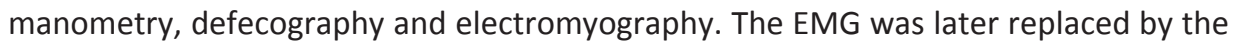

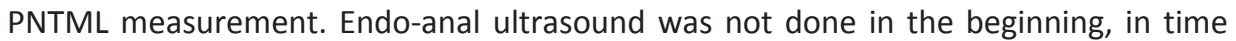

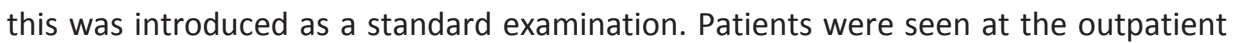

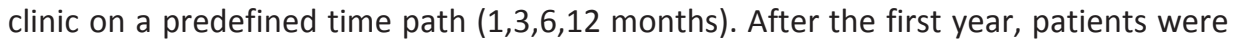

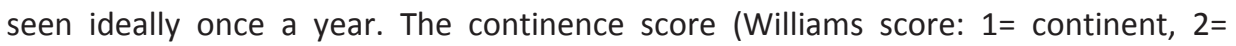

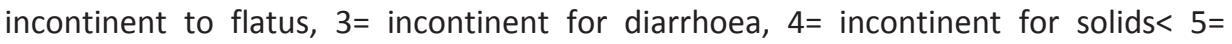
[5

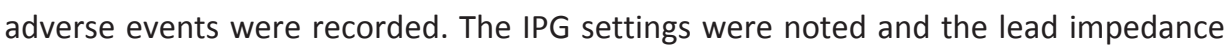

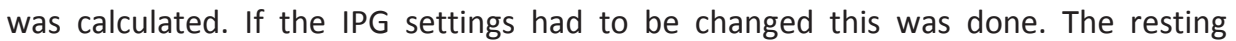

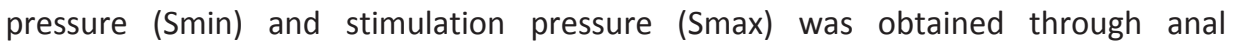

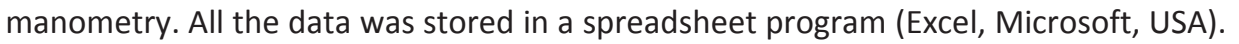

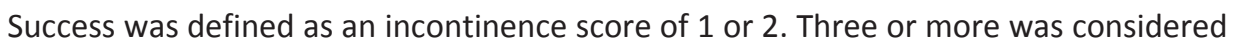

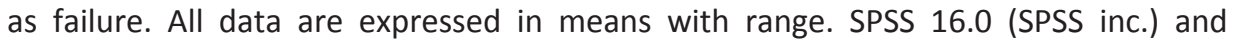

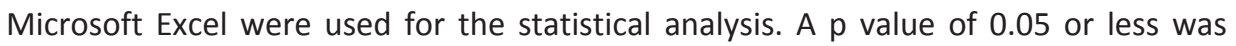

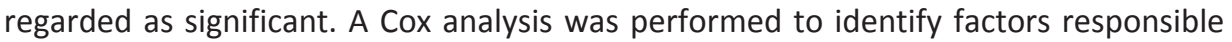

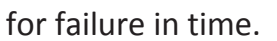

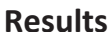

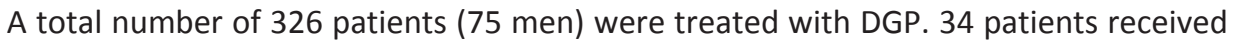

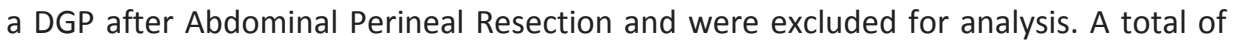

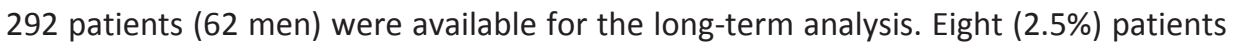

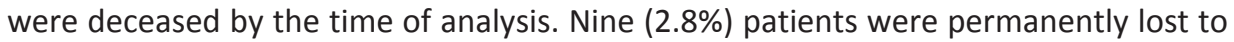

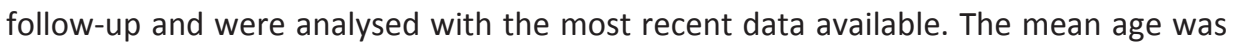

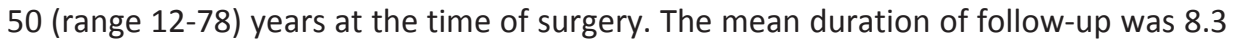

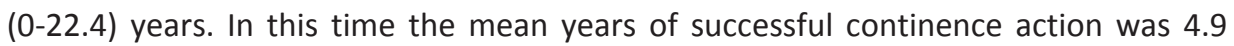

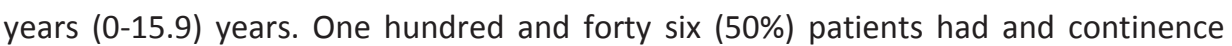

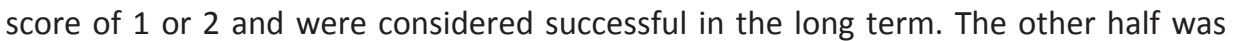




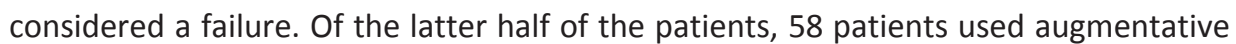

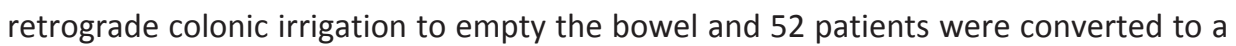

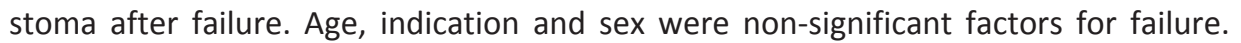

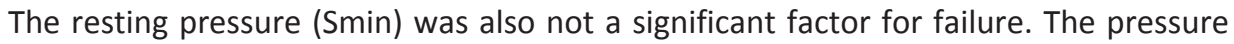

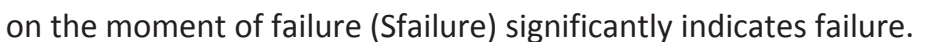

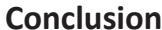

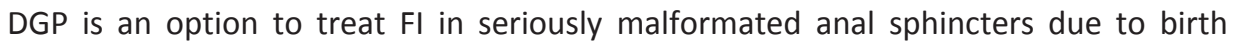

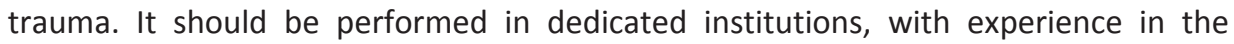

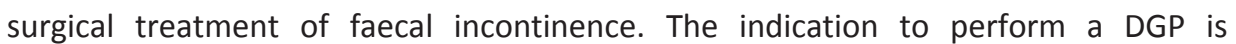

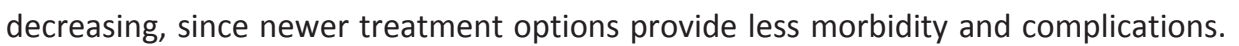

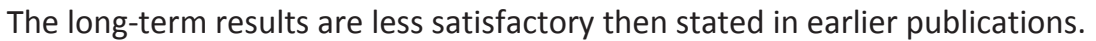




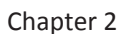

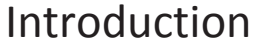

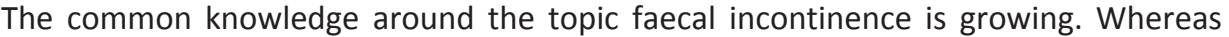

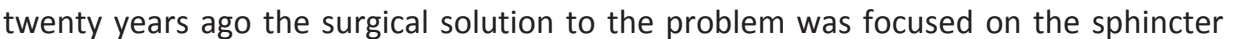

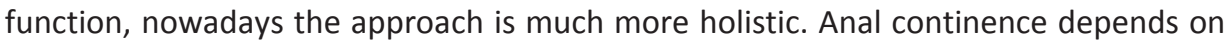

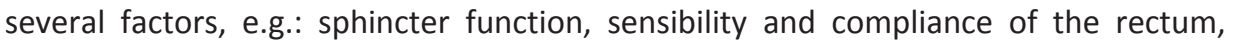

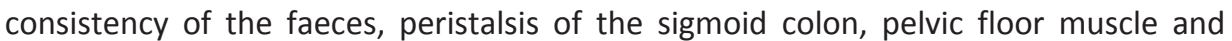

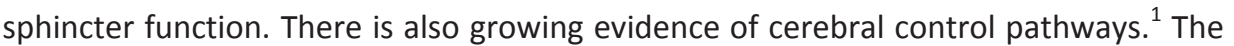

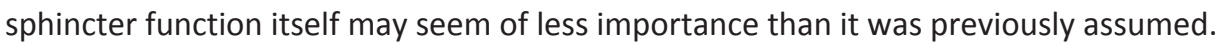

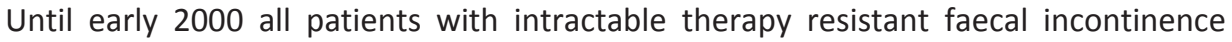

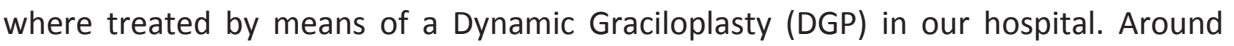

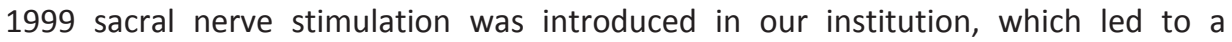

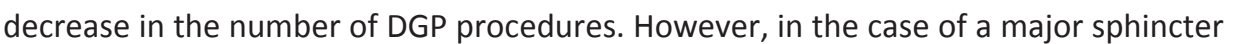

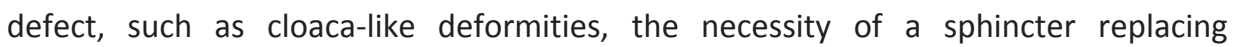

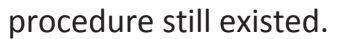

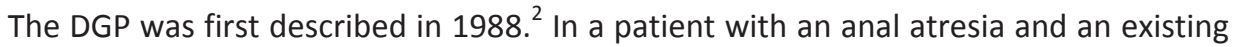

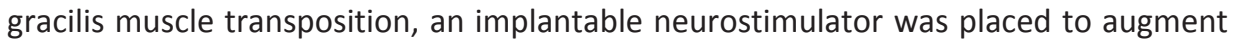

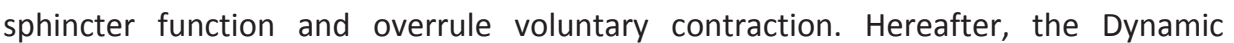

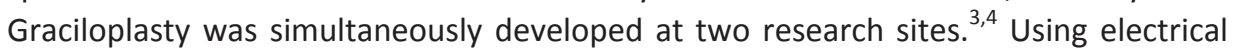

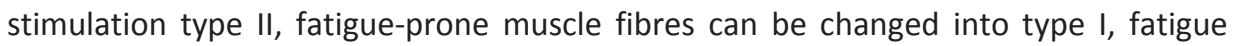

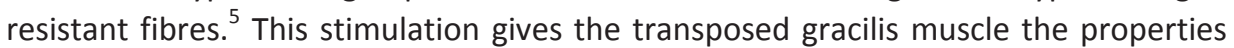

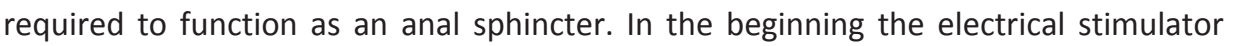

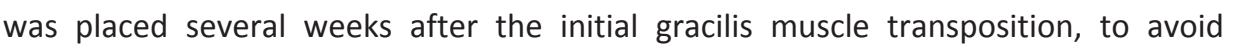

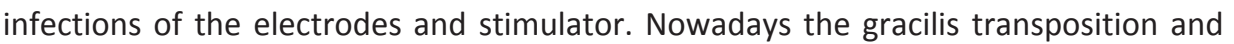

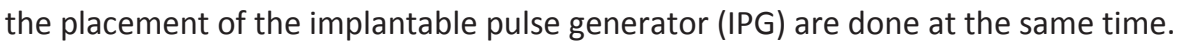

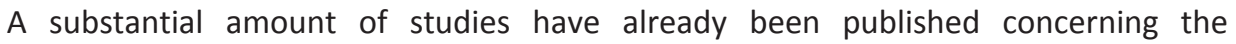

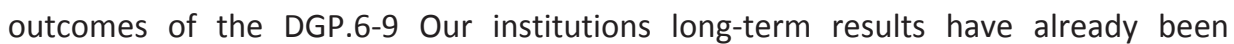

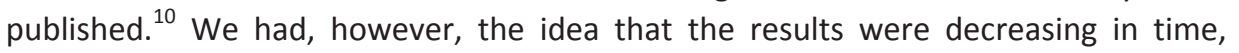

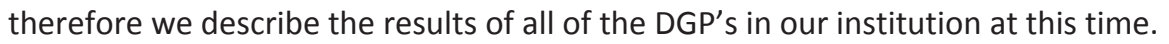

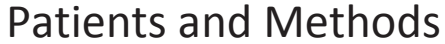

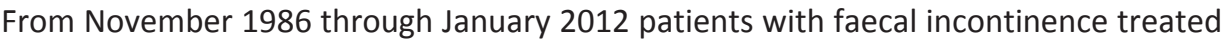

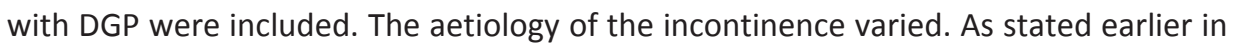

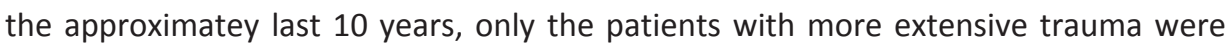

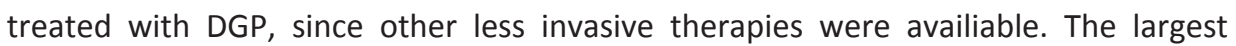

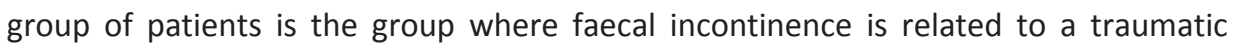

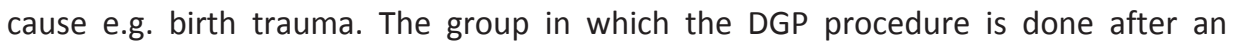

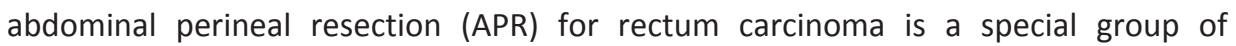

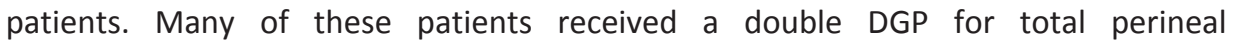

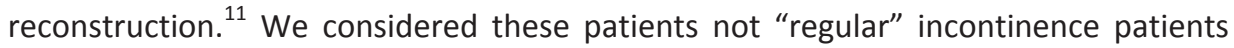




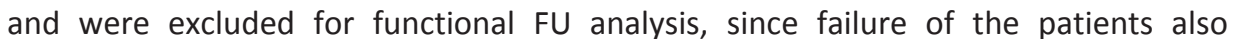

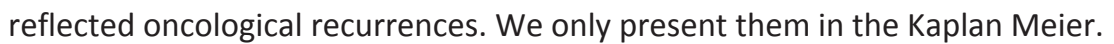

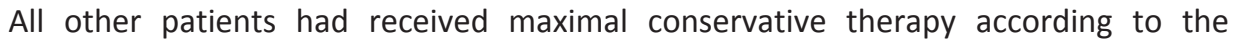

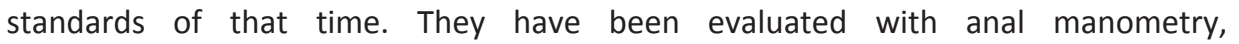

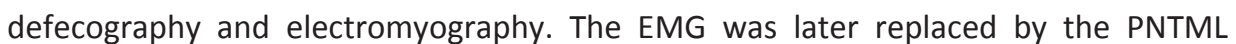

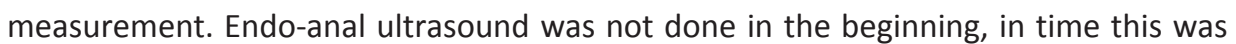

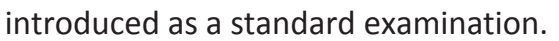

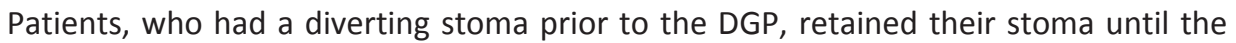

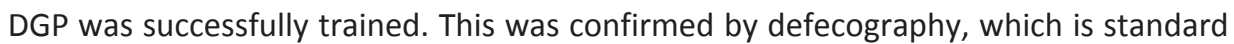

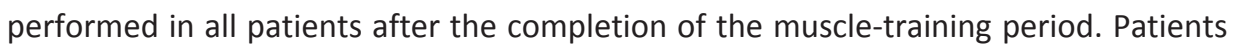

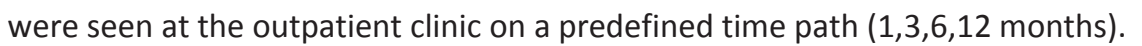

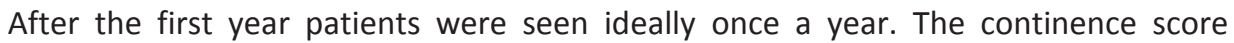

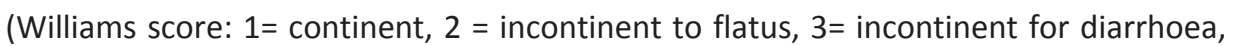

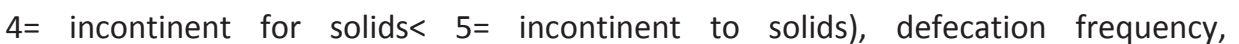

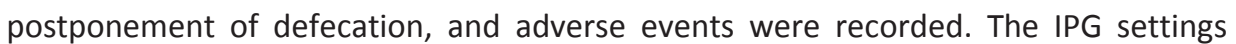

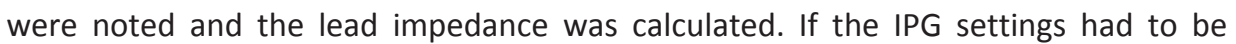

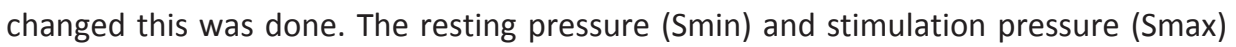

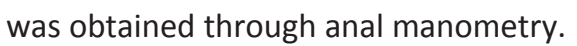

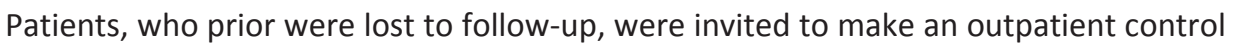

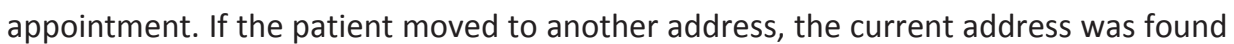

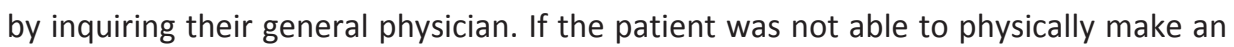

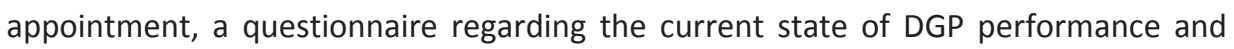

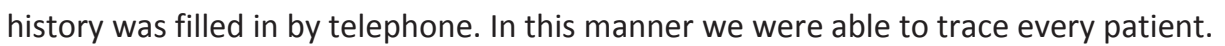

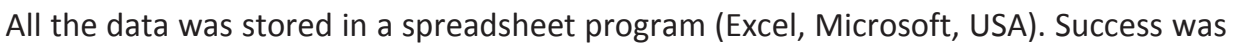

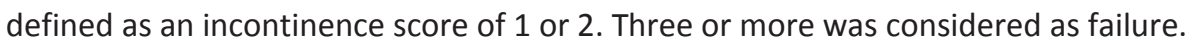

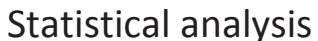

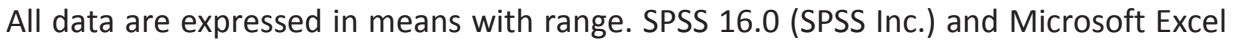

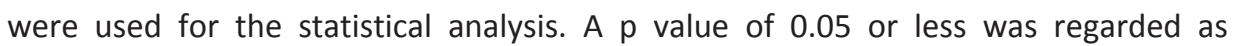

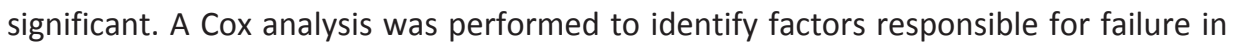

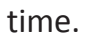

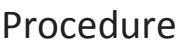

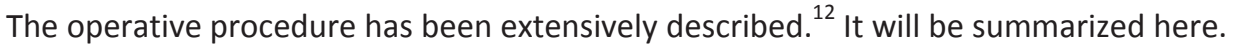

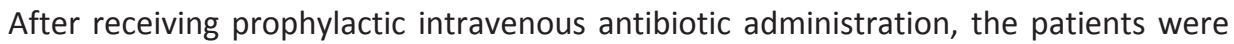

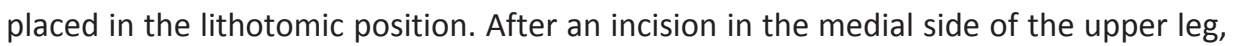

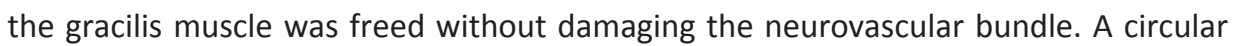

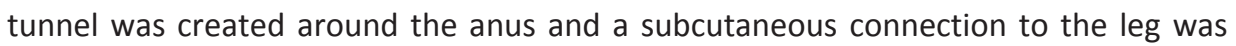

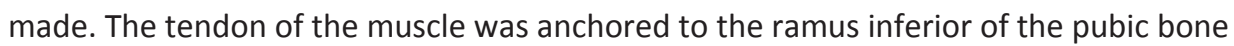

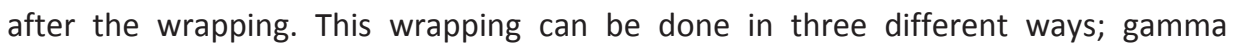




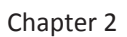

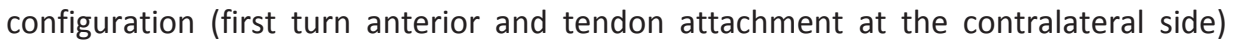

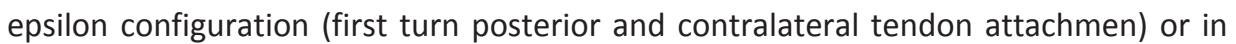

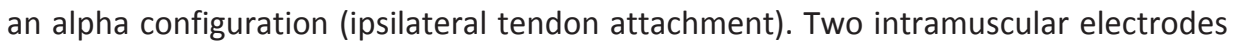

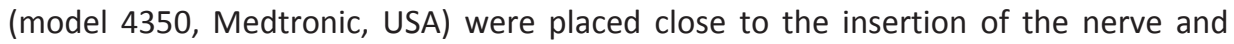

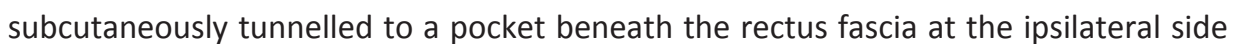

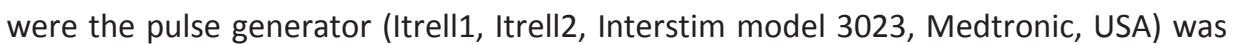

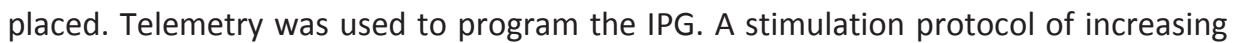

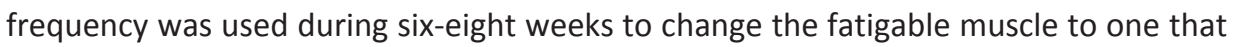

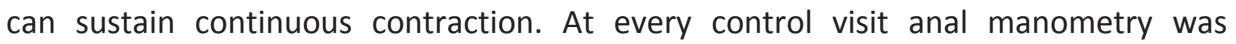

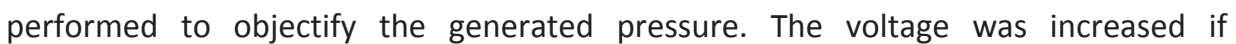

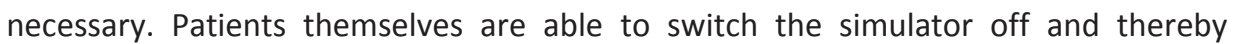

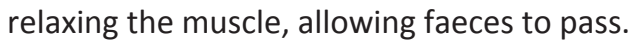

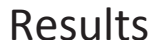

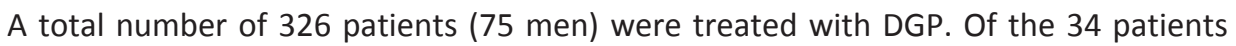

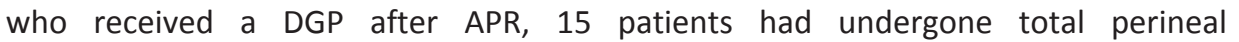

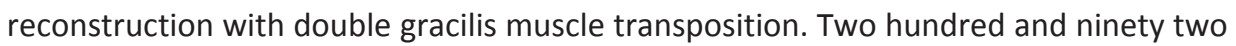

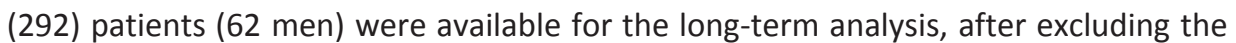

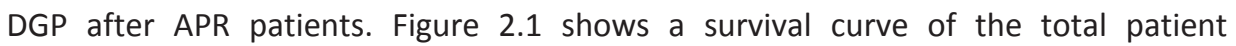

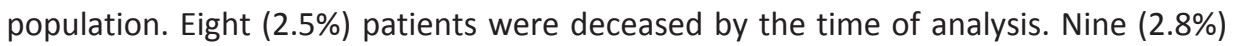

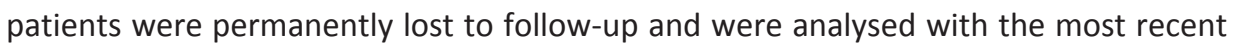

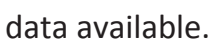

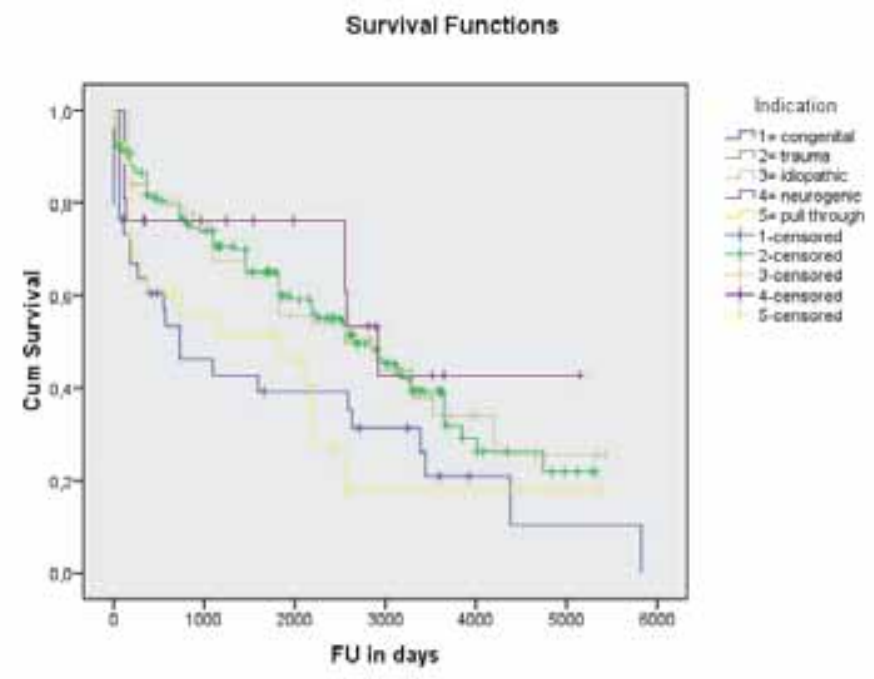

[?] 


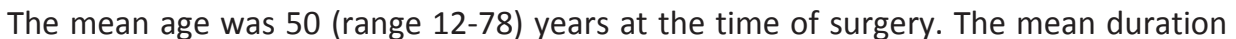

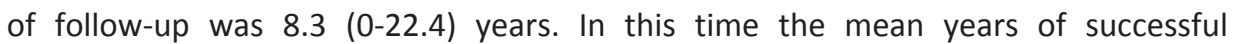

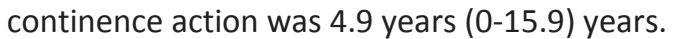

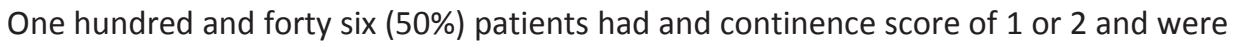

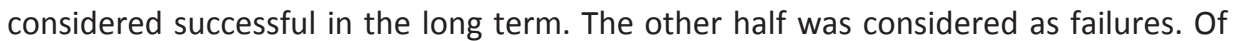

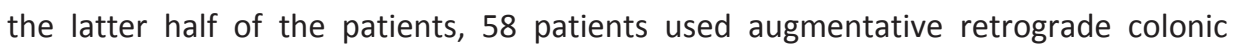
[5

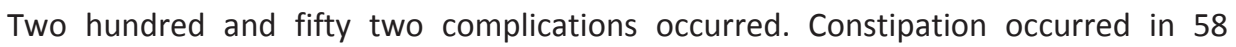

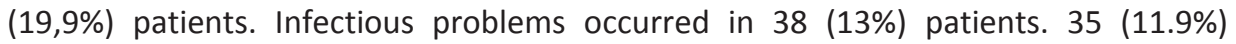

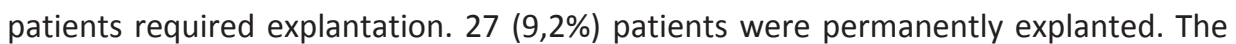

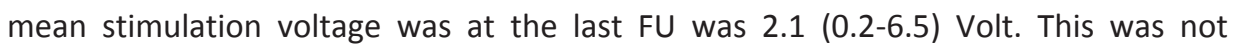

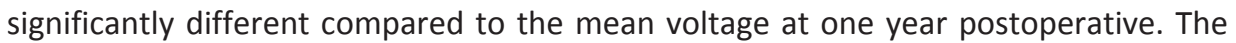

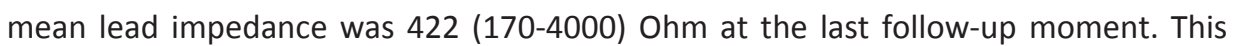

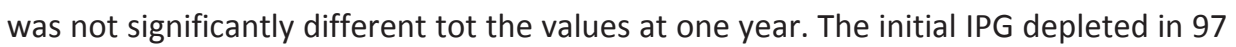

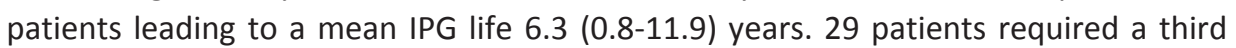

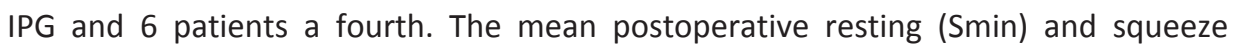

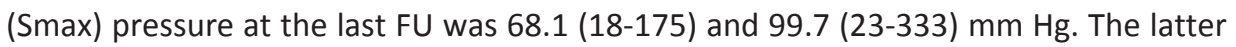

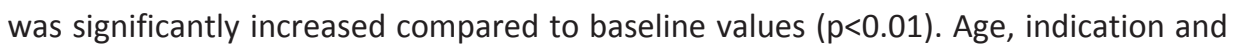

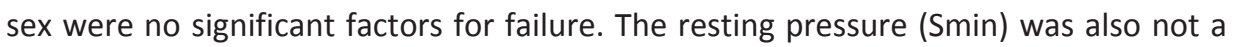

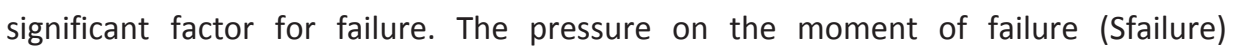

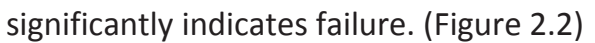

\section{Cox analysis}

\begin{tabular}{|c|c|c|c|c|c|c|c|c|}
\hline \multirow[b]{3}{*}{ Age } & \multirow[b]{2}{*}{ B } & \multirow[b]{2}{*}{ SE } & \multirow[b]{2}{*}{ Wald } & \multirow[b]{2}{*}{ df } & \multirow[b]{2}{*}{ Sig. } & \multirow[b]{2}{*}{$\operatorname{Exp}(B)$} & \multicolumn{2}{|c|}{$95,0 \%$ Cl for $\operatorname{Exp}(B)$} \\
\hline & & & & & & & Lower & Upper \\
\hline & 0,001 & 0,006 & 0,021 & & 0,884 & 1,001 & 0,989 & 1,013 \\
\hline Indication & $-0,221$ & 0,131 & 2,858 & & 0,091 & 0,802 & 0,621 & 1,036 \\
\hline M/V & 0,018 & 0,205 & 0,008 & & 0,929 & 1,018 & 0,682 & 1,521 \\
\hline Sfailure & $-0,022$ & 0,007 & 11,469 & & 0,001 & 0,978 & 0,966 & 0,991 \\
\hline Smin & 0,009 & 0,005 & 3,063 & & 0,08 & 1,009 & 0,999 & 1,019 \\
\hline Smax & $-0,022$ & 0,004 & 37,175 & & 0 & 0,98 & 0,972 & 0,986 \\
\hline
\end{tabular}

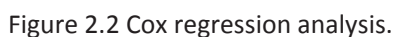

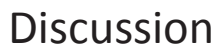

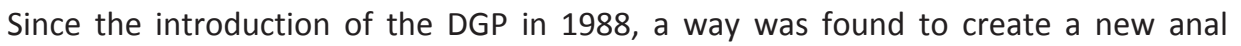

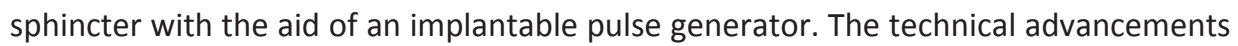

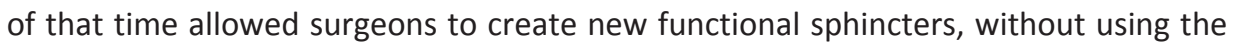

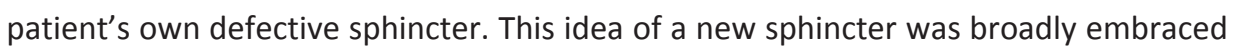




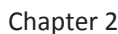

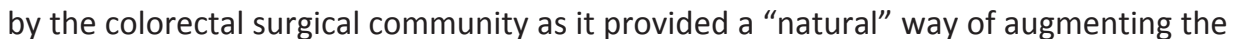

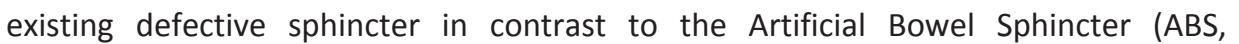

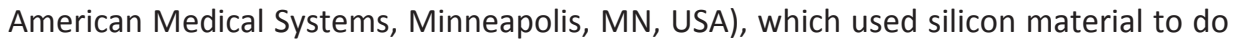

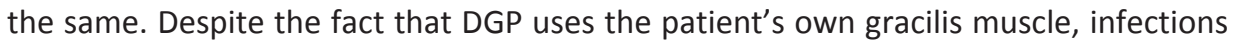

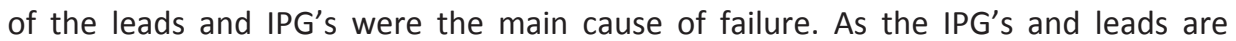

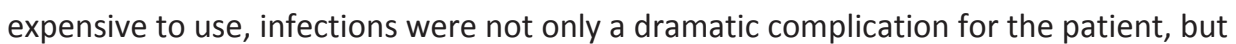

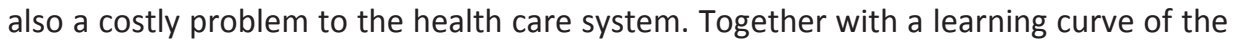

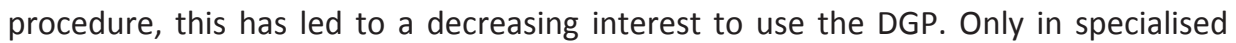

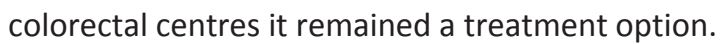

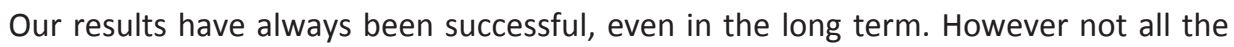

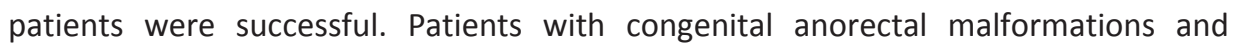

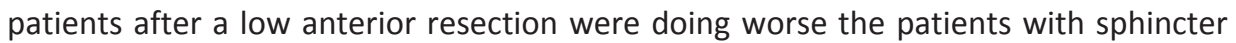

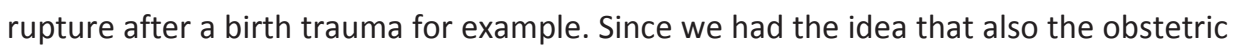

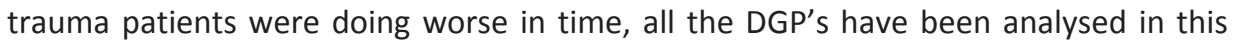

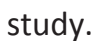

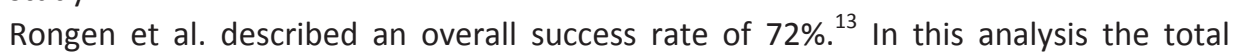

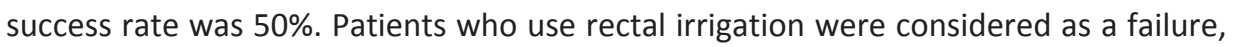

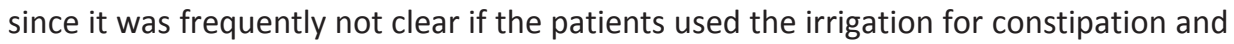

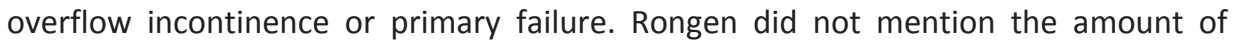

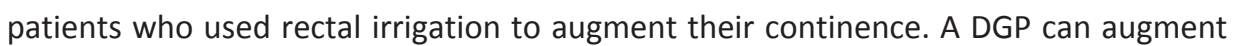

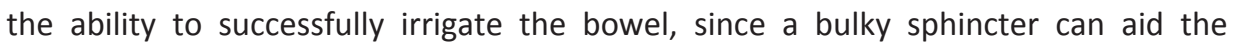

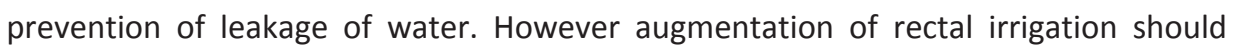

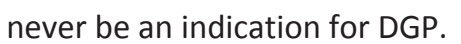

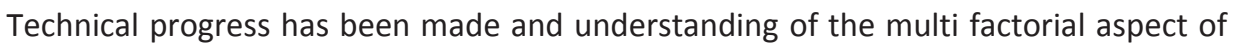

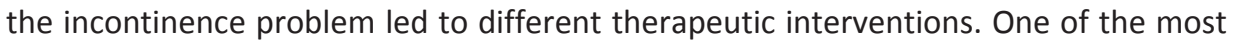

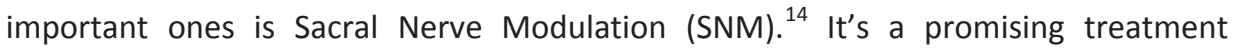

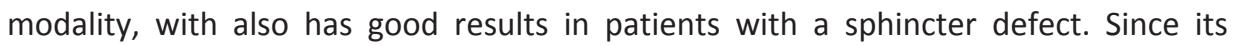

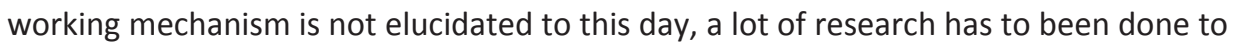

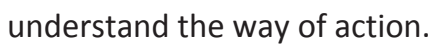

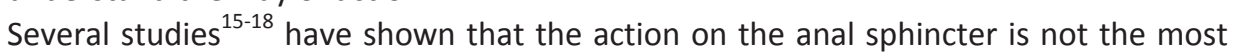

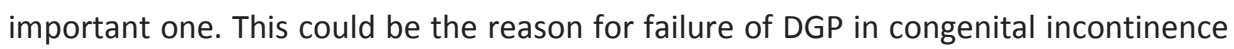

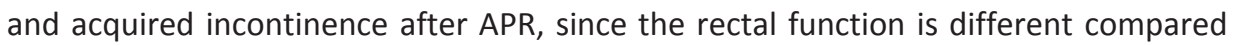

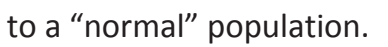

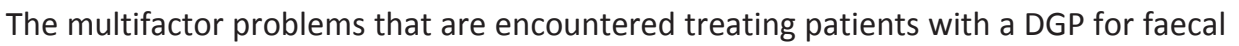

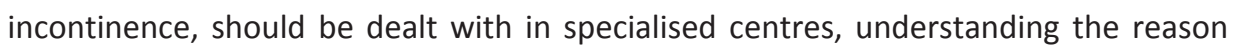

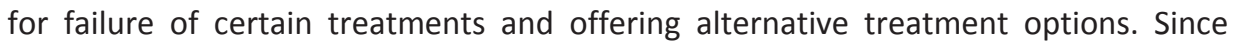

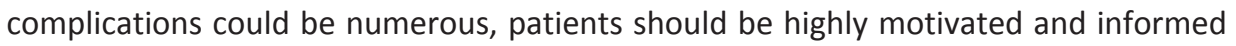

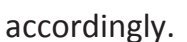

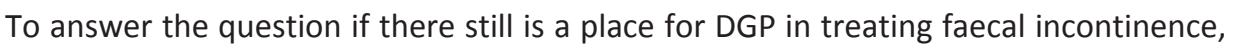

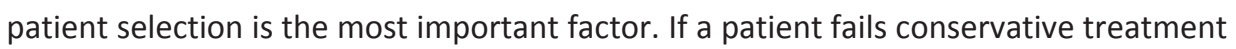

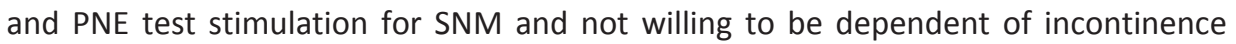




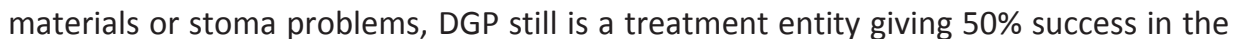

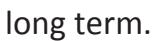

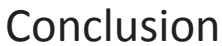

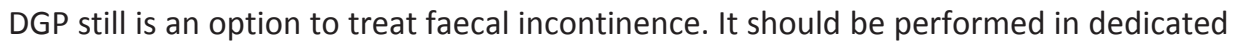

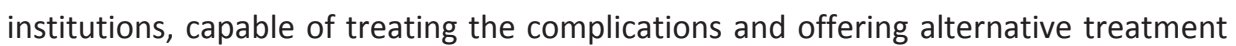

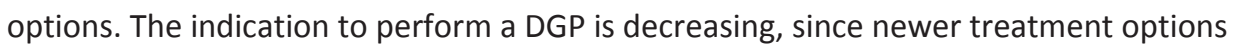

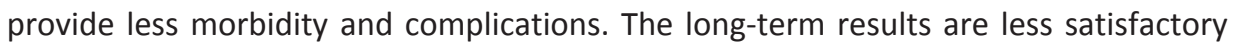

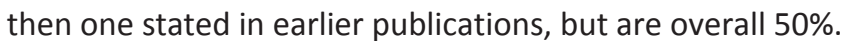




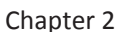

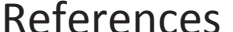

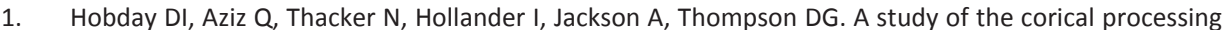

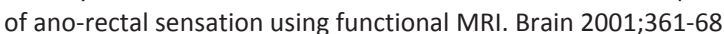

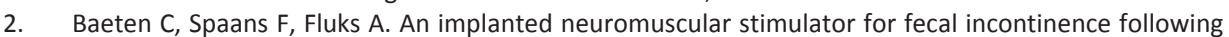

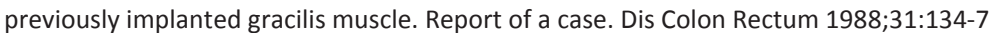

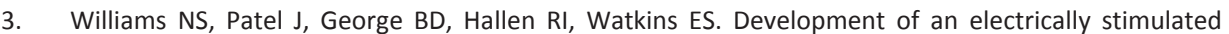

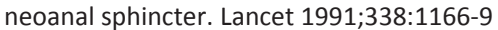

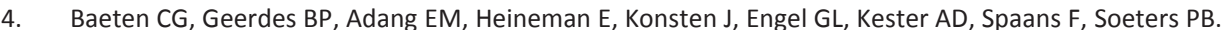

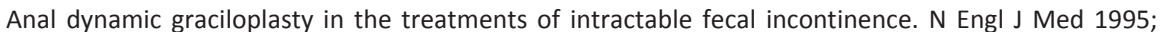

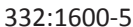

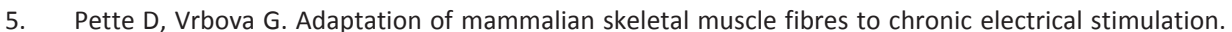

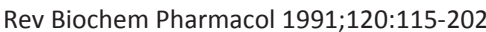

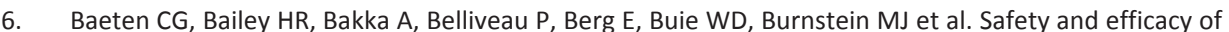

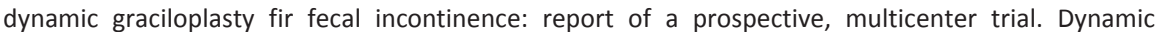

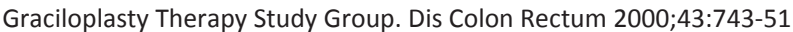

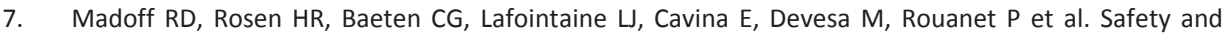

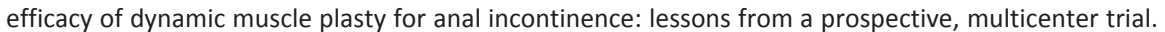

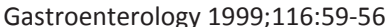

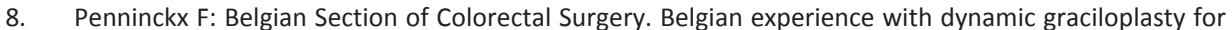

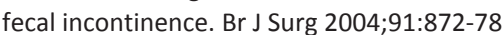

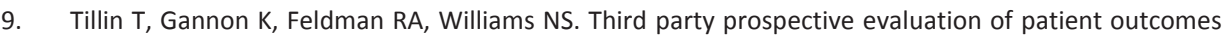

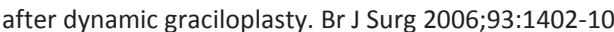

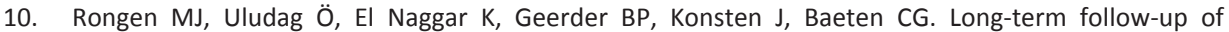

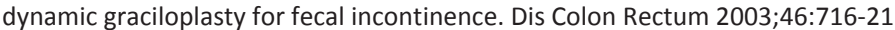

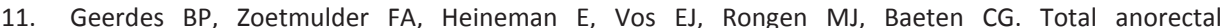

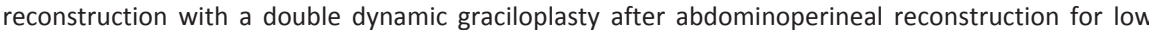

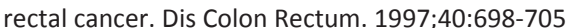

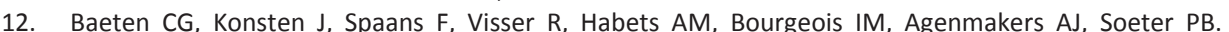

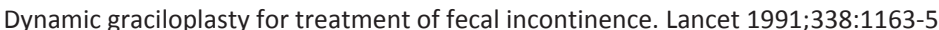

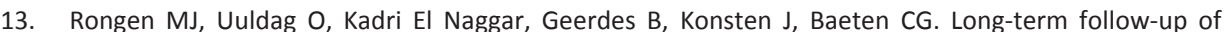

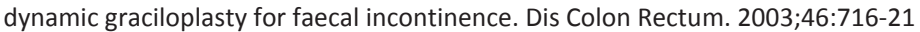

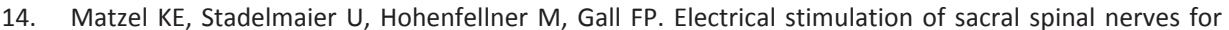

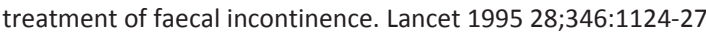

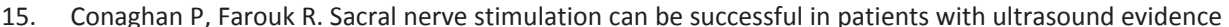

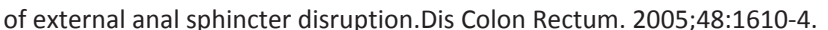

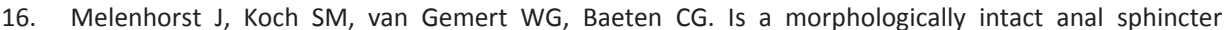

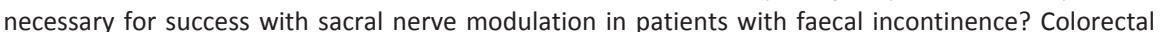

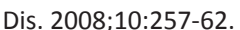

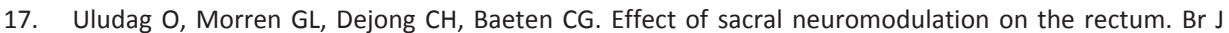

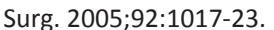

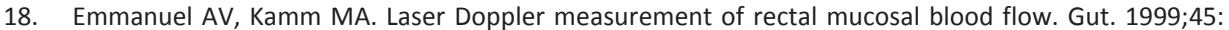
???? 


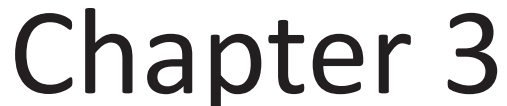

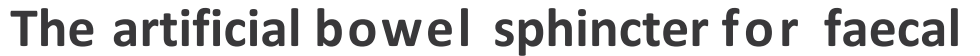

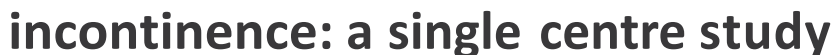

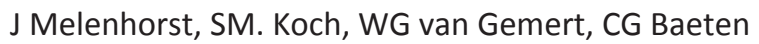

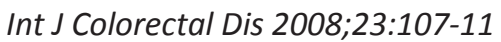




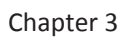

\section{?]?]?]?][?]?]}

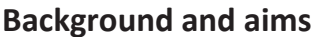

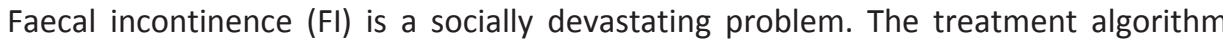

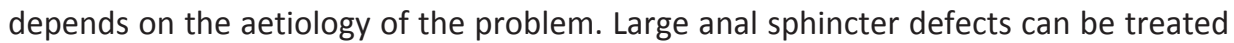

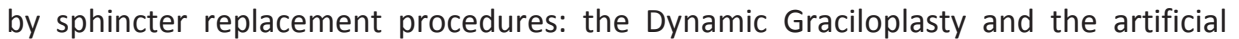

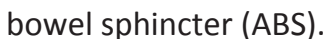

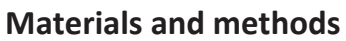

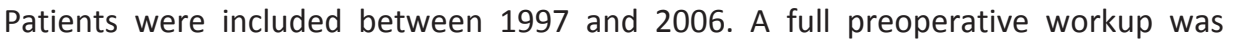

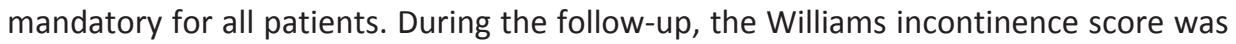

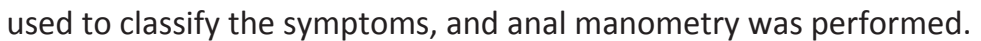

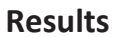

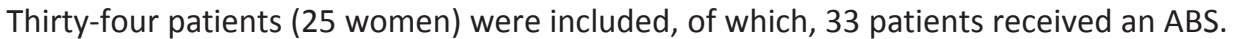

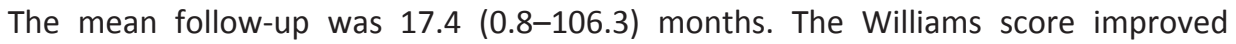

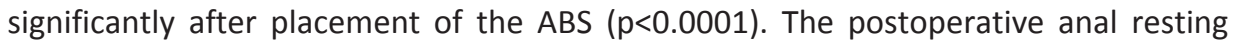

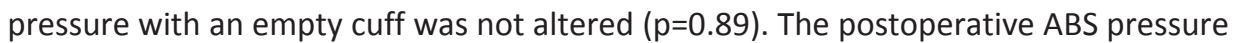

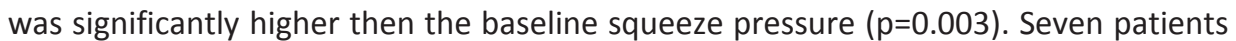

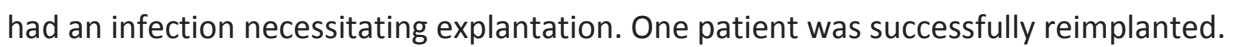

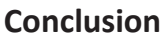

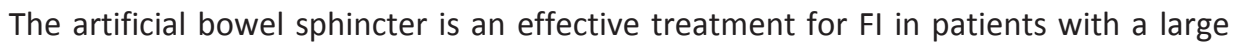

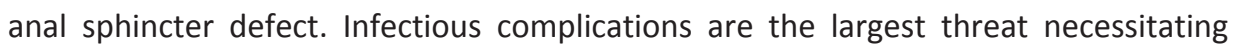

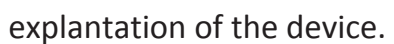




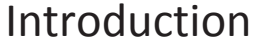

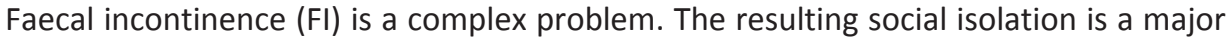

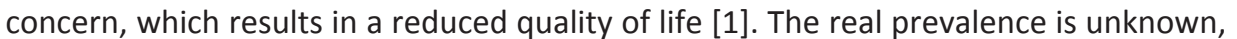

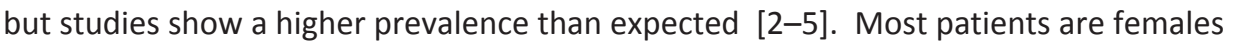

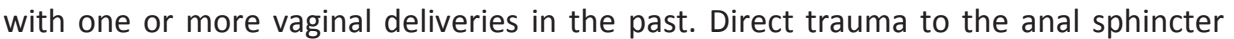

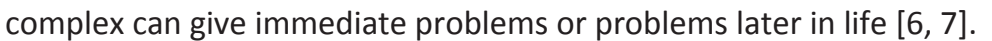

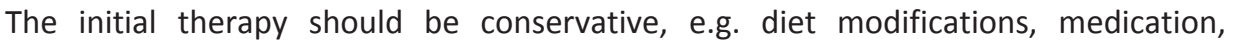

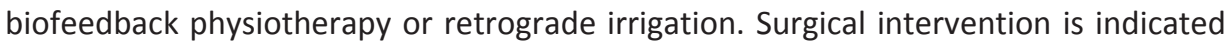

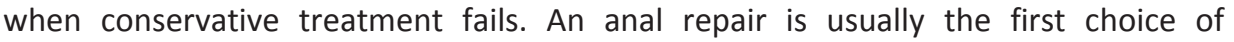

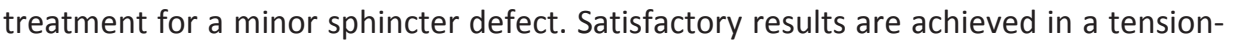

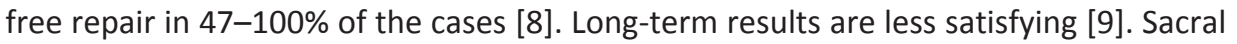

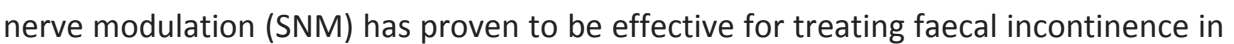

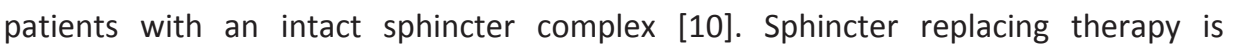

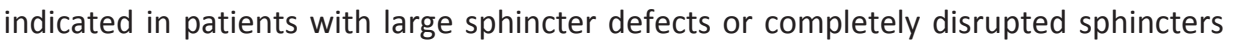

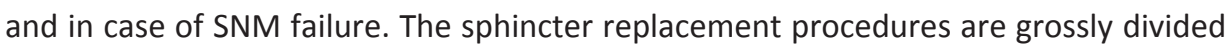

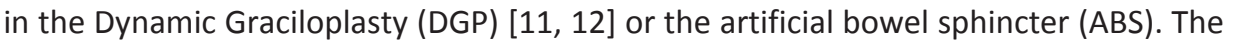

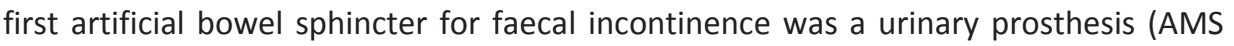

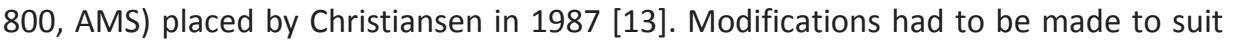

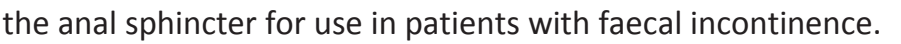

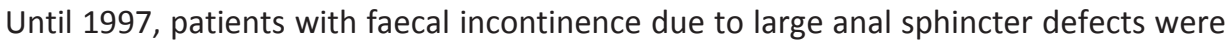

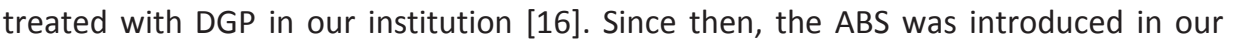

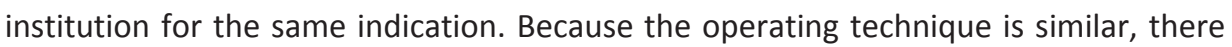

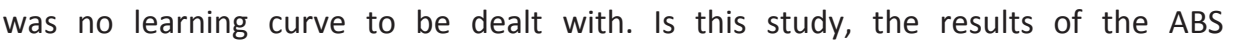

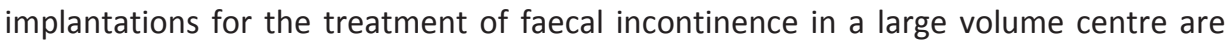

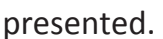

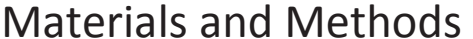

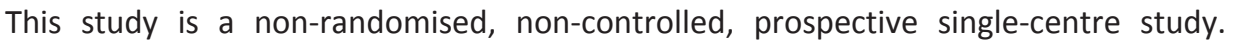

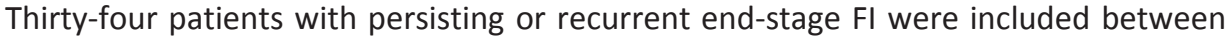

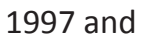

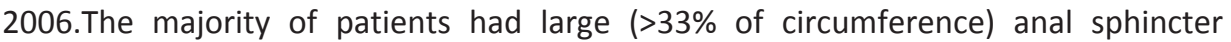

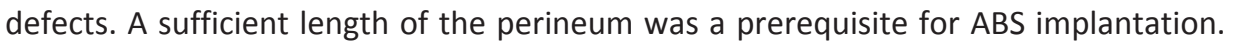

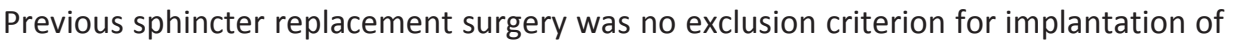

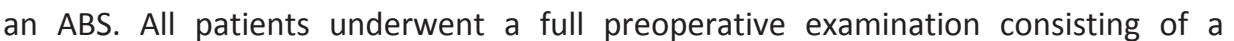

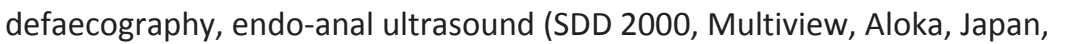

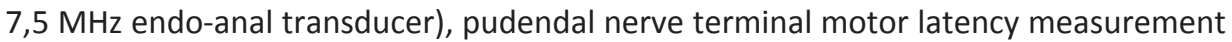

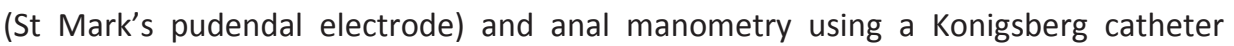

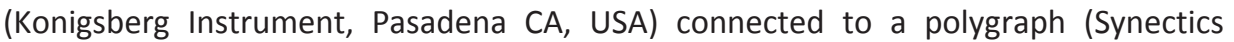

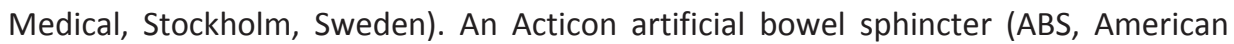




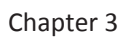

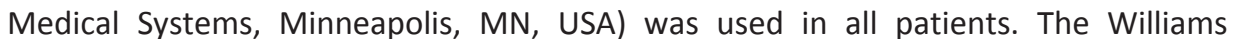

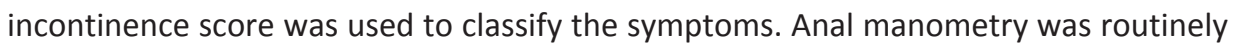

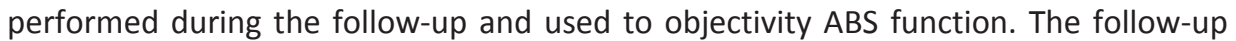

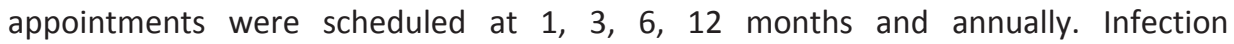

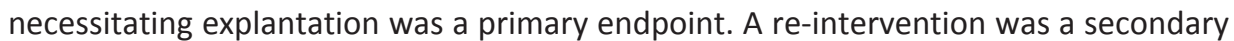

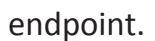

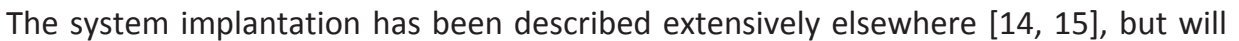

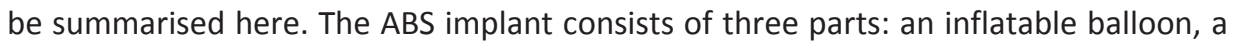

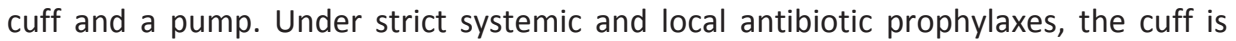

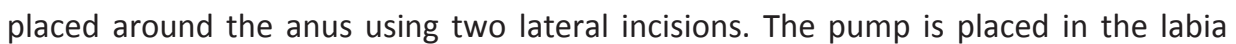

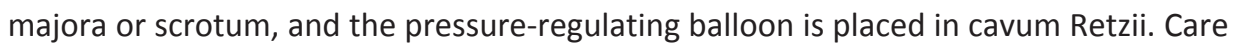

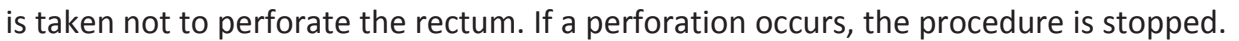

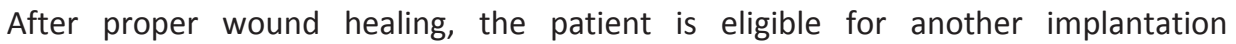

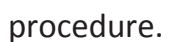

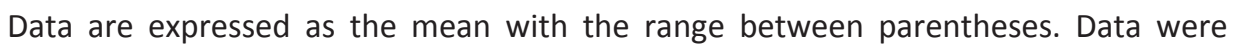

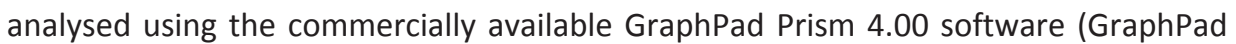

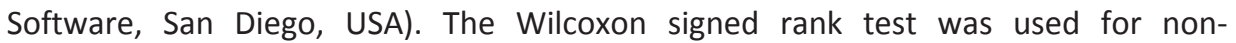

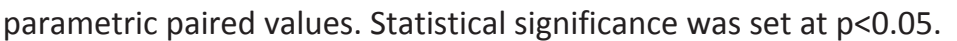

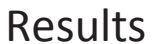

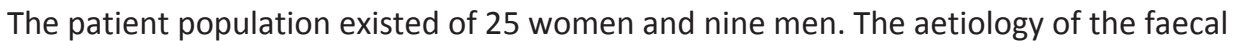

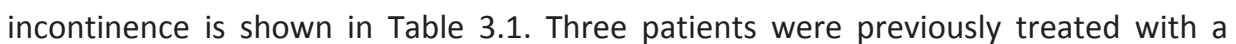

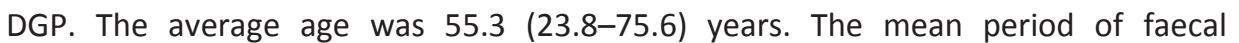

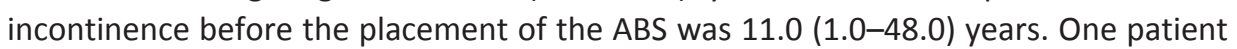

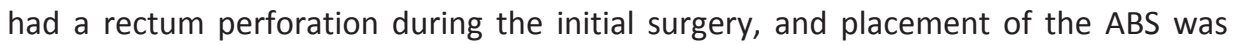

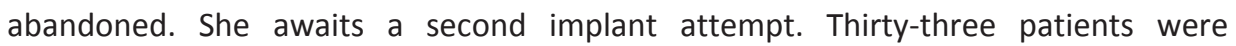

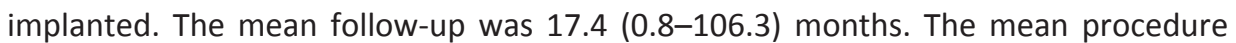

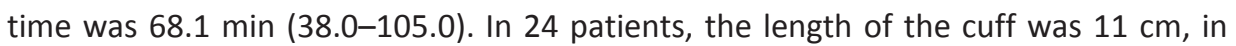

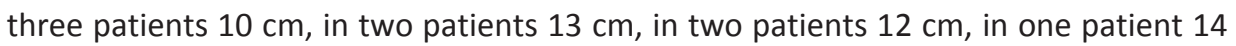

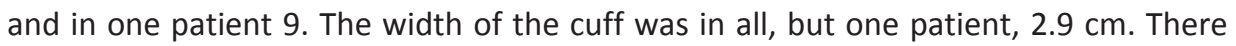

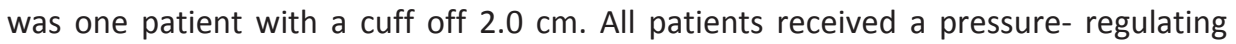

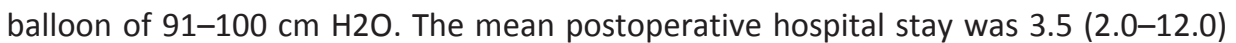

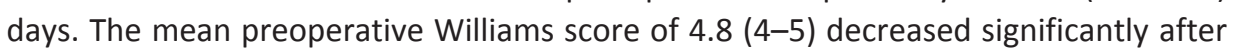

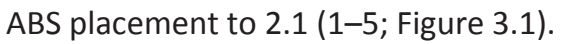




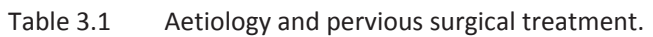

\begin{tabular}{|c|c|c|c|}
\hline 回回? 回回? & ?]??]? & 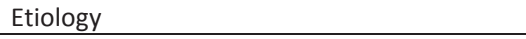 & 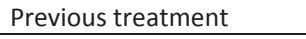 \\
\hline ? & ? & 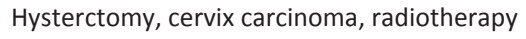 & \\
\hline 圆 & ? & 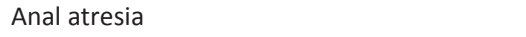 & 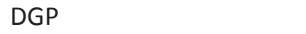 \\
\hline 圆 & ? & 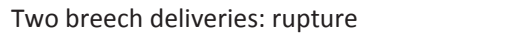 & 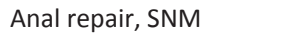 \\
\hline 回 & ? & 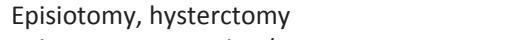 & 에의 의 \\
\hline 目 & ? & 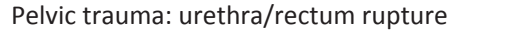 & 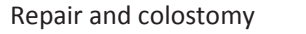 \\
\hline ? & ? & 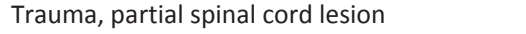 & ?ㅇ?의 \\
\hline ? & ? & 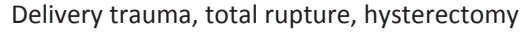 & 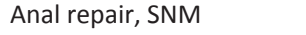 \\
\hline 回 & ? & 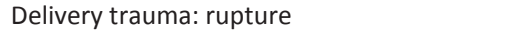 & \\
\hline ? & ? & 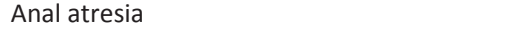 & \\
\hline ?]? & ? & 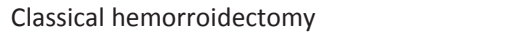 & \\
\hline ?]? & ? & 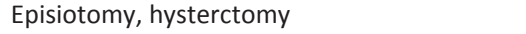 & 의?의 \\
\hline ?]? & ? & 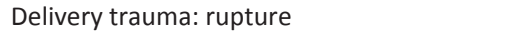 & 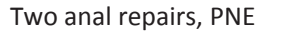 \\
\hline ?]? & ? & 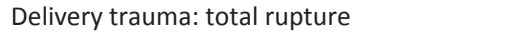 & 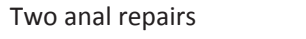 \\
\hline [?]? & ? & 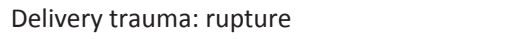 & 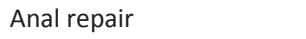 \\
\hline ?]? & ? & 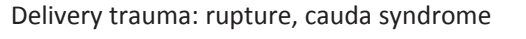 & 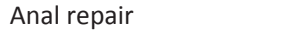 \\
\hline ?]? & ? & 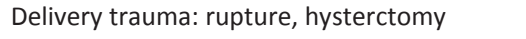 & 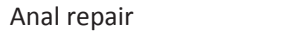 \\
\hline [?]? & ? & 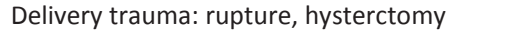 & 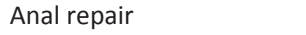 \\
\hline ?]? & ? & 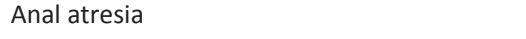 & ㅇ?의 \\
\hline ?]? & ? & 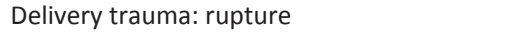 & 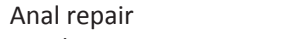 \\
\hline ?]? & ? & 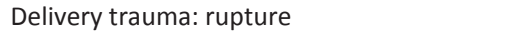 & 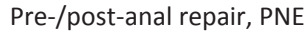 \\
\hline ?]? & ? & 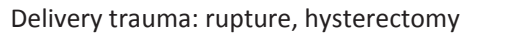 & 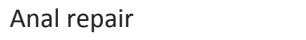 \\
\hline ?]? & ? ? & 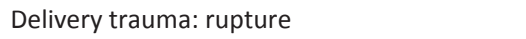 & 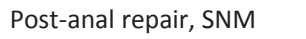 \\
\hline ?]? & ? & 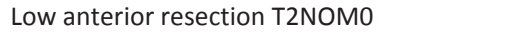 & \\
\hline ?]? & ? & 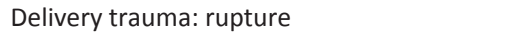 & \\
\hline ?]? & ? & 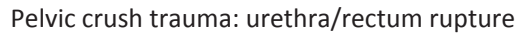 & 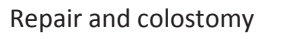 \\
\hline ?]? & ? & 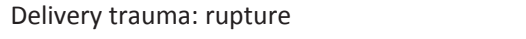 & \\
\hline ?]? & ? & 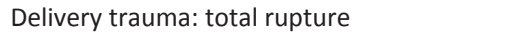 & 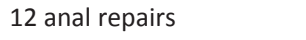 \\
\hline ?]? & ? & 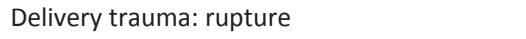 & 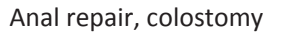 \\
\hline ?]? & ?] & 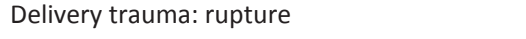 & 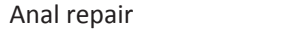 \\
\hline ?]? & ? & 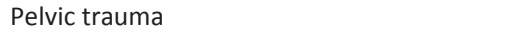 & \\
\hline ?]? & ? & 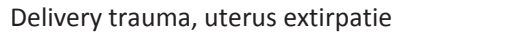 & ?의? \\
\hline ?]? & ? & 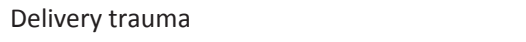 & 의?으 \\
\hline ?]? & ?] & 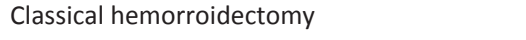 & 제?]?]? \\
\hline ?]? & ? & 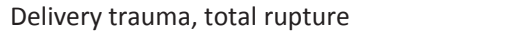 & 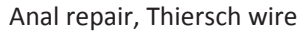 \\
\hline ?]? & ? & 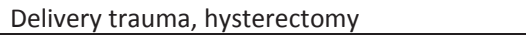 & ㅇ?무요 \\
\hline
\end{tabular}

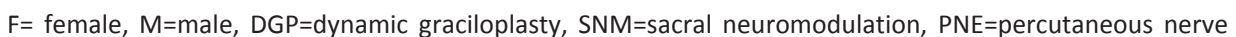

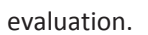

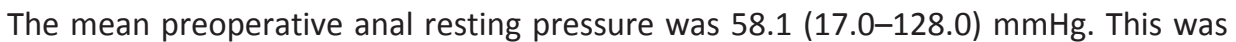

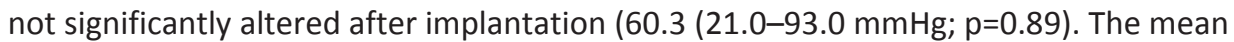

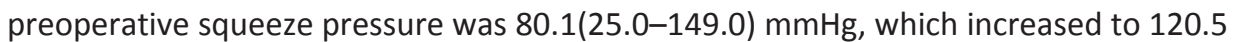

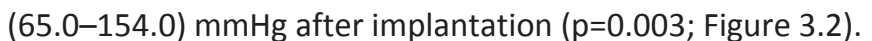




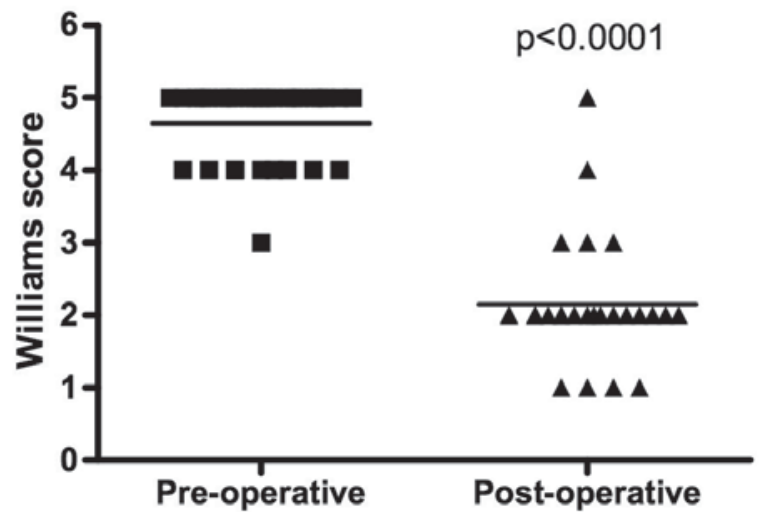

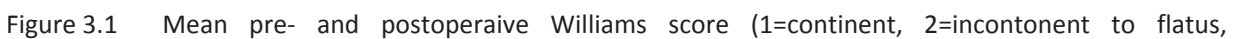

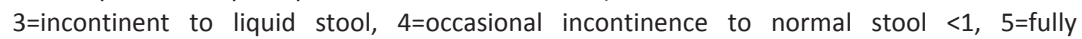

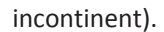

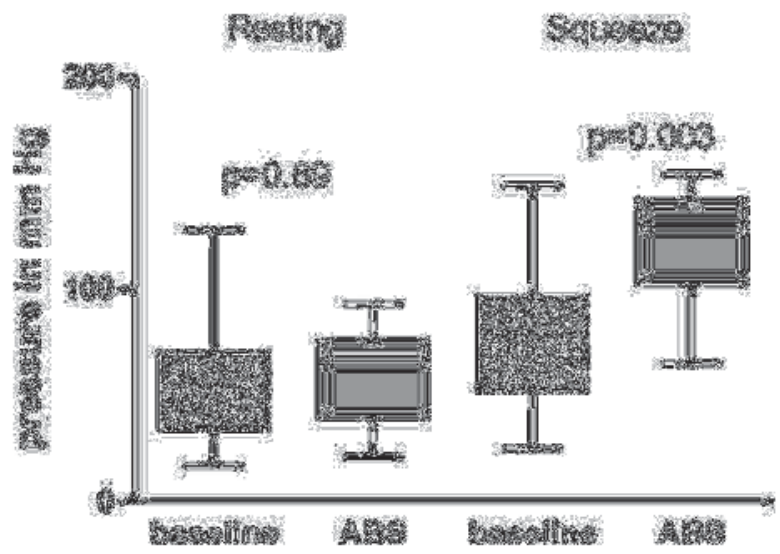

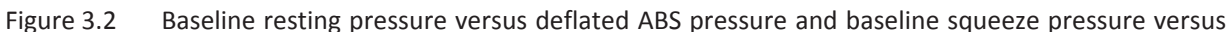

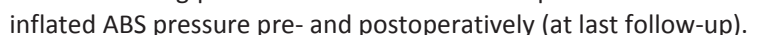

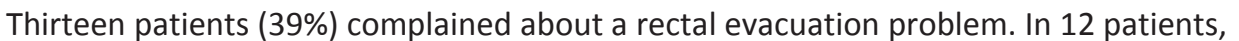

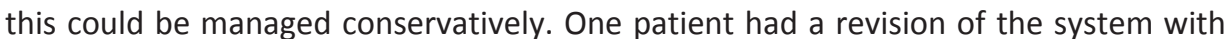

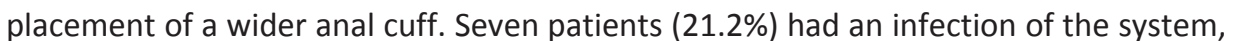

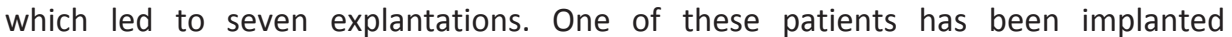

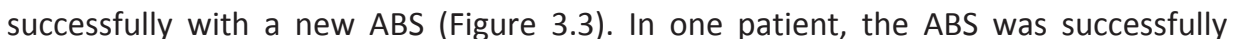

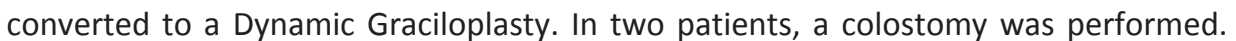

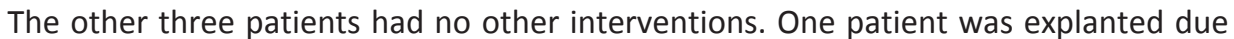




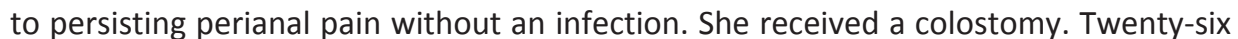

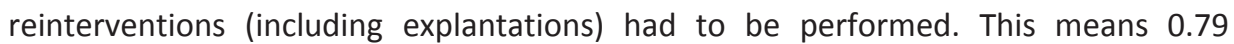

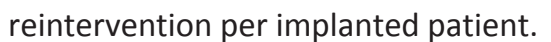

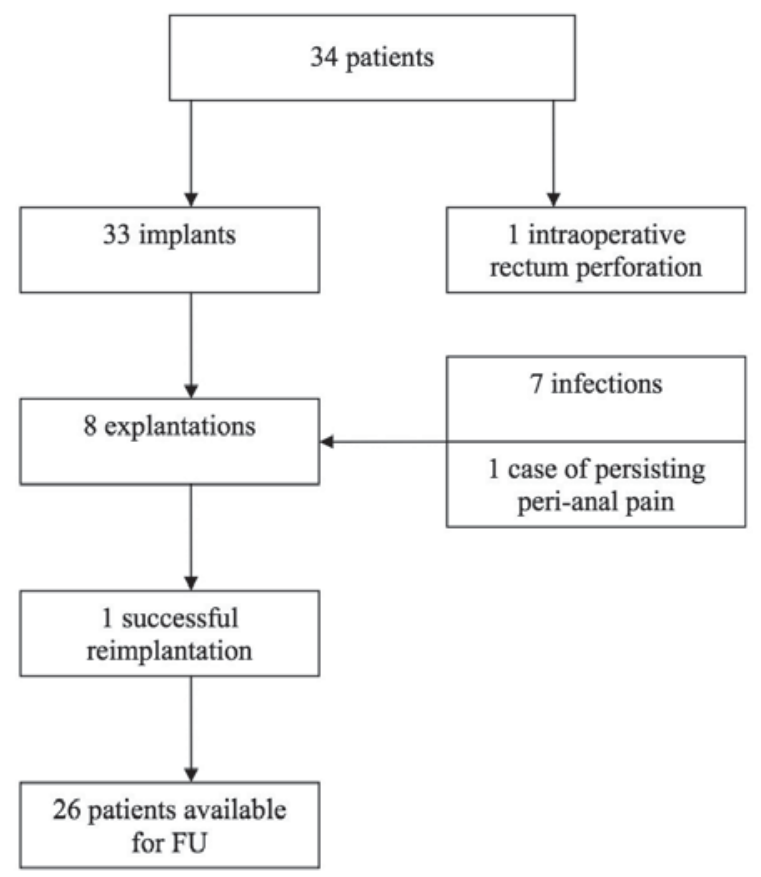

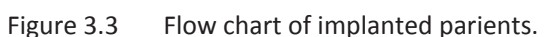

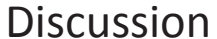

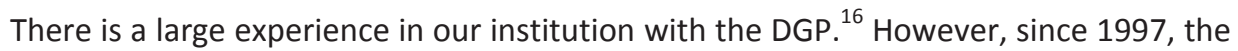

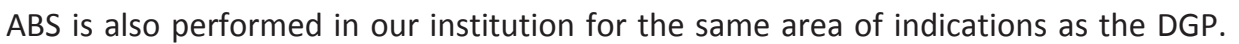

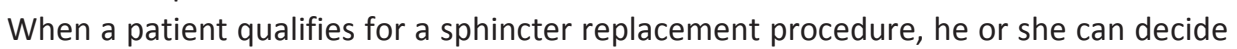

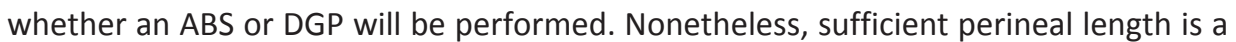

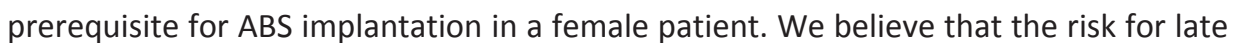

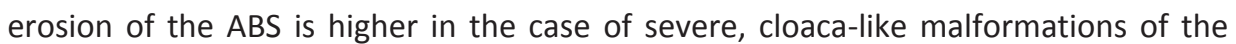

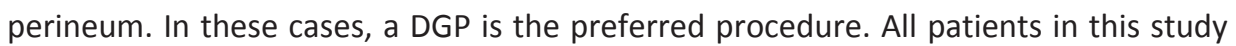

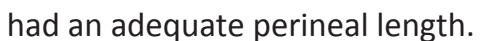

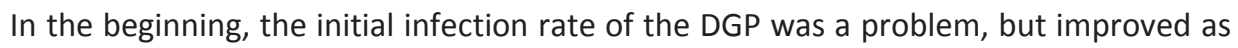

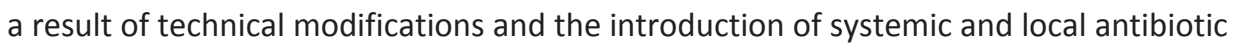

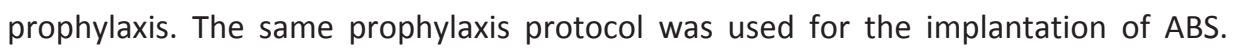

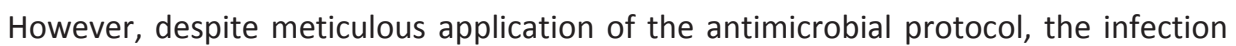




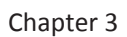

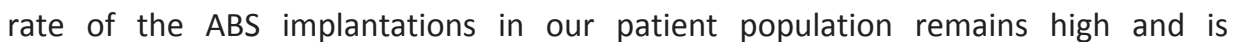

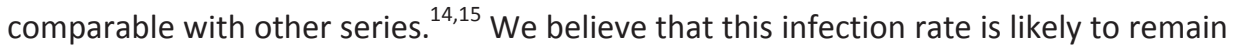

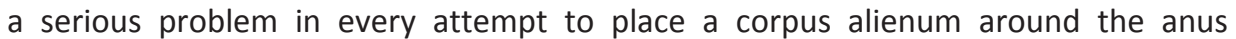

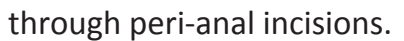

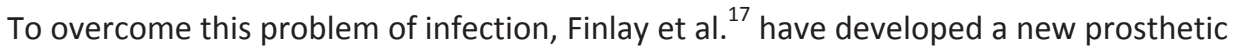

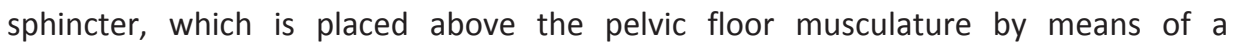

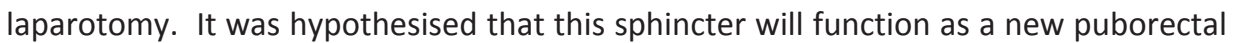

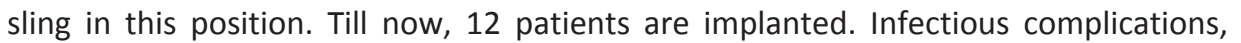

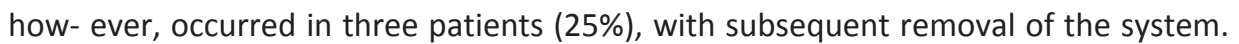

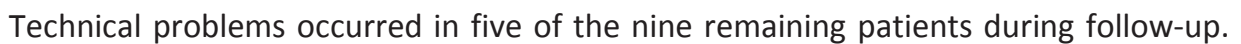

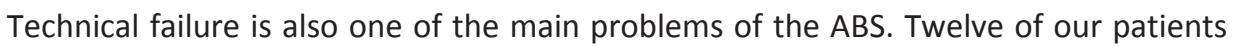

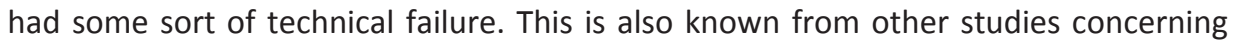

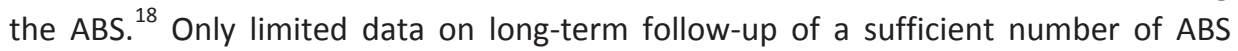

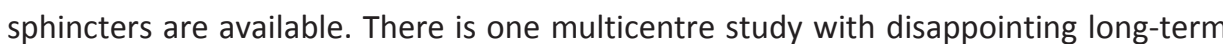

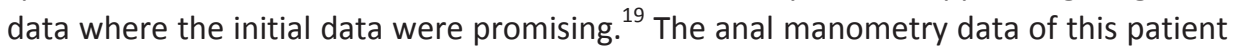

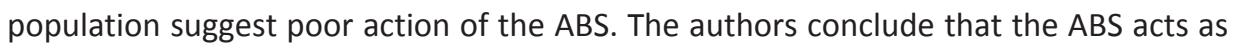

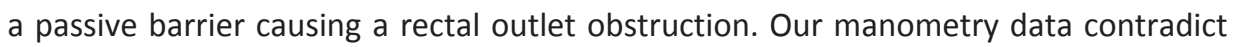

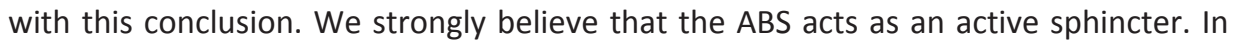

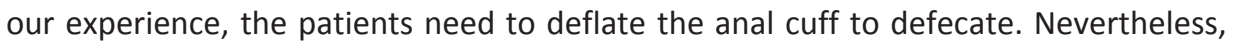

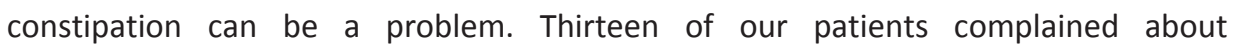

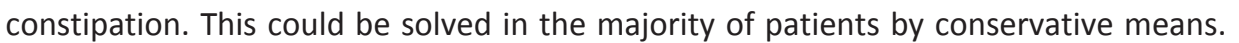

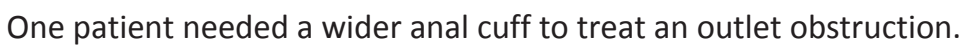

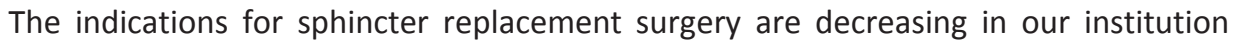

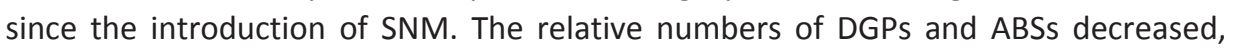

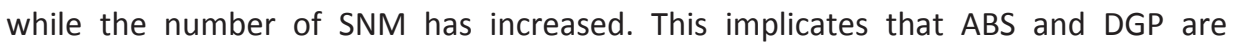
অ:

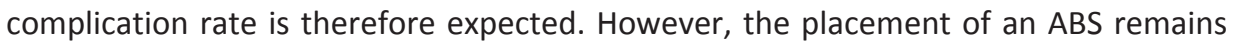

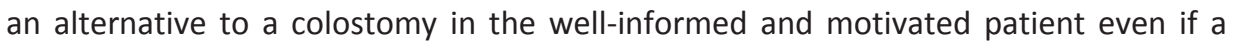

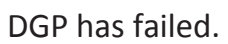




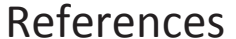

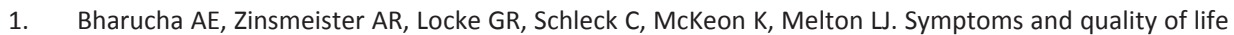

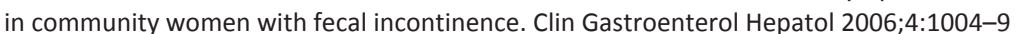

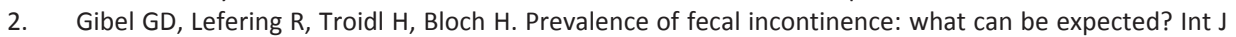

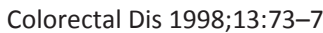

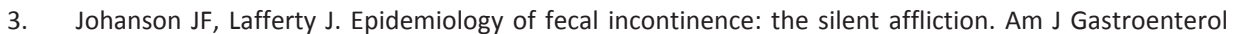

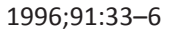

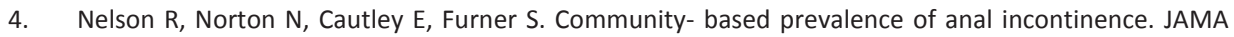

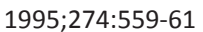

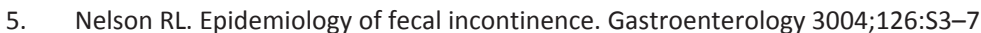

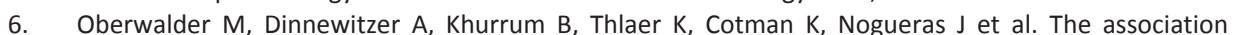

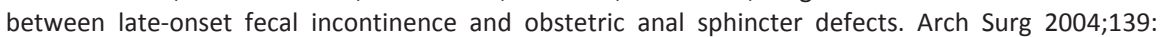
?:? ?:? ?

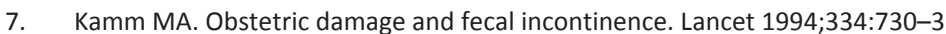

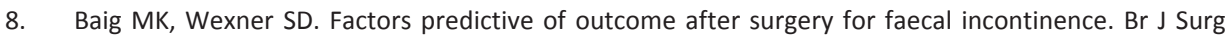

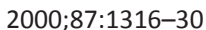

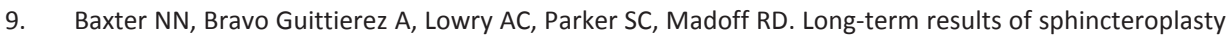

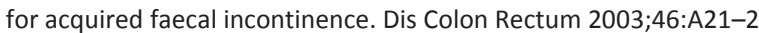

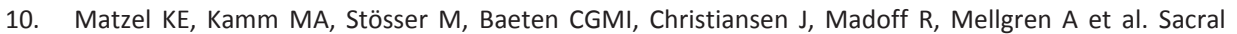

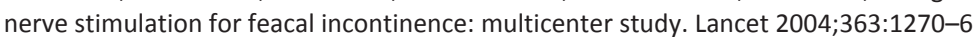

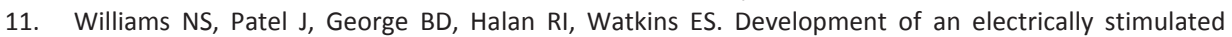

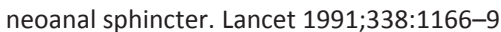

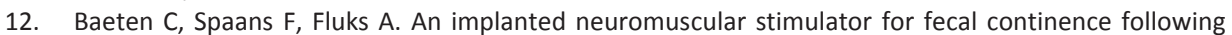

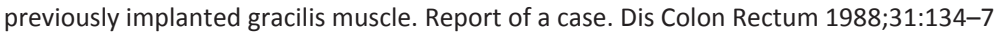

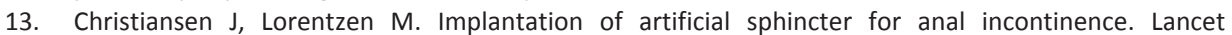

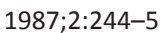

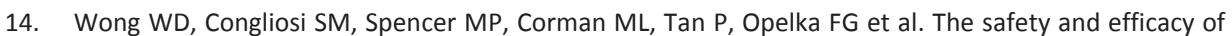

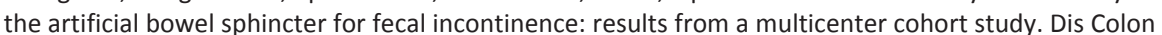

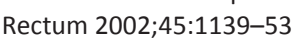

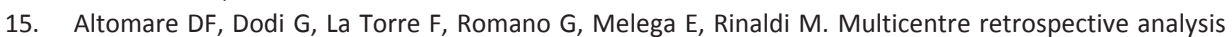

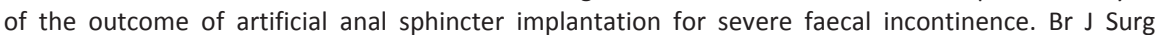

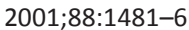

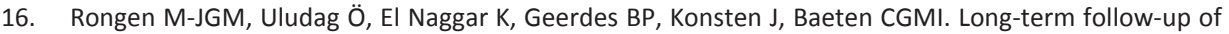

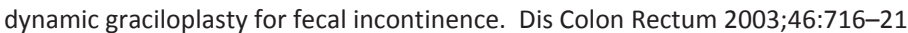

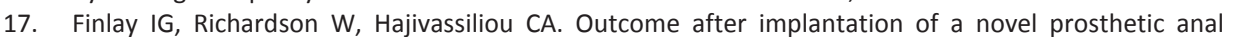

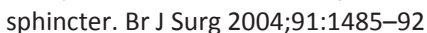

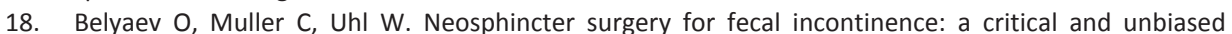

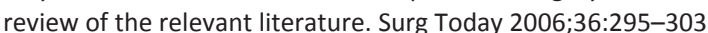

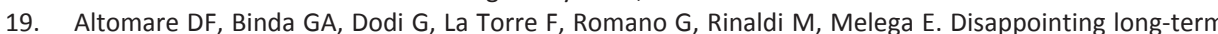

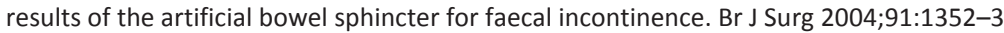




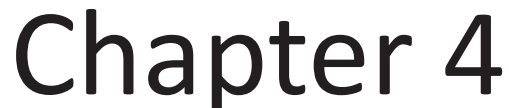

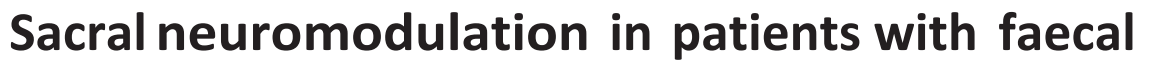

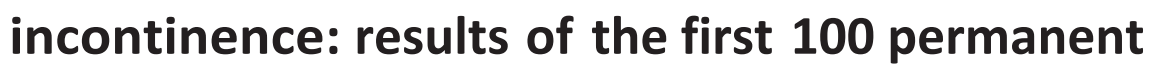

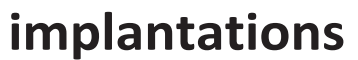

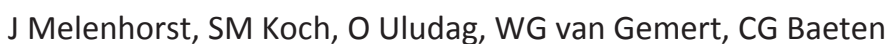

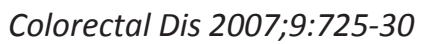




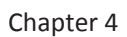

\section{?]?]?]?][?]?]}

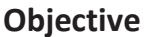

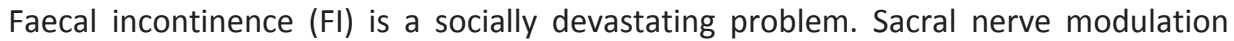

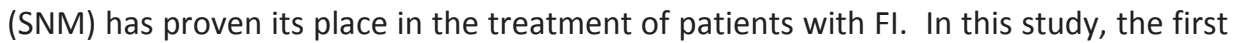

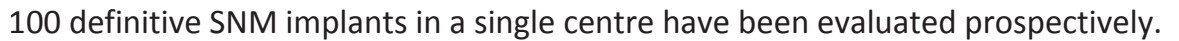

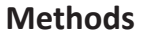

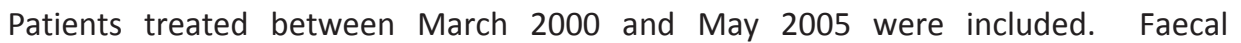

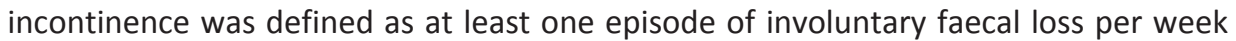

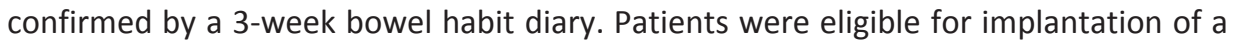

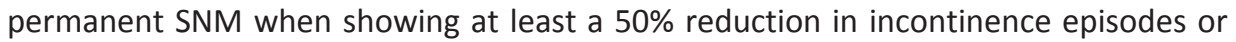

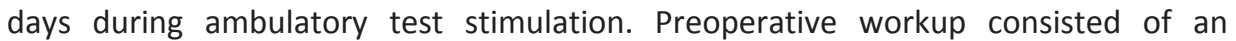

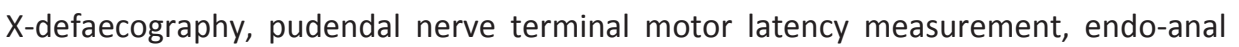

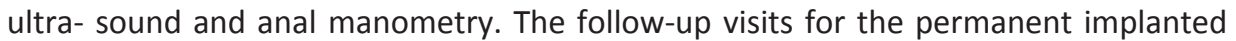

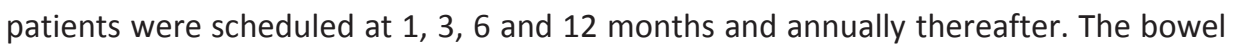

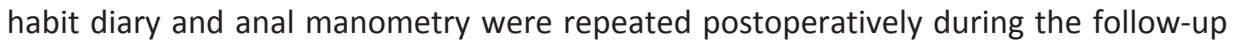

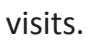

\section{回回回? 震}

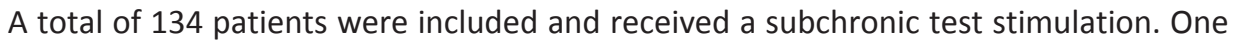

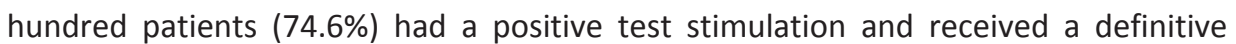

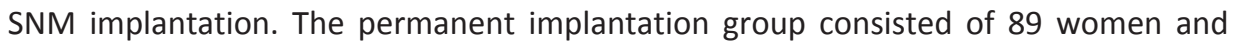

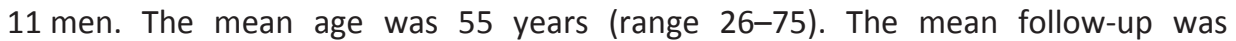

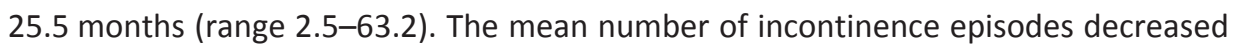

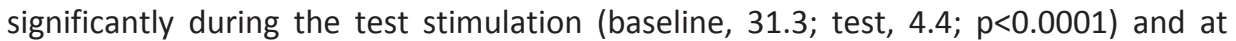

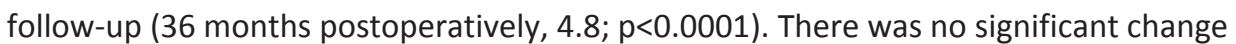

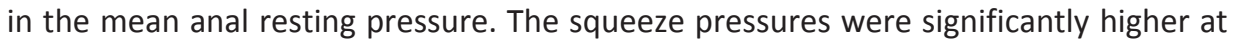

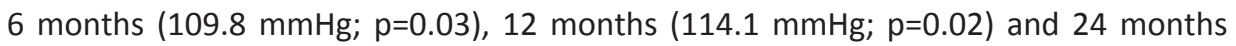

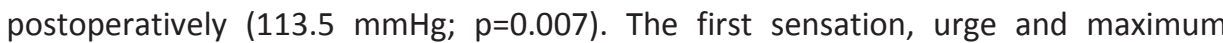

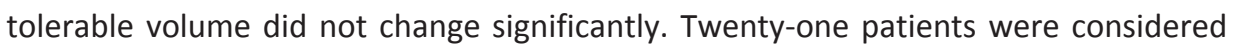

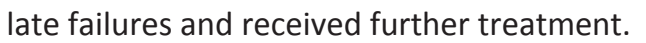

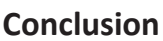

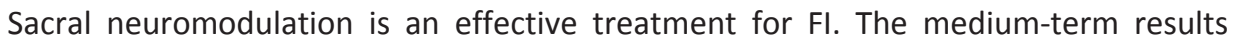

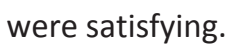




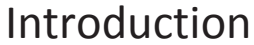

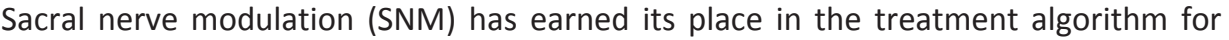

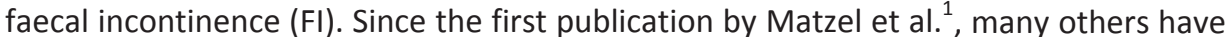

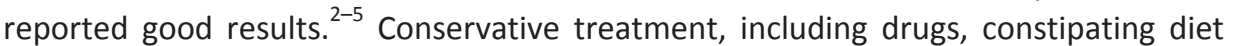

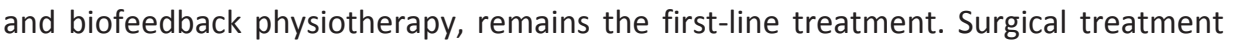

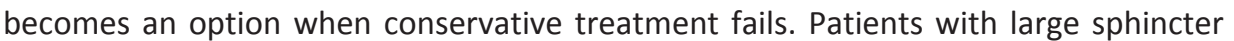

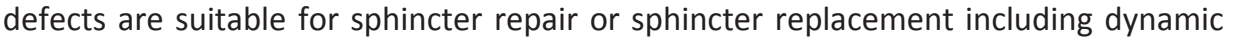

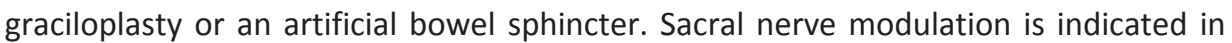

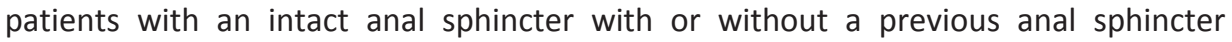

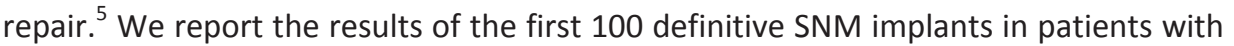

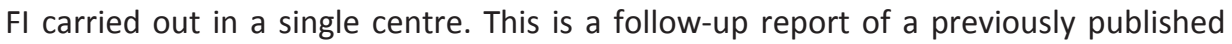

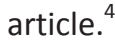

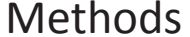

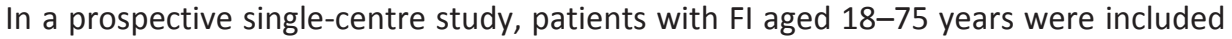

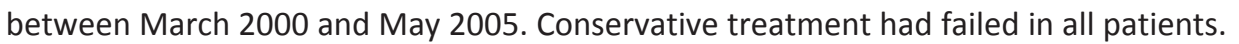

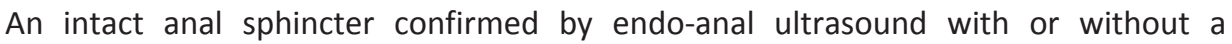

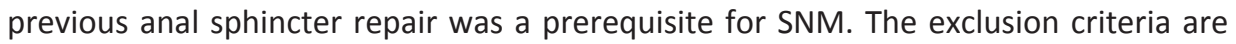

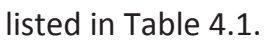

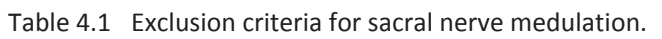

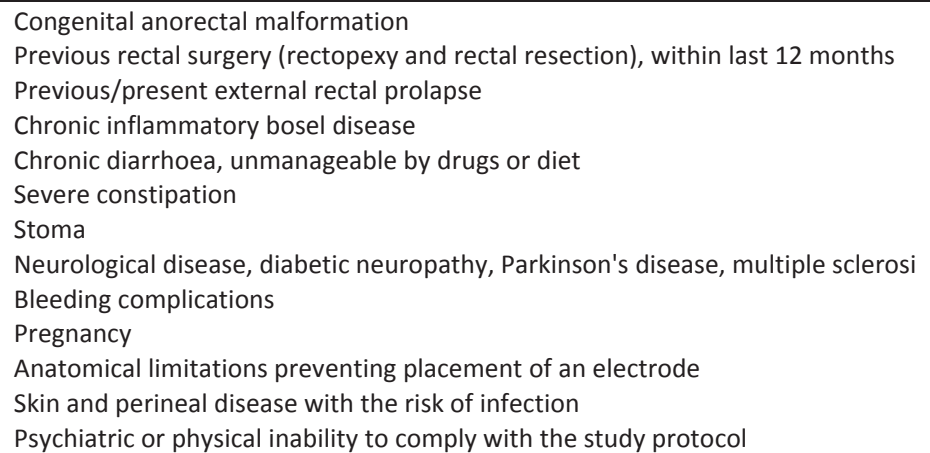

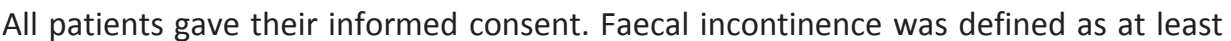

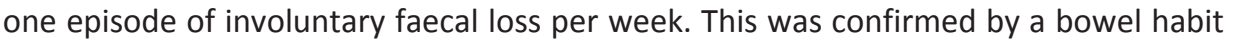

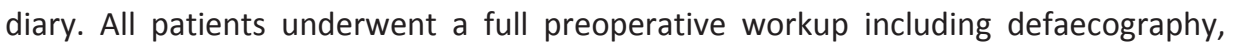

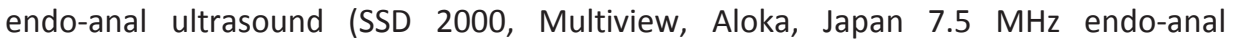

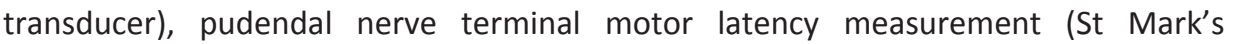

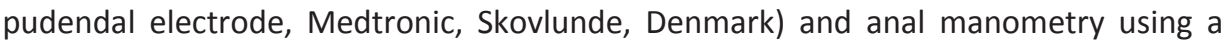




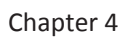

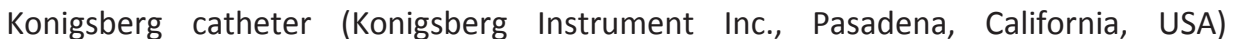

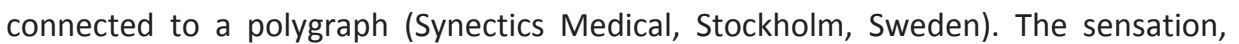
[?]

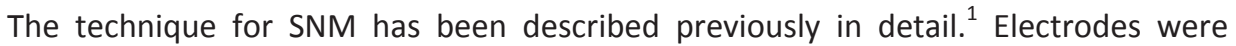

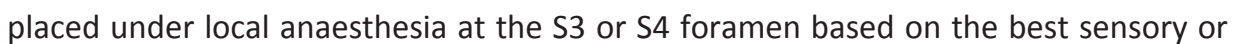

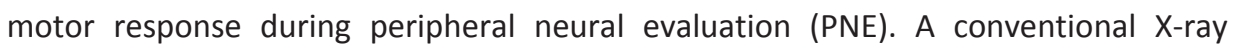

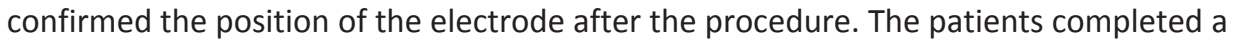

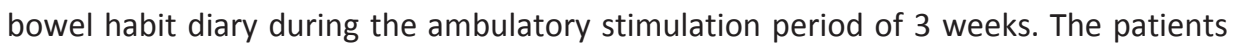

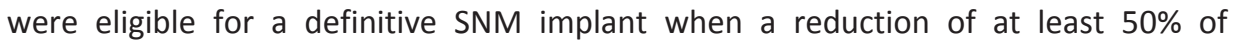

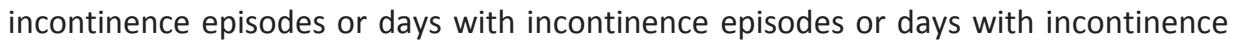

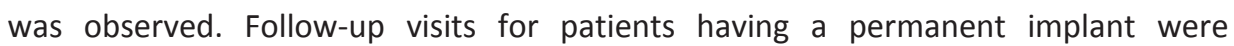

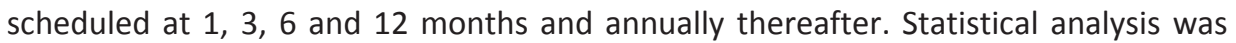

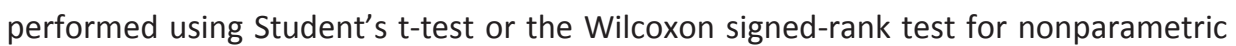

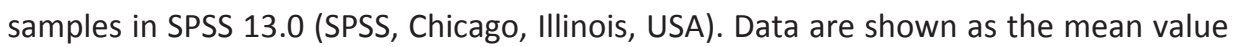

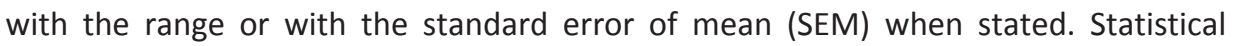

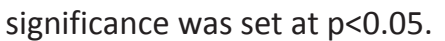

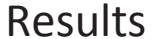

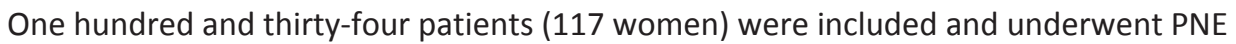

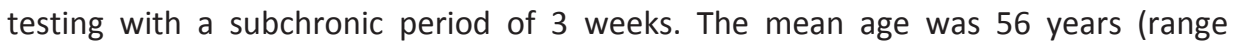

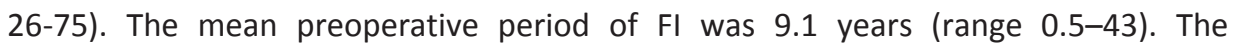

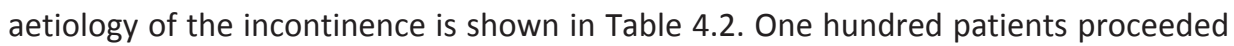

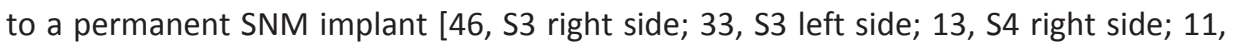

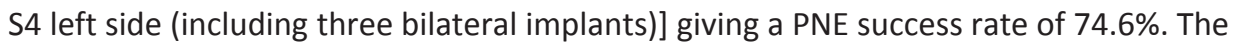

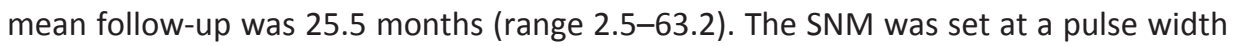

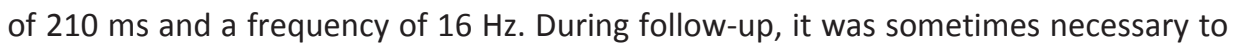

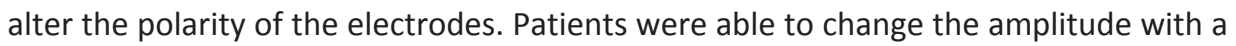

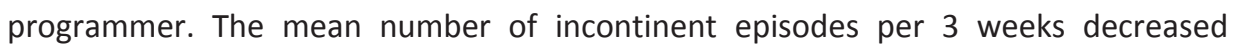

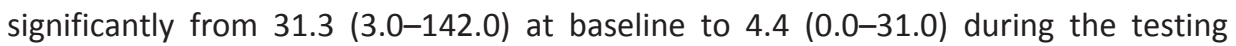

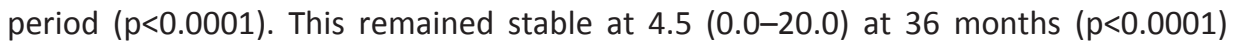

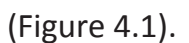

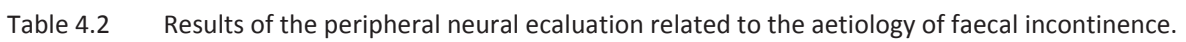

\begin{tabular}{|c|c|c|c|}
\hline \multirow[b]{2}{*}{ 回隽雨 } & \multicolumn{3}{|c|}{ 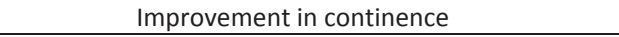 } \\
\hline & ??]?? & ??]??] & 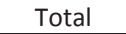 \\
\hline 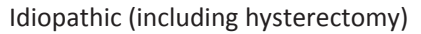 & 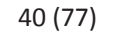 & ?]? & ??] \\
\hline 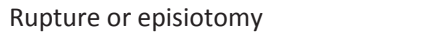 & 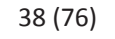 & ?]?] & ??? \\
\hline 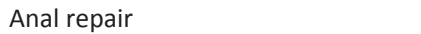 & ?]? 囦? & ? & ?]?] \\
\hline 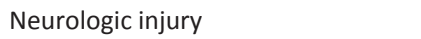 & 回 匪? ? & ? & ?]? \\
\hline 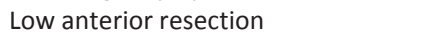 & 回国阳? & 回 & 回 \\
\hline ?]?] ?]? & 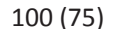 & 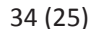 & 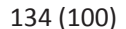 \\
\hline
\end{tabular}

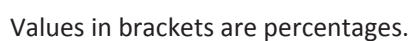




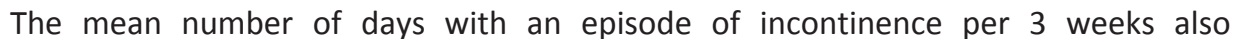

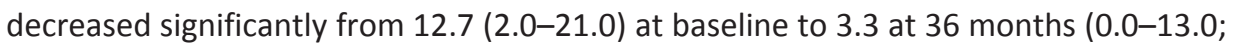

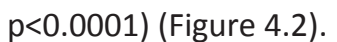

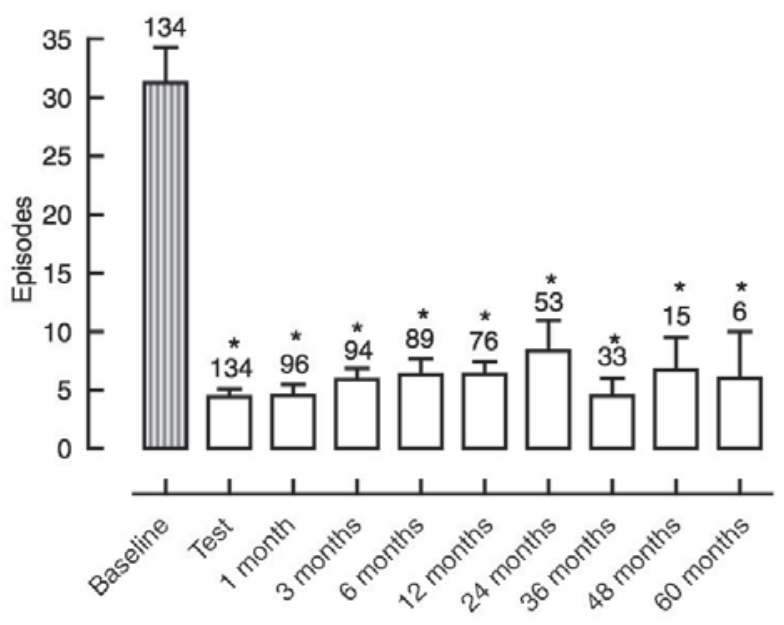

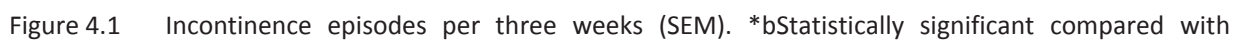

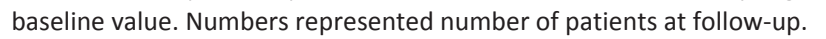

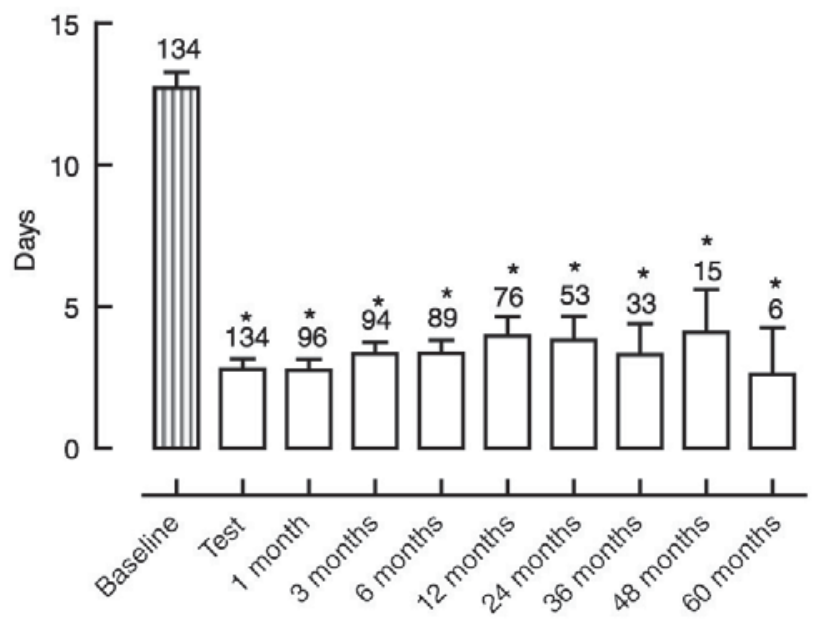

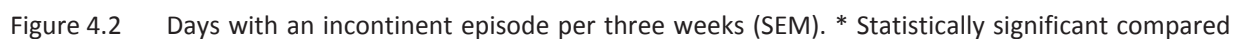

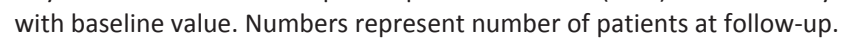




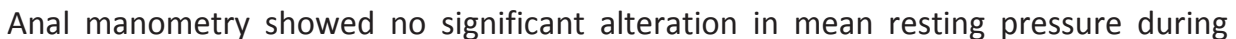

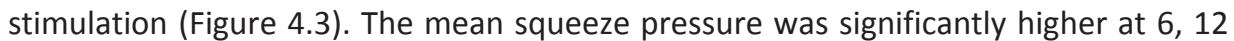

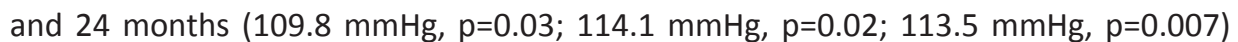

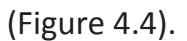

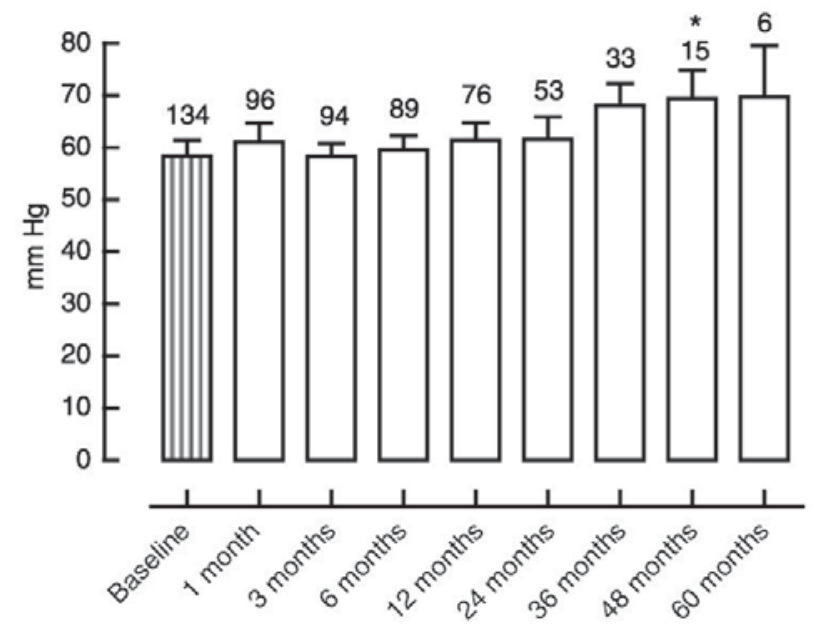

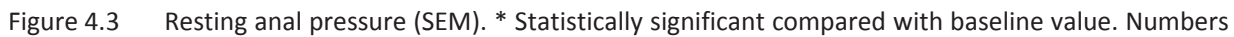

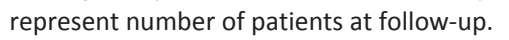

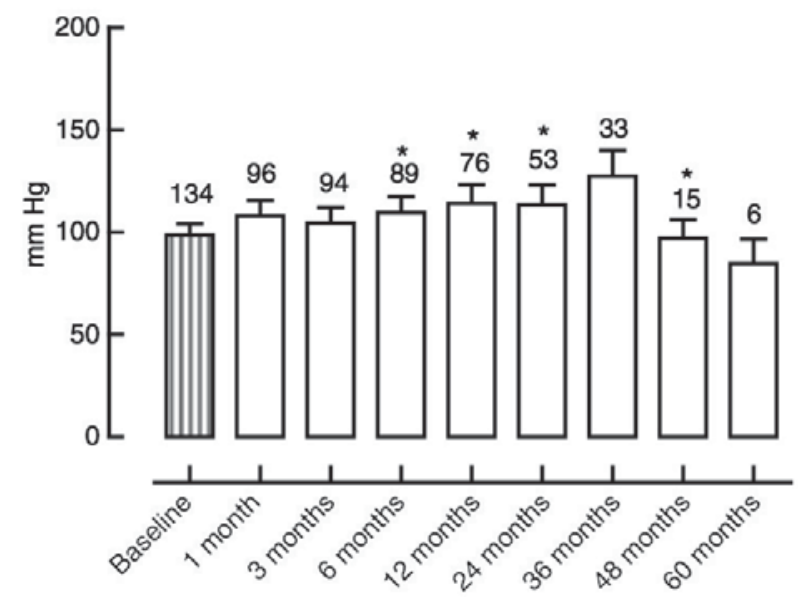

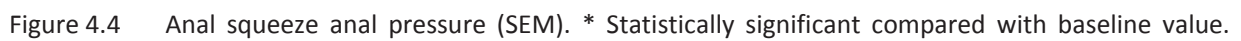

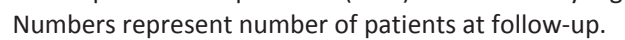




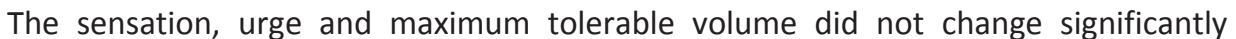

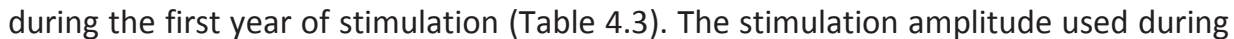

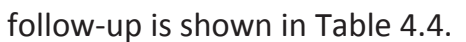

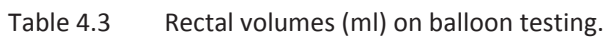

\begin{tabular}{|c|c|c|c|}
\hline & 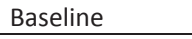 & 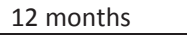 & ?]-?]?]? ? \\
\hline 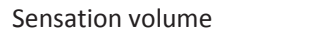 & 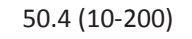 & 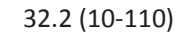 & 国承回 \\
\hline 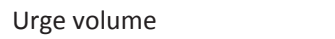 & 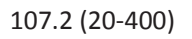 & 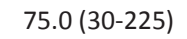 & 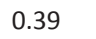 \\
\hline 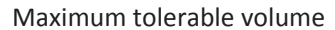 & 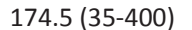 & 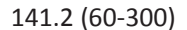 & ?]द्? \\
\hline
\end{tabular}

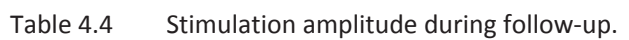

\begin{tabular}{|c|c|c|c|c|c|c|c|}
\hline & 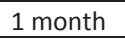 & 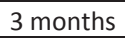 & 圆圆 回回雨? & 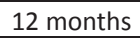 & 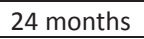 & 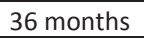 & 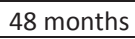 \\
\hline \multirow[t]{2}{*}{ 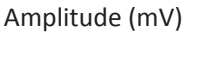 } & 国阿 & 国侓 & 国耶 & 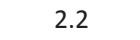 & 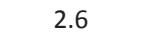 & 国侓 & ? 国阿 \\
\hline & 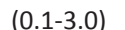 & 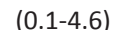 & 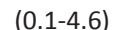 & 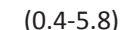 & 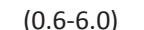 & 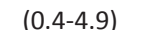 & 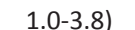 \\
\hline
\end{tabular}

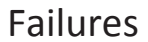

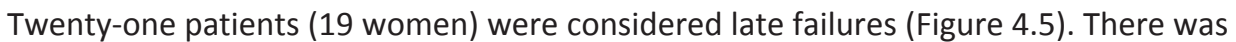

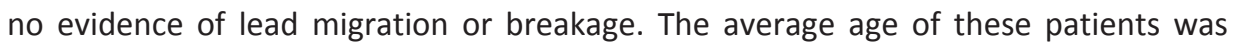

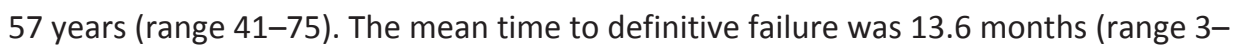

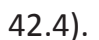

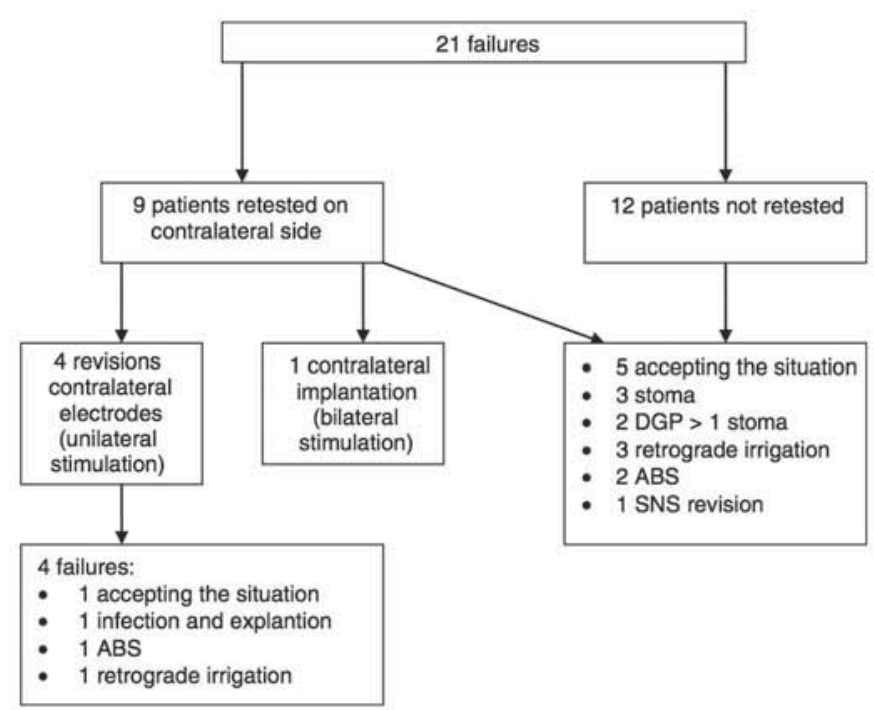

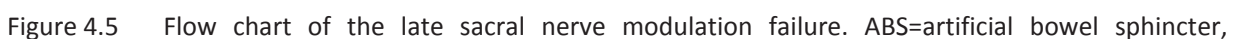

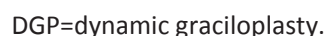




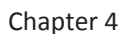

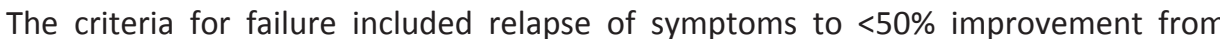

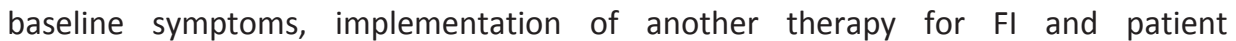

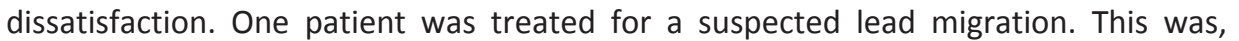

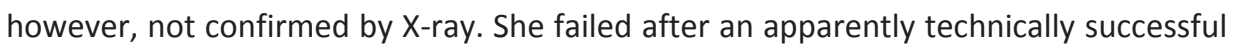

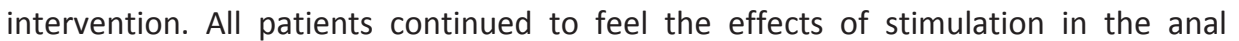

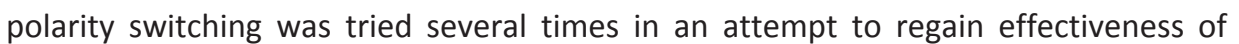

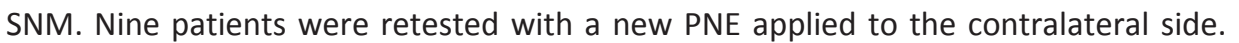

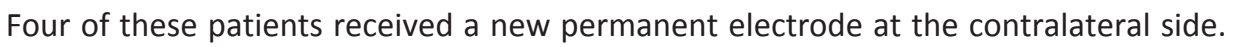

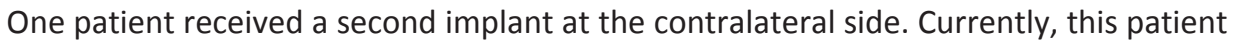

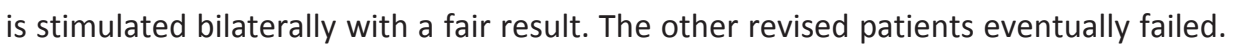

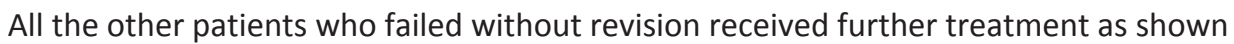

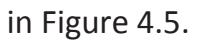

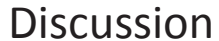

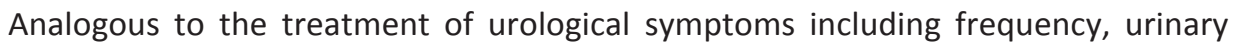

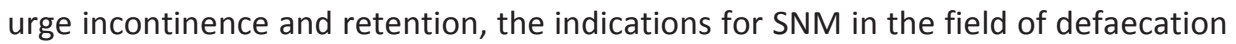

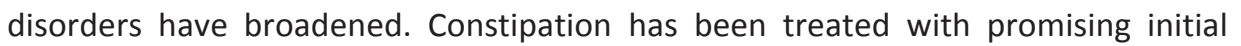

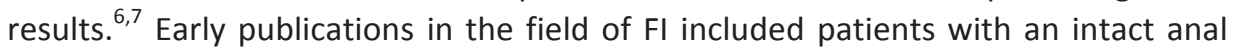

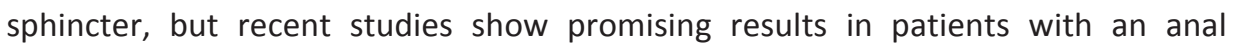

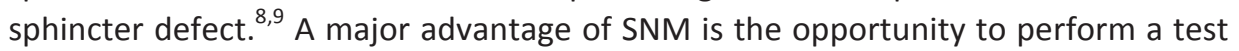

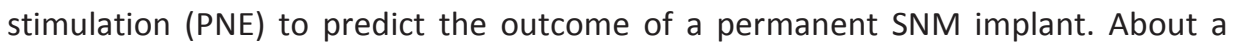

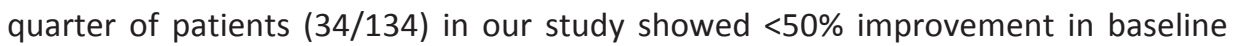

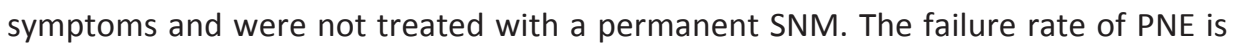

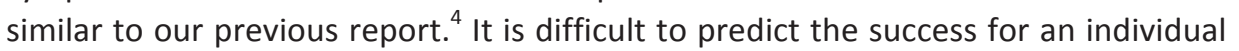

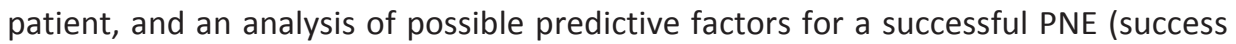

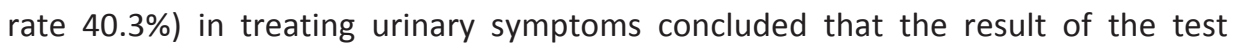

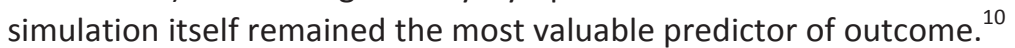

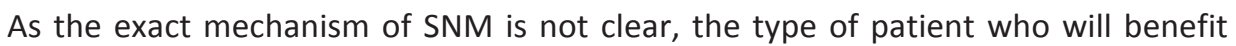

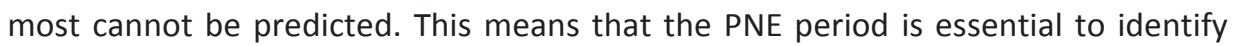

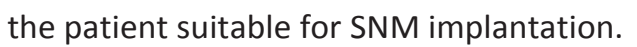

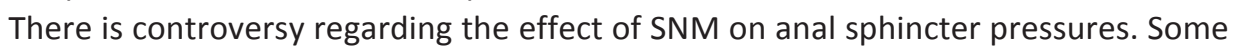

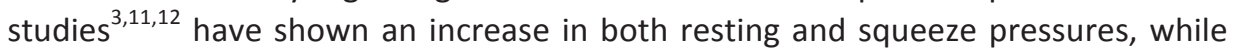

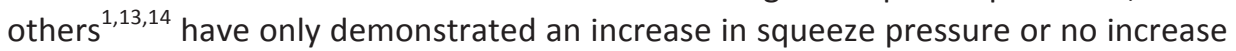

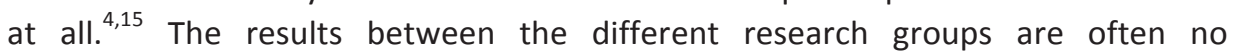

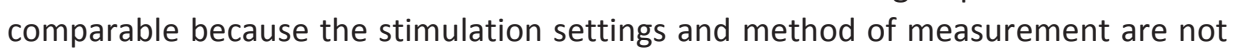

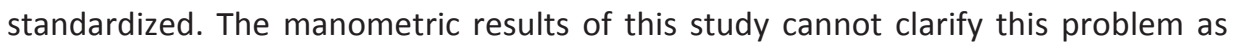

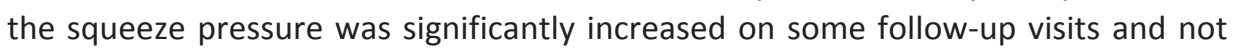

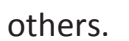

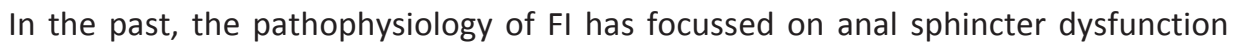

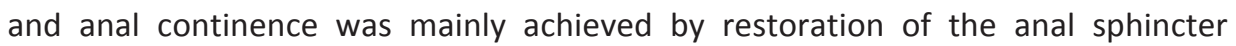




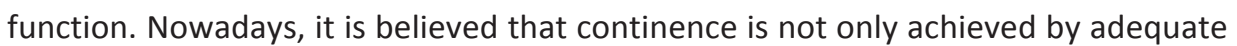

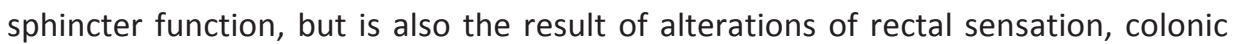

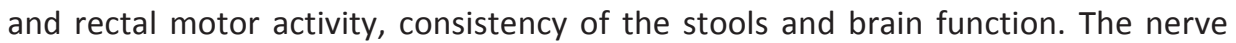

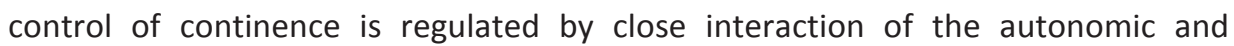

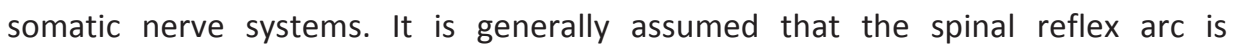

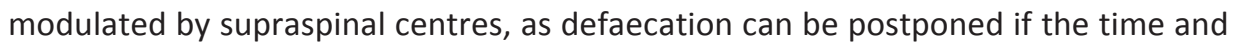

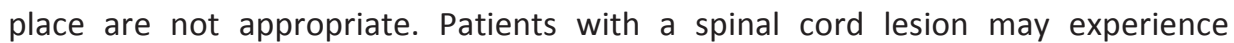

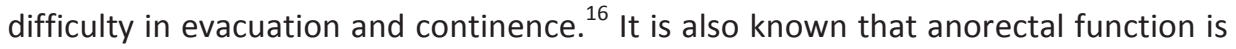

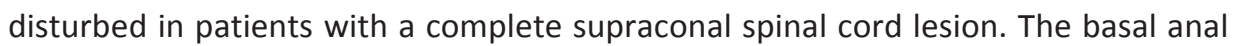

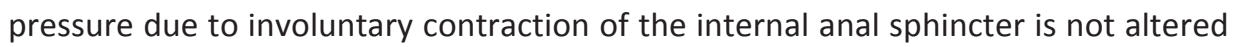

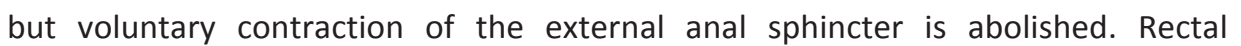

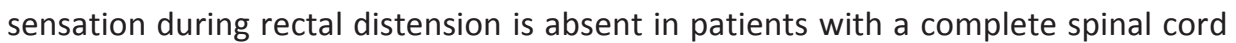

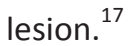

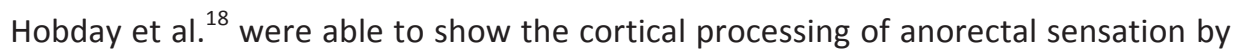

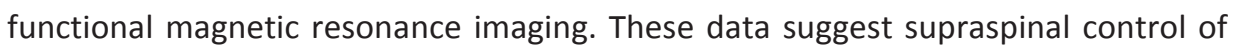

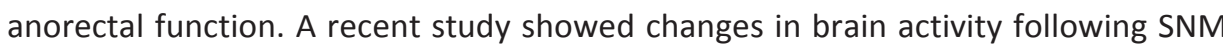

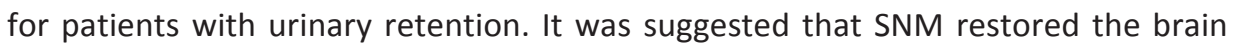

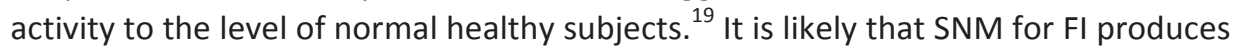

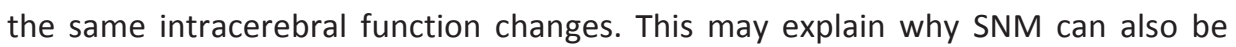

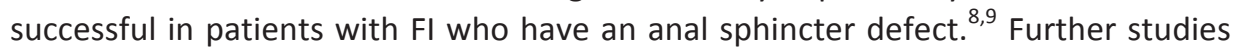

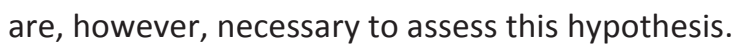

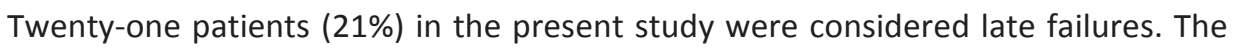

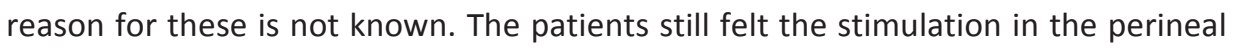

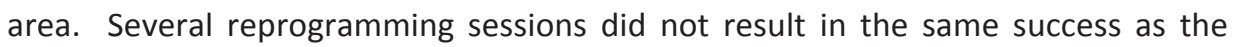

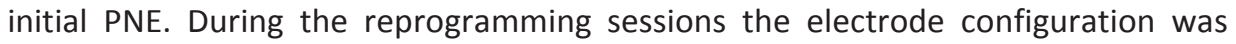

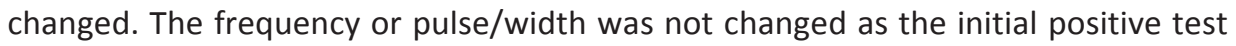

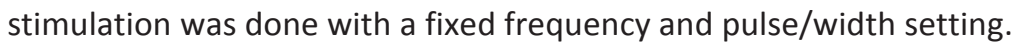

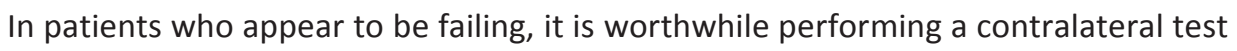

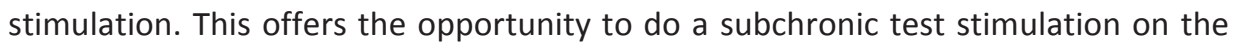

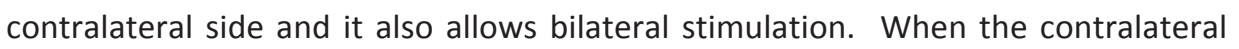

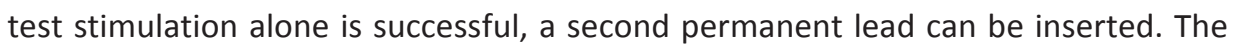

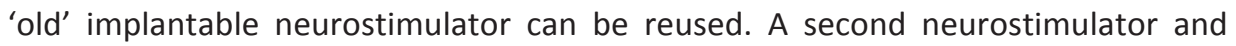
[50

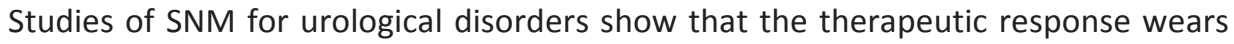

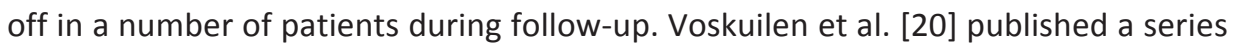

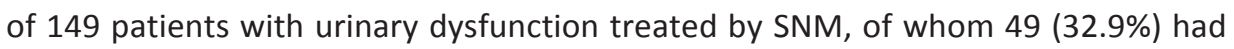

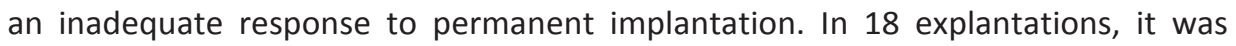

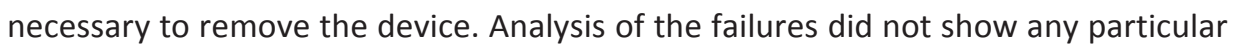

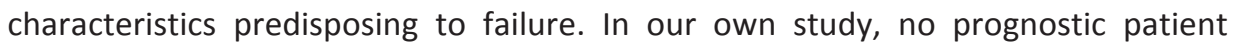

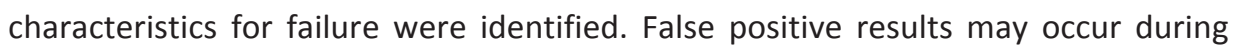

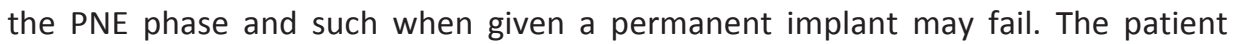




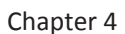

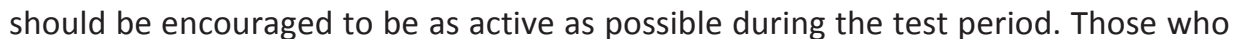

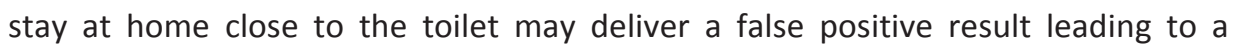

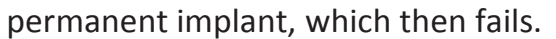

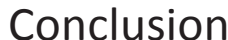

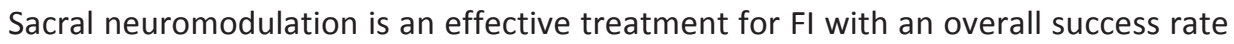

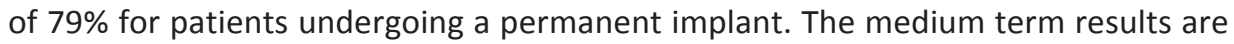

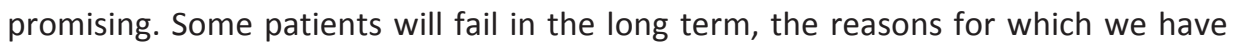

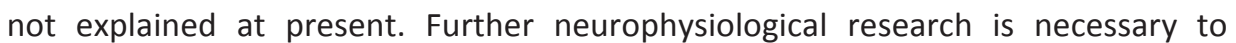

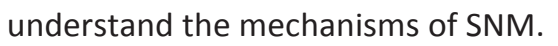




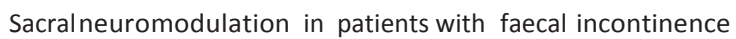

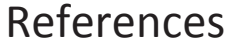

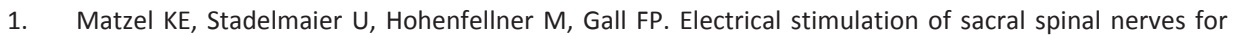

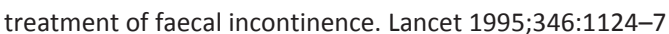

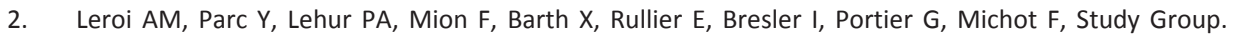

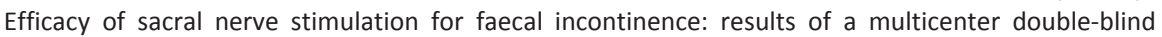

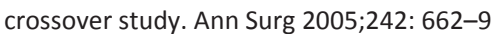

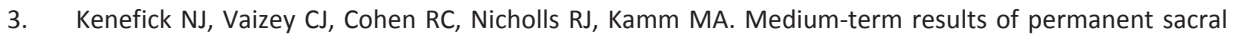

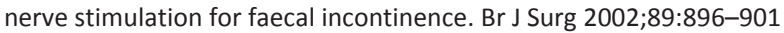

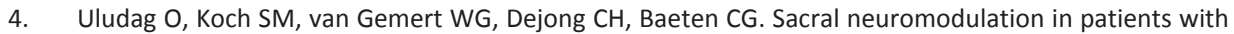

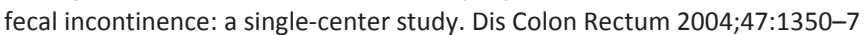

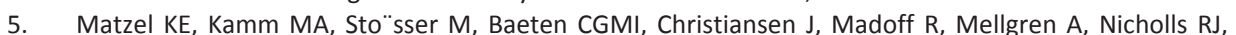

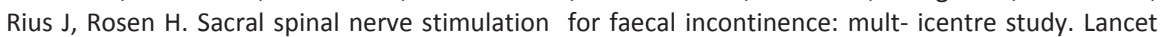

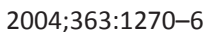

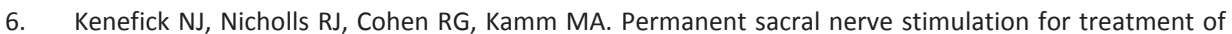

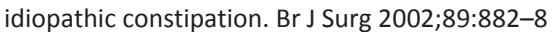

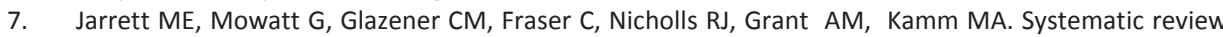

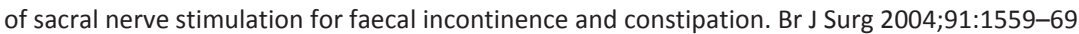

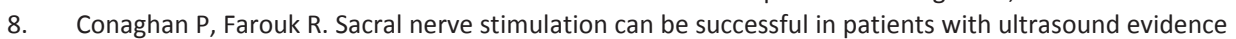

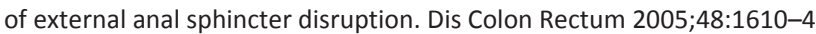

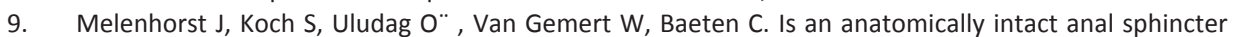

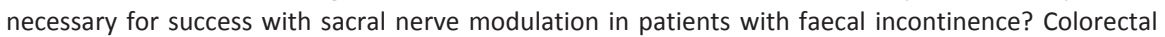

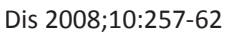

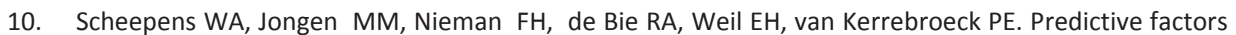

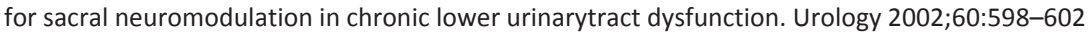

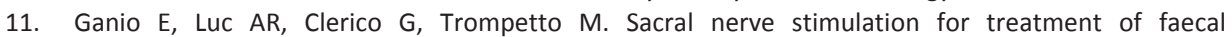

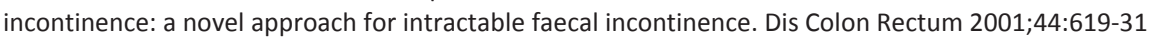

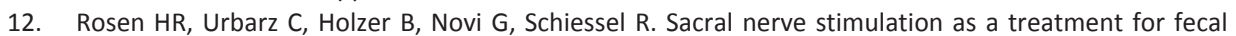

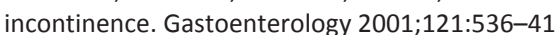

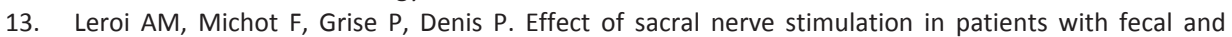

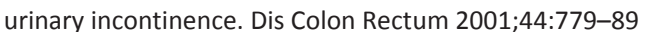

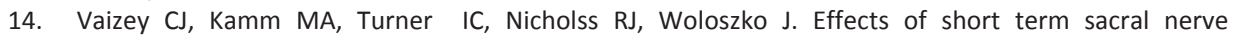

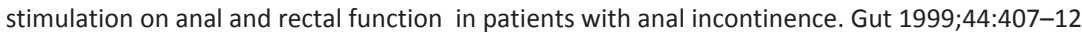

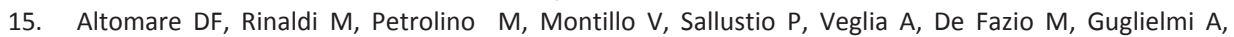

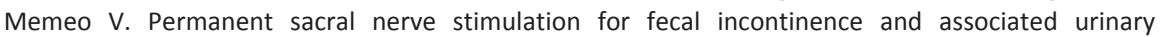

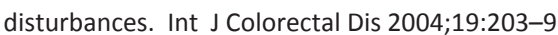

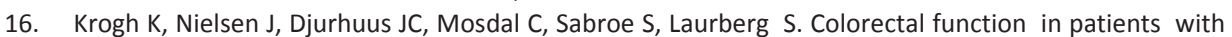

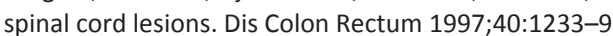

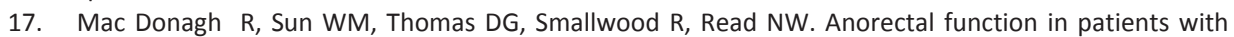

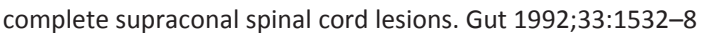

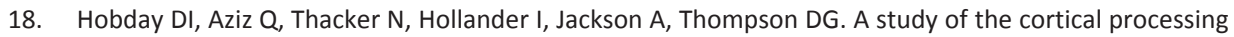

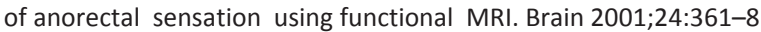

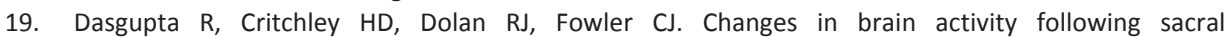

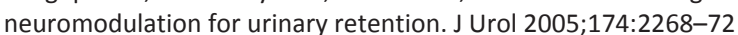

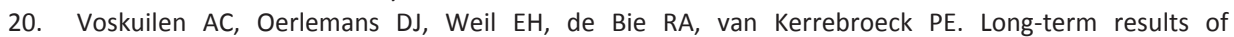

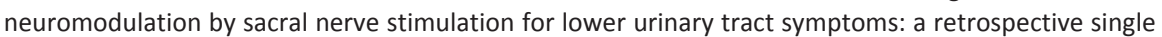

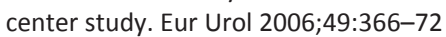




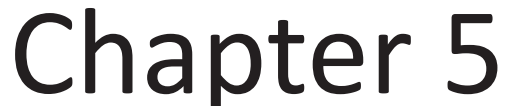

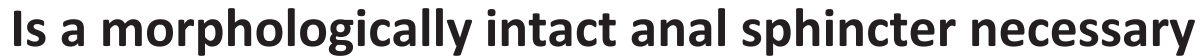

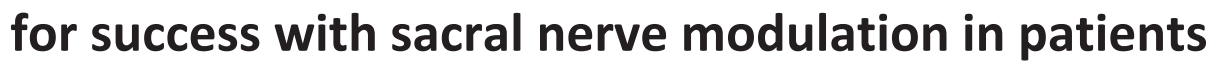

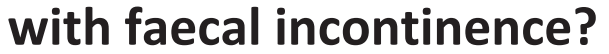

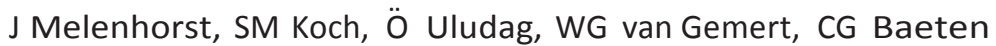

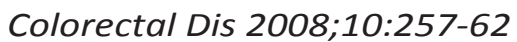




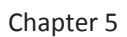

\section{?]?]?][?]?]?}

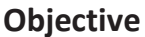

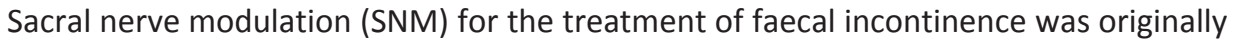

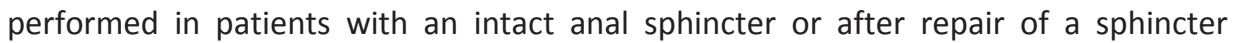

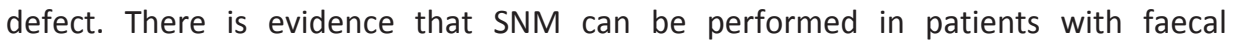

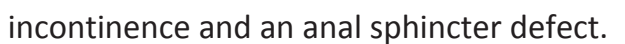

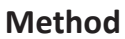

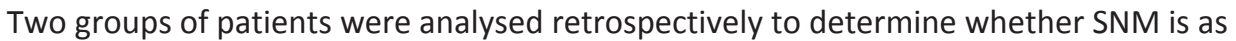

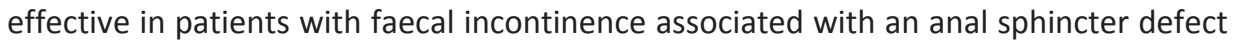

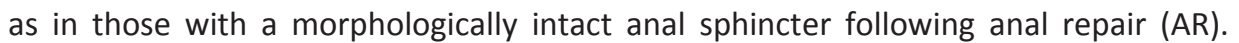

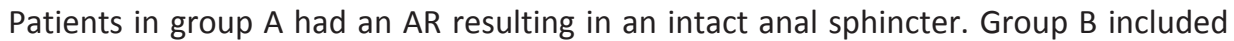

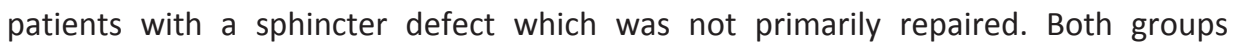

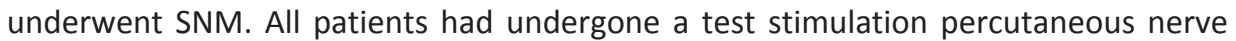

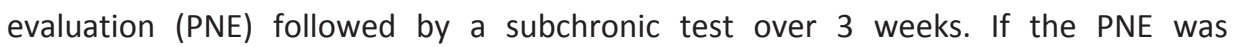

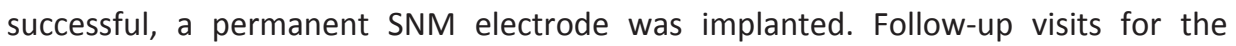

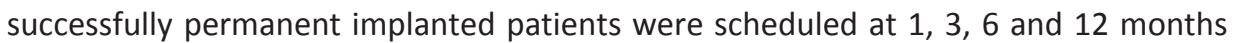

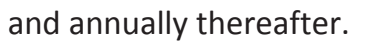

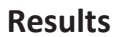

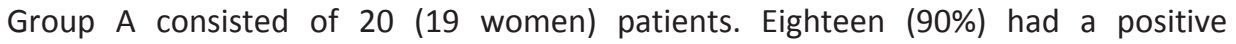

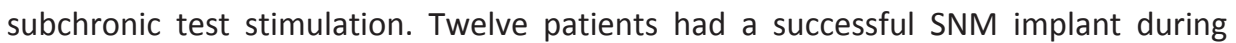

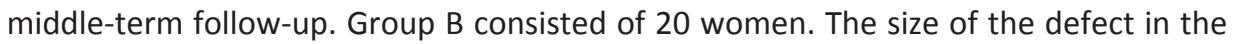

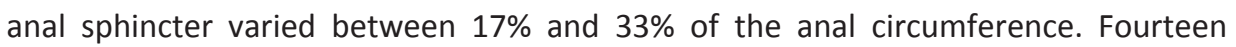

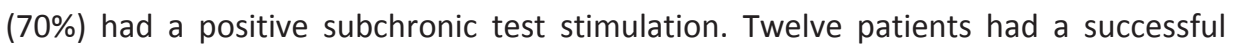

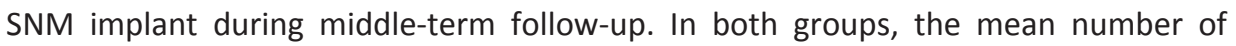

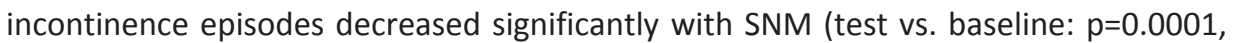

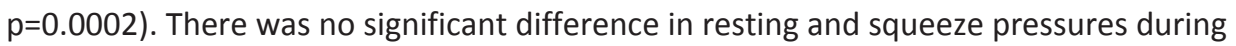

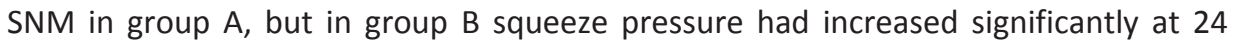

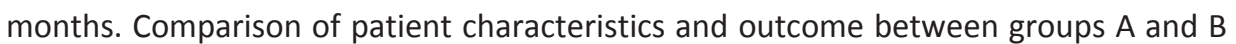

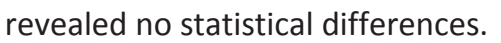

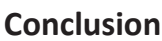

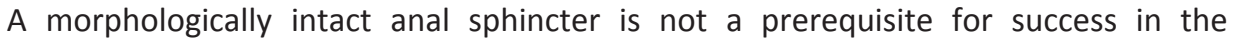

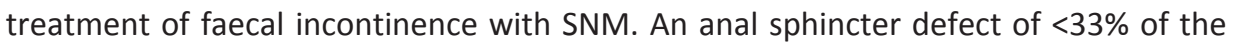

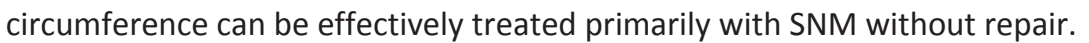




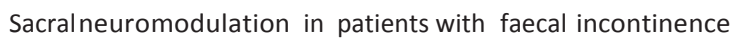

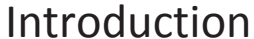

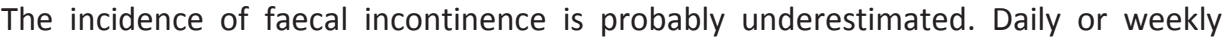

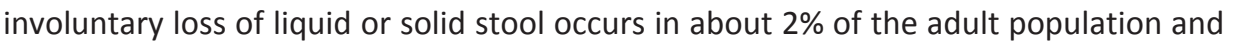

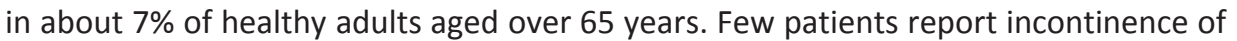

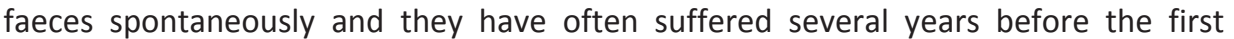

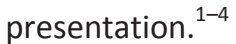

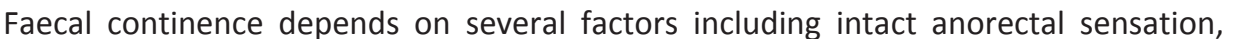

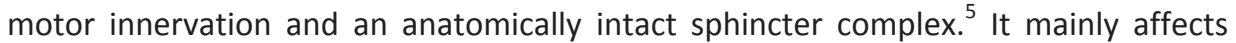

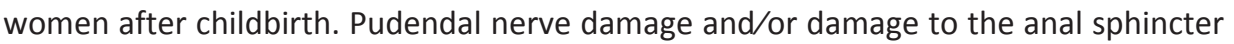

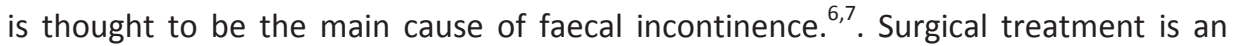

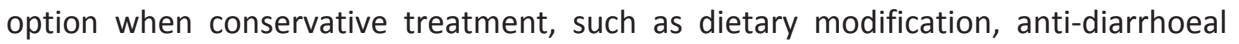

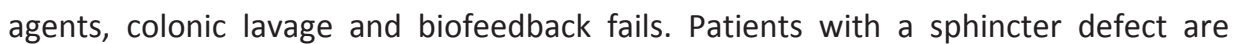

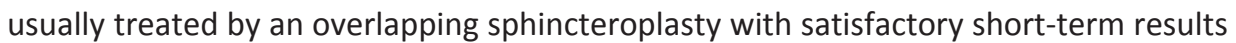

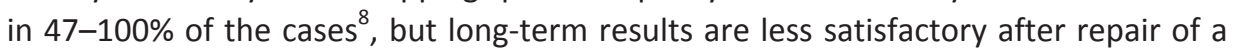

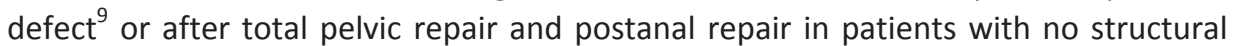

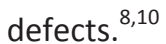

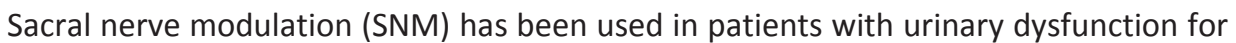

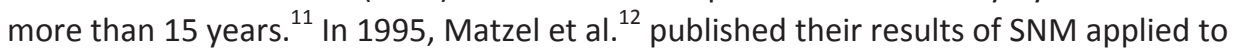

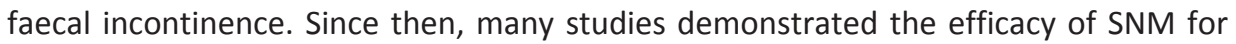

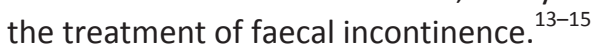

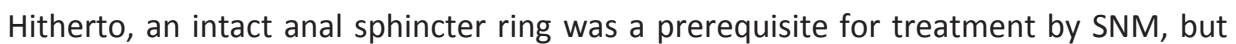

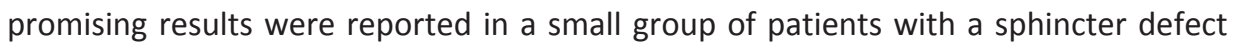

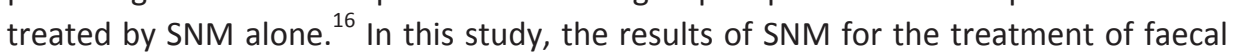

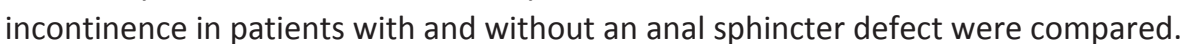

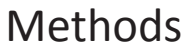

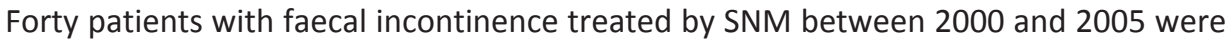
[5

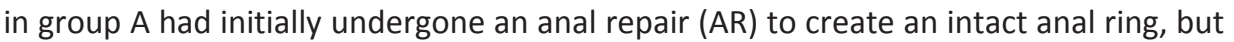

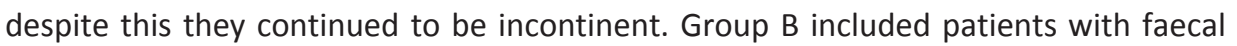

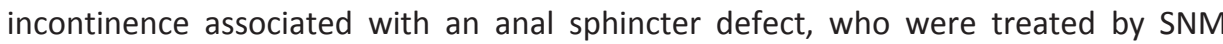

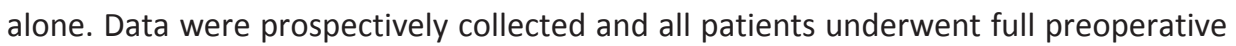

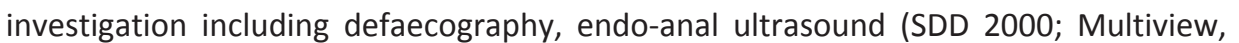

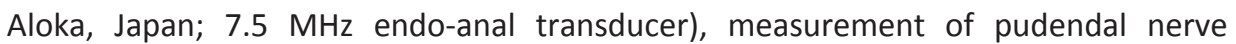

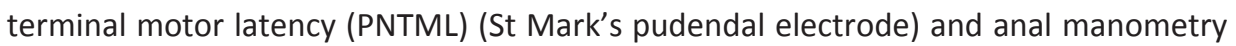

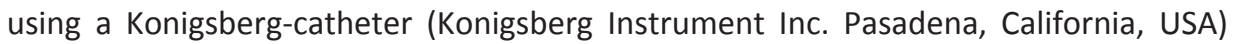

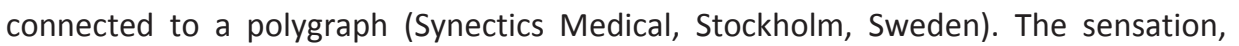

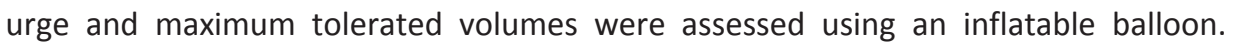




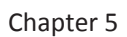

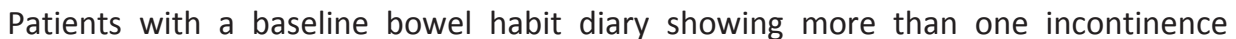

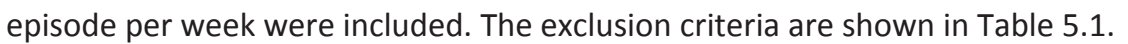

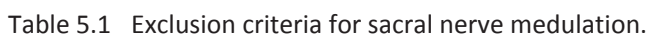

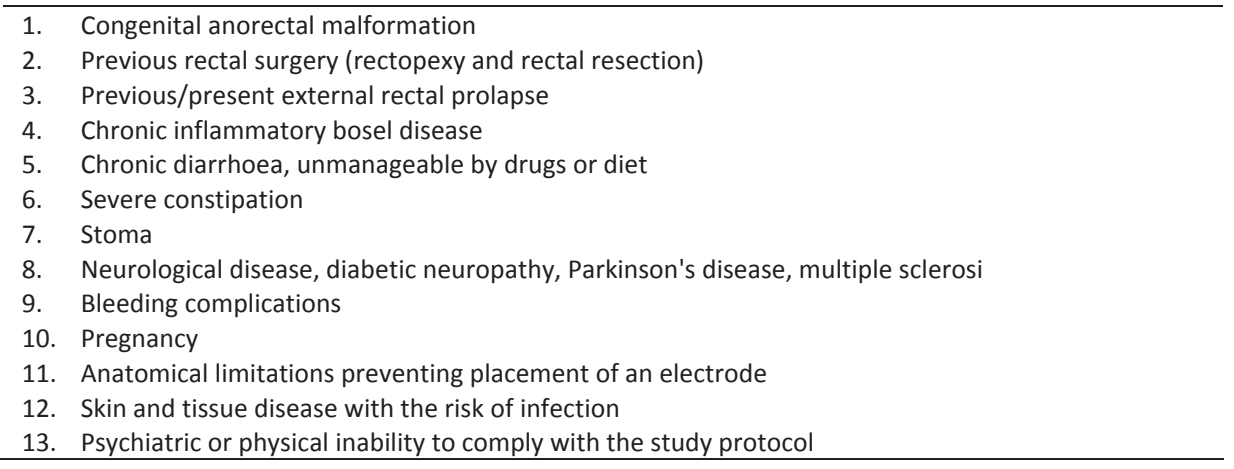

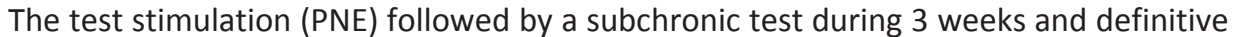

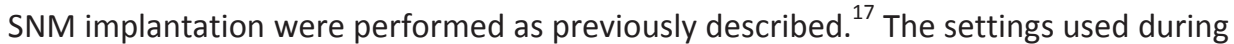

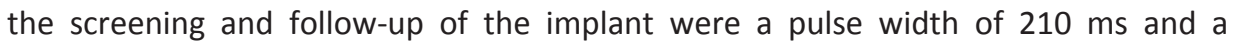

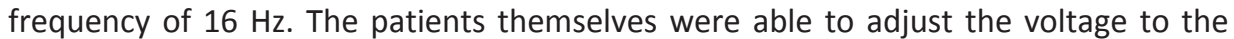

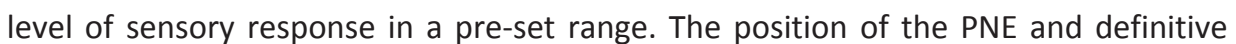

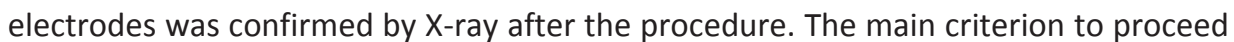

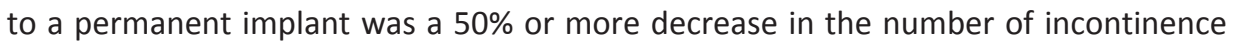

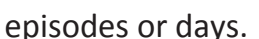

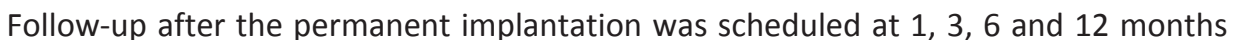

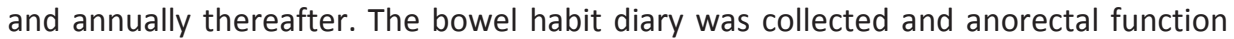

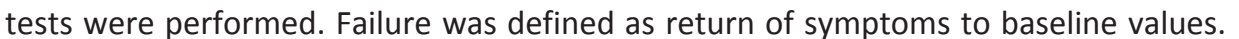

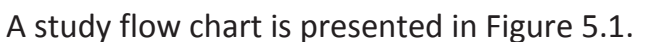

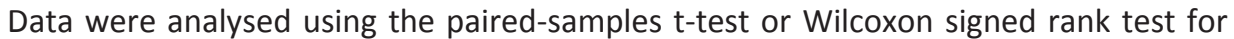

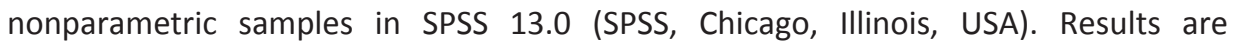

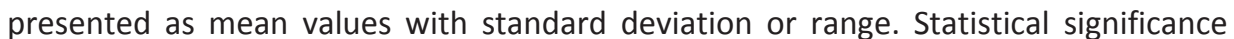

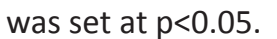



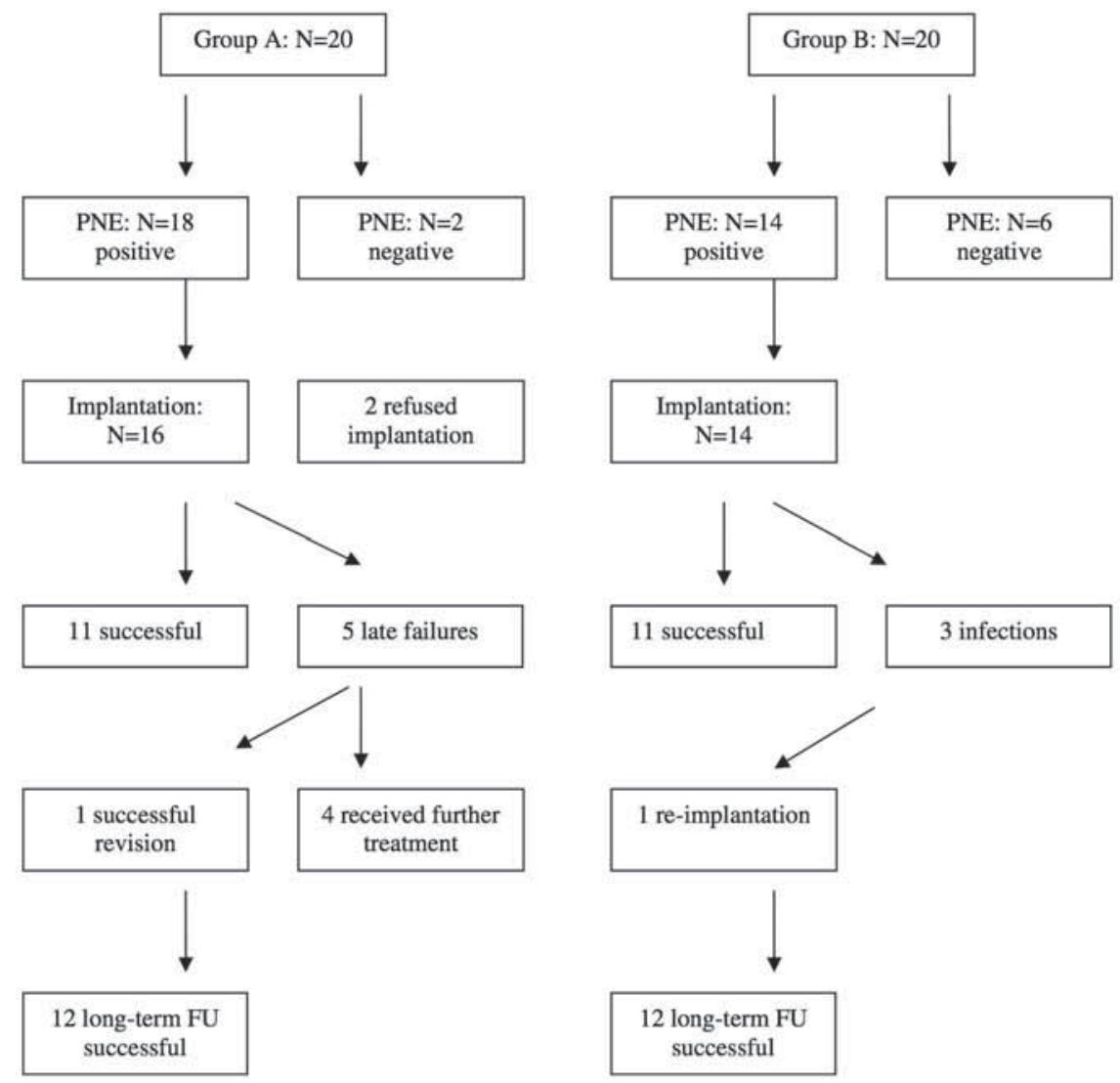

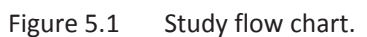

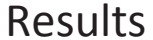

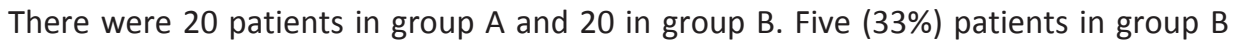

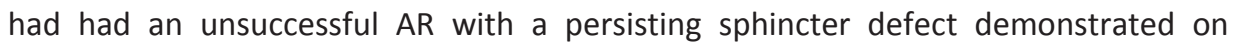

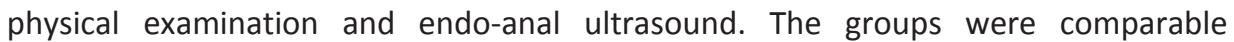

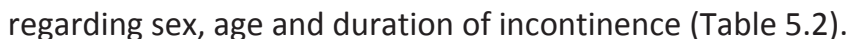




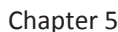

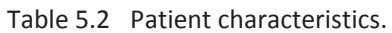

\begin{tabular}{|c|c|c|c|}
\hline & 国㕣? 圆 & 目雨? 圆 & 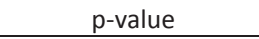 \\
\hline \multicolumn{4}{|l|}{ 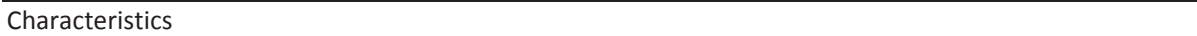 } \\
\hline 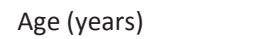 & 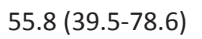 & 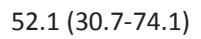 & 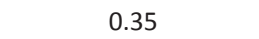 \\
\hline 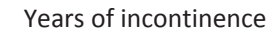 & 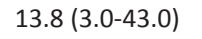 & 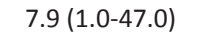 & ?[?] \\
\hline 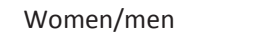 & 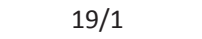 & 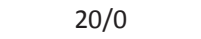 & \\
\hline 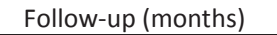 & 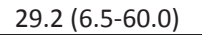 & 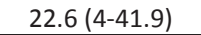 & 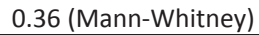 \\
\hline
\end{tabular}

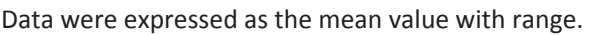

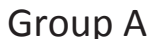

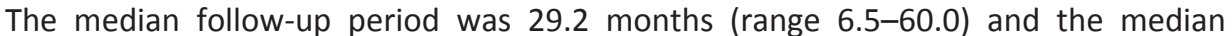

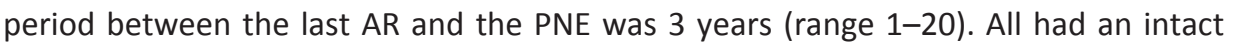

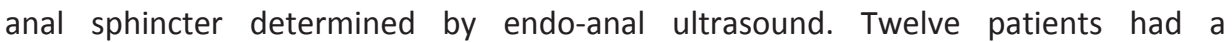

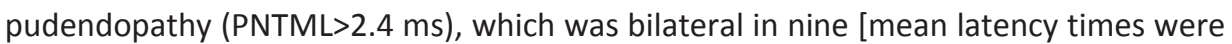

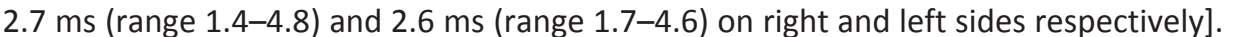

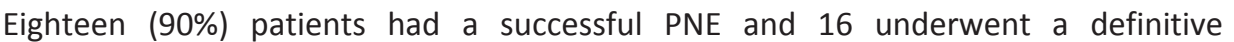

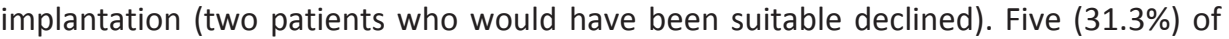

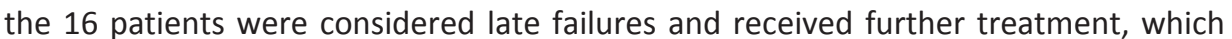
[5

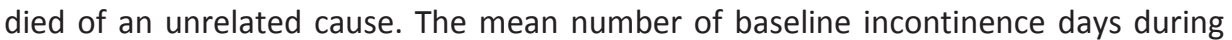

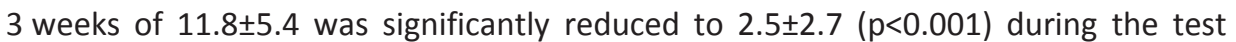
패

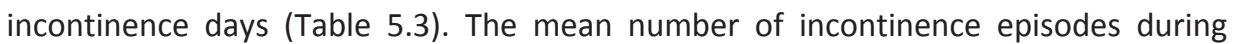

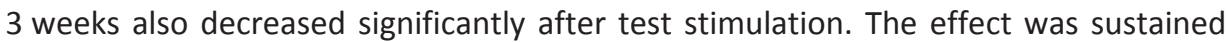

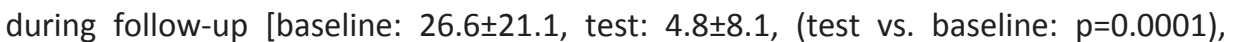

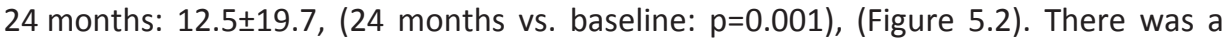

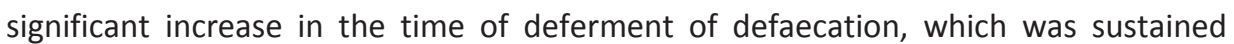

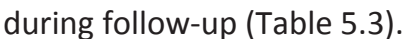

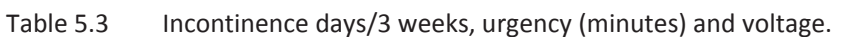

\begin{tabular}{|c|c|c|c|}
\hline & 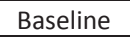 & 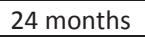 & ?]-?]?[?]? \\
\hline \multicolumn{4}{|l|}{ 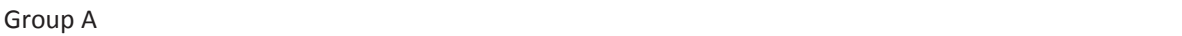 } \\
\hline 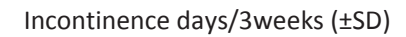 & 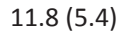 & 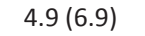 & ?]象? \\
\hline 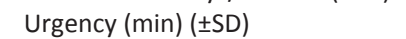 & 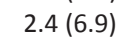 & 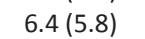 & 国到?]? \\
\hline 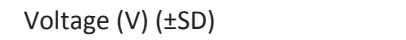 & 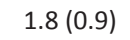 & 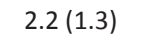 & ? 征? \\
\hline \multicolumn{4}{|l|}{ 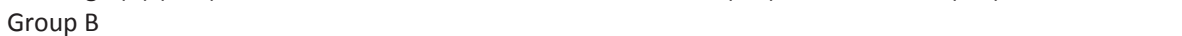 } \\
\hline 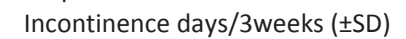 & 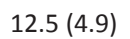 & 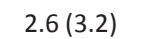 & 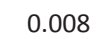 \\
\hline 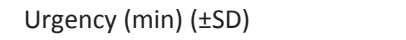 & 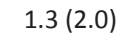 & 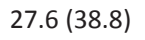 & 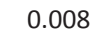 \\
\hline 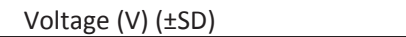 & 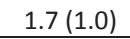 & 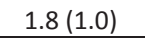 & ? 国韧? \\
\hline
\end{tabular}

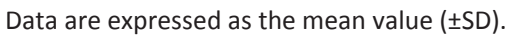




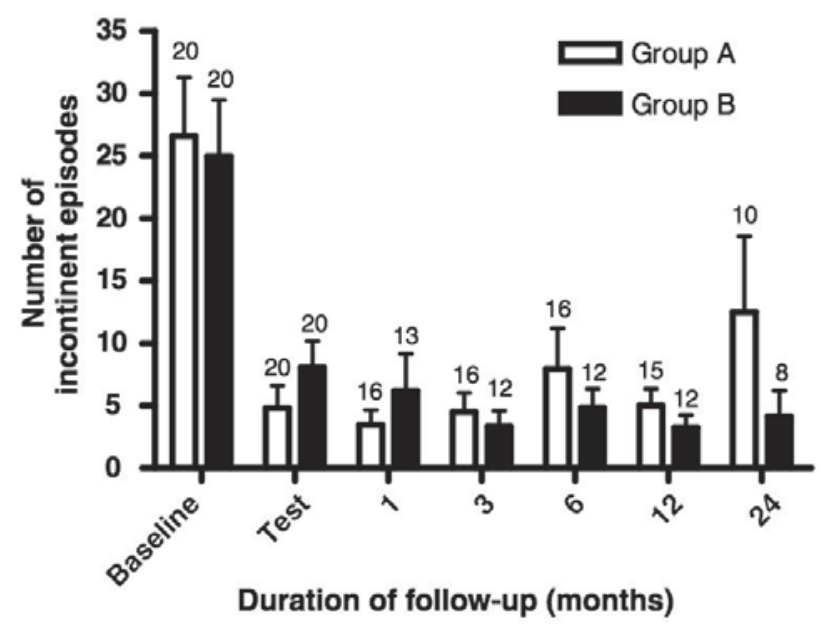

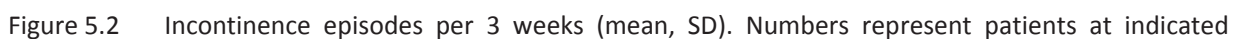

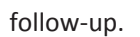

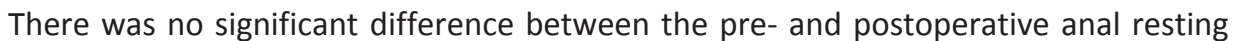

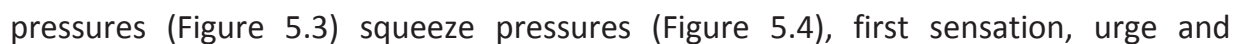

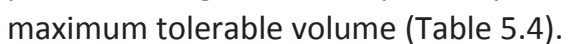

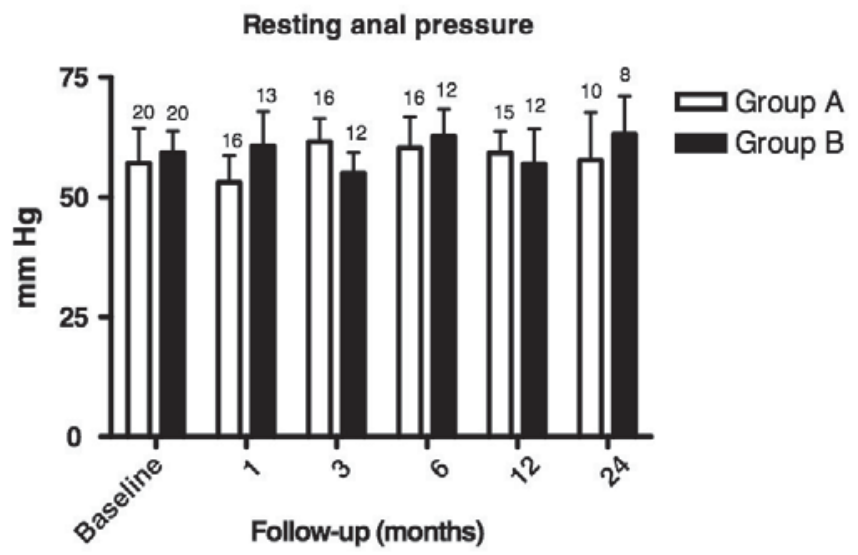

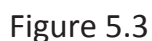

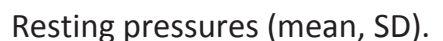




\section{Squeeze pressure}

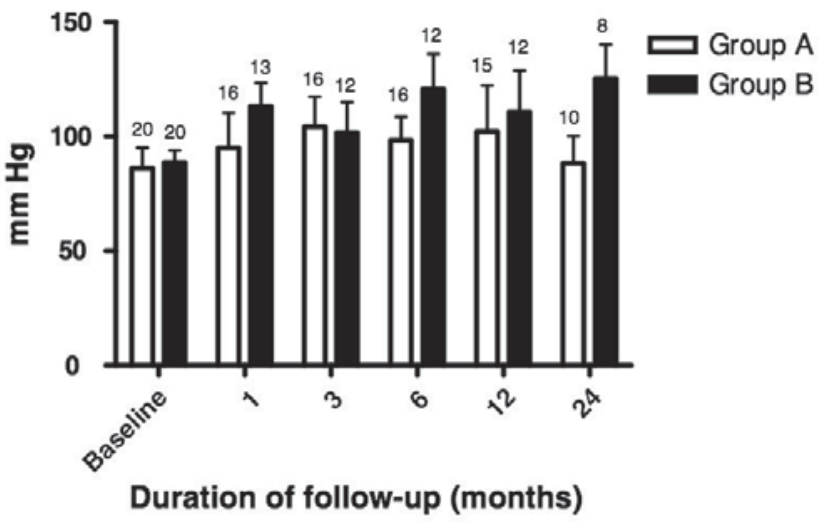

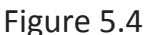

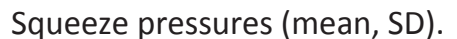

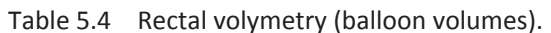

\begin{tabular}{|c|c|c|c|}
\hline 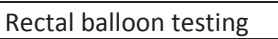 & 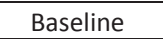 & 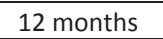 & ?]-??]列? \\
\hline \multicolumn{4}{|l|}{ 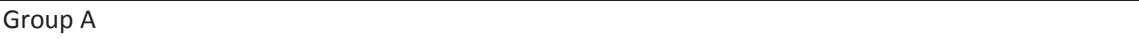 } \\
\hline 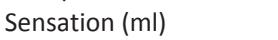 & 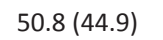 & 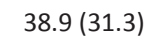 & ?]纬? \\
\hline 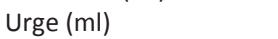 & 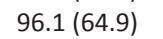 & 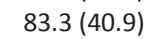 & ?]承? \\
\hline 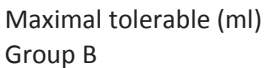 & [?]目四? ? ? & 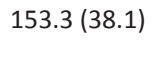 & ?]政? \\
\hline 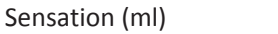 & 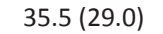 & 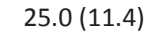 & ?]纬? \\
\hline 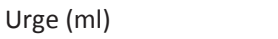 & 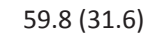 & 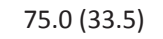 & ?]䌿? \\
\hline 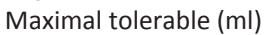 & 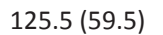 & 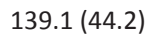 & ?]踝? \\
\hline
\end{tabular}

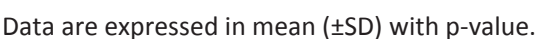

\section{目围回? 目}

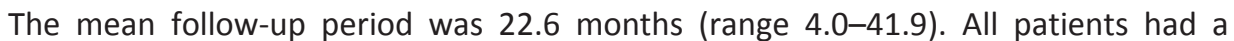

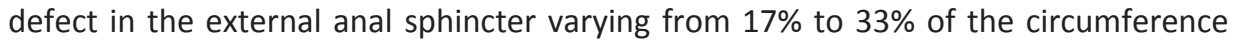

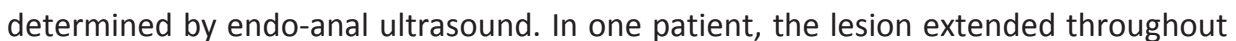

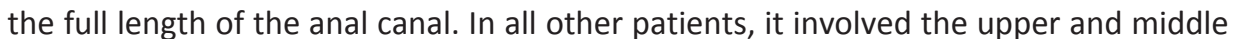

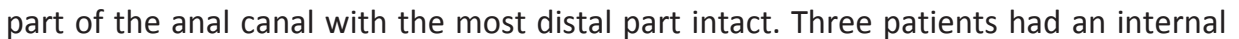

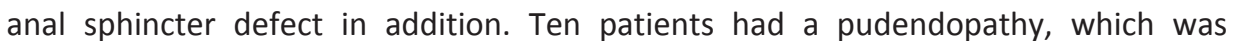

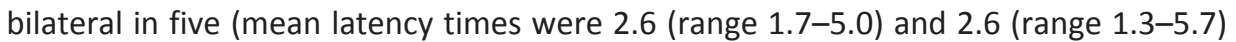

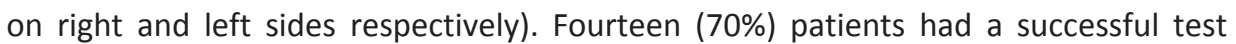

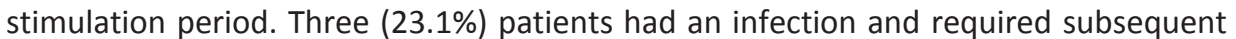

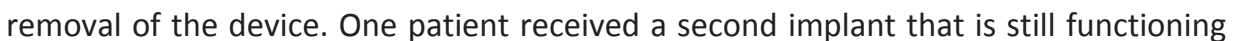

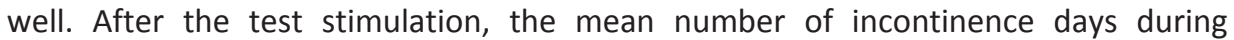

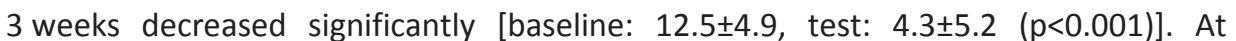




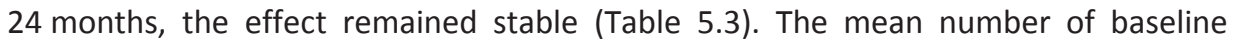

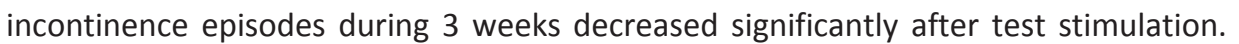

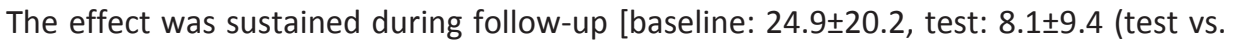

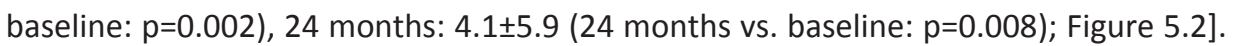

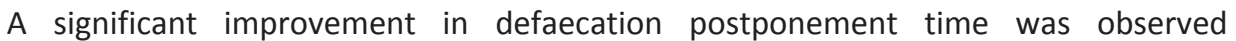

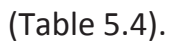

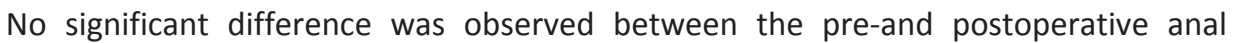

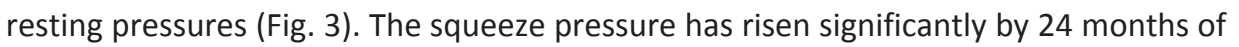

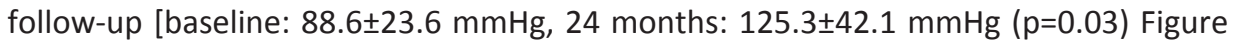

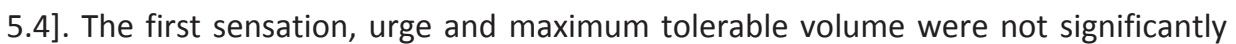

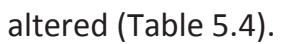

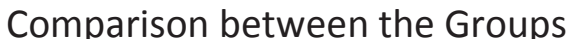

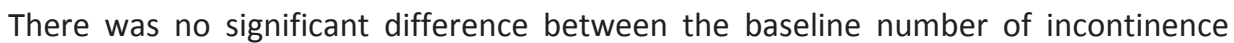

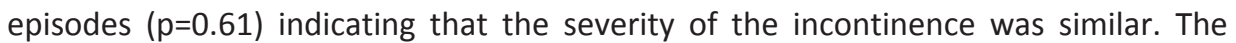

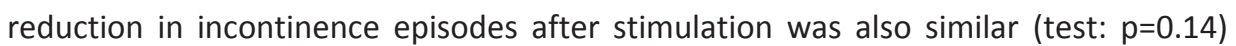

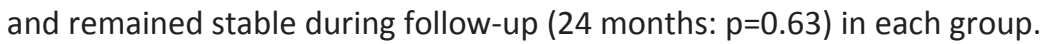

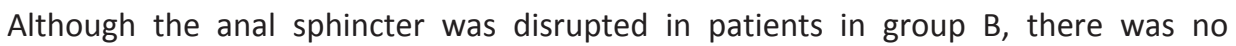

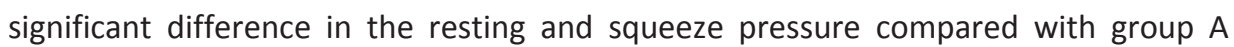

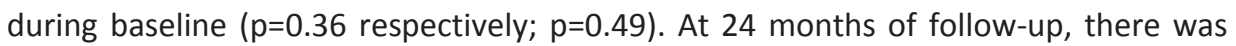

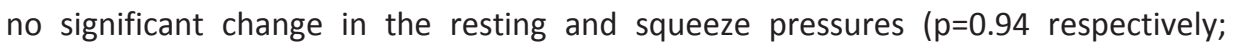

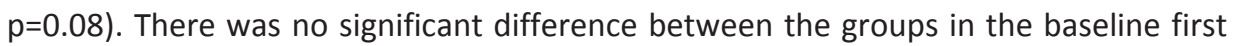

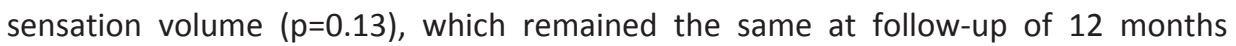

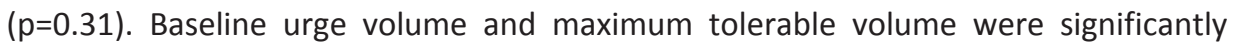

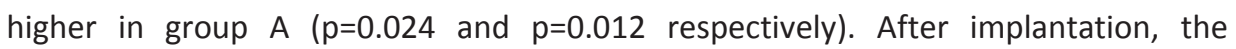

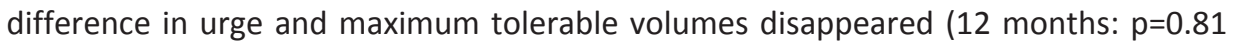

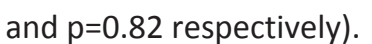

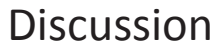

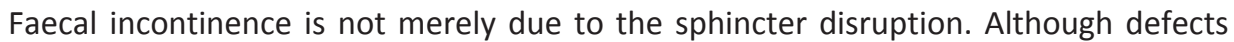

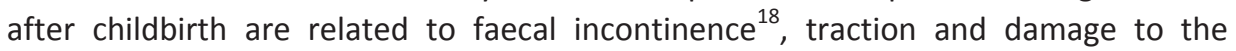

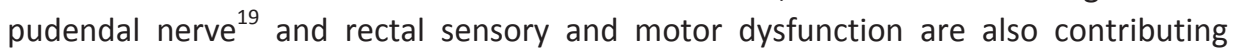

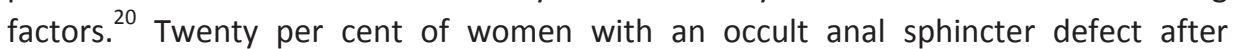

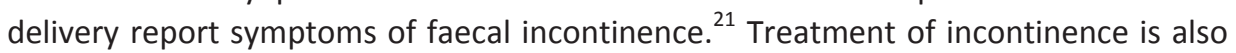

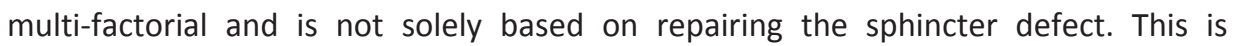

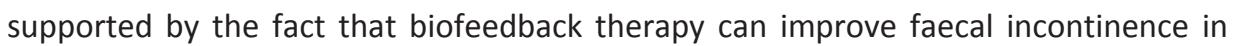

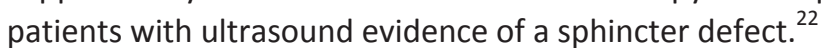

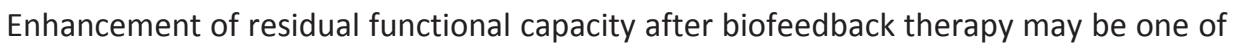

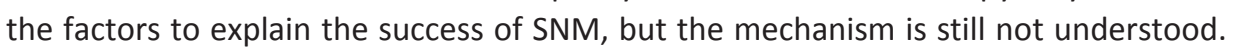




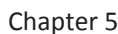

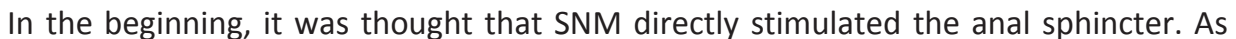

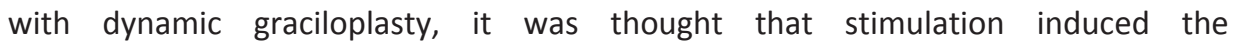

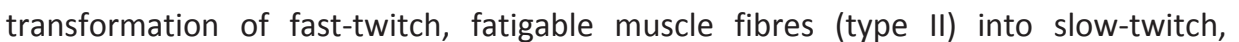

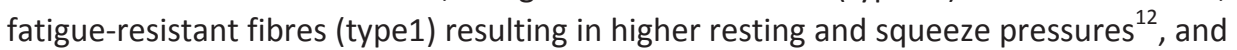

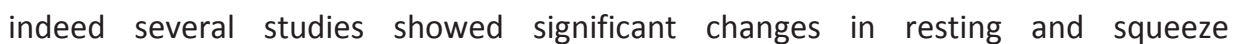

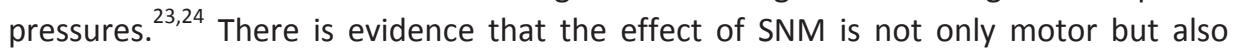

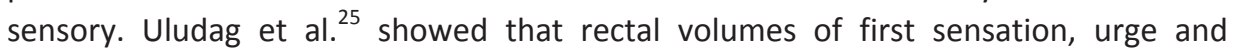

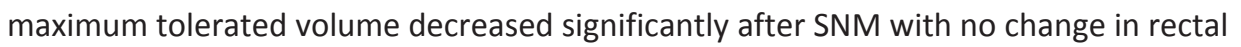

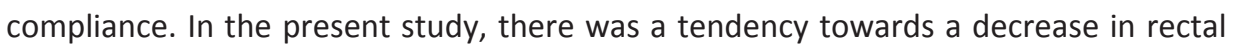

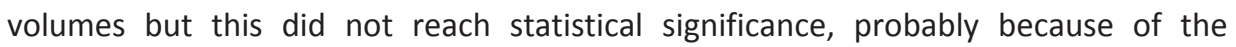

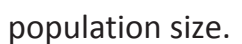

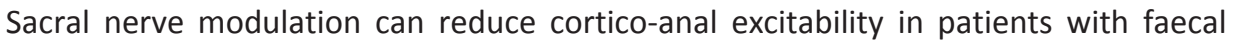

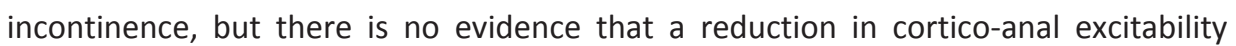

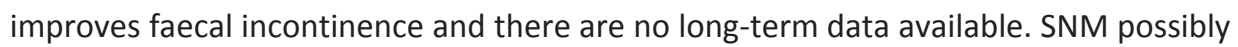

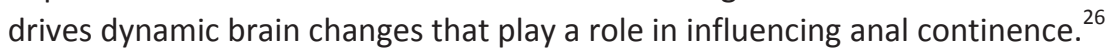

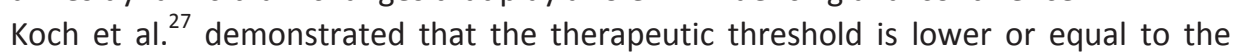

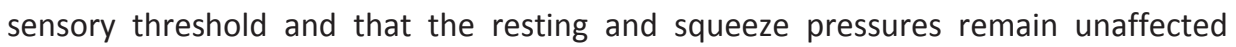

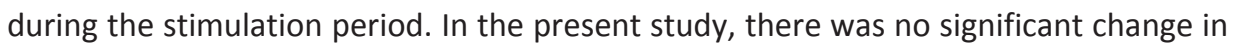

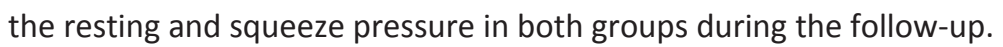

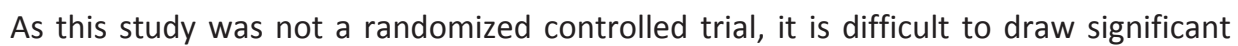

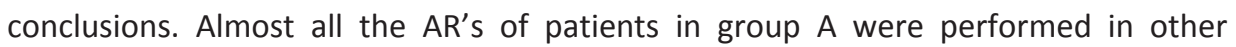

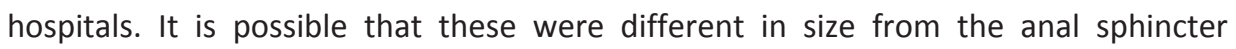

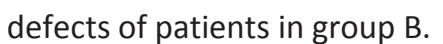

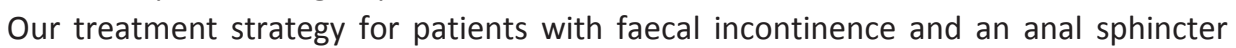

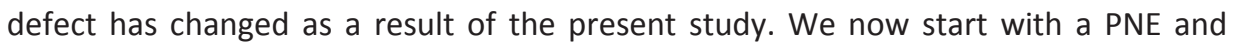

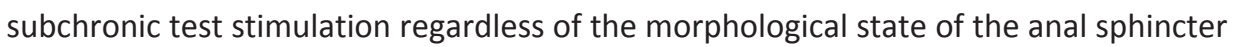

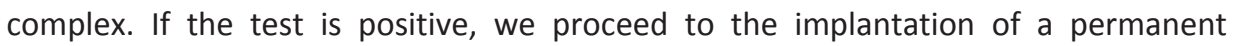

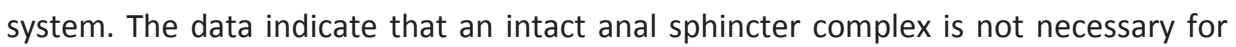

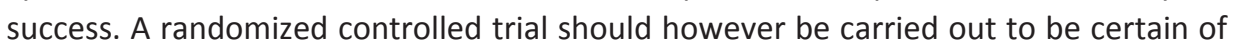

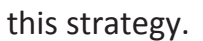

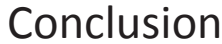

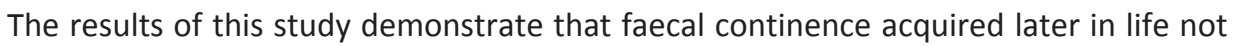

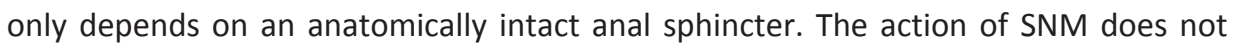

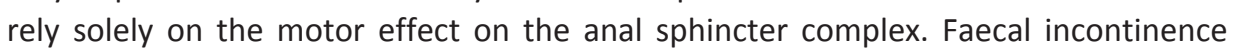

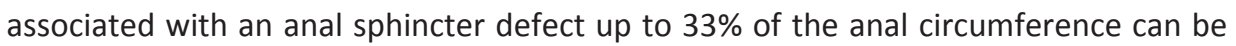

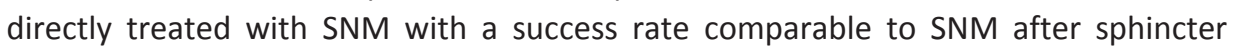

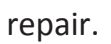




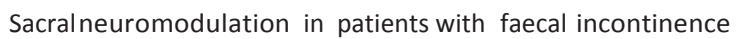

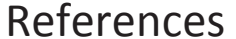

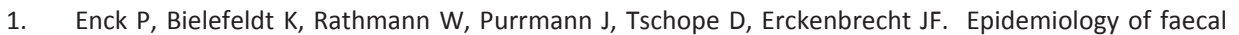

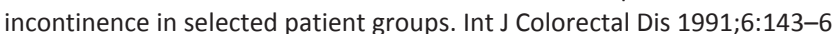

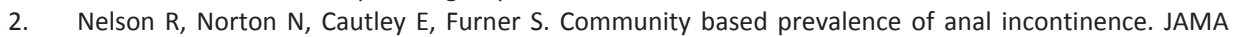

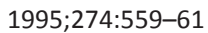

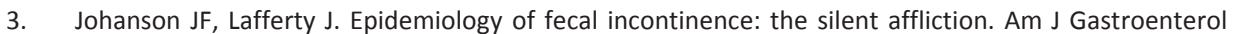

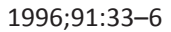

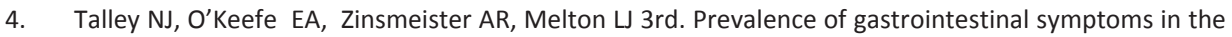

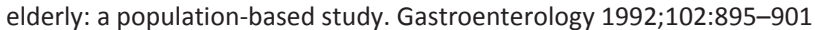

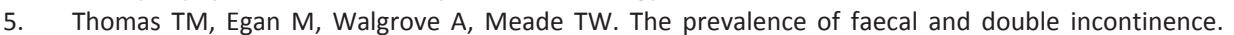

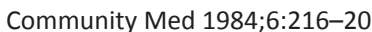

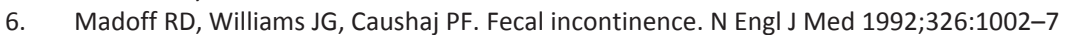

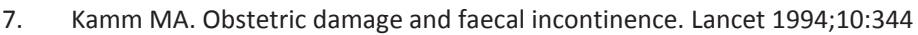

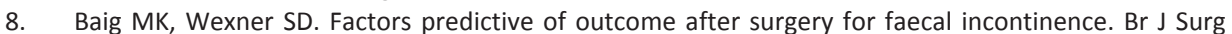

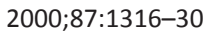

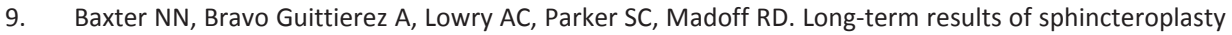

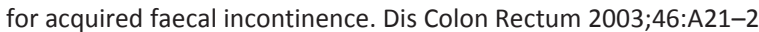

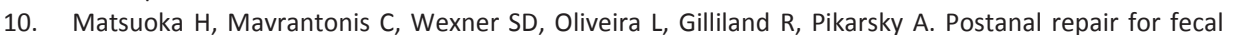

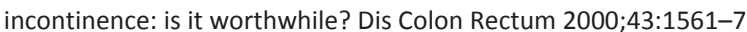

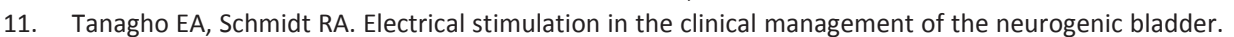

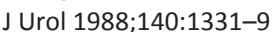

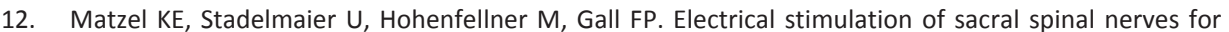

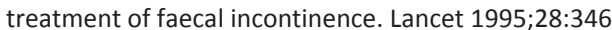

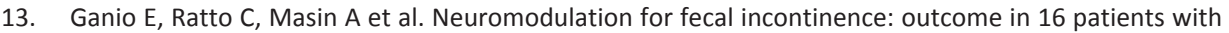

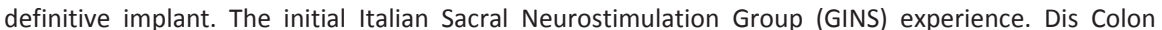

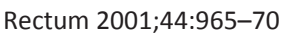

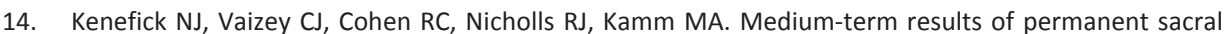

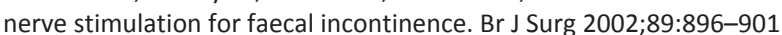

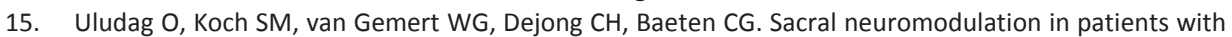

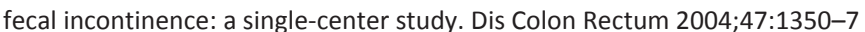

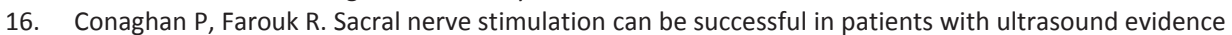

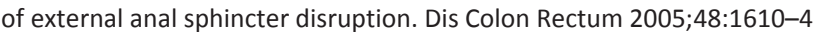

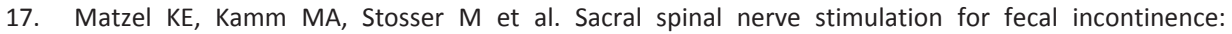

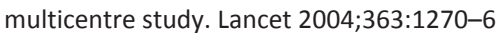

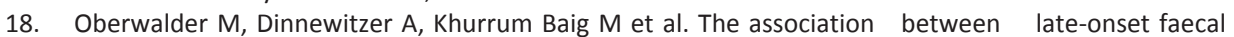

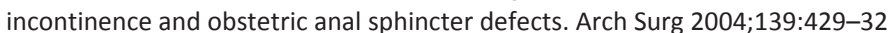

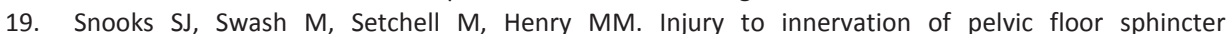

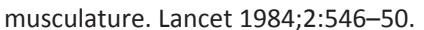

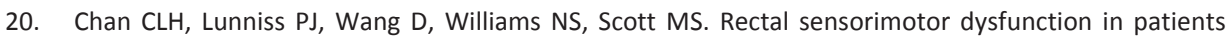

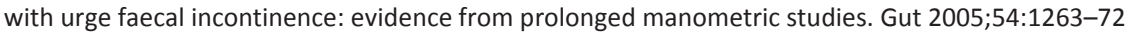

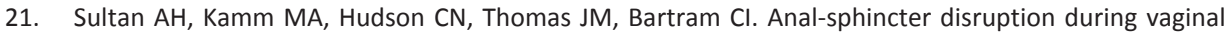

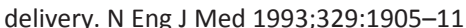

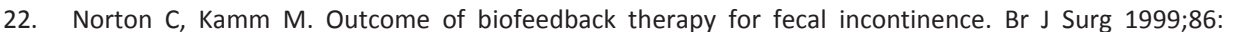

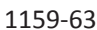

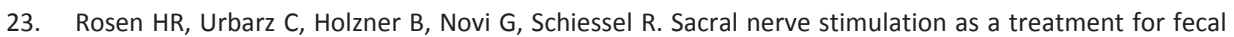

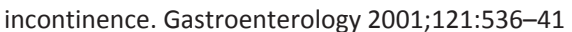

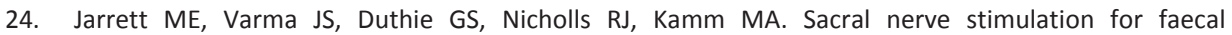

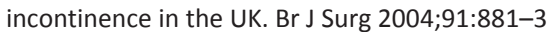

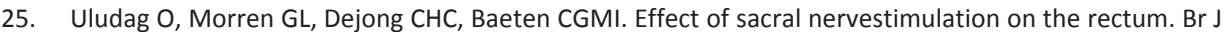

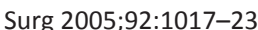

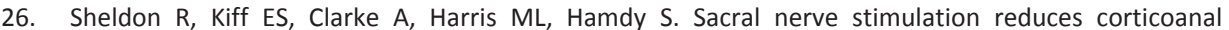

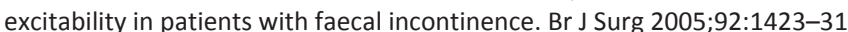




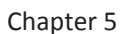

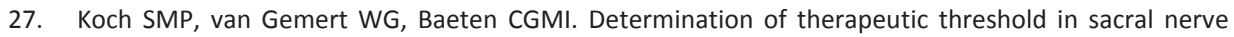

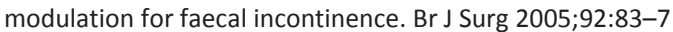




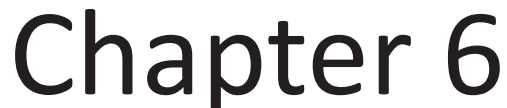

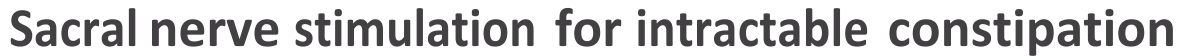

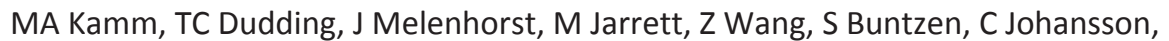

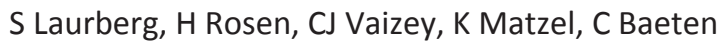

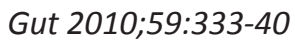




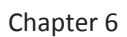

\section{?]?]?]?][?]?]}

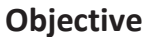

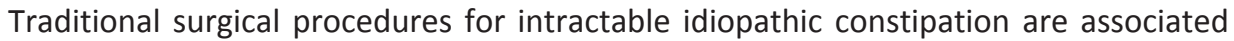

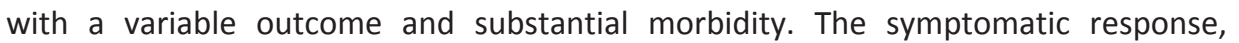

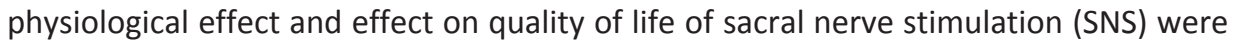

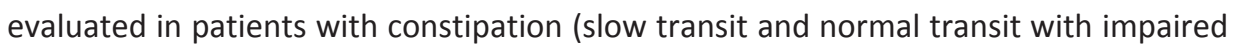

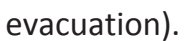

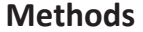

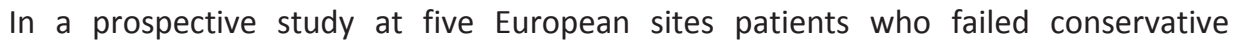

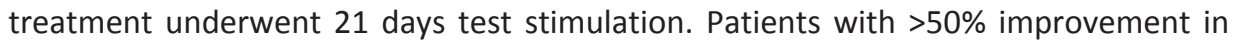

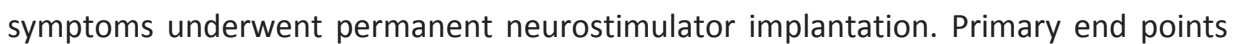

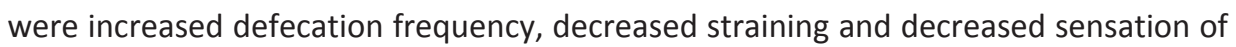

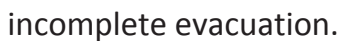

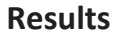

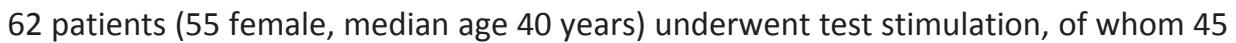

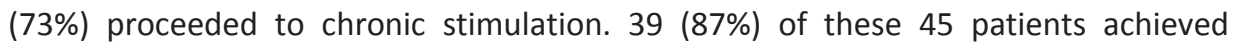

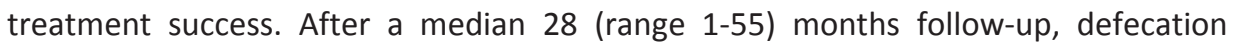

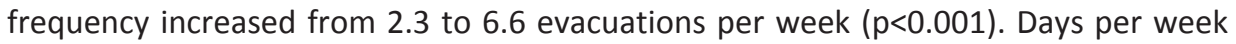

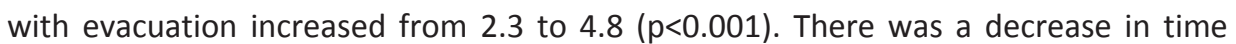

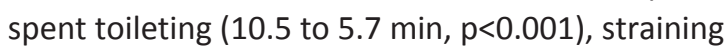

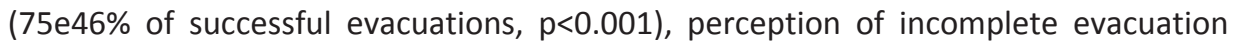

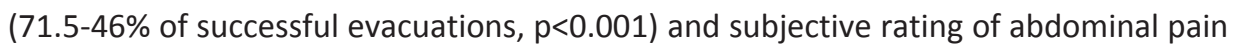

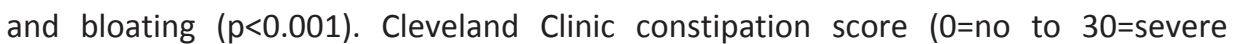

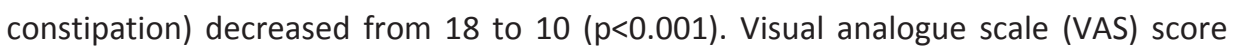

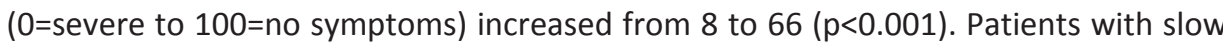

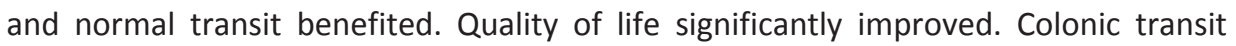

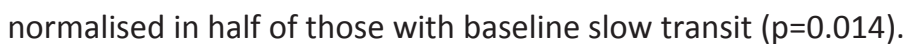

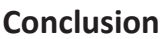

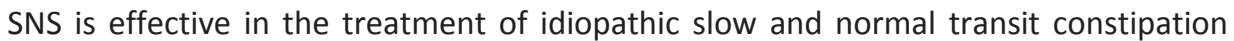

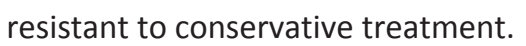




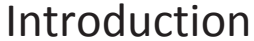

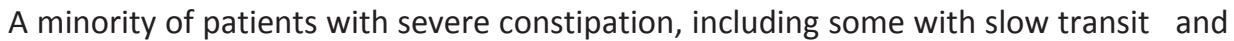

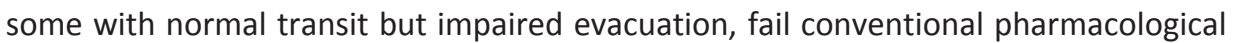

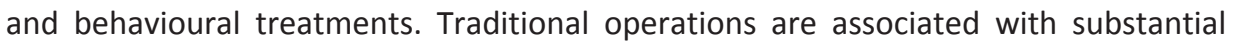

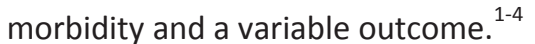

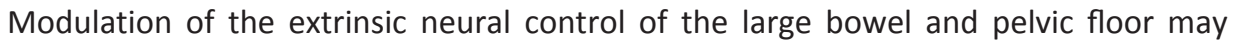

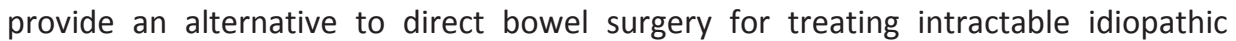

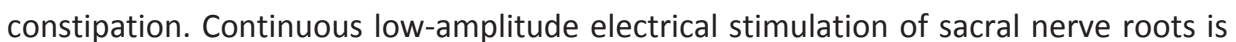

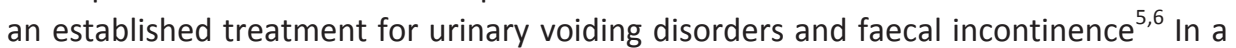

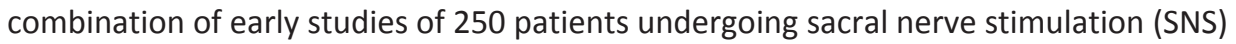

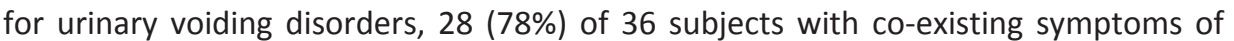

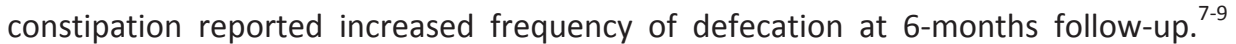

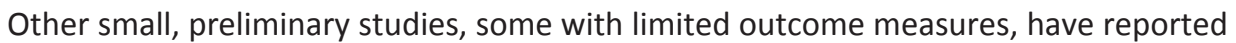

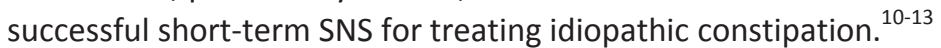

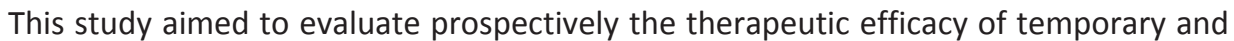

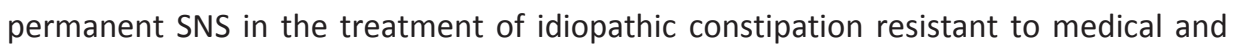

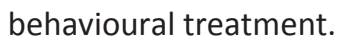

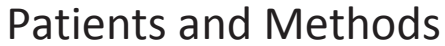

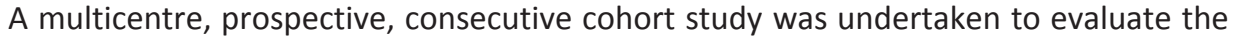

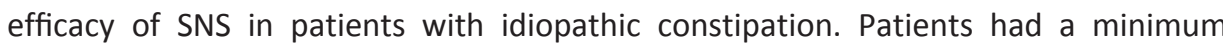

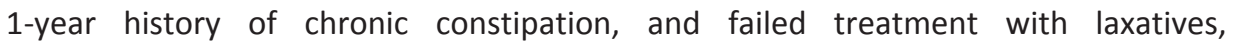

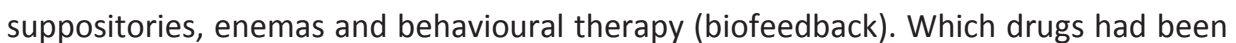

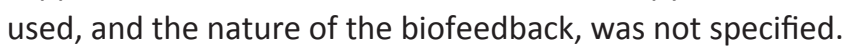

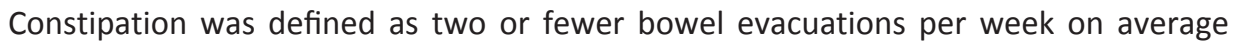

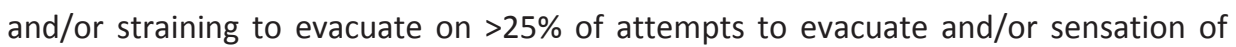

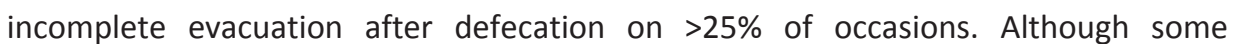

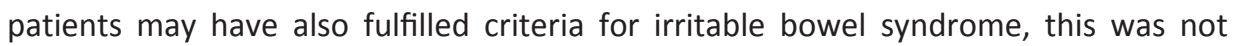

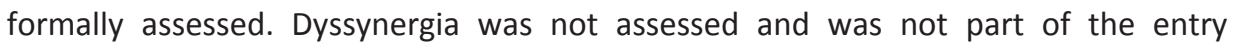

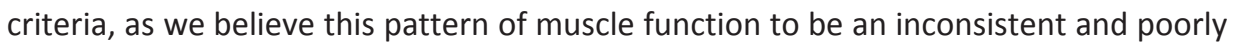

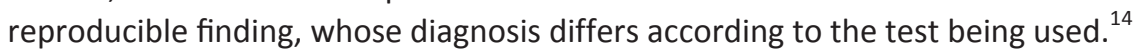

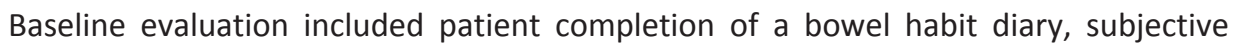

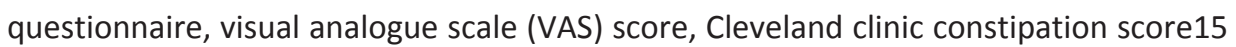

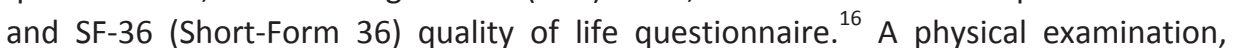

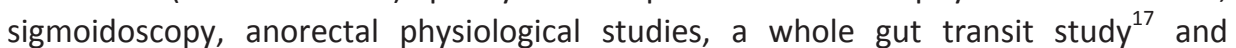

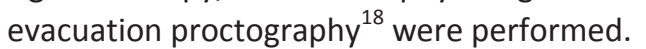

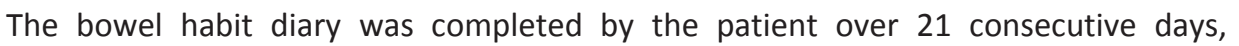

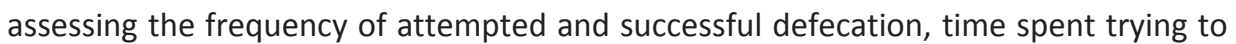

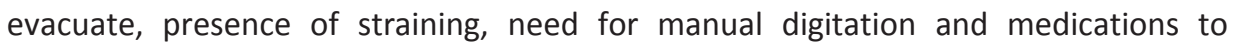




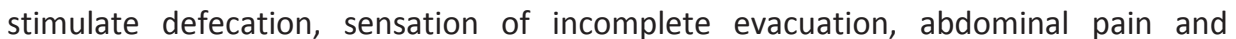

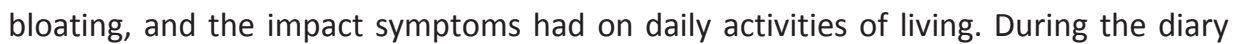

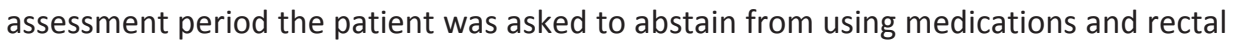
[5p

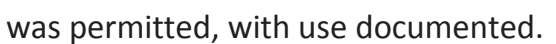

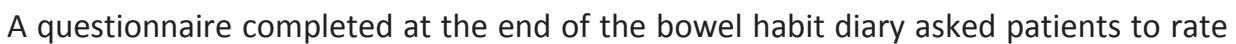

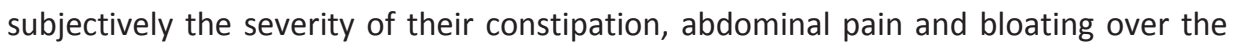

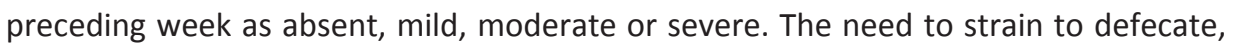

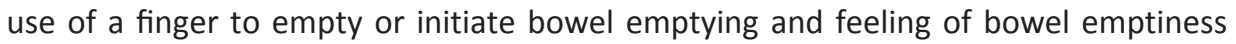

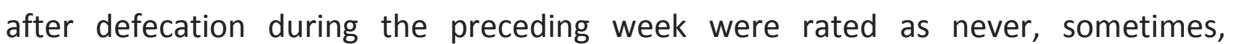

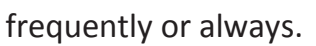

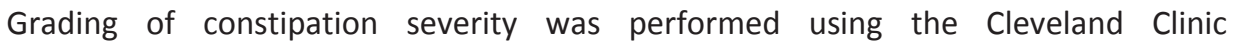

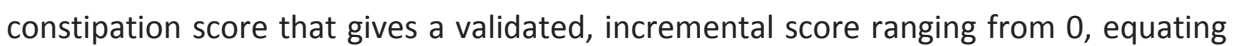

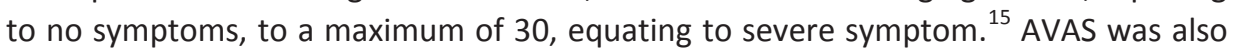

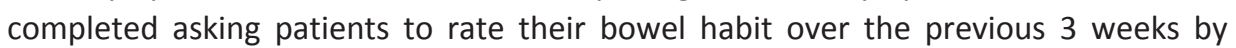

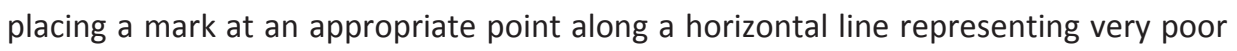

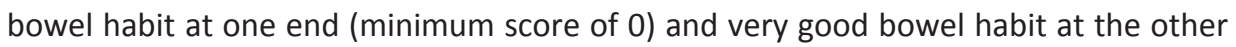

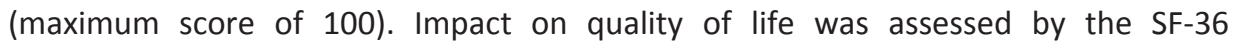

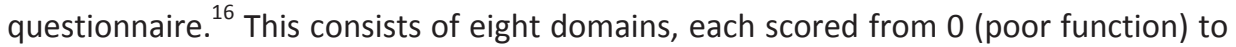

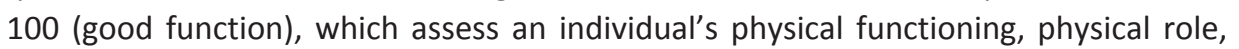

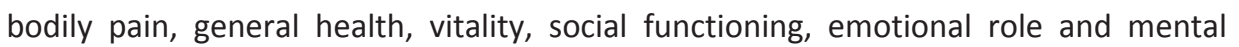

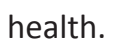

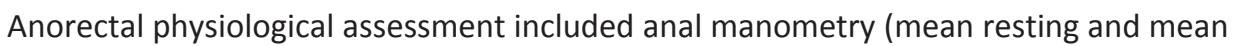

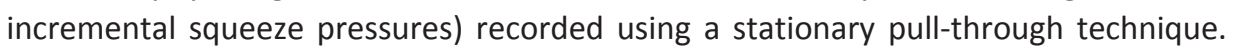

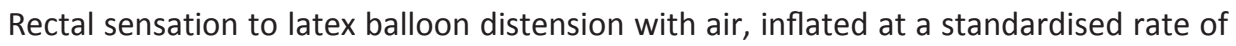

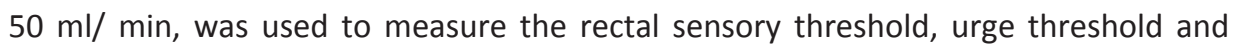

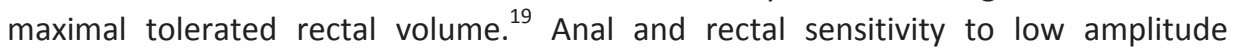

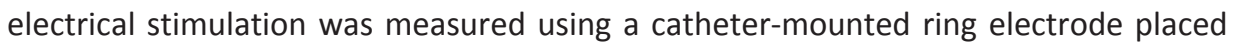

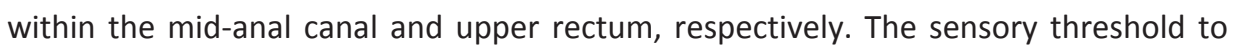

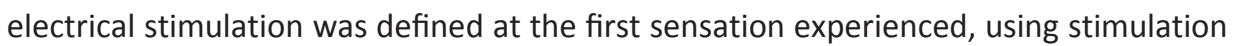

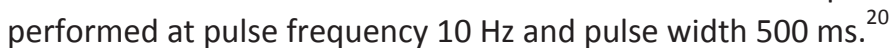

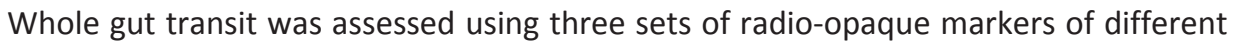

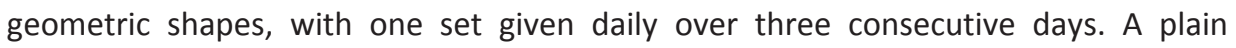

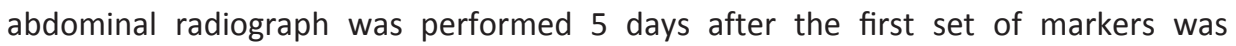

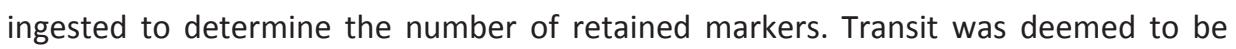

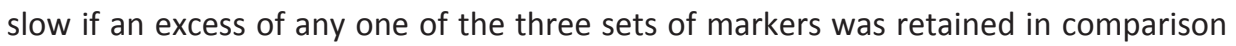

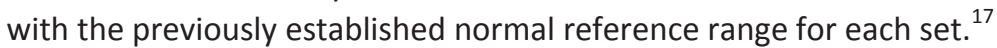

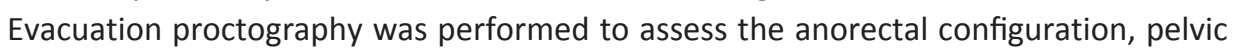

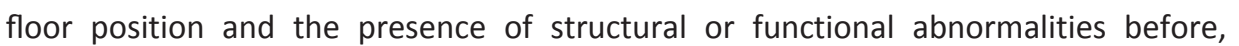

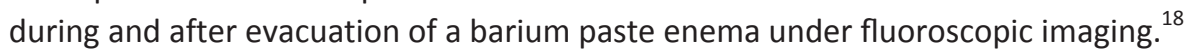




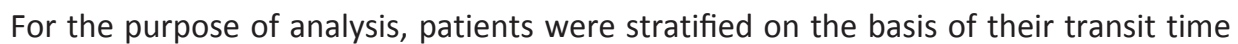

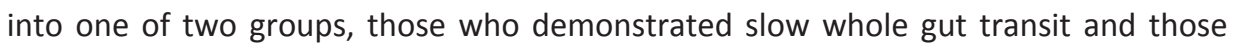

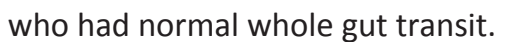

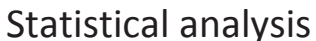

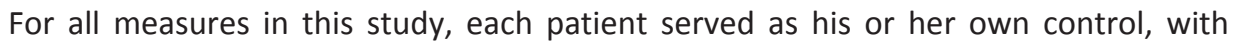

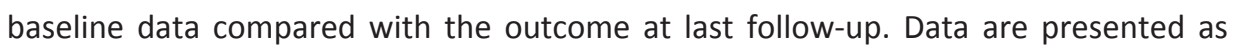

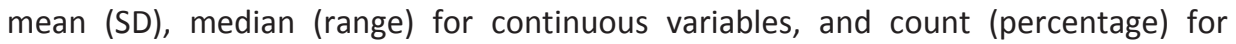

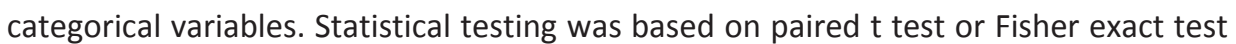

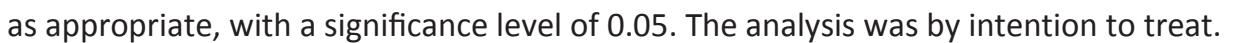

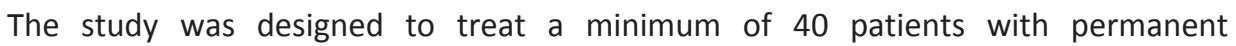

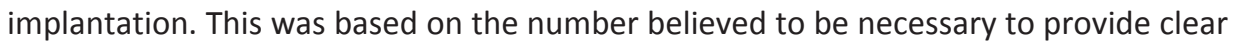

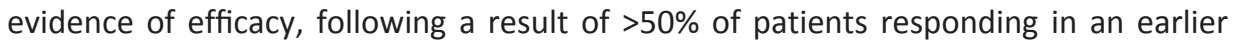

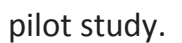

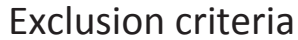

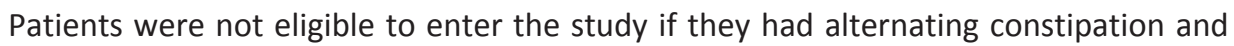

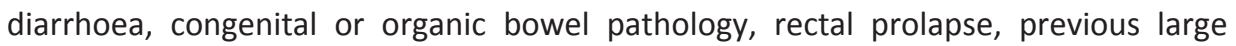

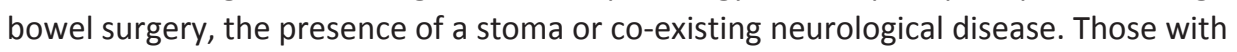

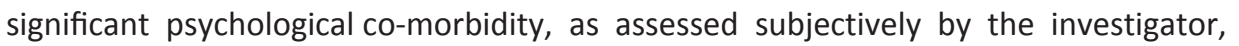

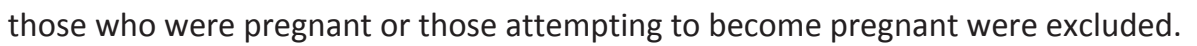

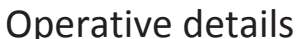

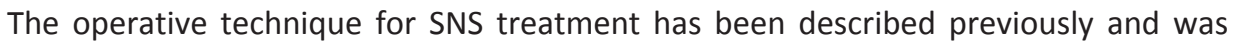

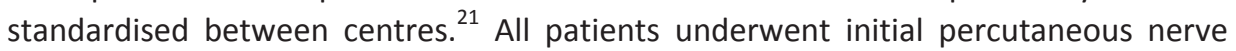

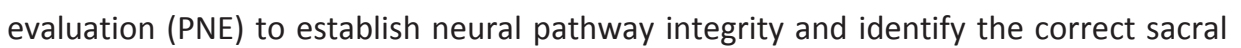

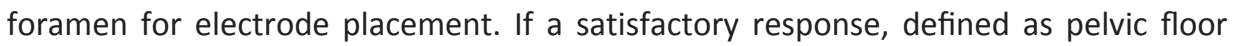

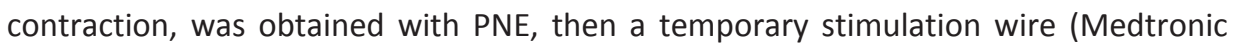

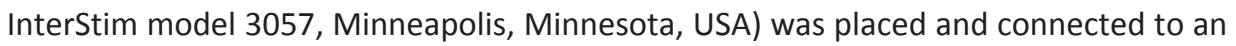

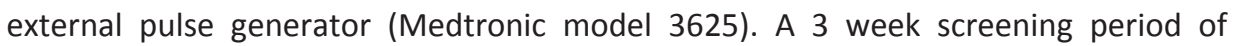

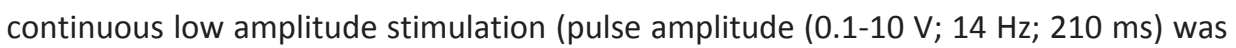

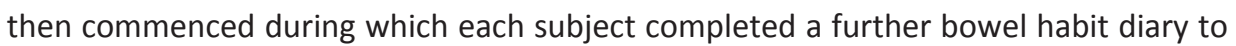

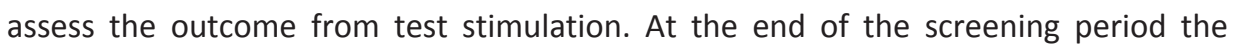

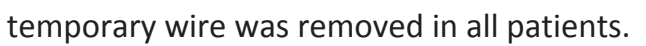

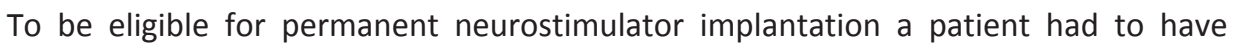

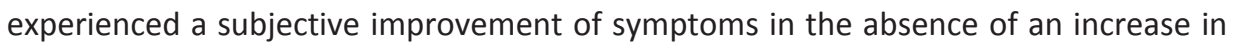

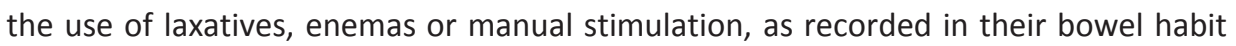

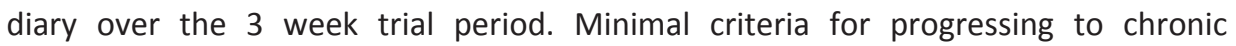

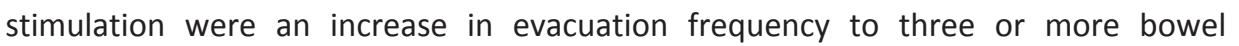




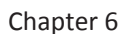

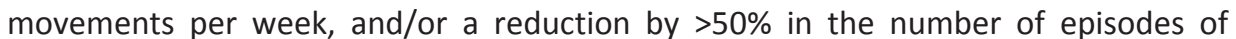

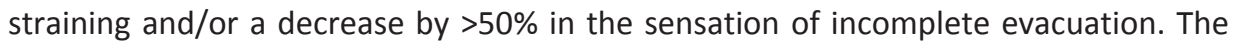

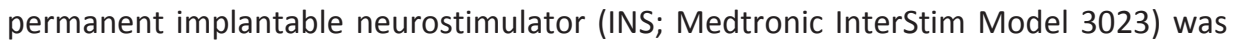

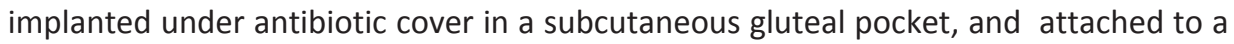

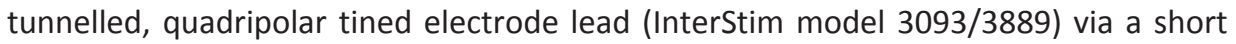

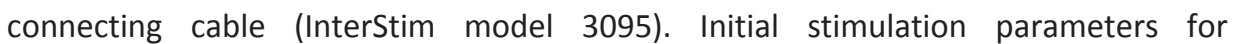

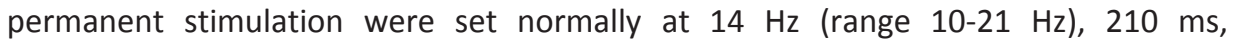

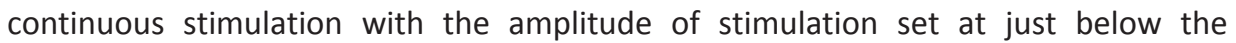

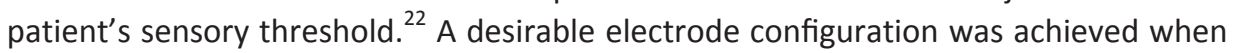

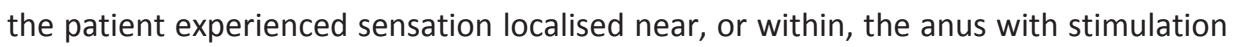

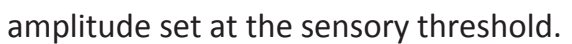

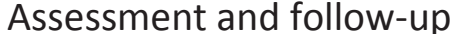

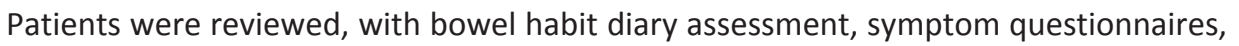

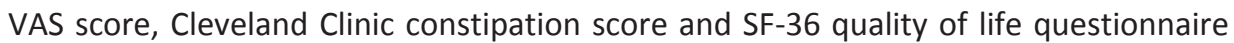

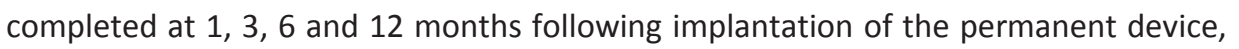

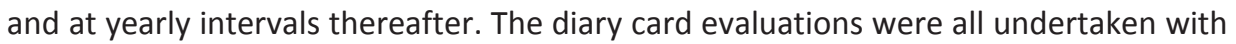

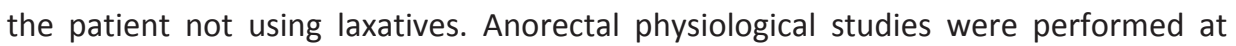

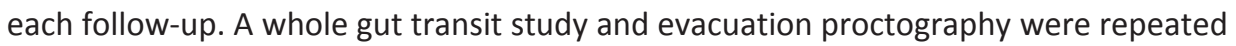

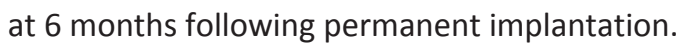

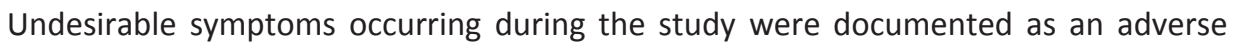

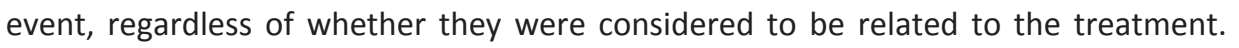

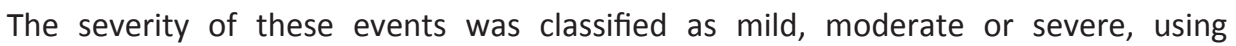

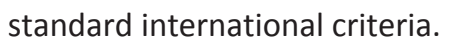

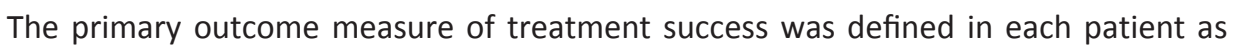

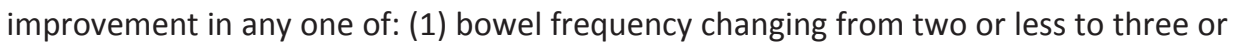

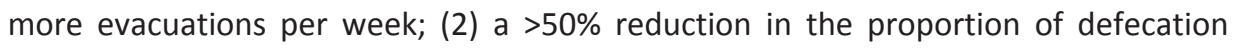

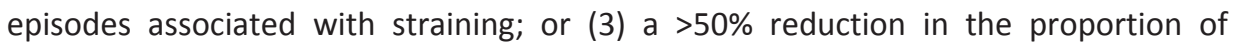

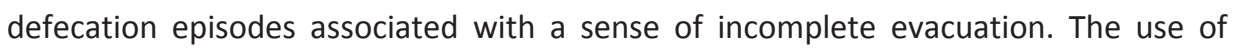

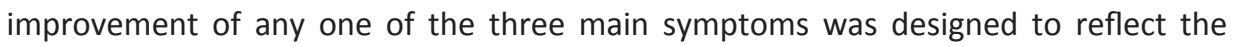

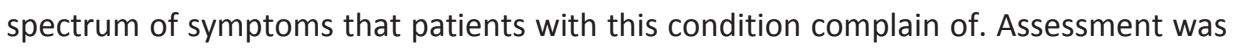

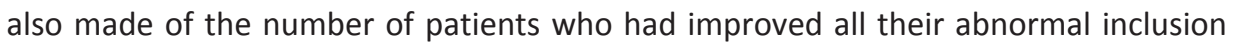

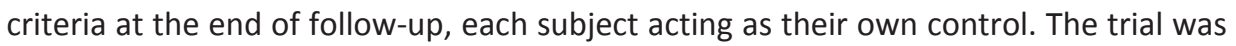

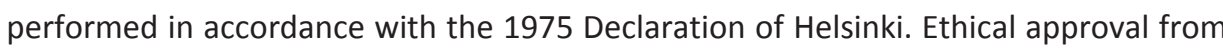

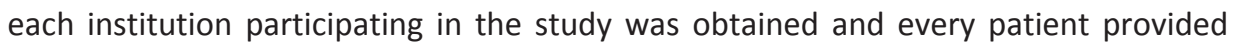

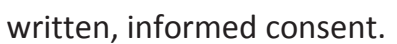




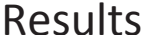

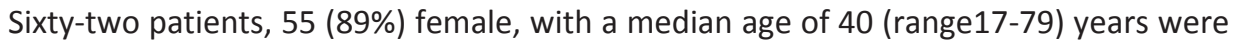

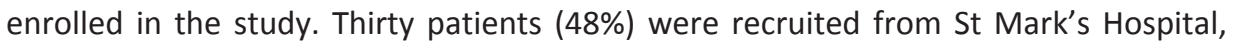

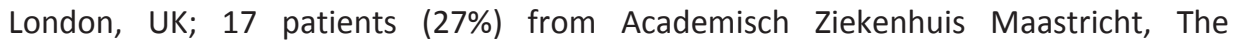

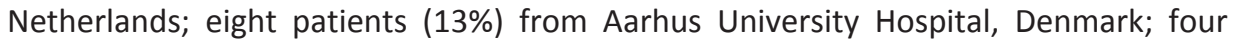

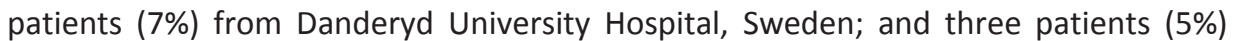

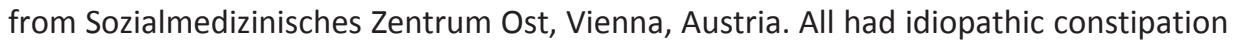

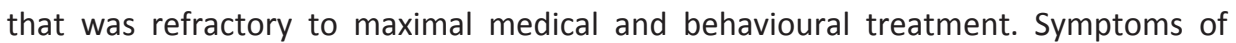

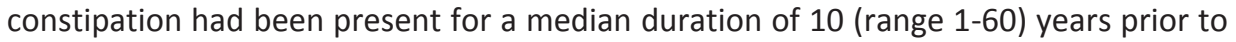

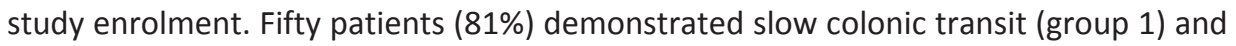

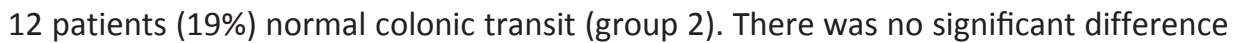

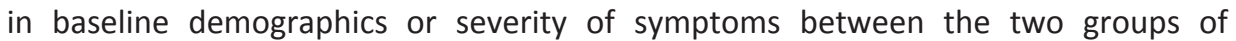

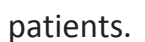

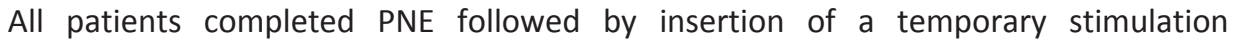

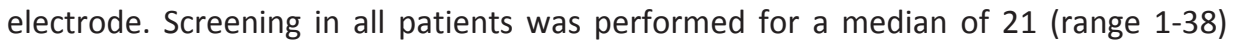

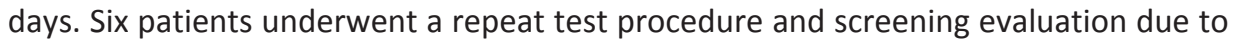

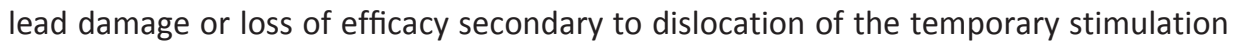

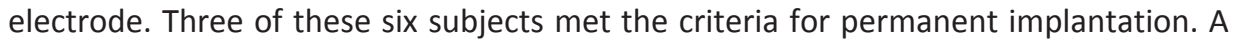

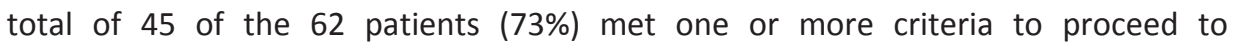

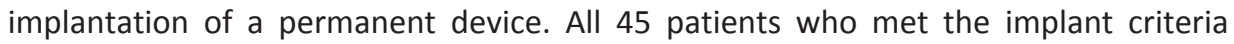

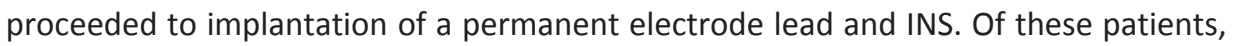

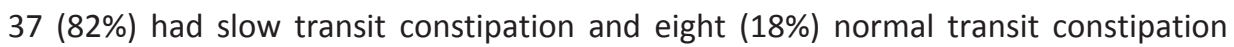

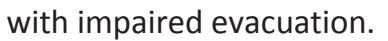

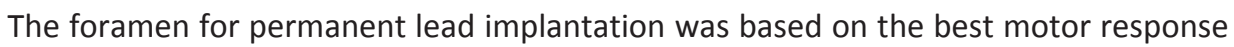

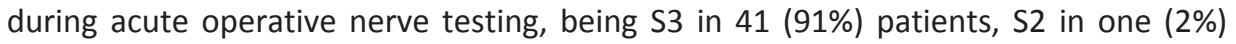

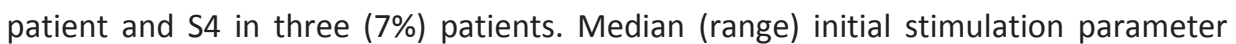

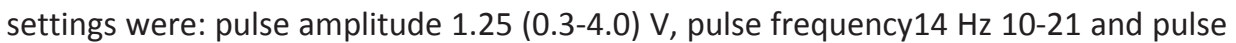

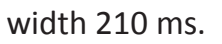

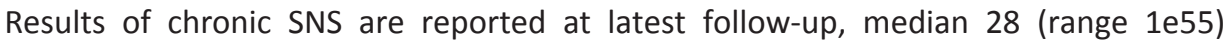

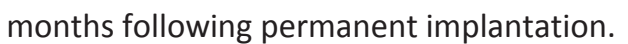

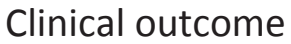

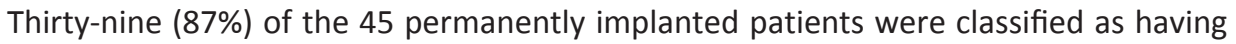

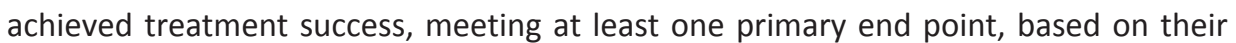

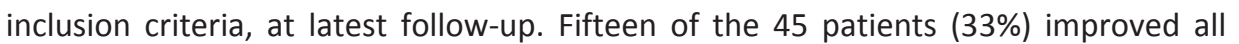

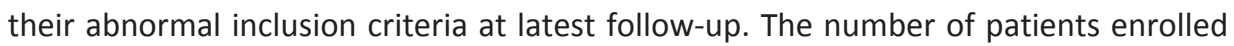

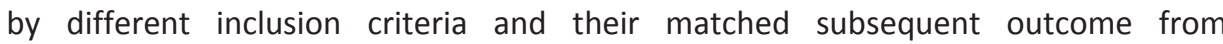

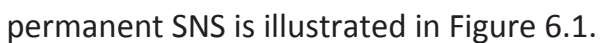




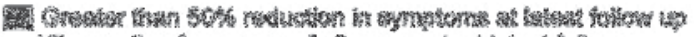

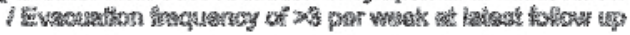

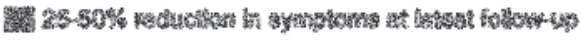

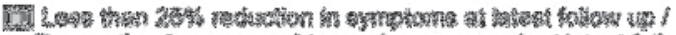

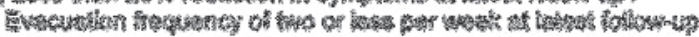

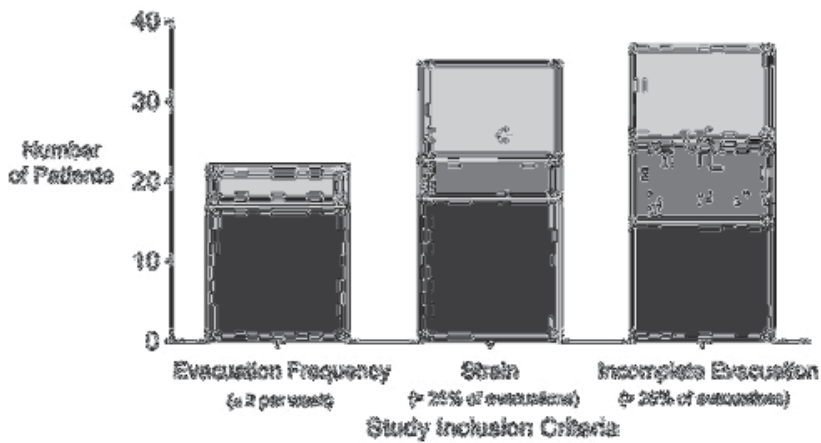

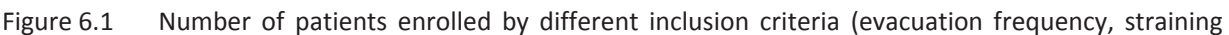

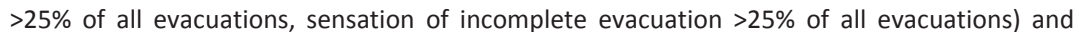

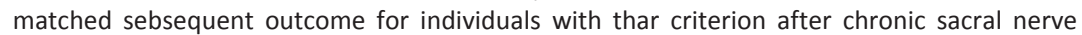

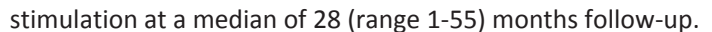

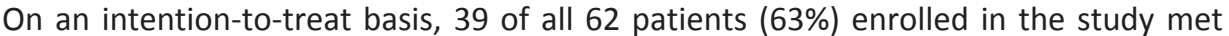

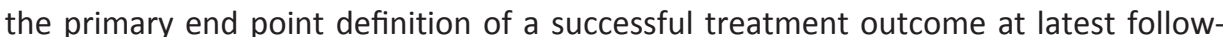
ㅇ?ㅇ?

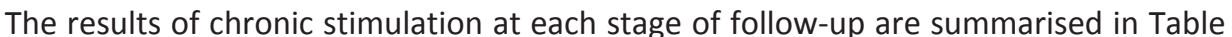
[?

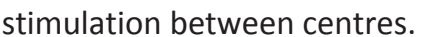

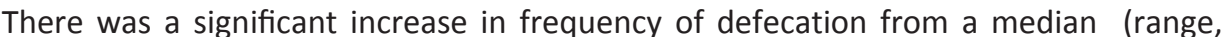

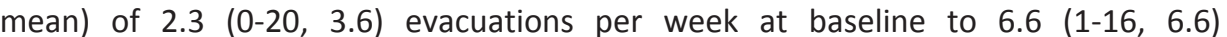

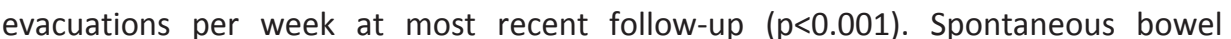

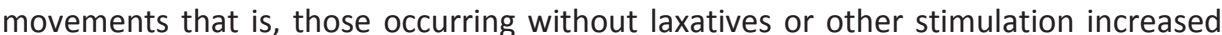

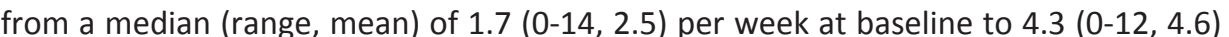

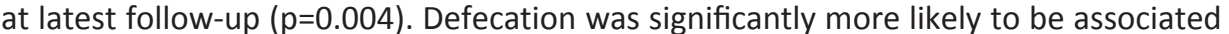

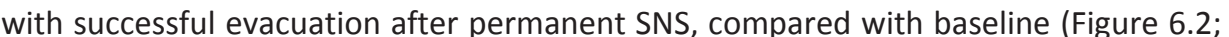

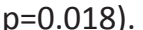




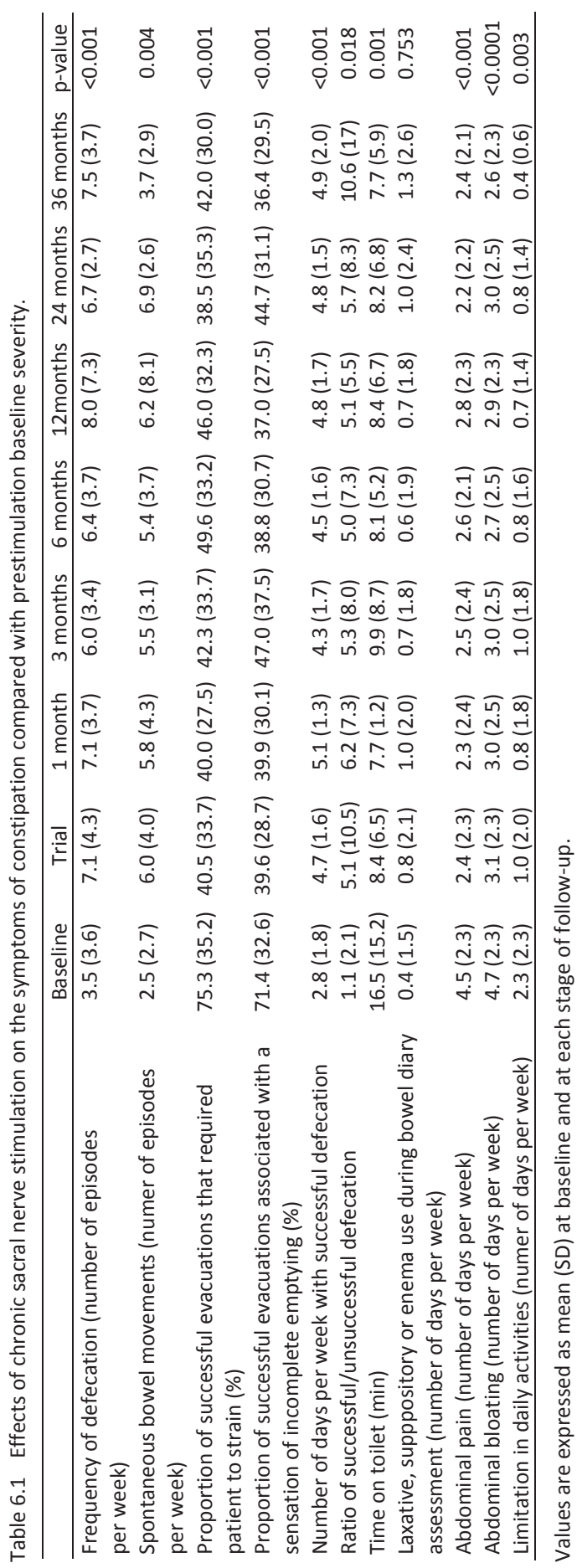




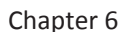

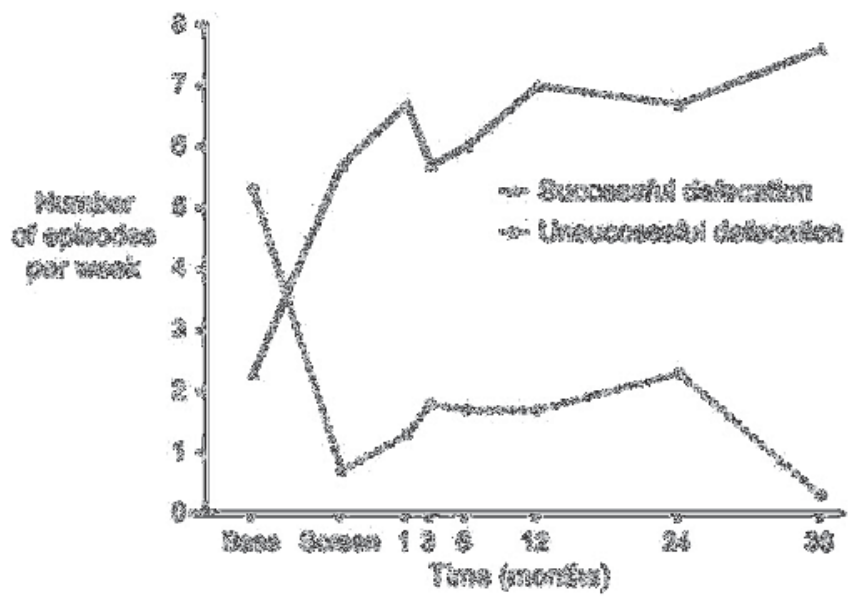

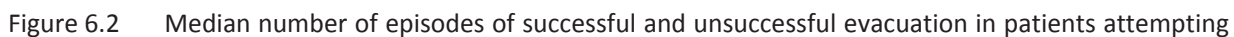

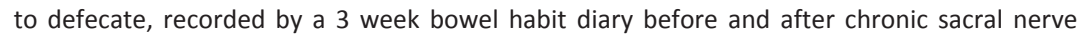

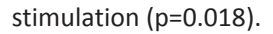

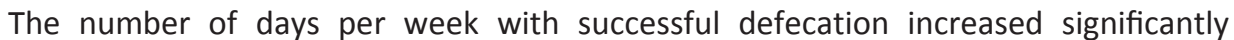

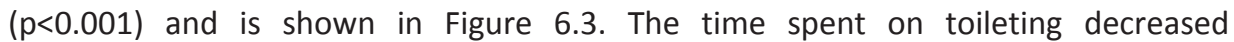

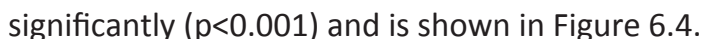

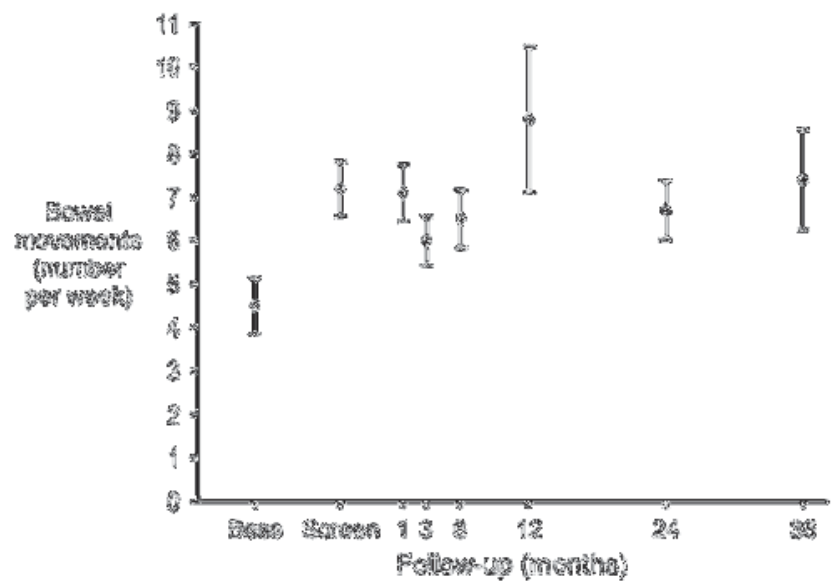

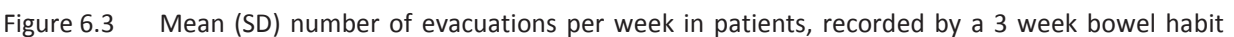

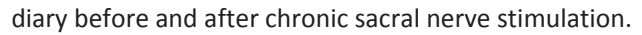




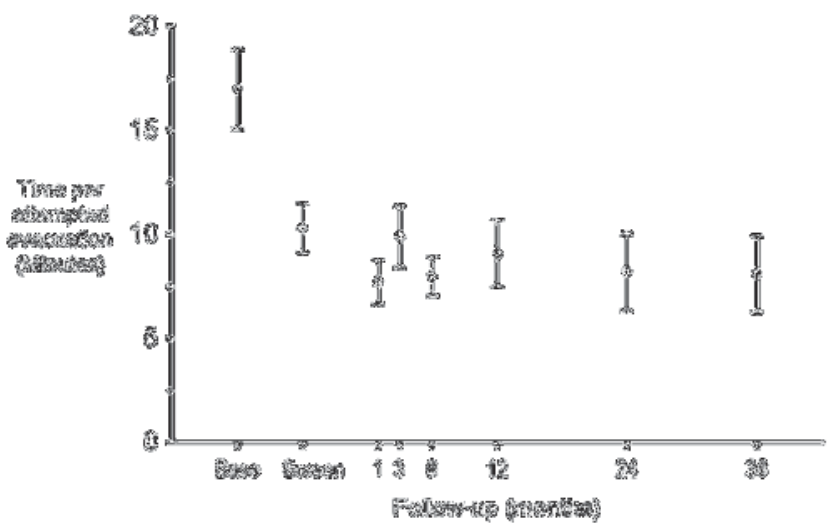

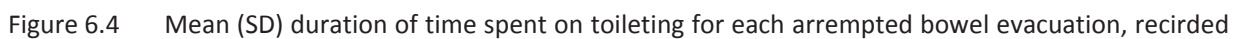

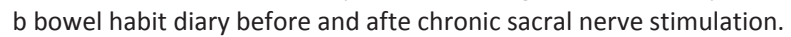

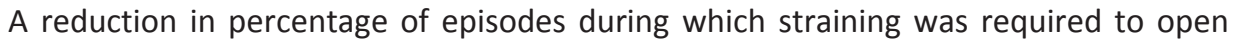

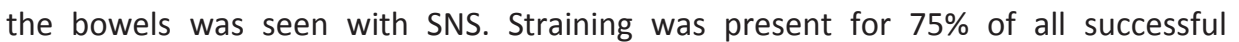

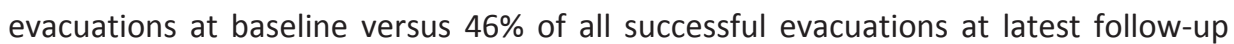

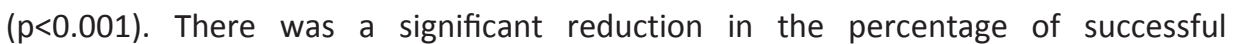

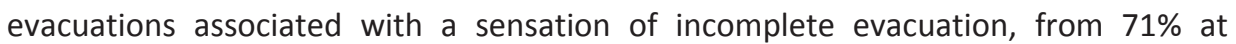

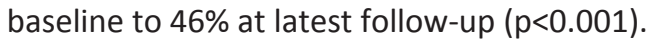

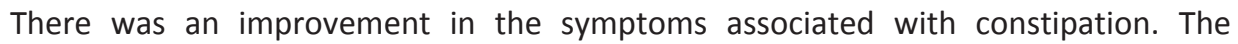

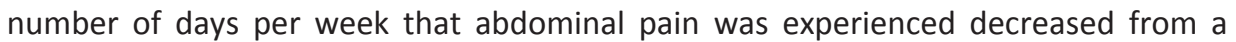

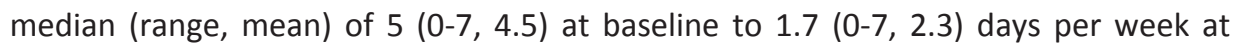

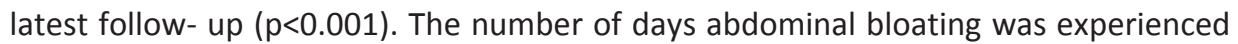

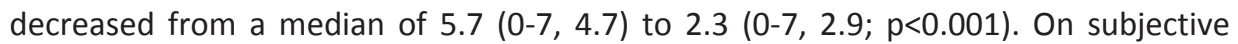

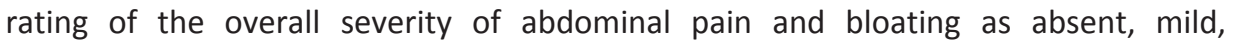

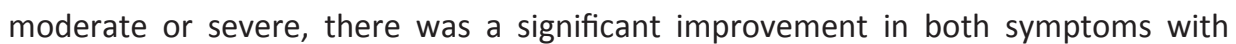

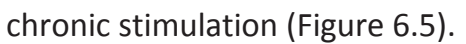

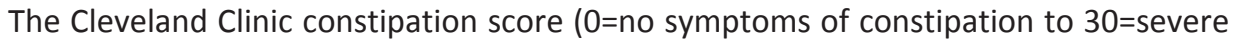

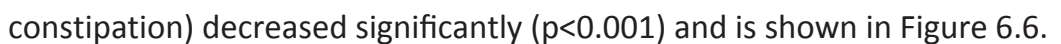



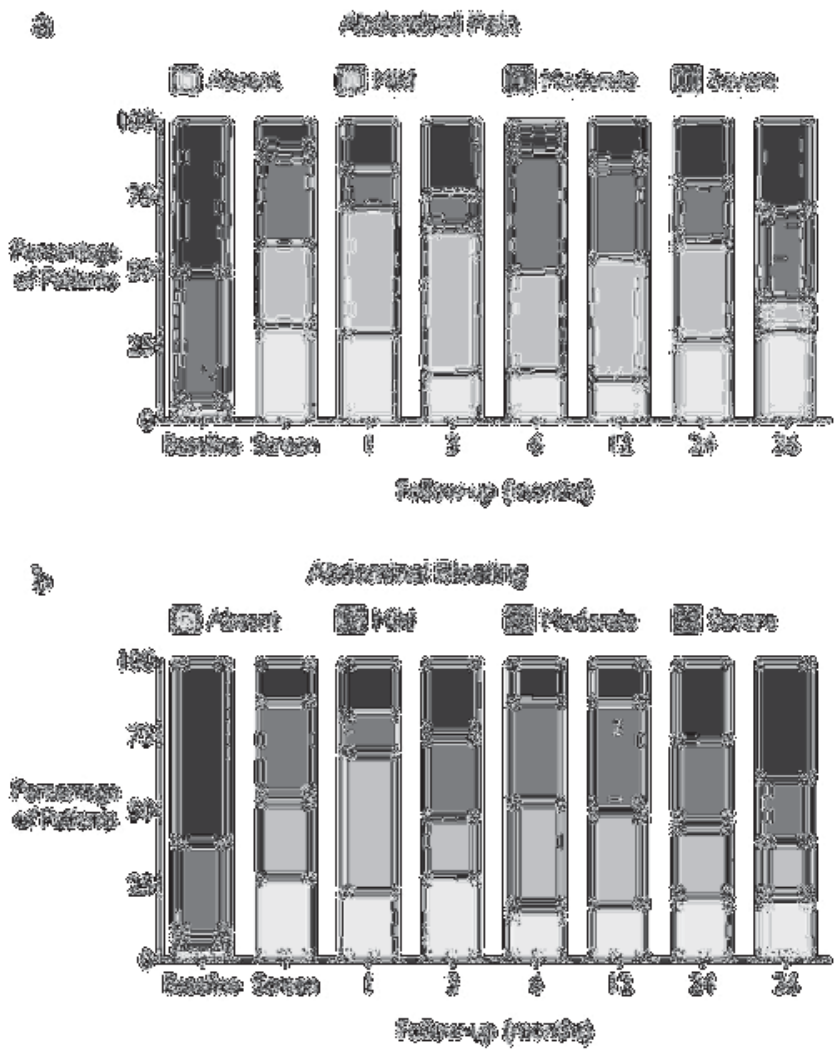

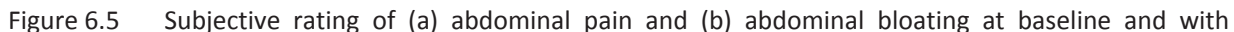

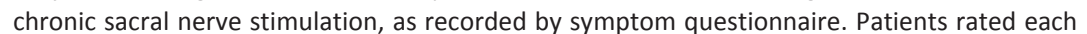

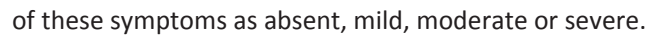

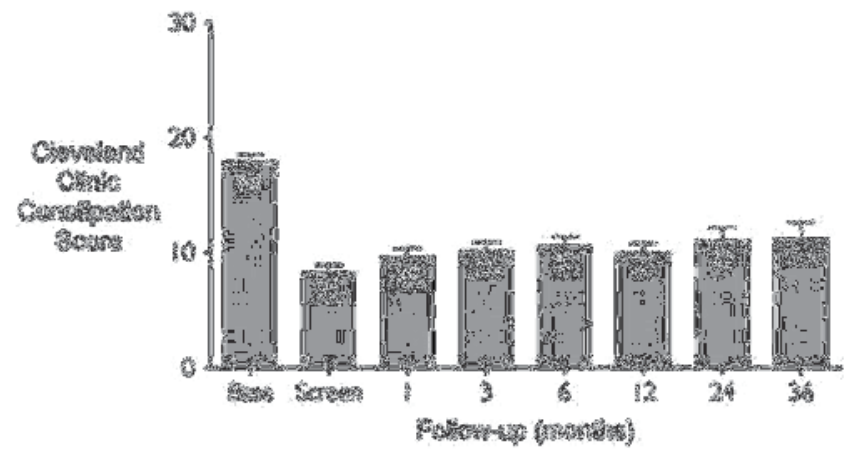

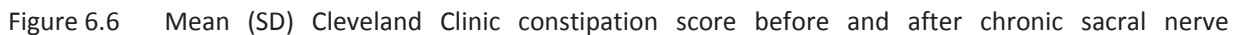

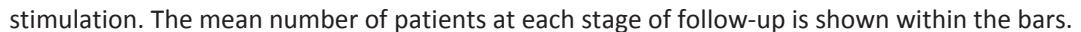




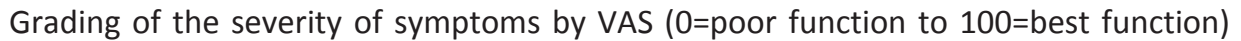

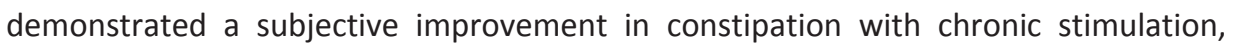

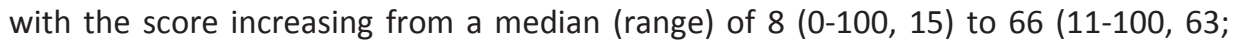

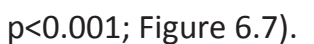

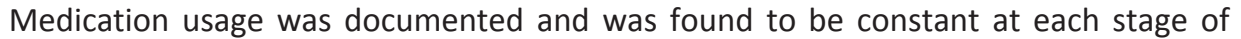

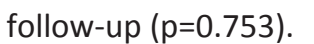

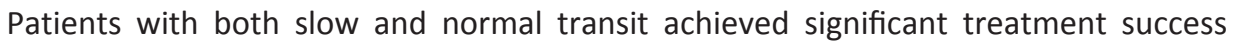

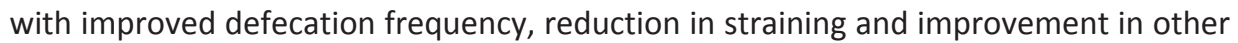

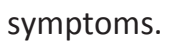

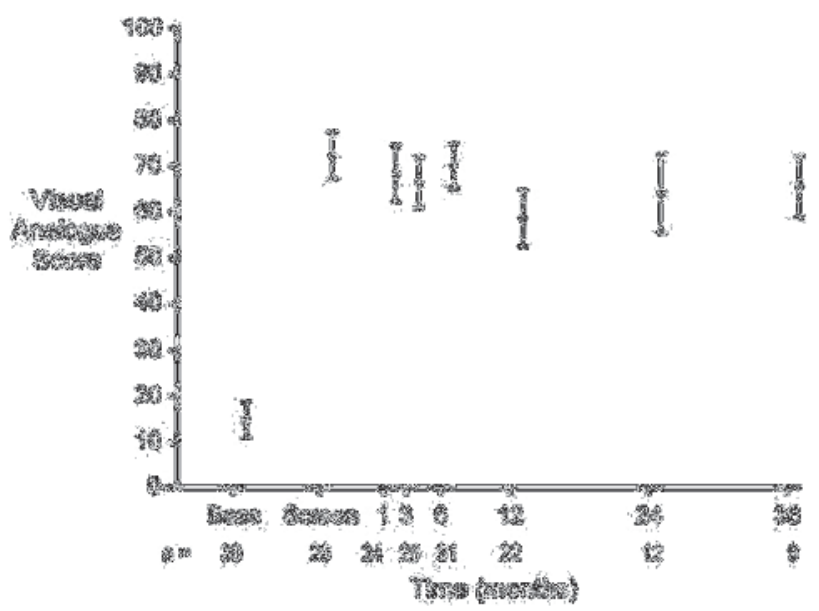

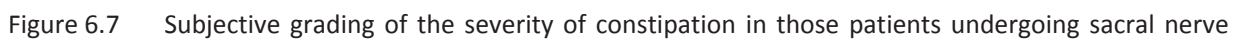

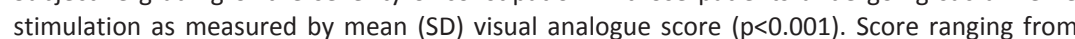

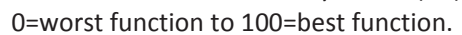

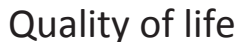

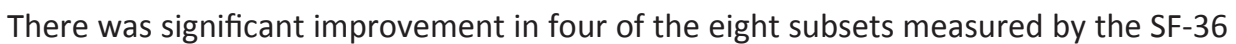

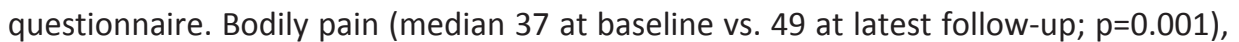

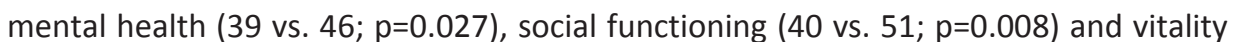

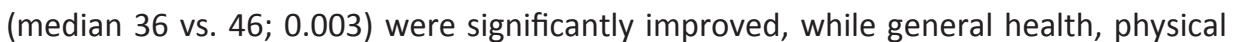

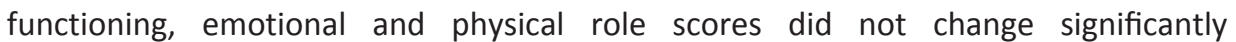

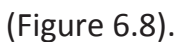




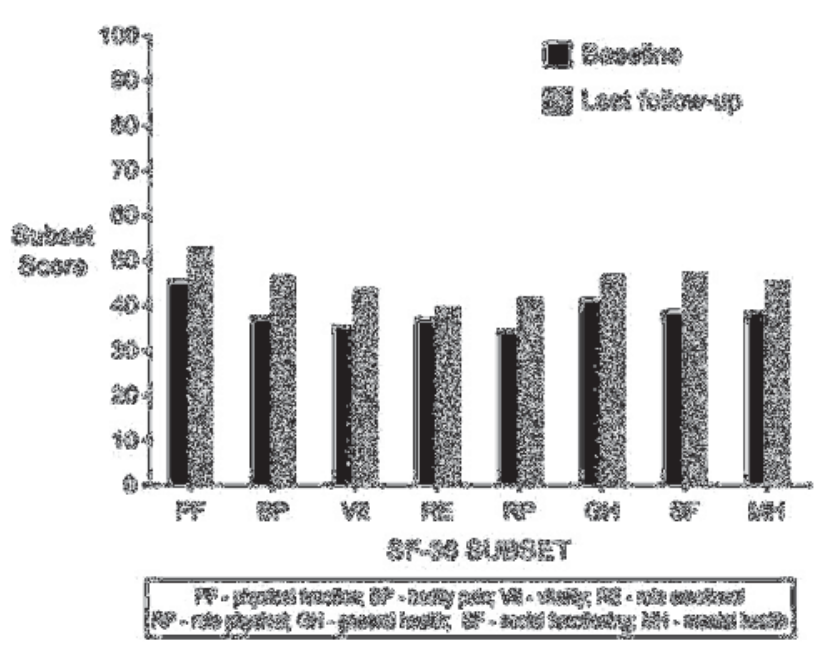

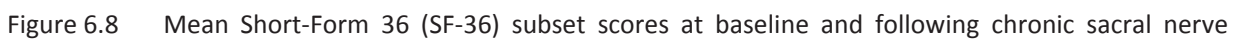

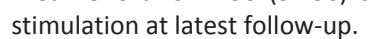

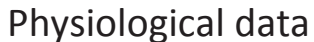

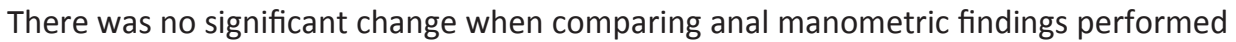

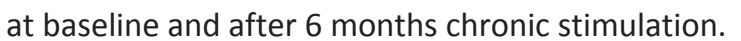

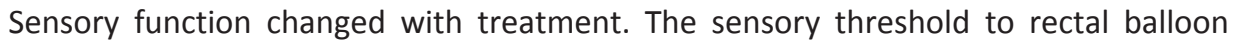

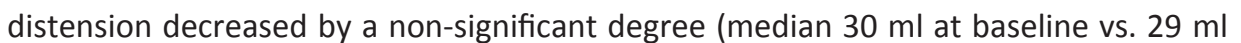

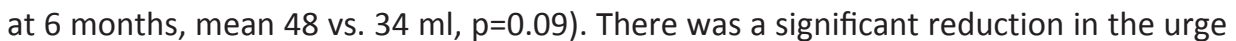

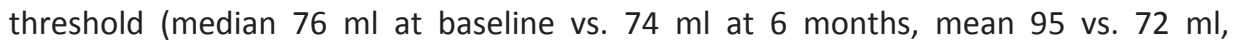

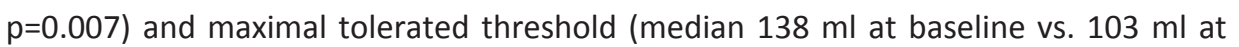

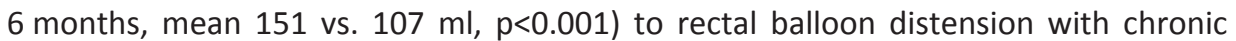

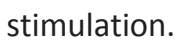

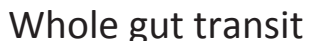

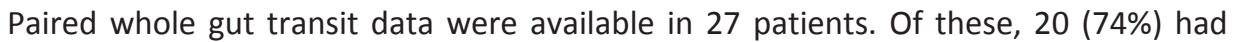

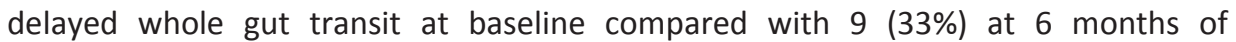

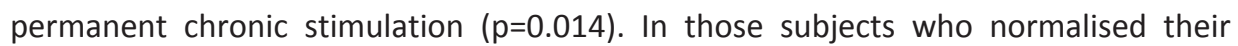

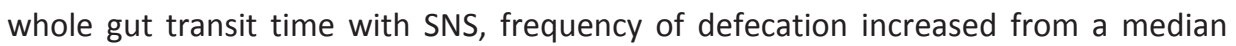

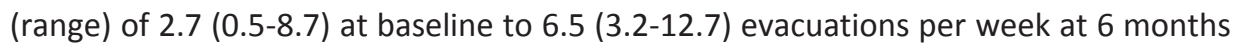

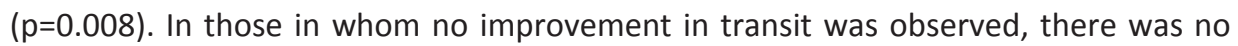

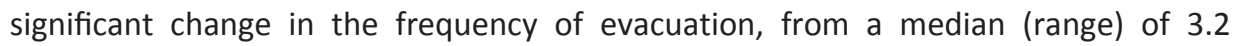

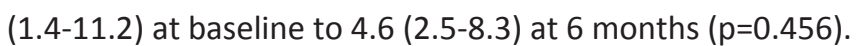




\section{[?]?]?]?]?[?]?}

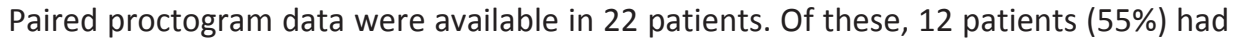

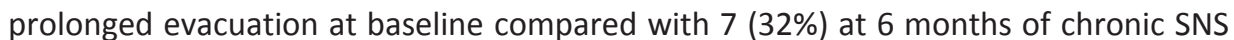

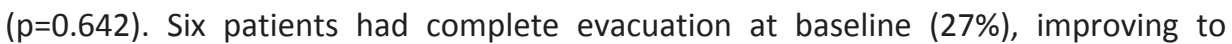

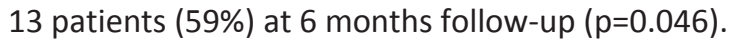

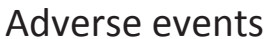

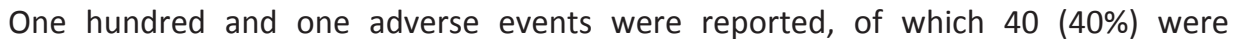

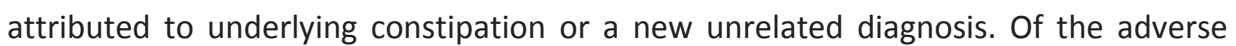

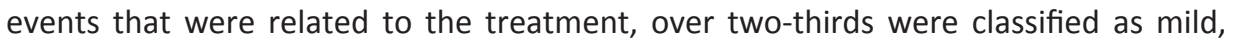

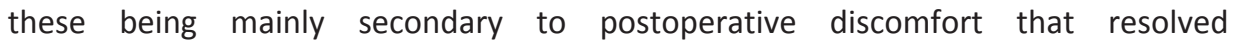

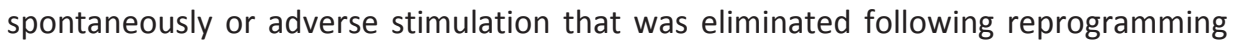

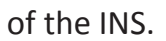

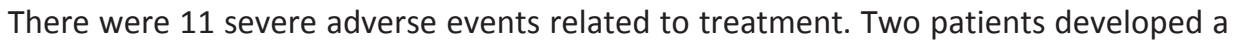

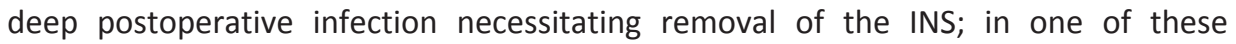

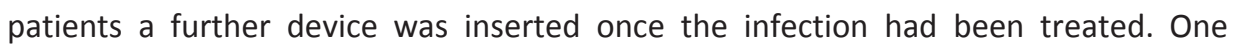

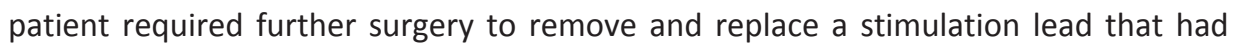

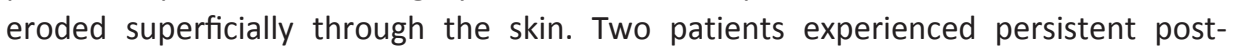

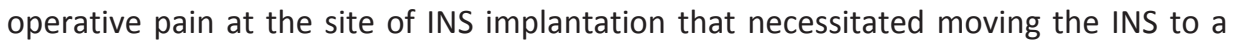

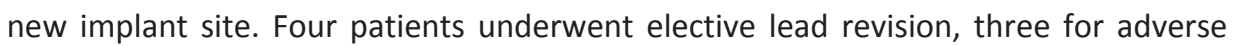

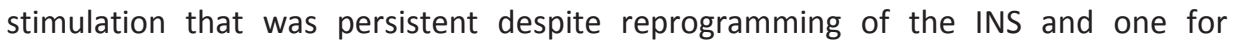

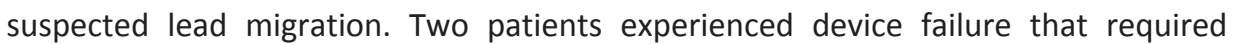

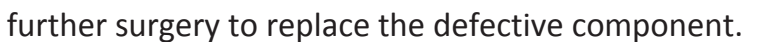

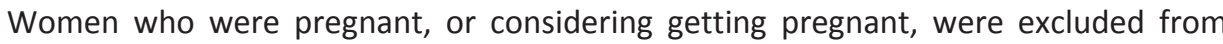

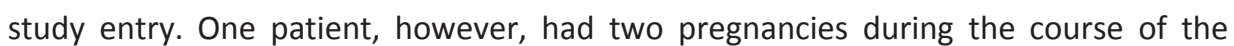

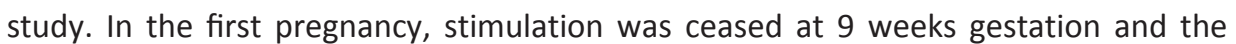

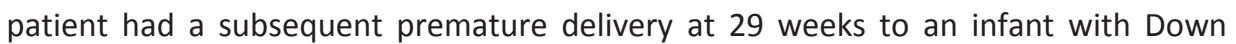

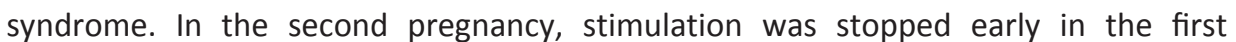
페 |

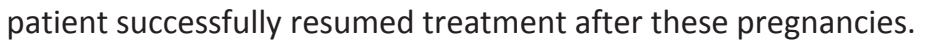

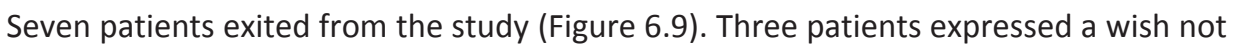

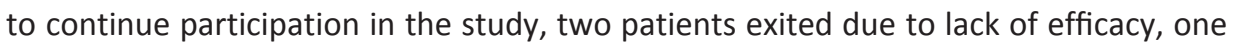

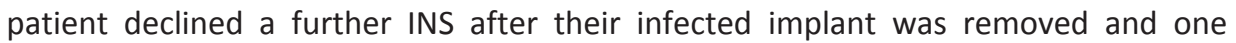

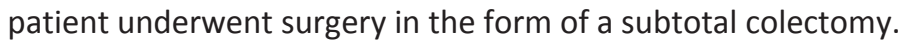




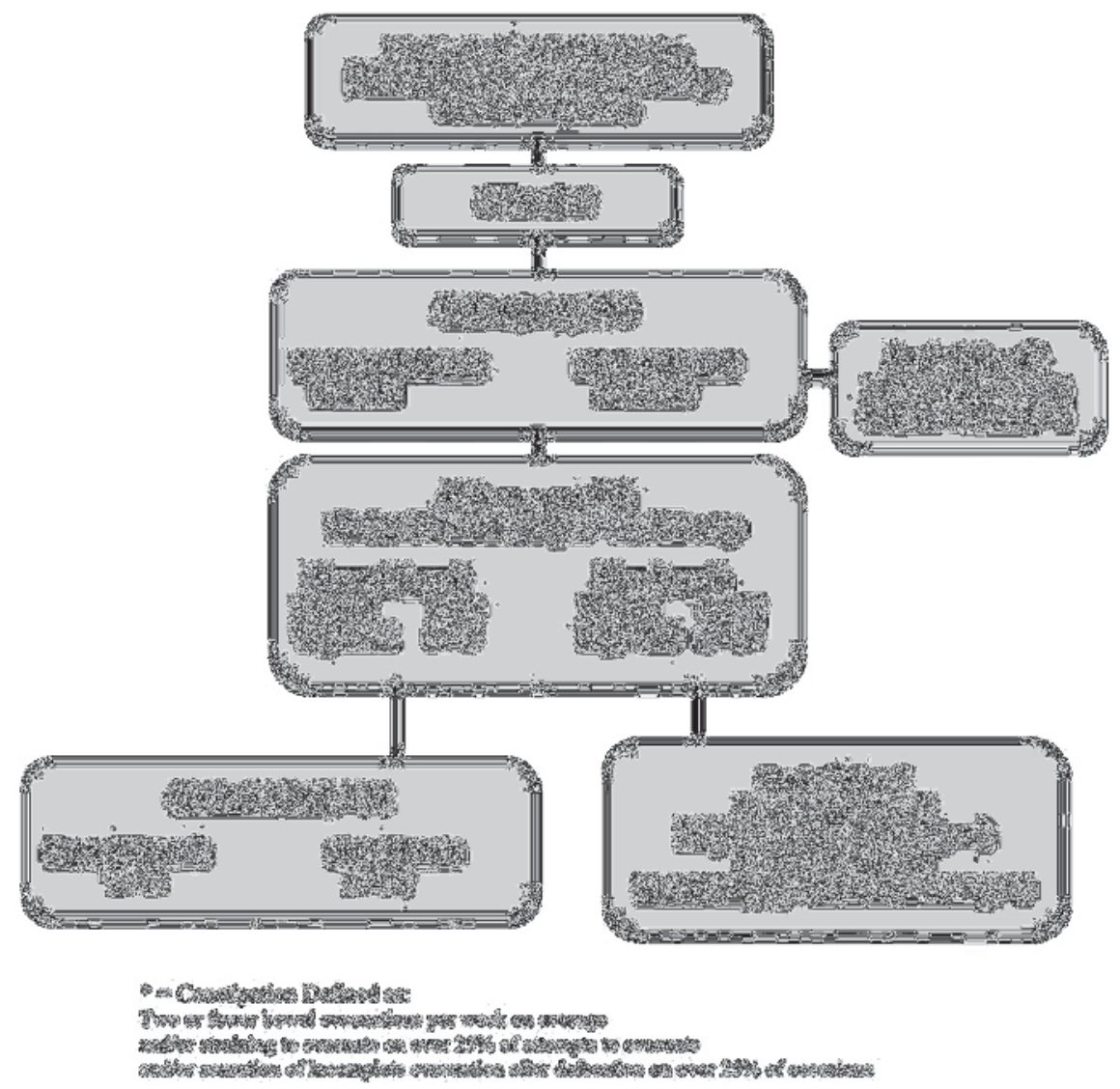

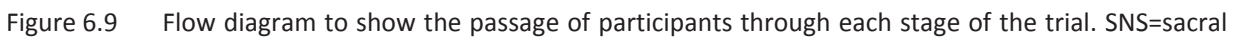

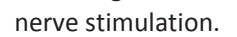

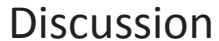

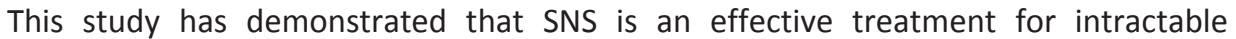

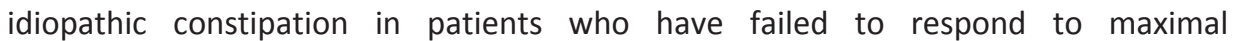

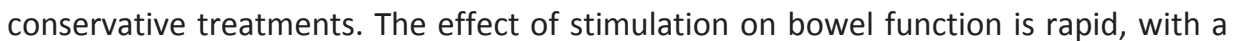

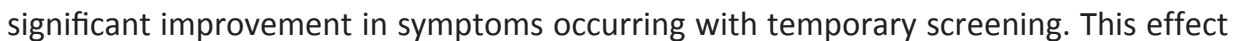

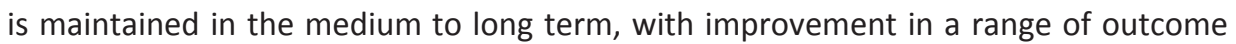

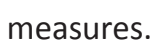

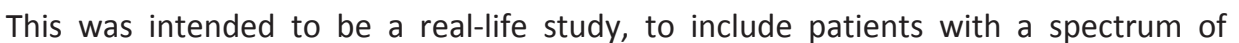

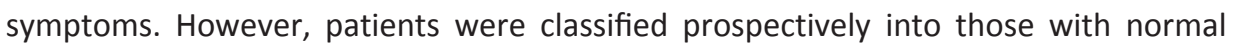

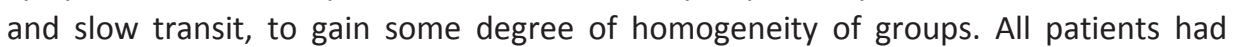




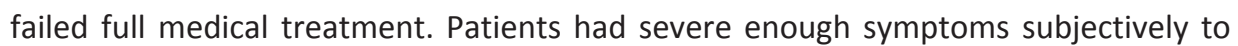

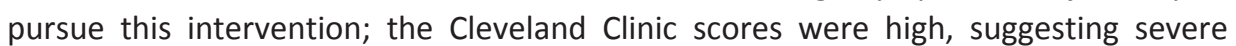

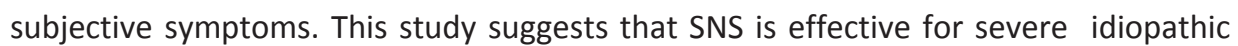

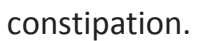

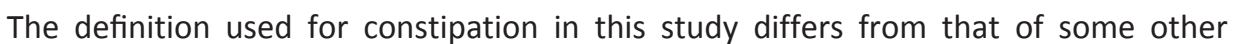

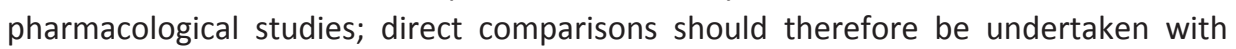

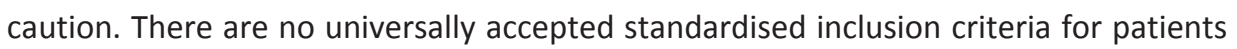

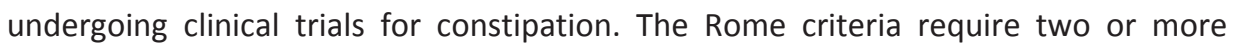

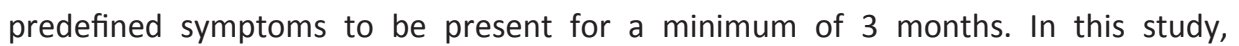

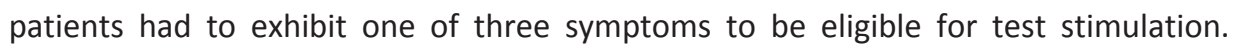

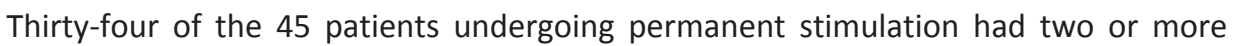

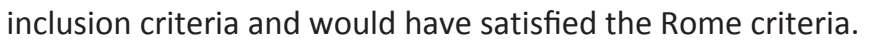

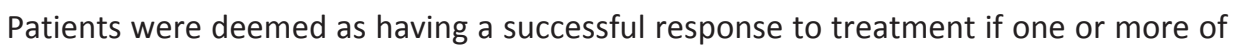

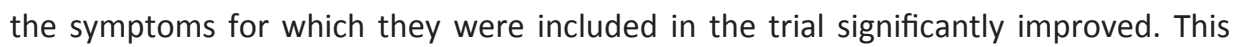

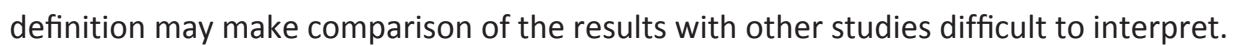

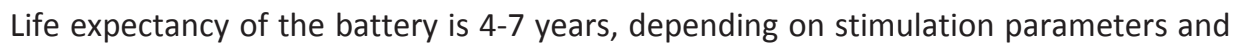

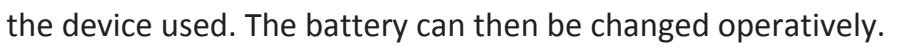

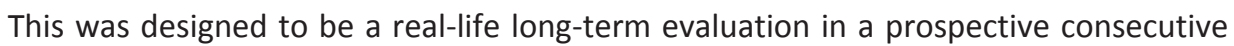

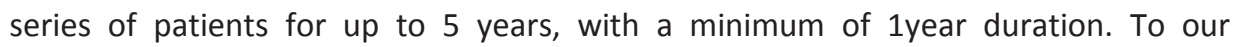

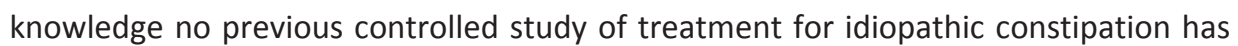

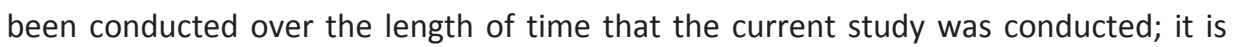

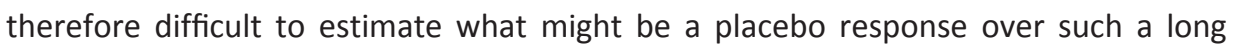

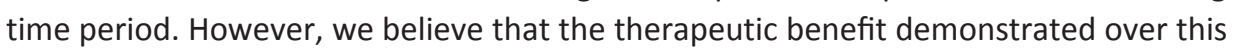

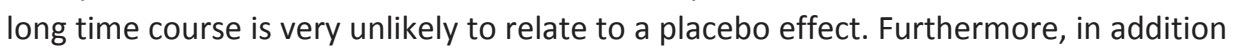

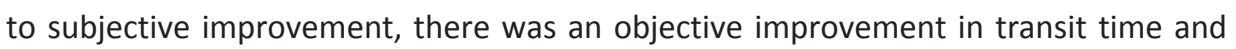

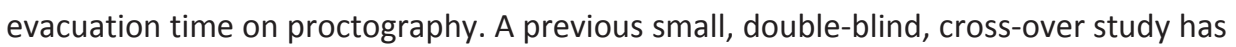

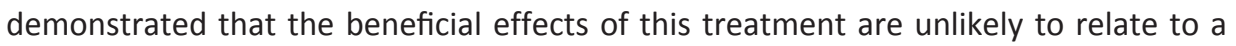

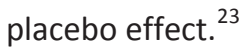

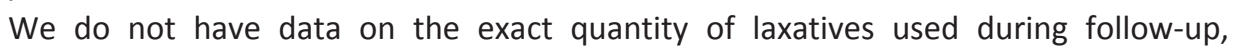

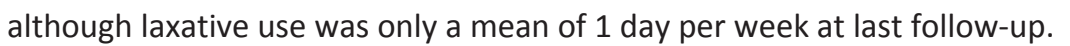

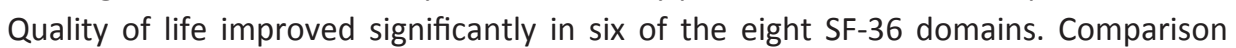

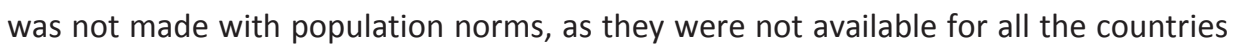

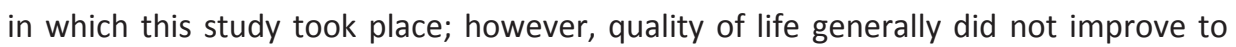

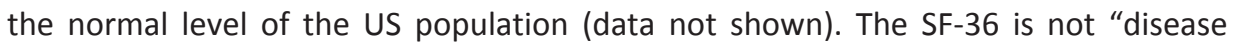

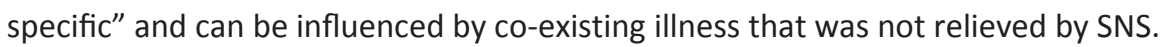

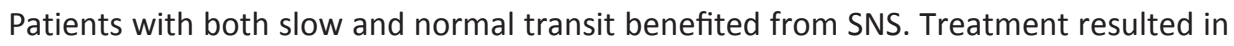

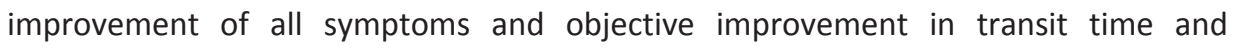

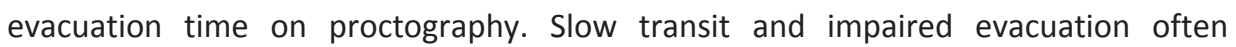

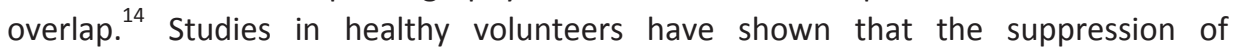

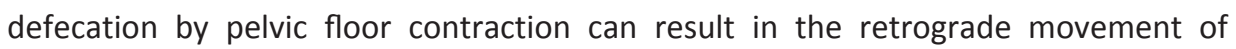




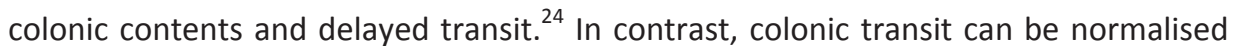

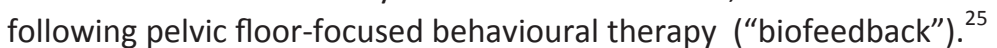

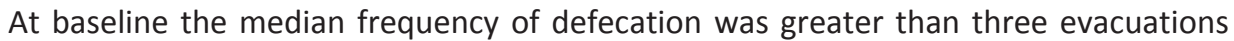

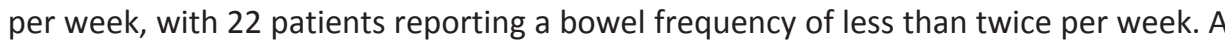

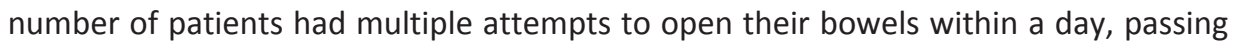

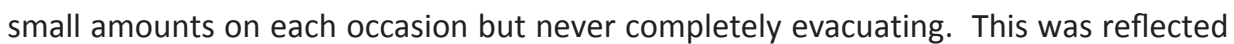

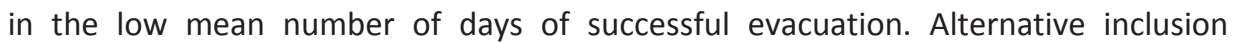

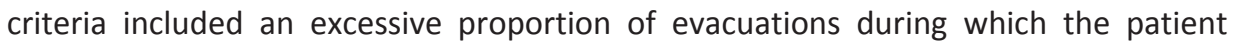

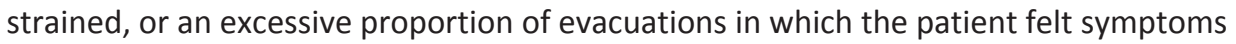

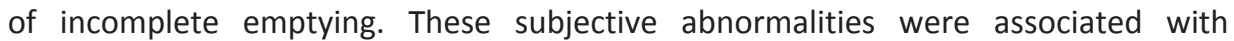

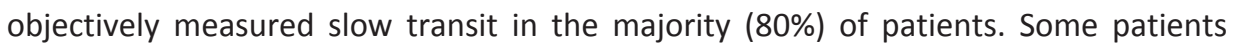

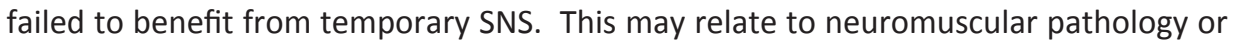

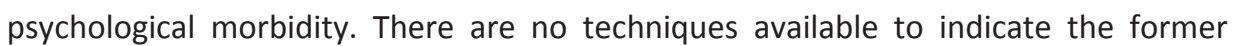

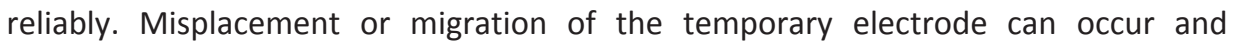

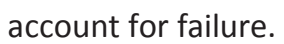

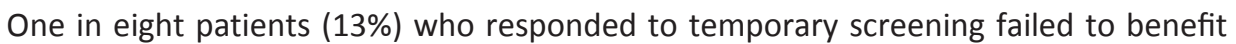

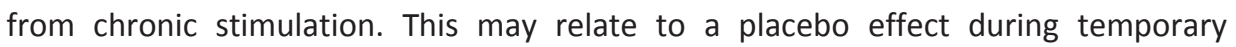

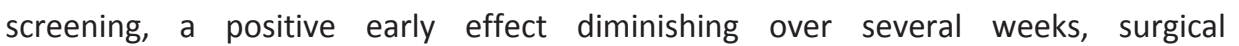

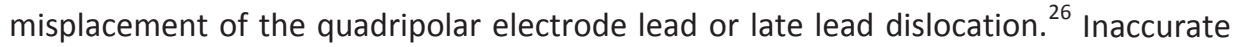

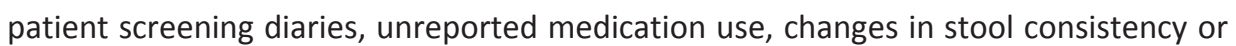

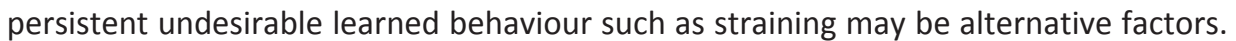

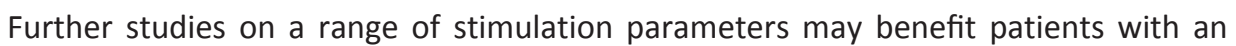

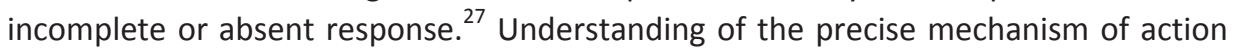

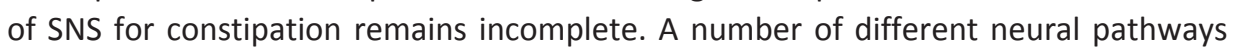

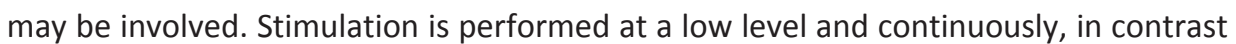

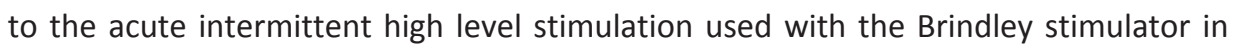

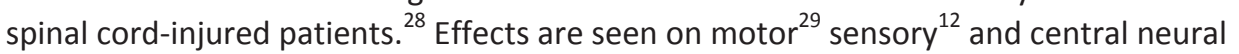

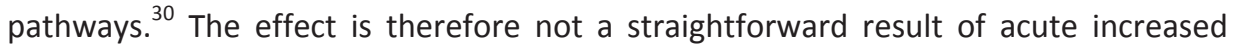

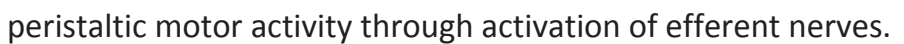

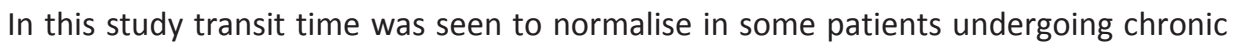

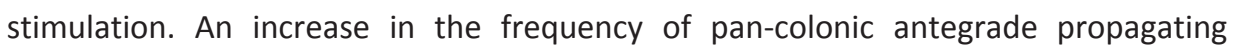

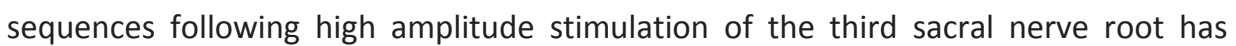

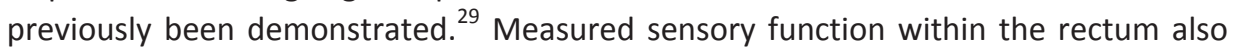

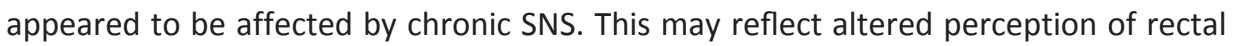

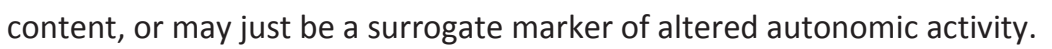

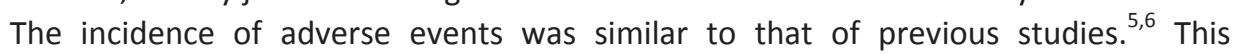

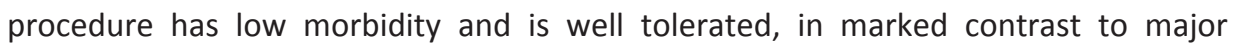

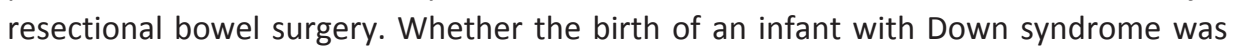

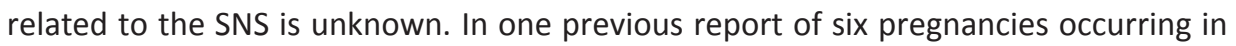

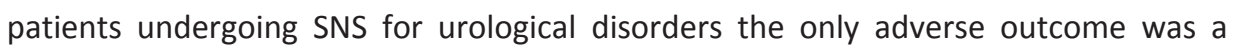

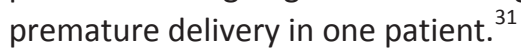




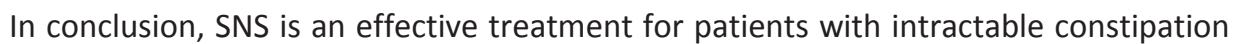

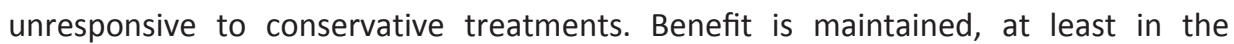

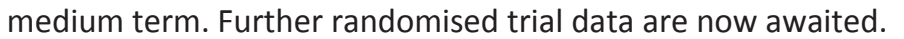




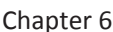

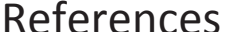

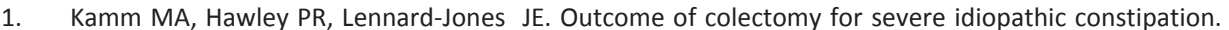

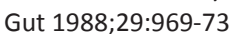

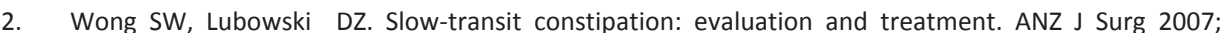

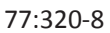

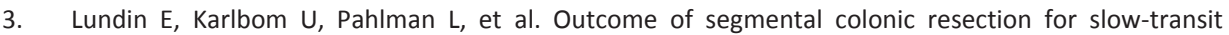

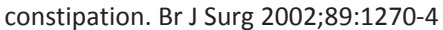

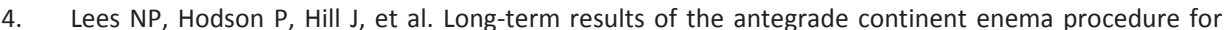

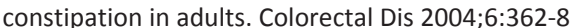

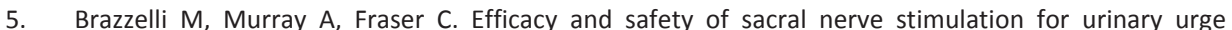

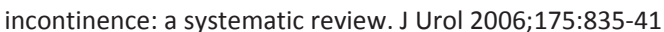

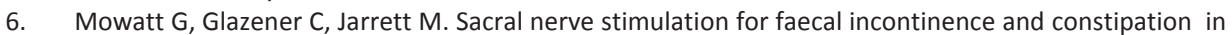

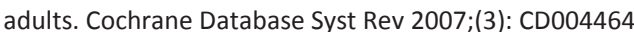

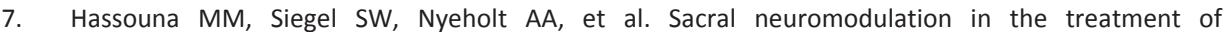

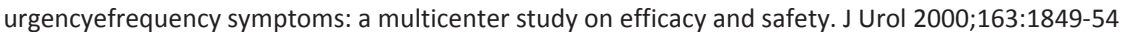

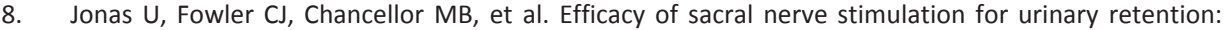

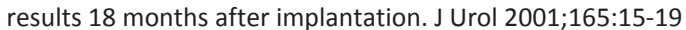

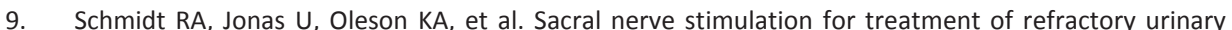

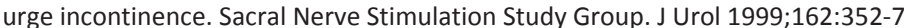

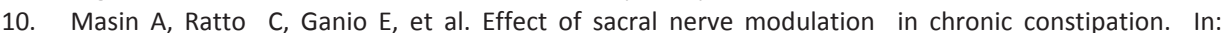

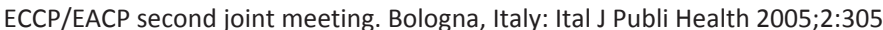

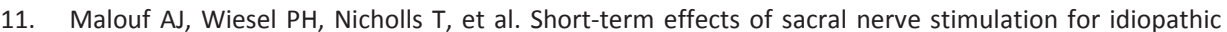

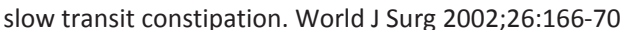

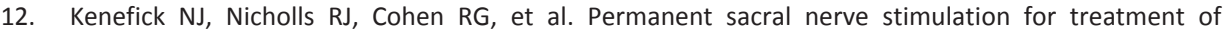

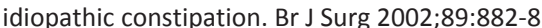

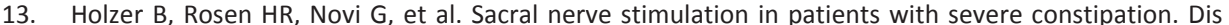

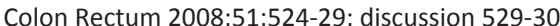

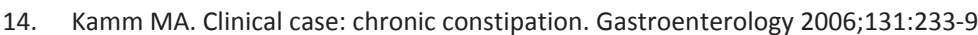

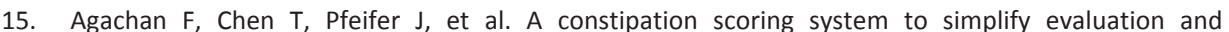

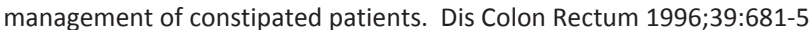

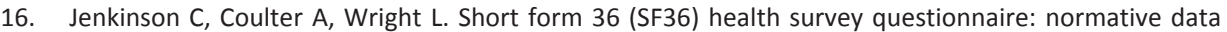

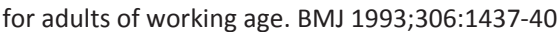

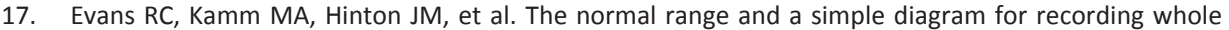

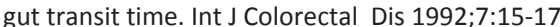

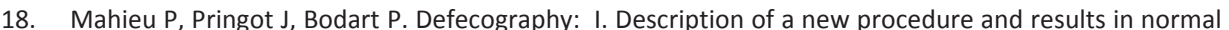

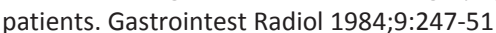

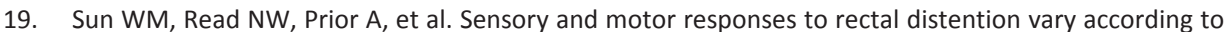

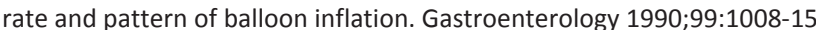

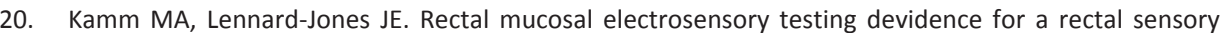

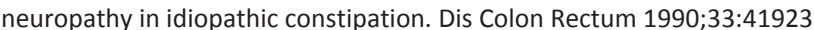

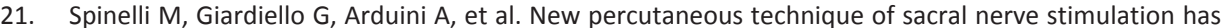

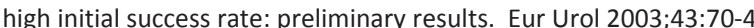

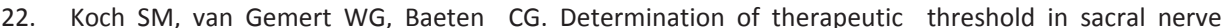

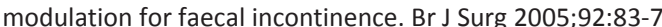

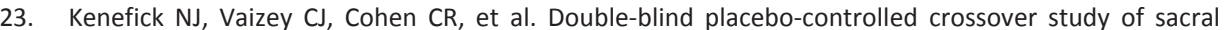

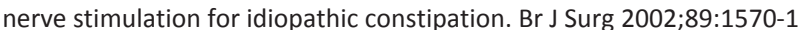

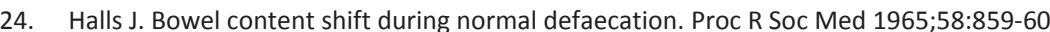

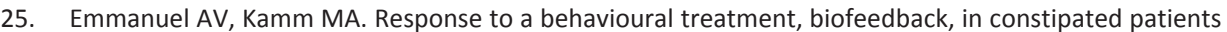

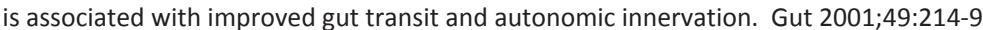

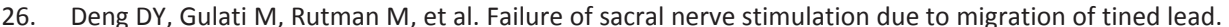

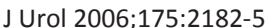

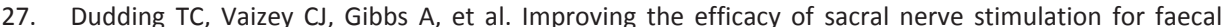

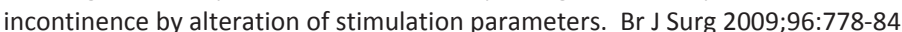




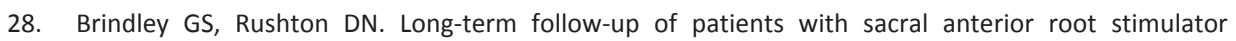

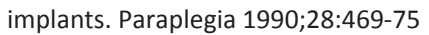

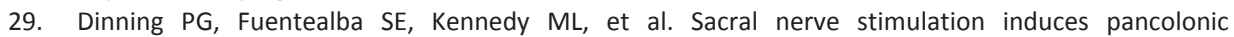

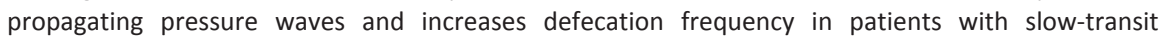

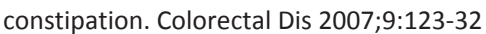

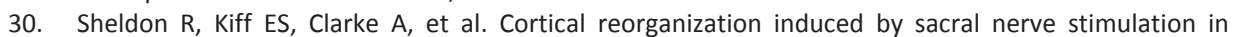

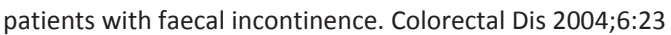

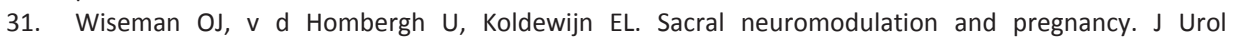

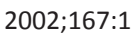




\section{?ㅇ?요요?}

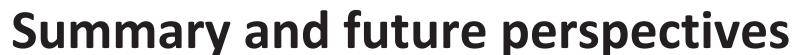




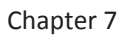




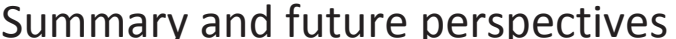

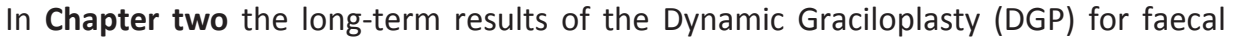

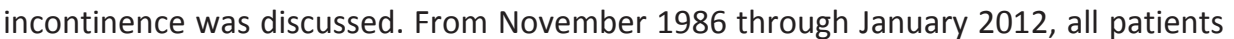

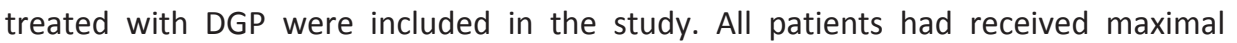

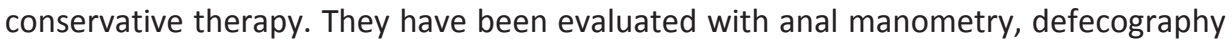

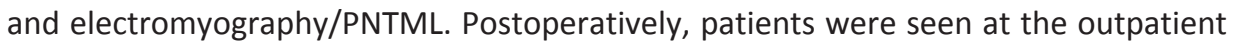

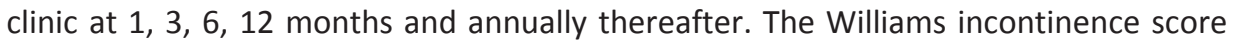

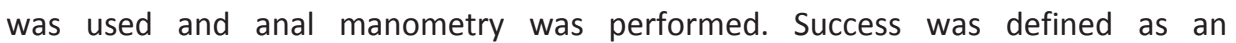

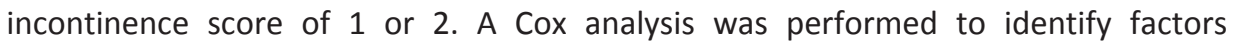

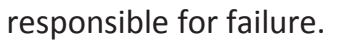

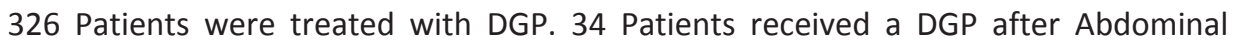

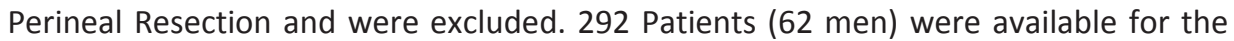

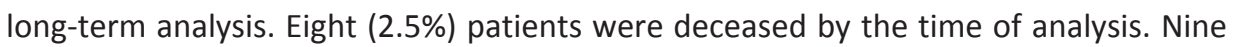

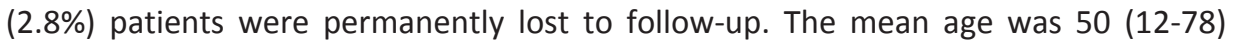

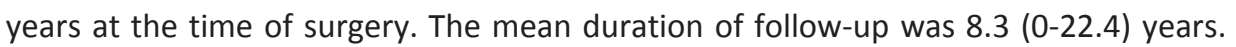

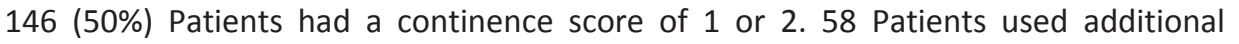

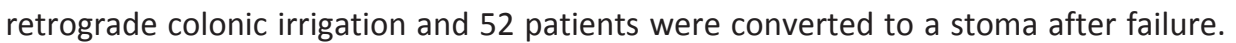

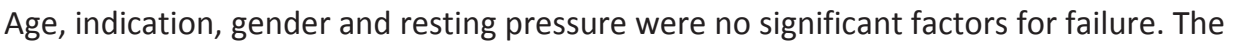

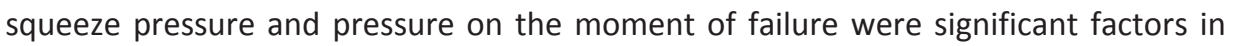

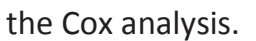

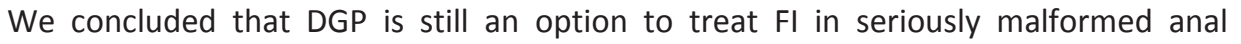

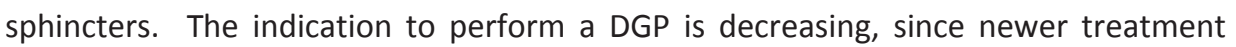

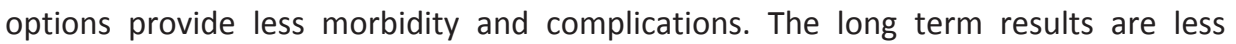

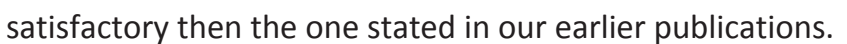

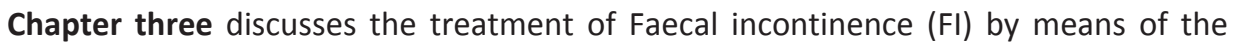

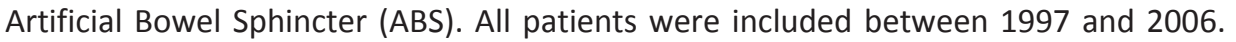

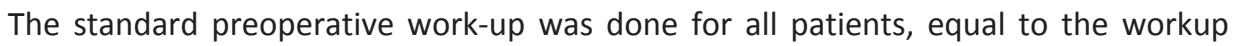

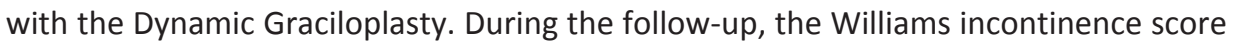

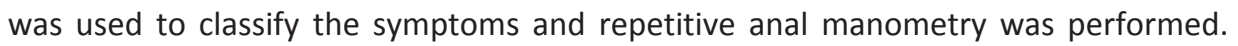

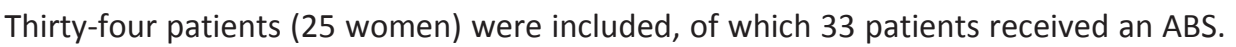

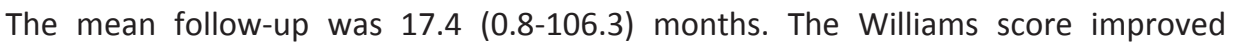

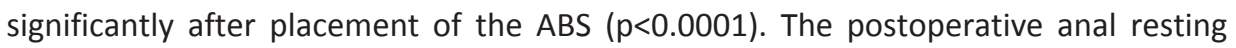

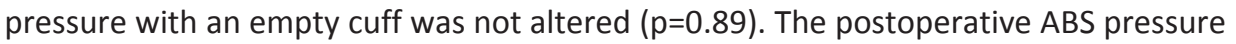

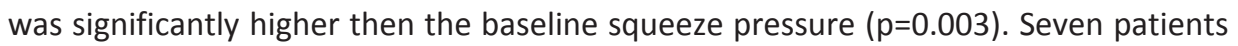

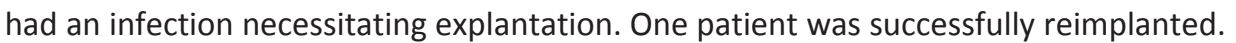

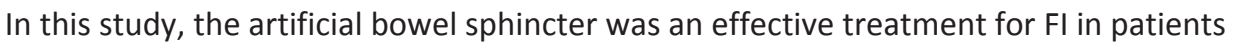

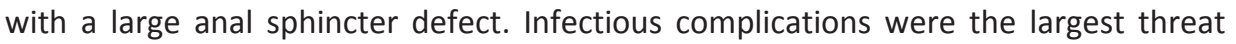

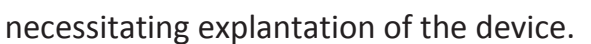

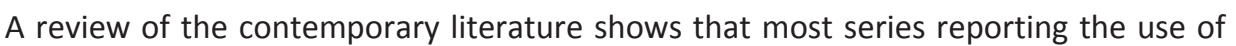

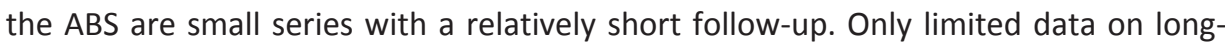




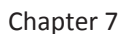

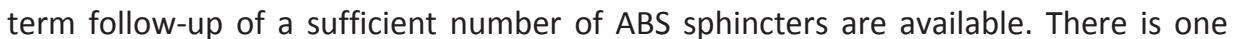

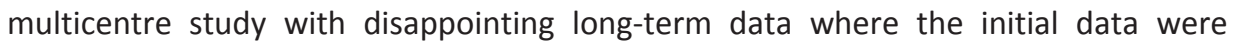

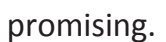

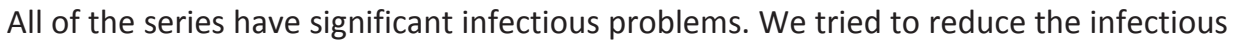

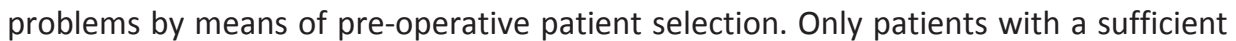

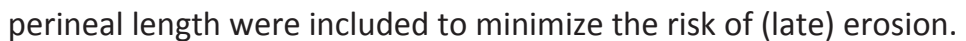

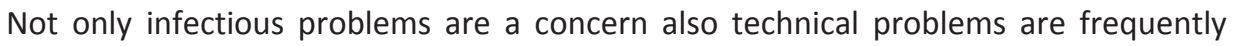

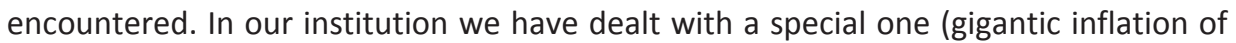

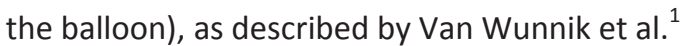

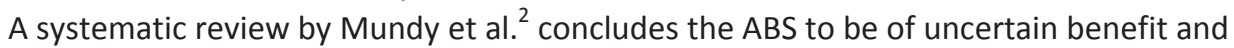

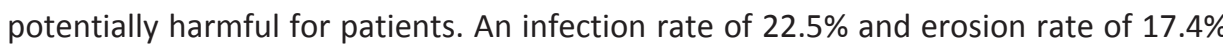

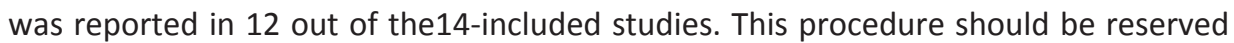

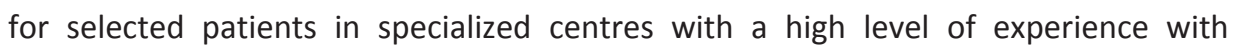

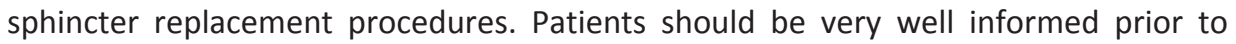

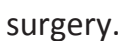

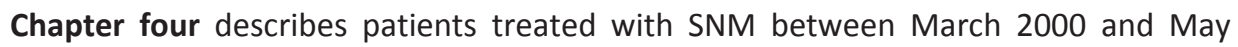

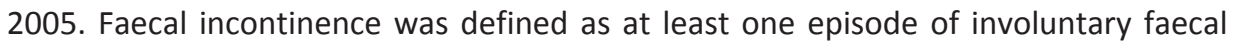

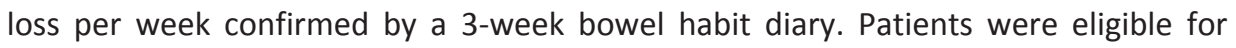

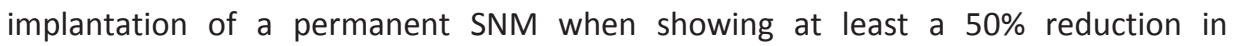

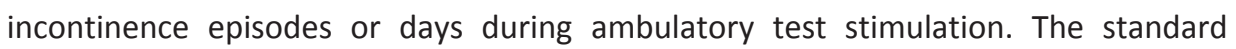

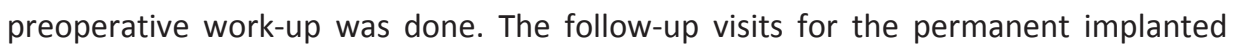

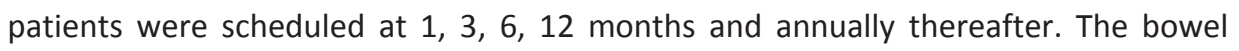

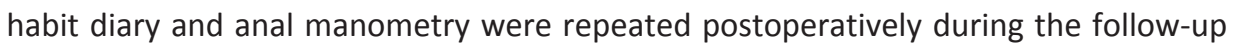

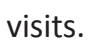

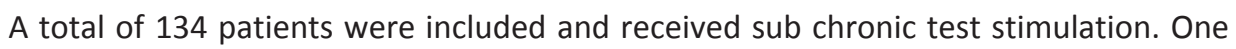

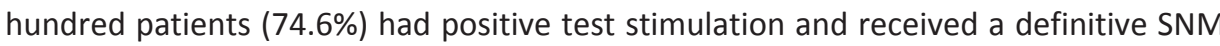

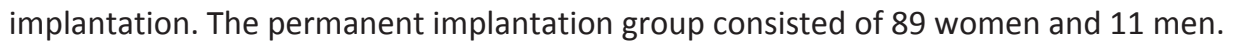

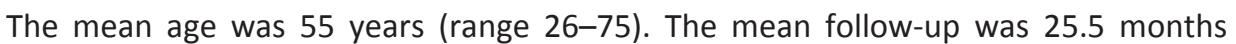

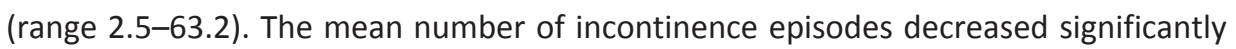

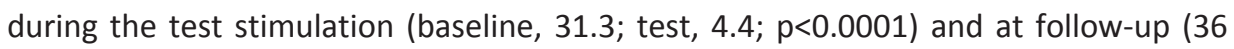

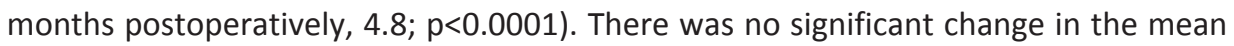

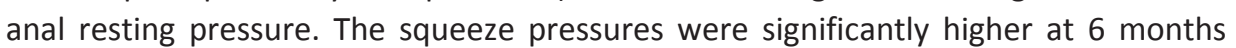

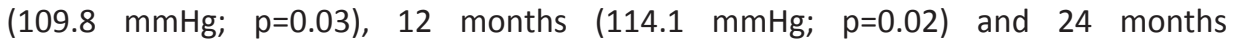

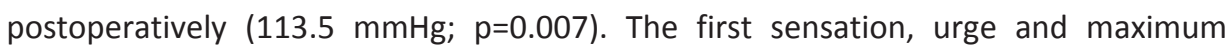

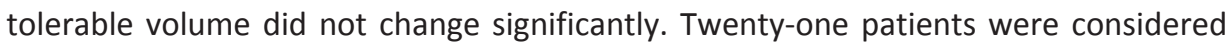

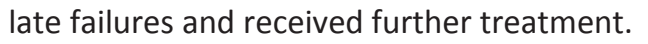

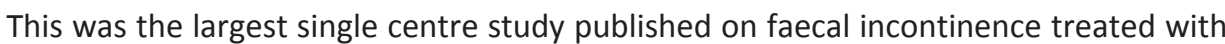

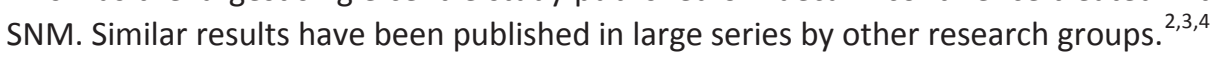




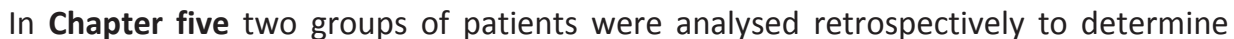

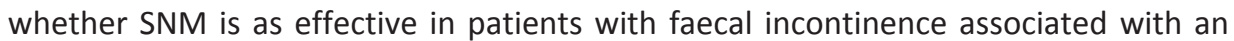

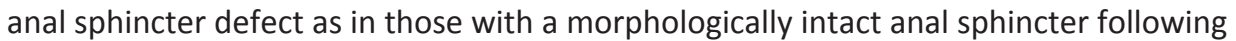

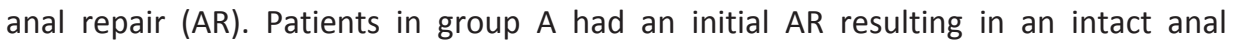

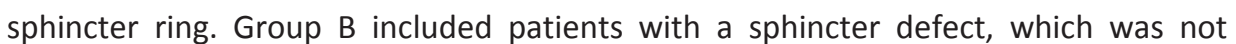

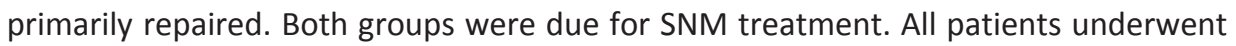

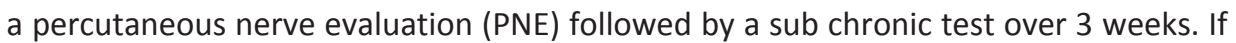

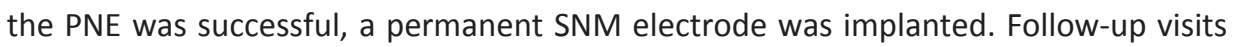

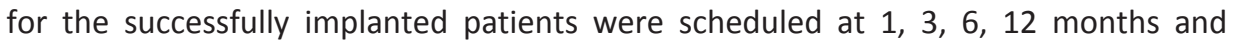

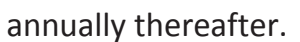

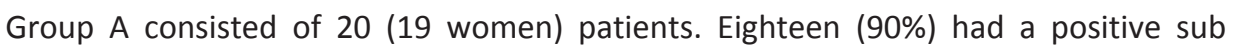

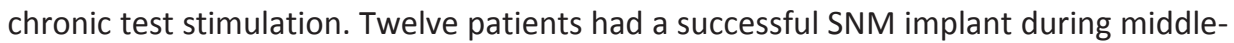

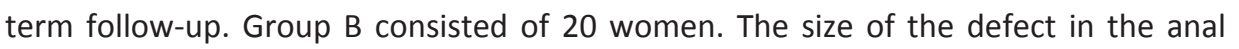

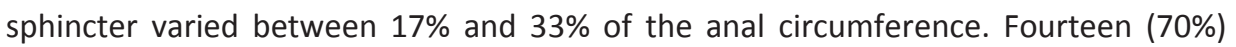

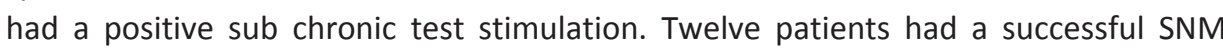

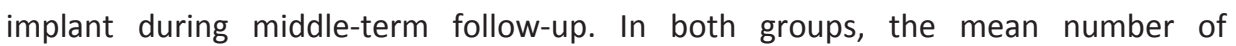

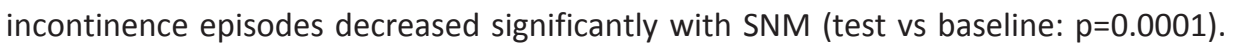

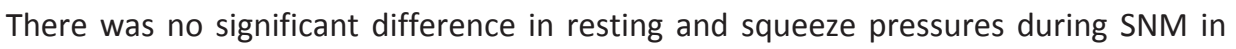

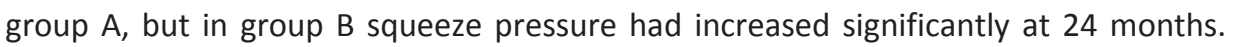

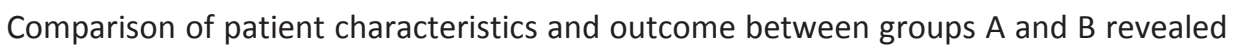

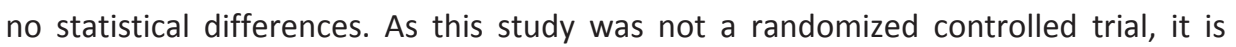

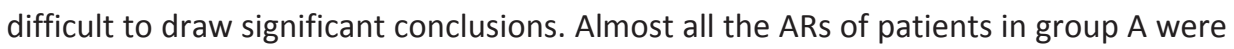

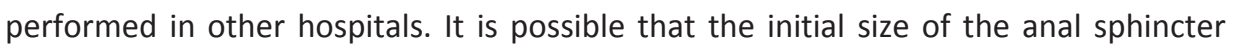

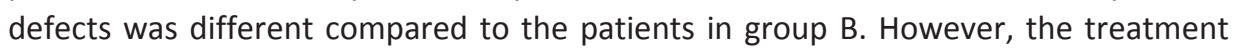

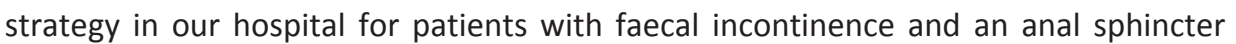

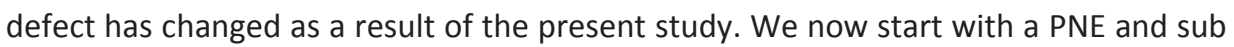

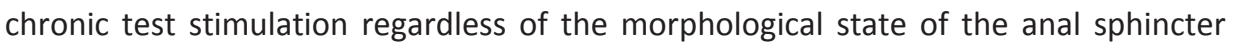

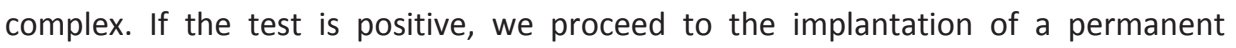

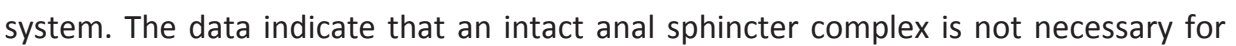

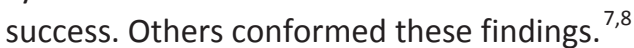

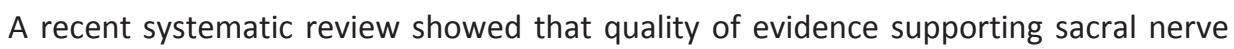

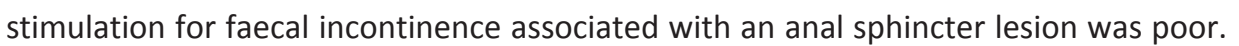

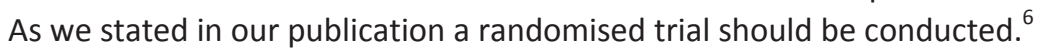

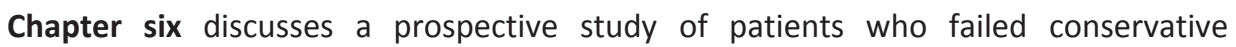

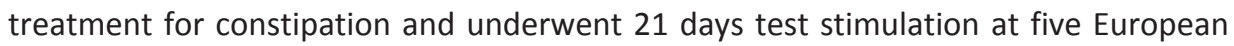

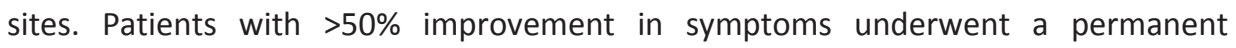

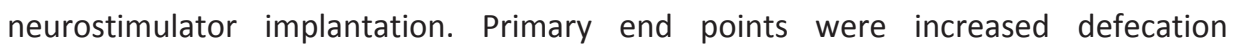

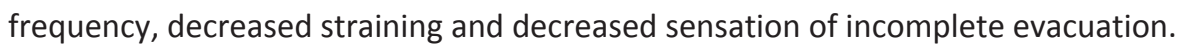

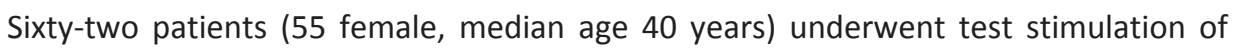

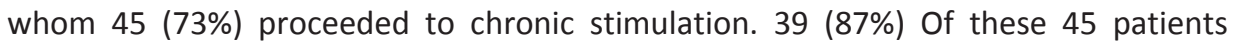




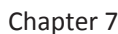

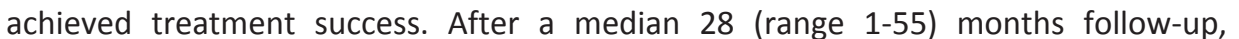

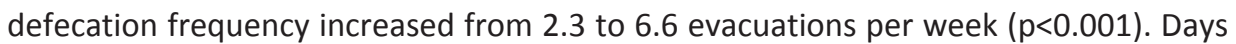

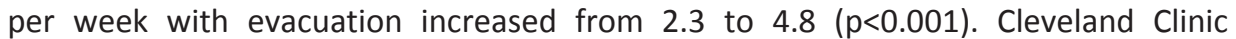

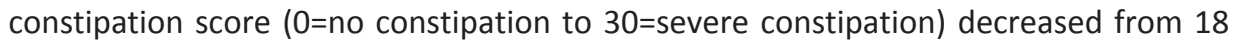

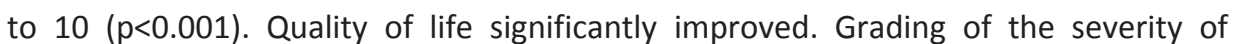

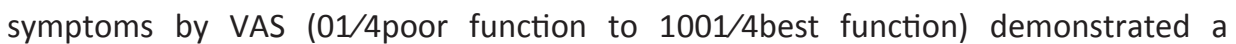

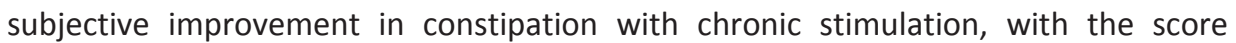

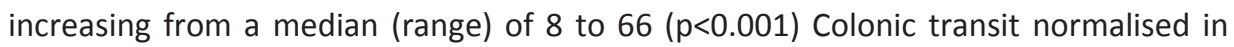

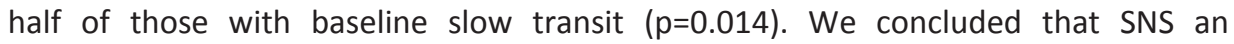

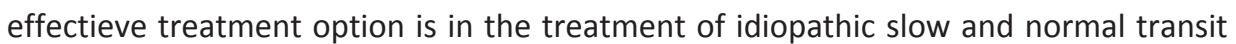

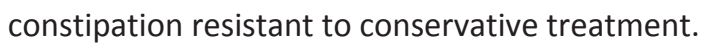

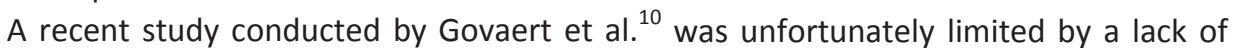

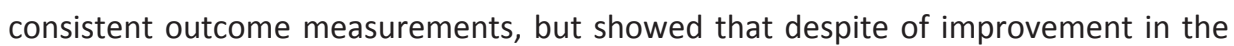

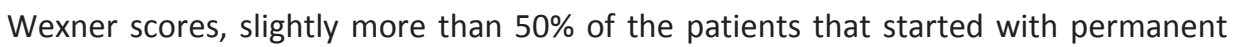

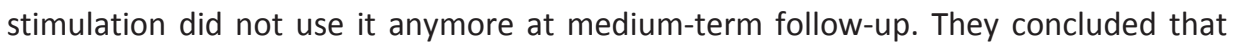

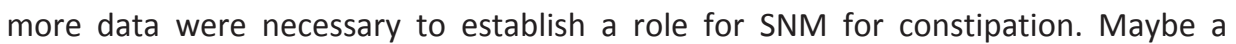

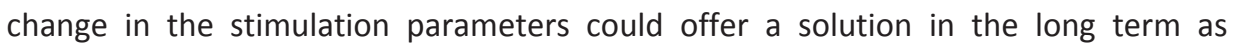

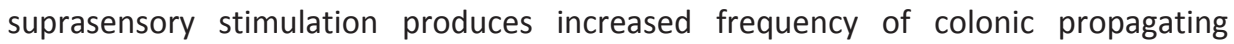

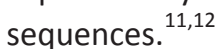

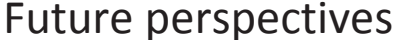

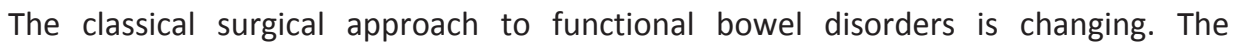

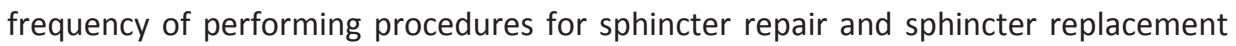

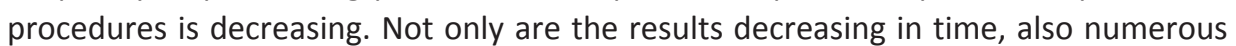

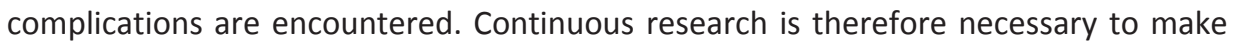

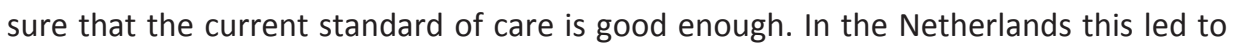

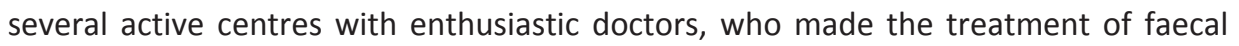

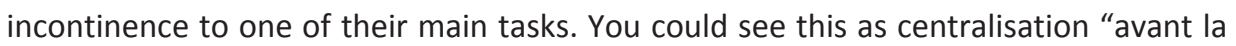

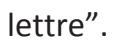

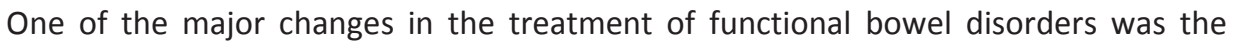

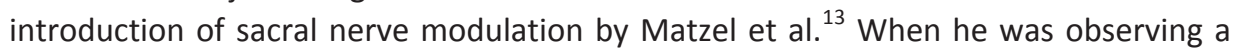

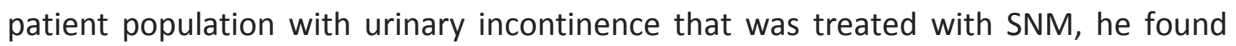

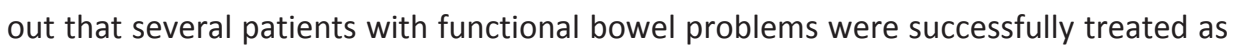

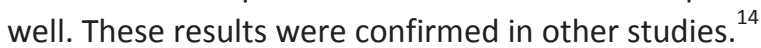

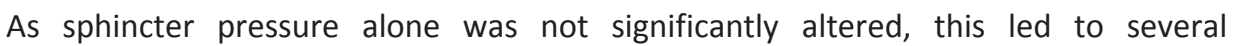

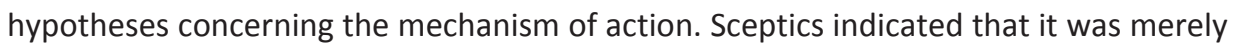

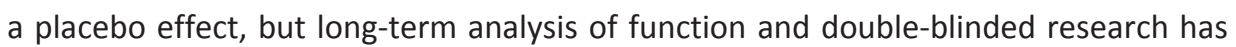

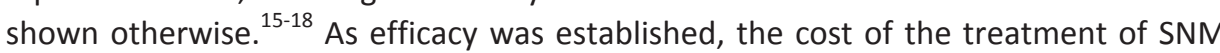

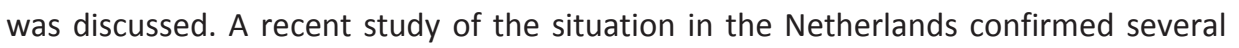


[?]

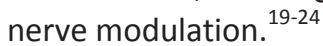

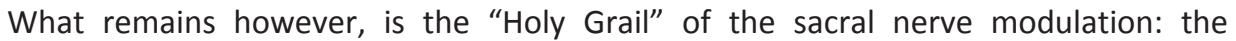

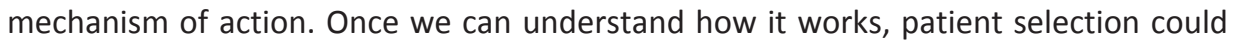

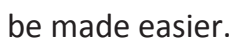

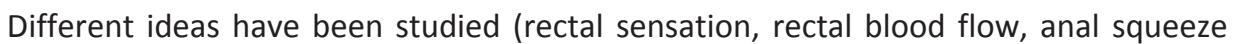

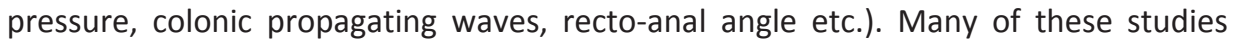

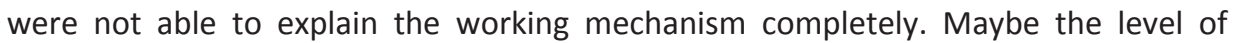

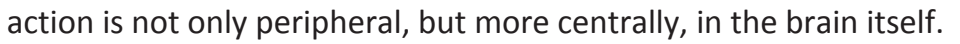

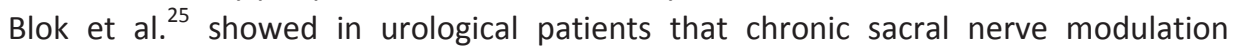

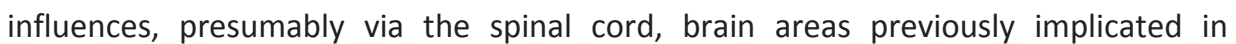

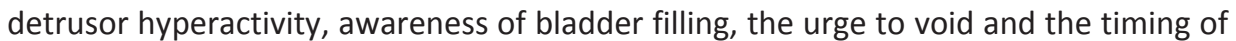

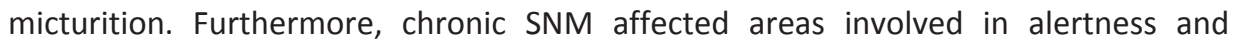

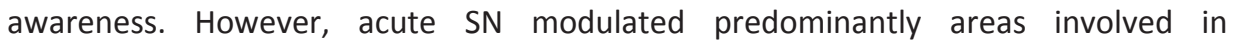

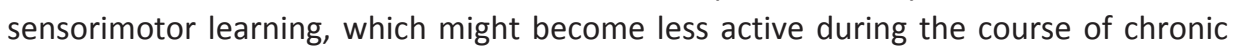

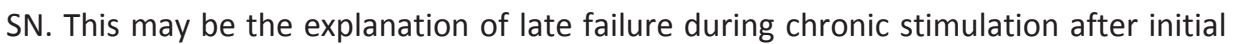

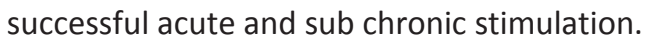

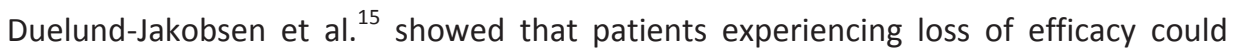

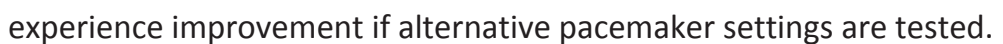

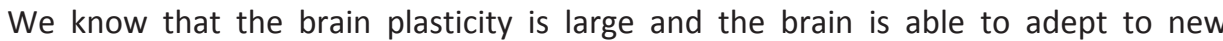

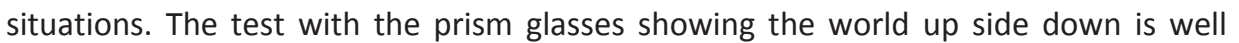

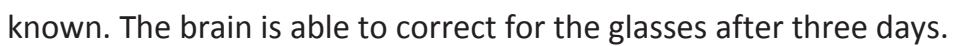

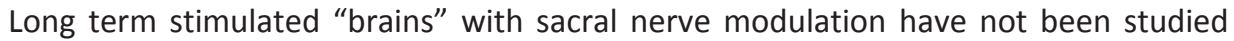

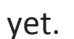

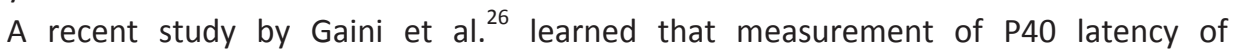

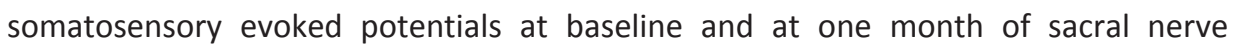

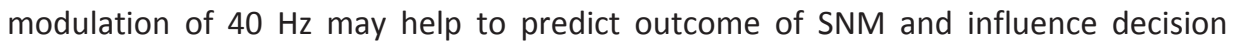

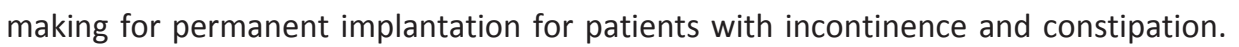

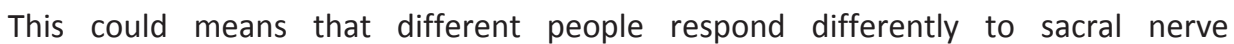

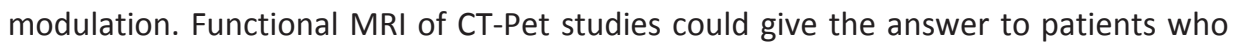

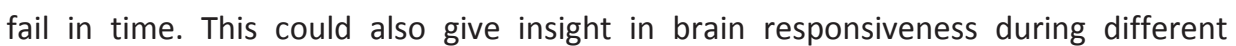

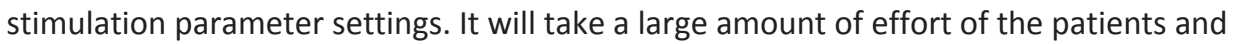

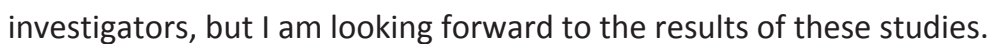




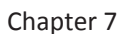

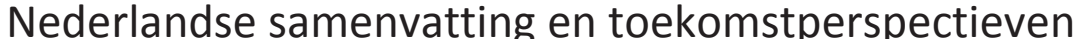

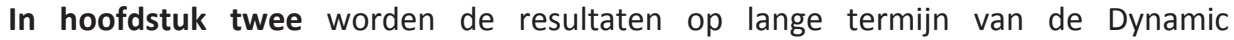

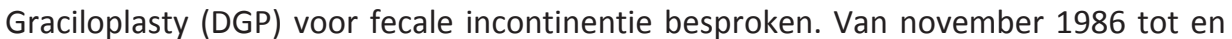

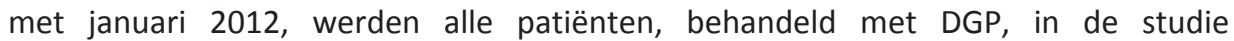

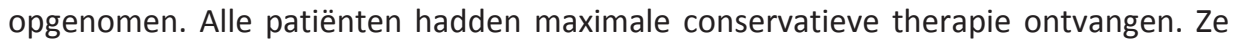

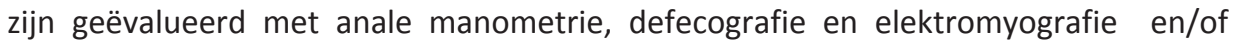

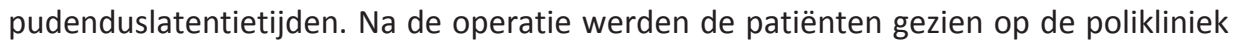

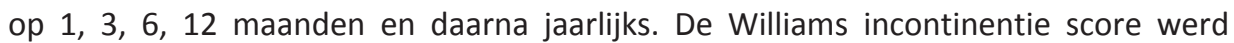

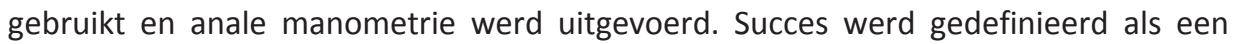

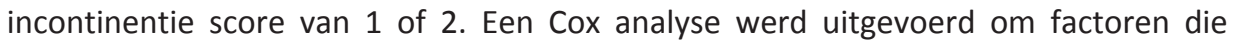

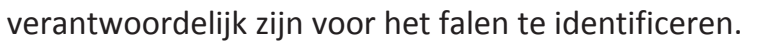

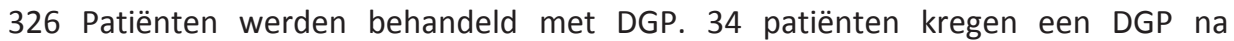

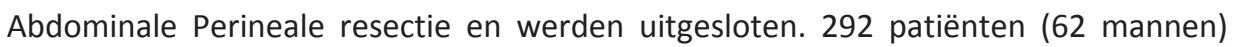

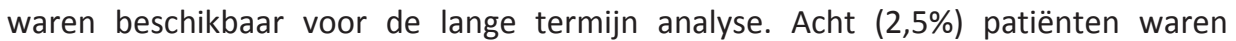

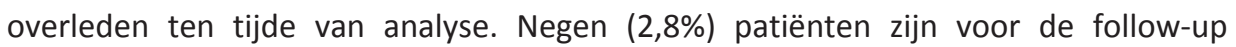

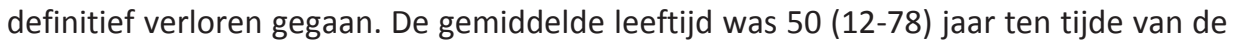

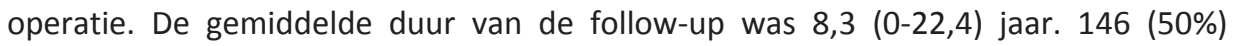

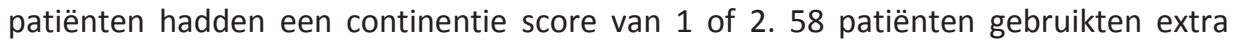

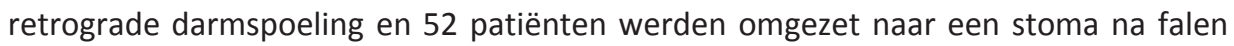

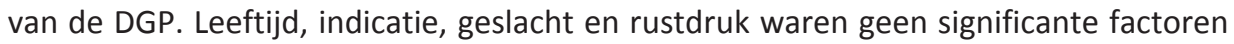

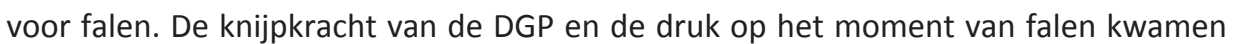

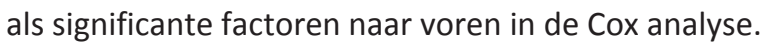

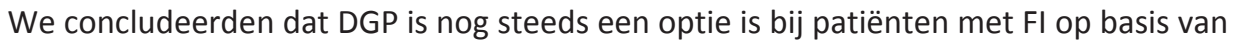

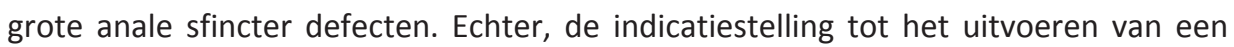

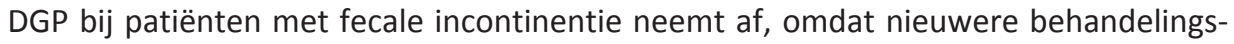

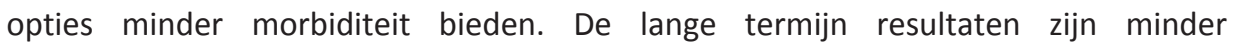

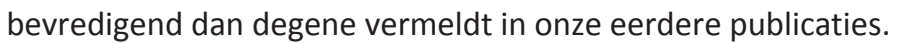

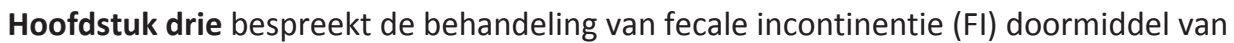

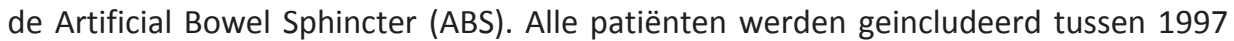

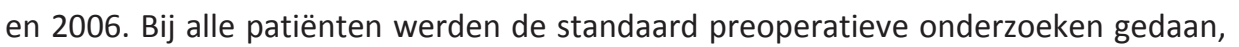

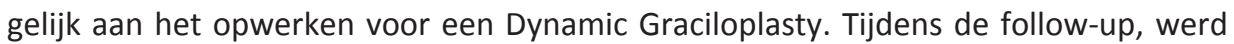

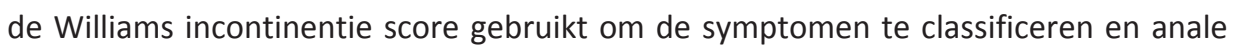

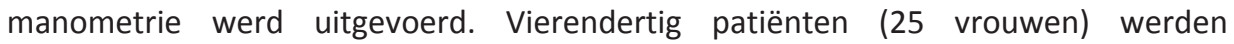

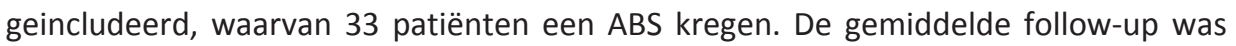

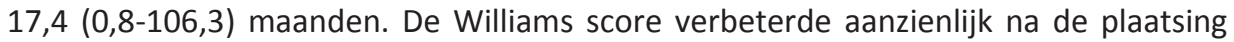

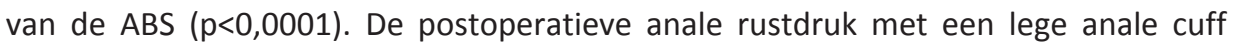

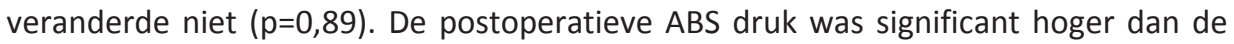

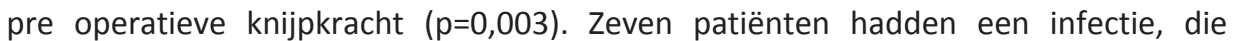

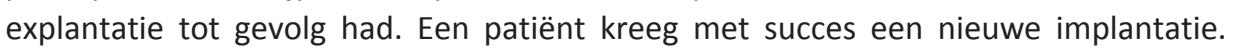

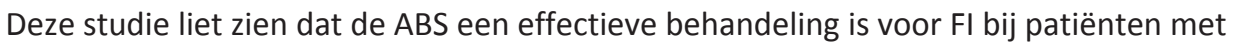




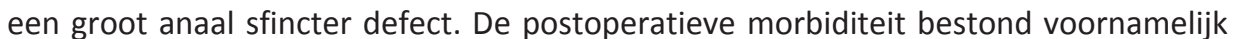

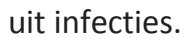

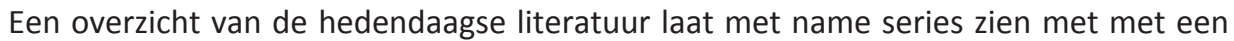

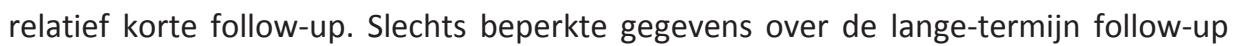

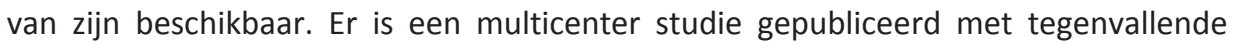

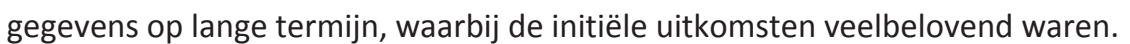

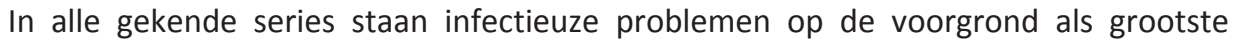

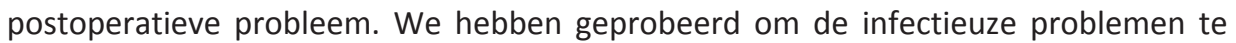

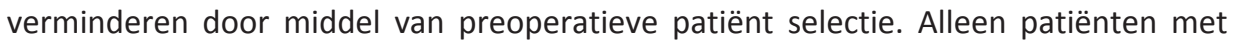

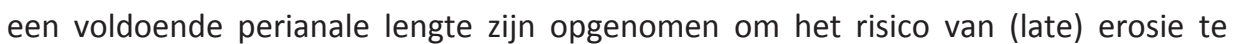

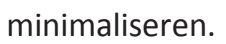

[?

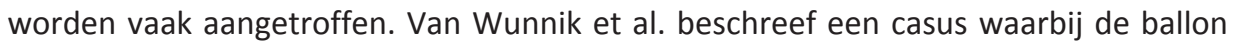

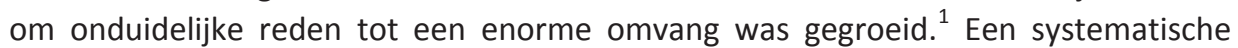

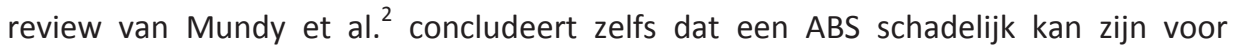

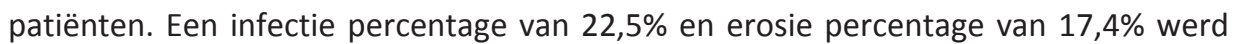

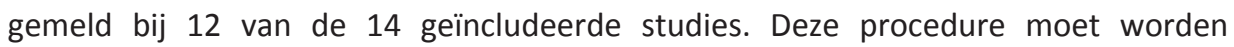

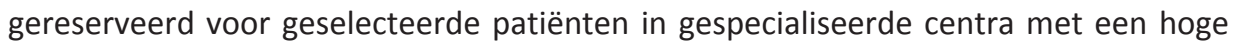

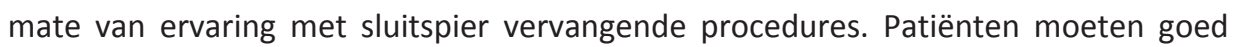

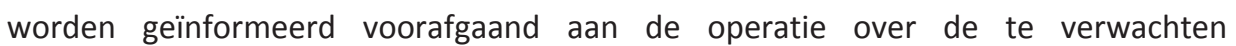

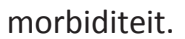

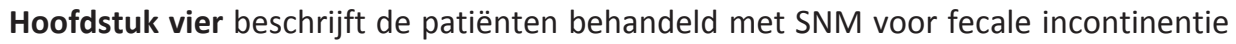

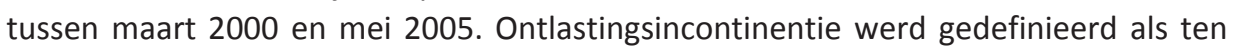

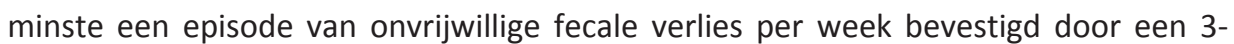

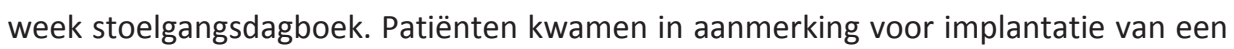

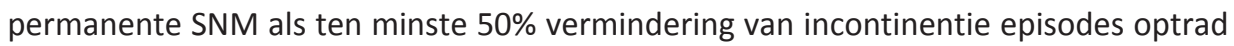

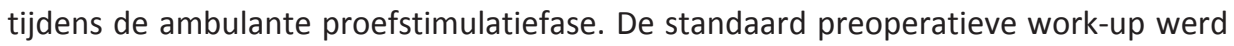

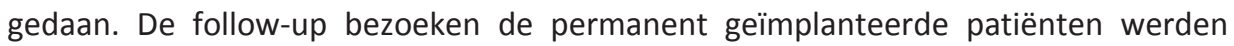

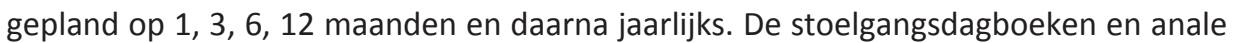

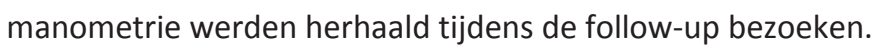

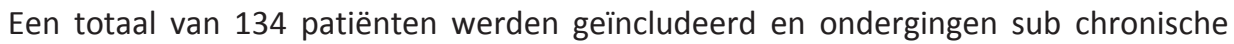

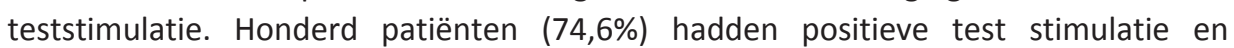

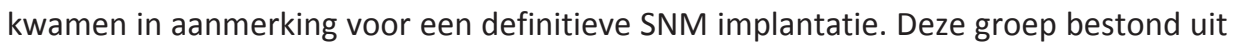

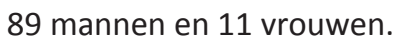

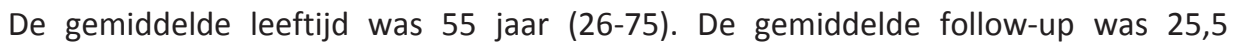

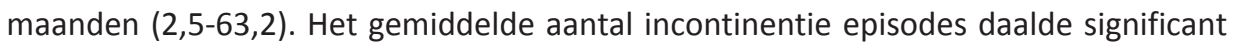

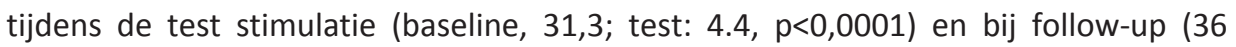

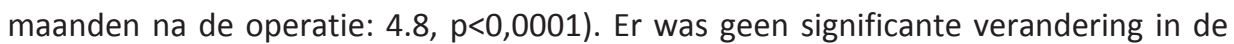

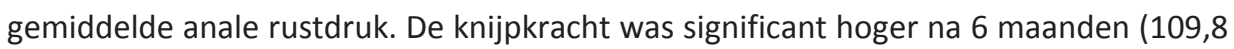

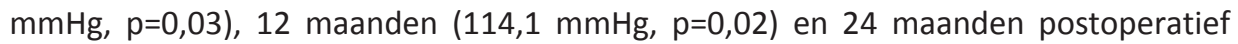




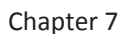

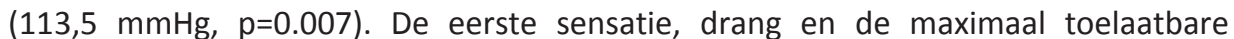

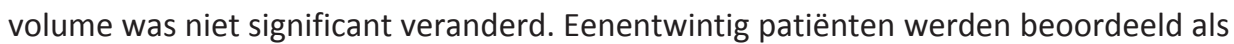

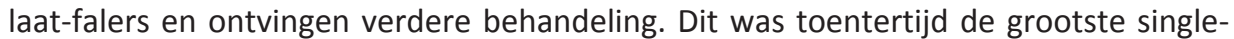

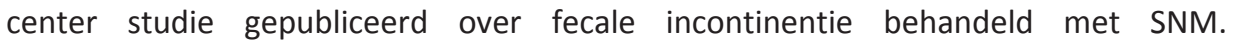

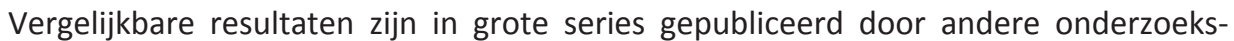

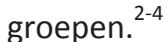

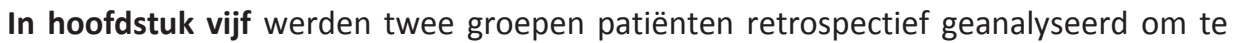

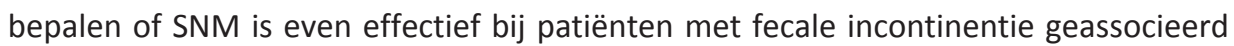

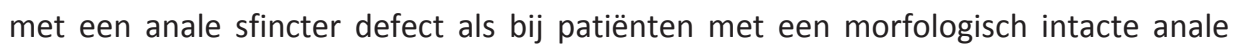

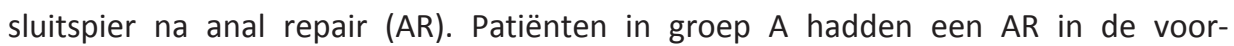

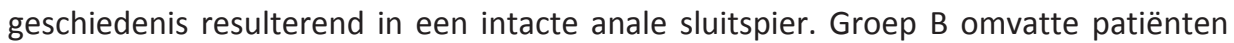

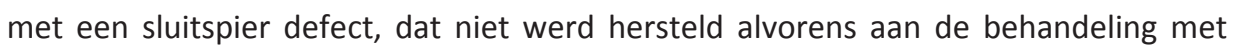

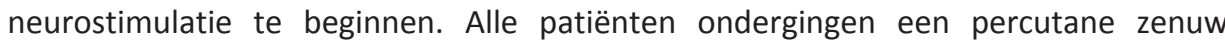

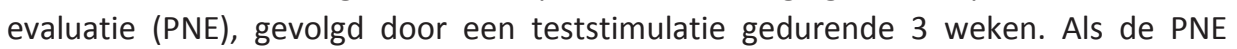

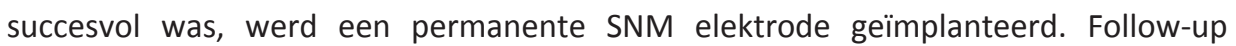

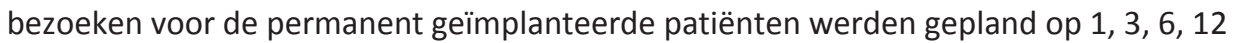

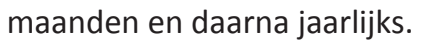

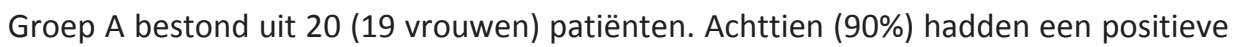

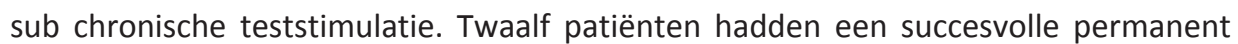

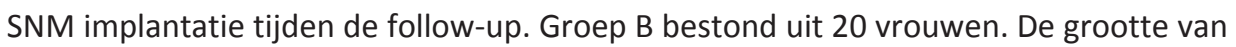

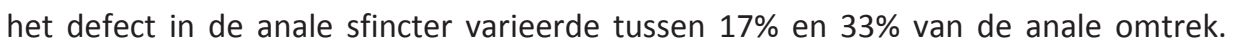

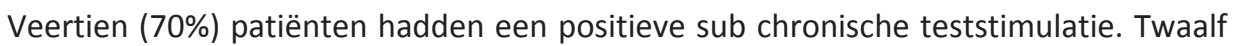

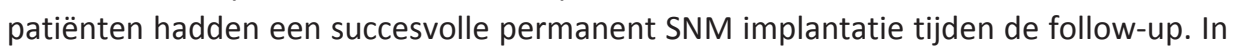

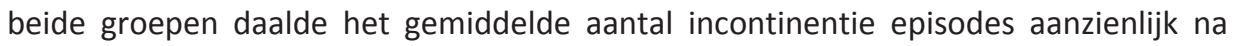

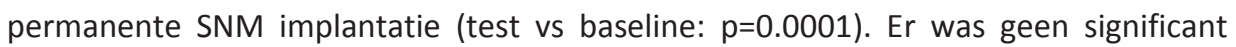

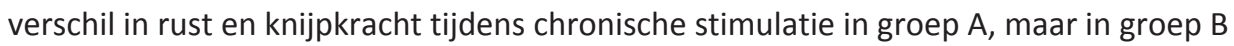

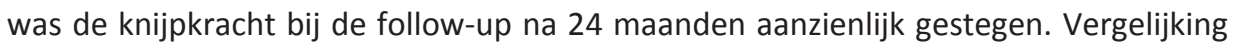

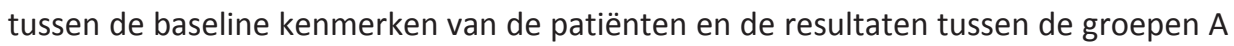

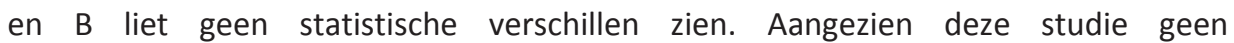

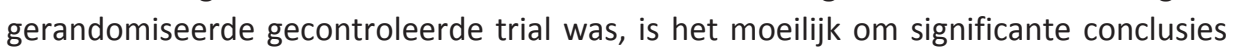

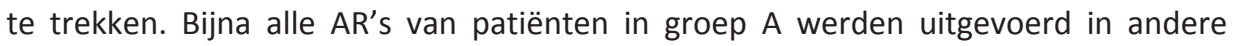

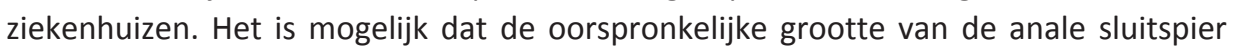

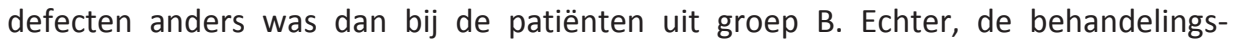

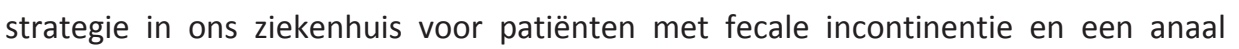

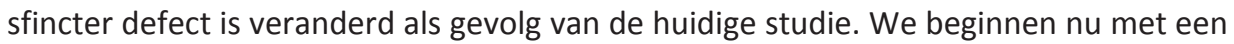

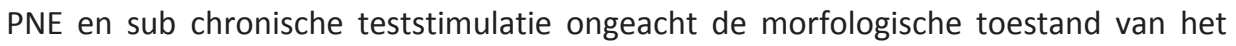

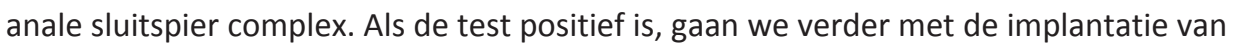

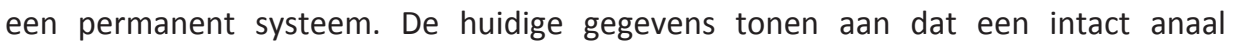

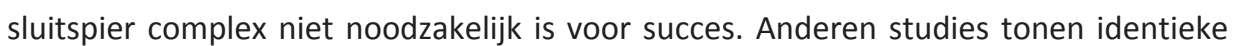

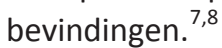




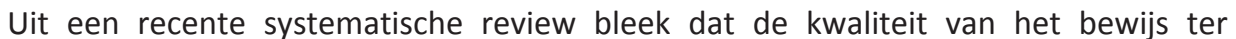

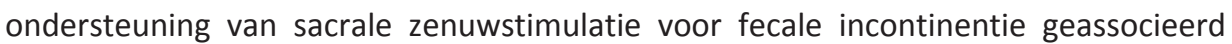

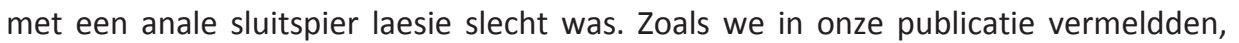

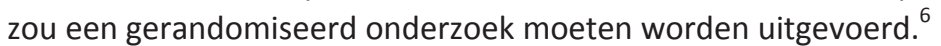

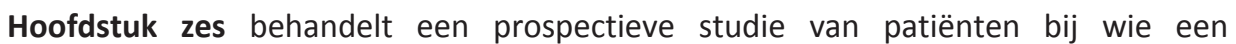

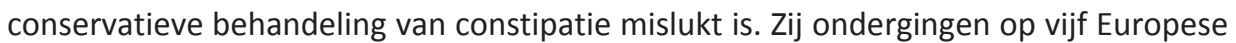

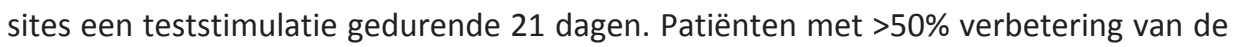

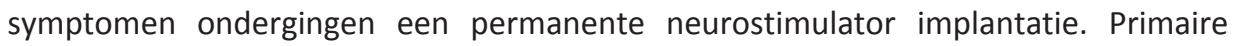

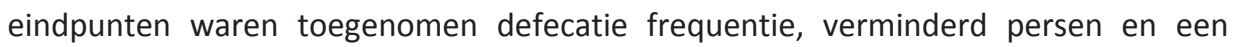

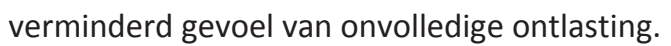

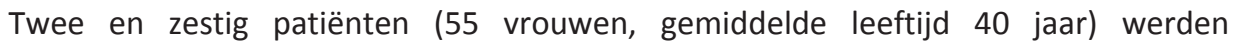

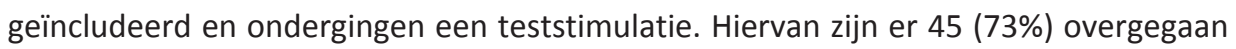

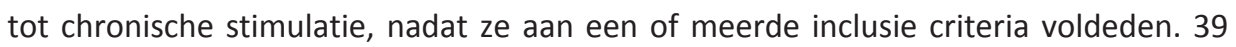

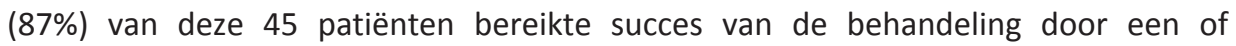

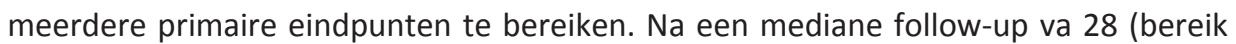

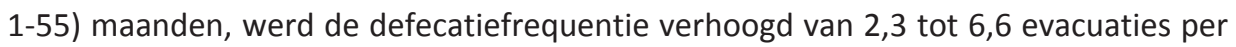

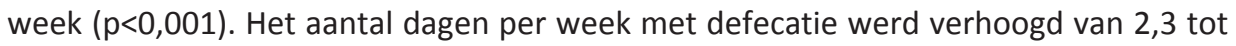

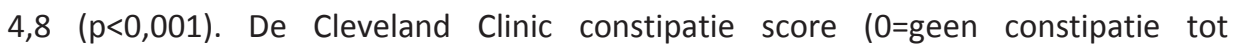

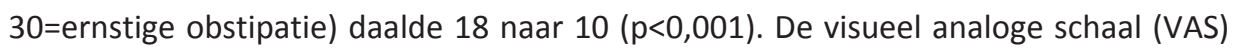

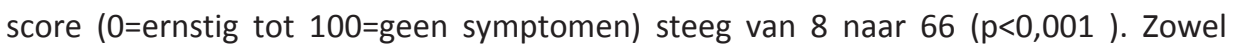

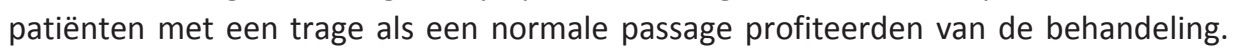

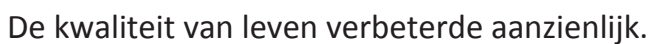

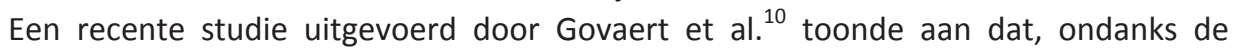

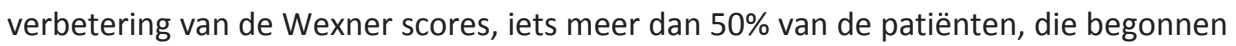

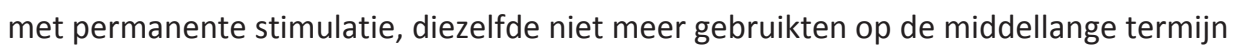

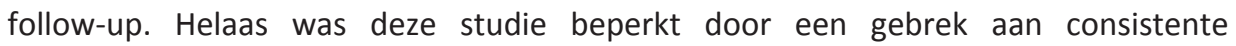

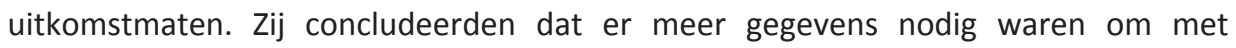

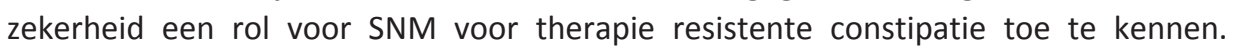

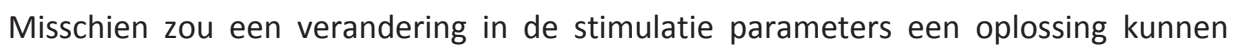

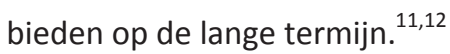

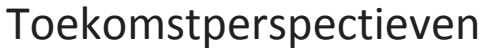

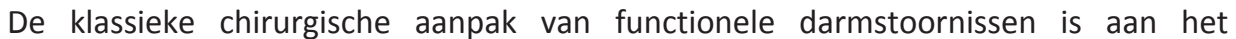

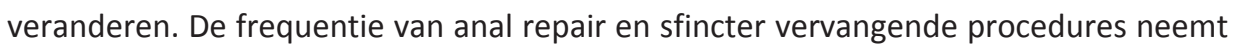

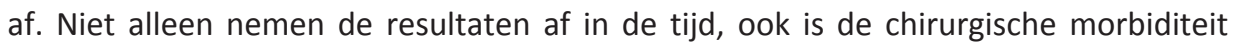

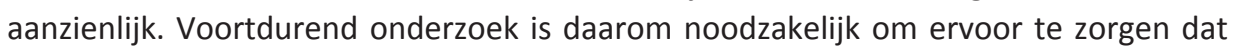

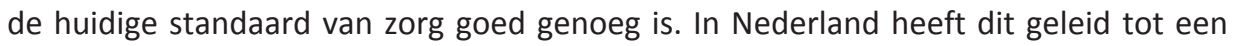

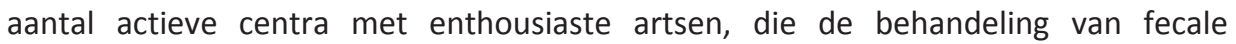




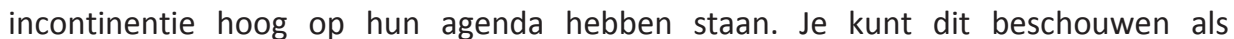

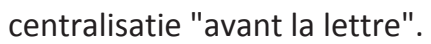

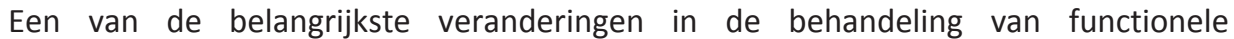

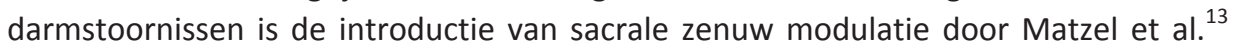

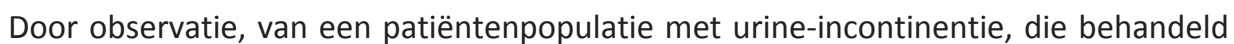

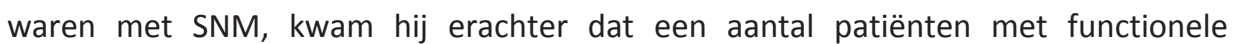

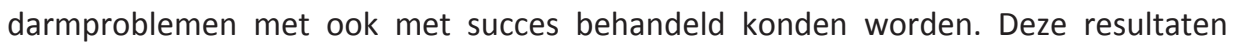

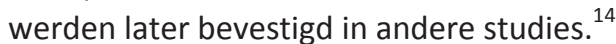

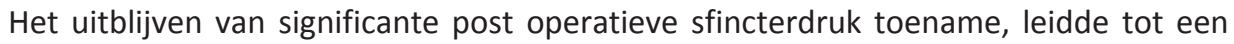

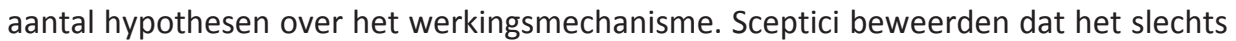

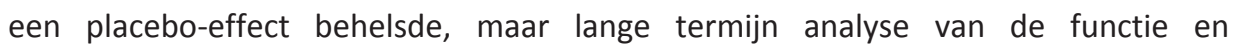

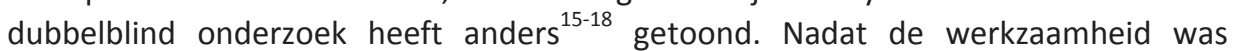

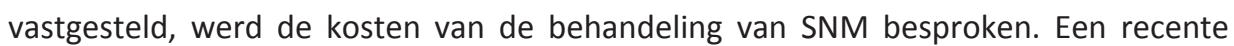

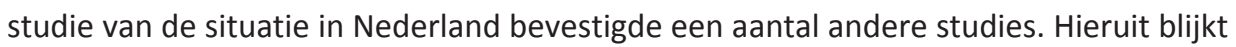

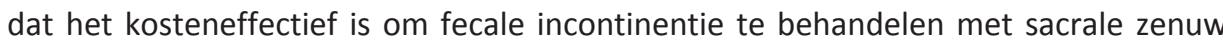

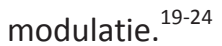

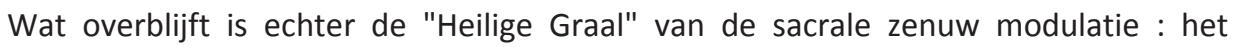

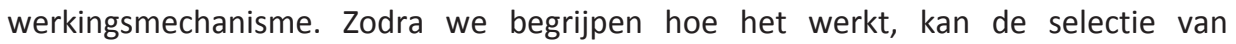

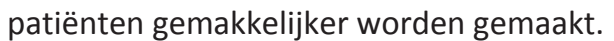

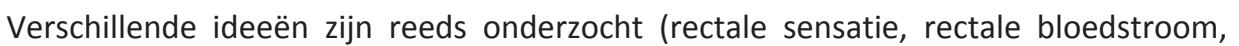

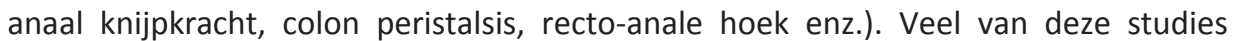

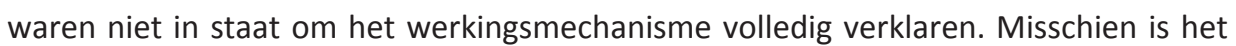
[?]

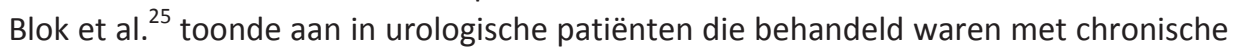

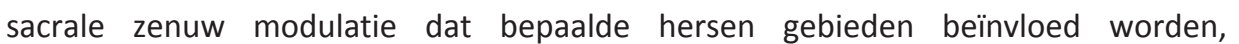

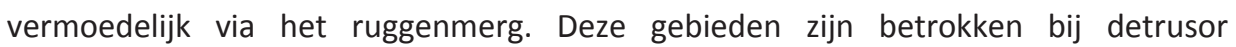

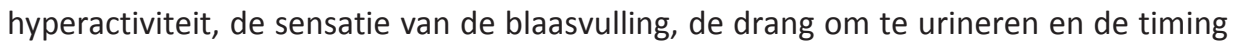

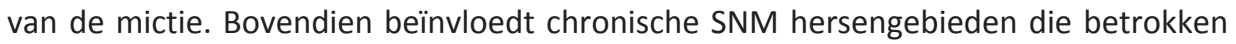

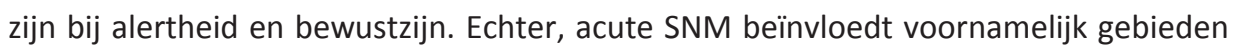

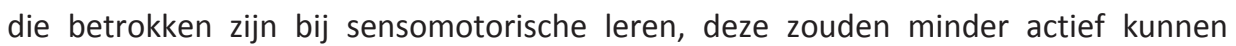

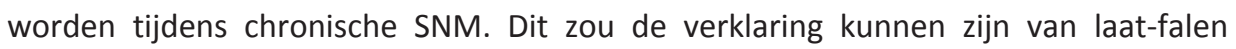

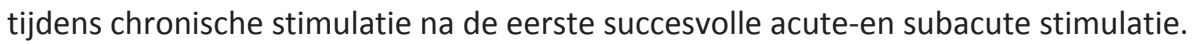

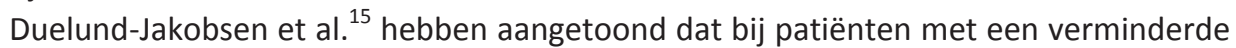

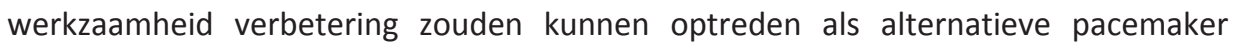

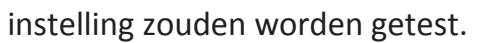

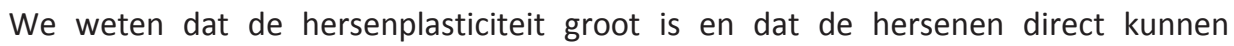

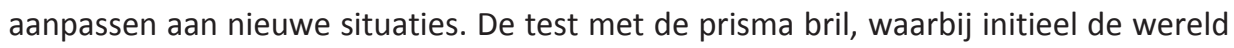

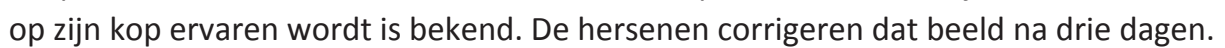

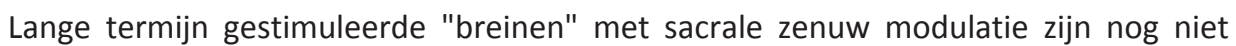

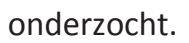




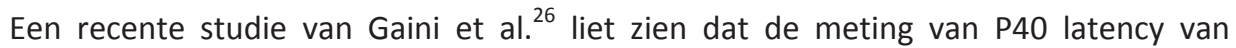

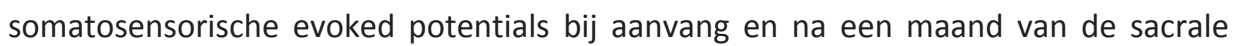

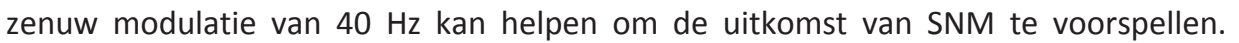

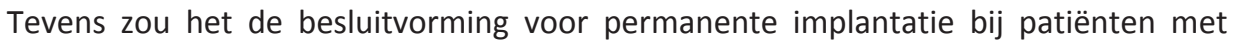

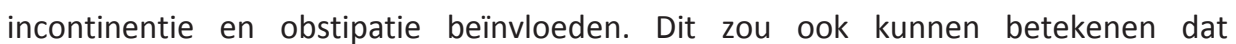

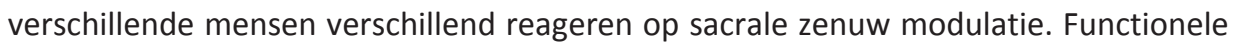

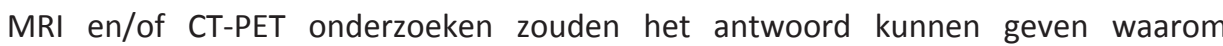

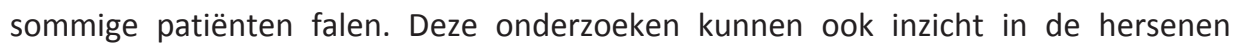

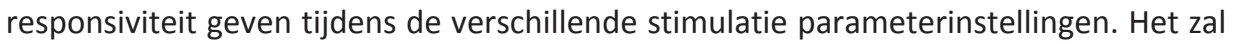

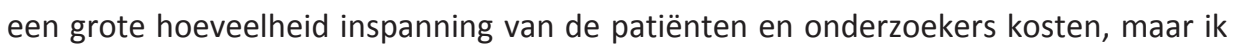

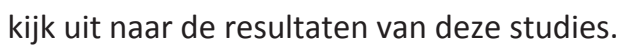




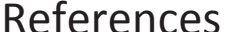

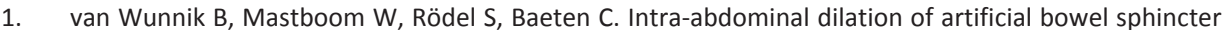

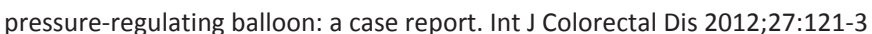

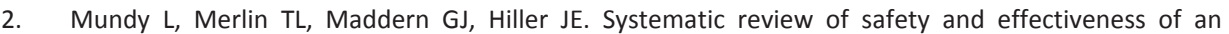

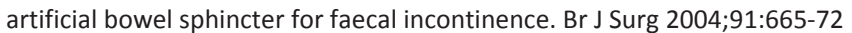

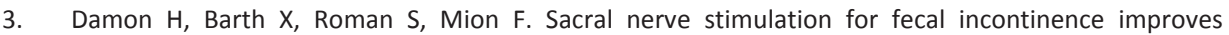

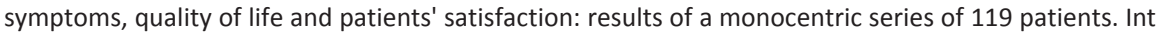

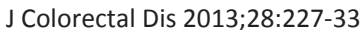

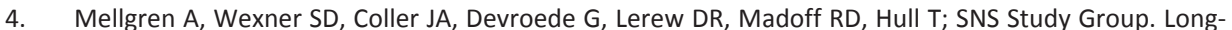

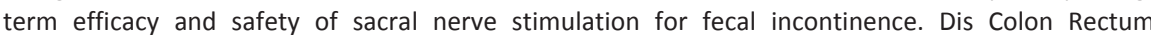

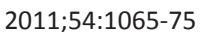

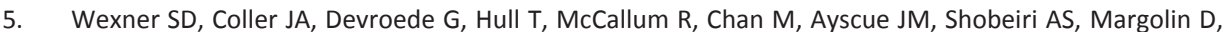

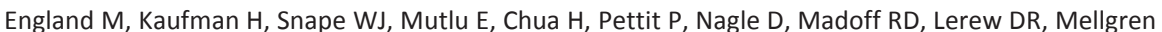

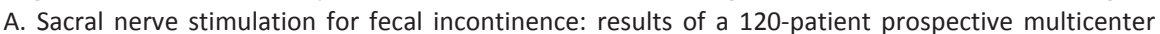

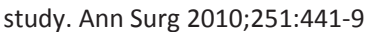

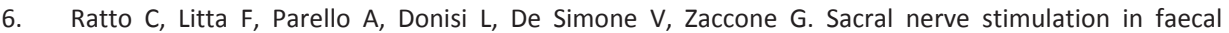

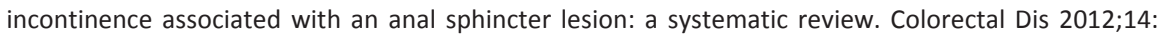

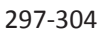

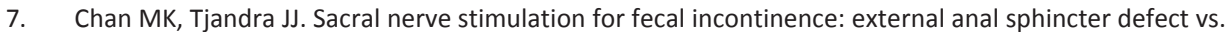

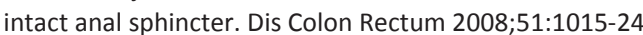

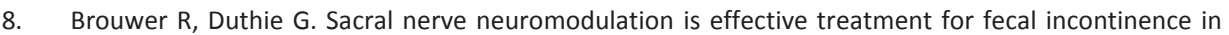

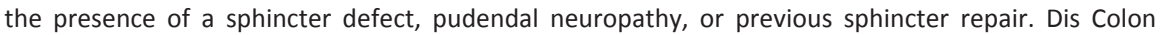

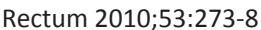

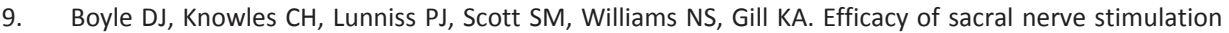

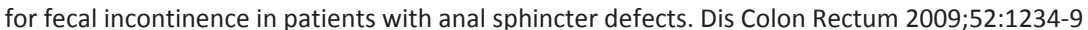

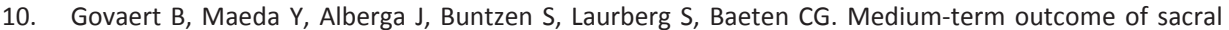

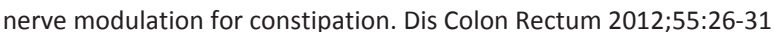

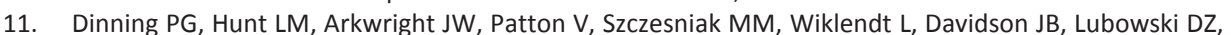

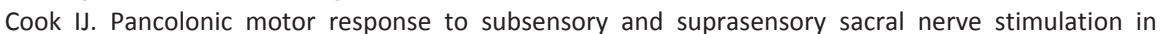

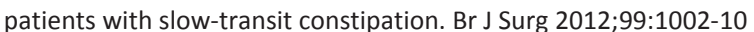

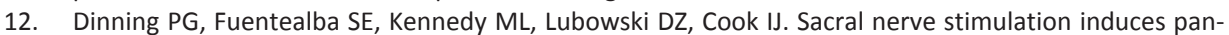

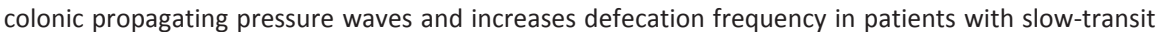

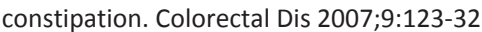

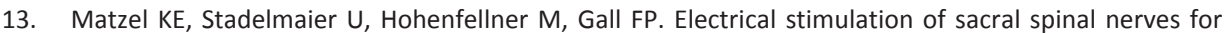

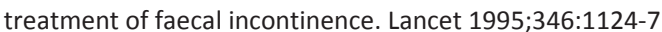

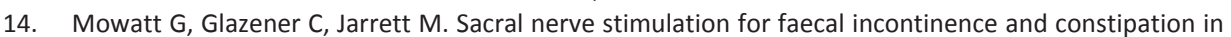

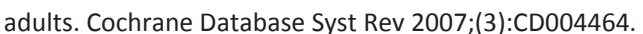

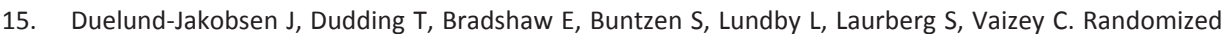

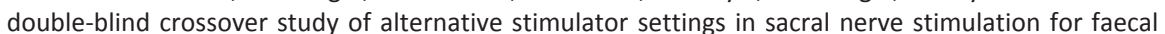

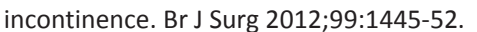

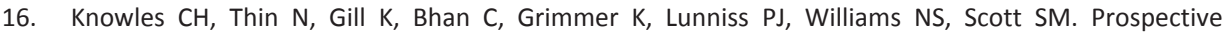

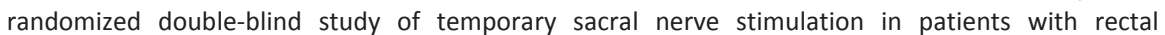

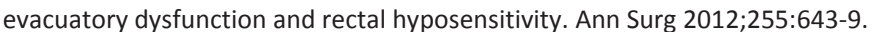

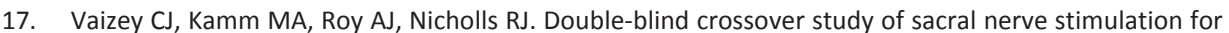

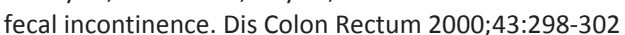

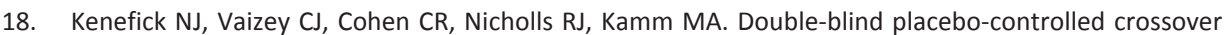

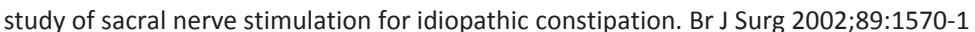

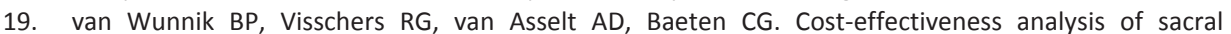

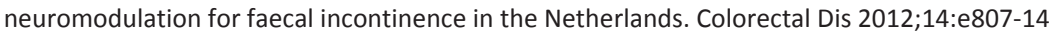

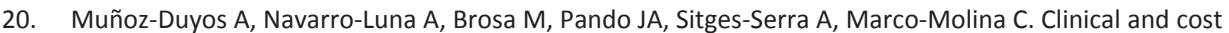

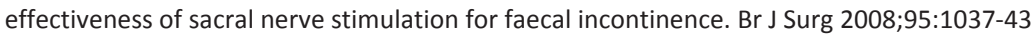

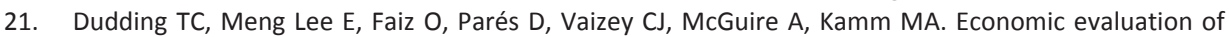

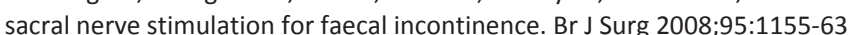




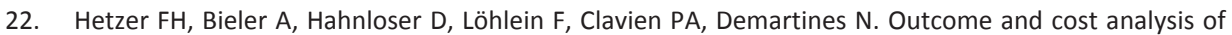

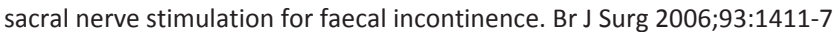

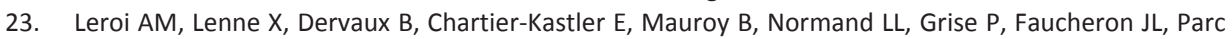

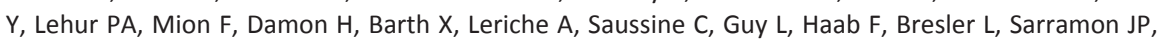

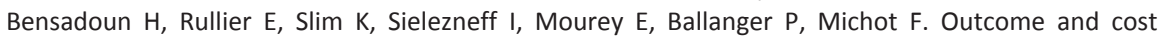

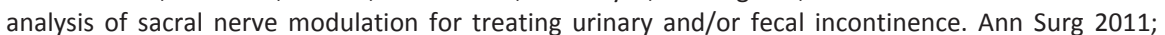

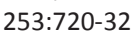

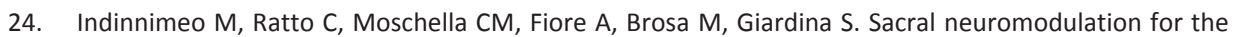

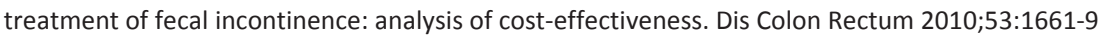

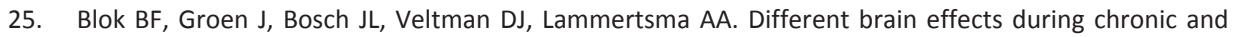

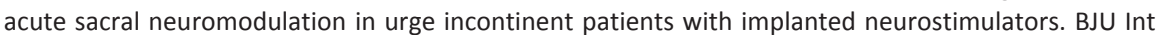

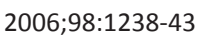

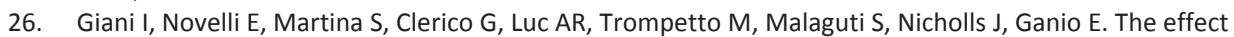

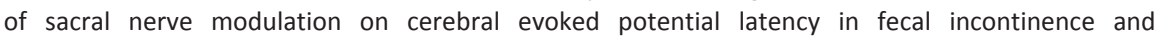

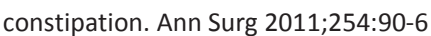




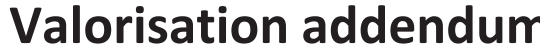




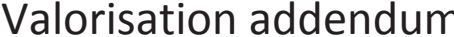

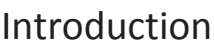

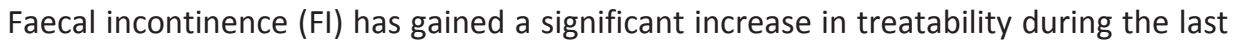

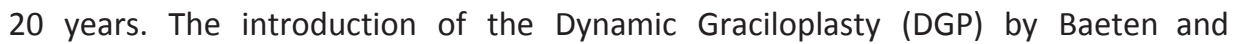

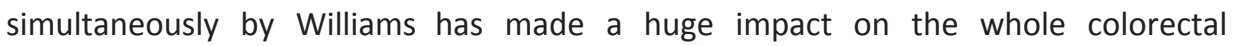

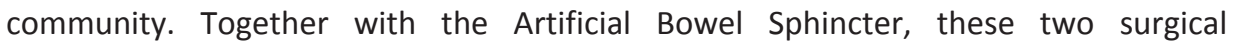

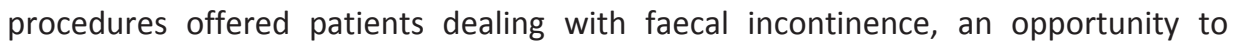

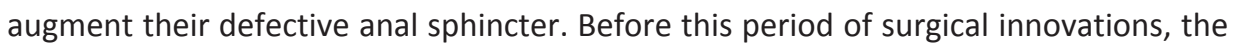

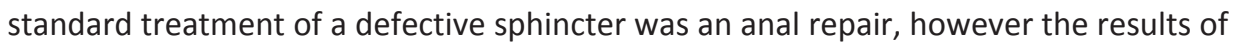

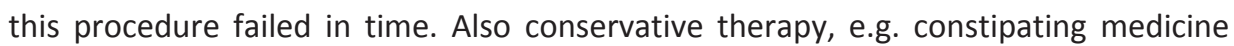

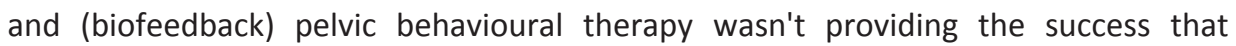

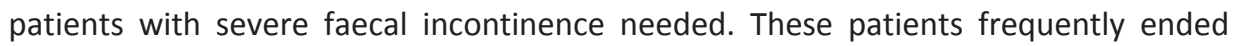

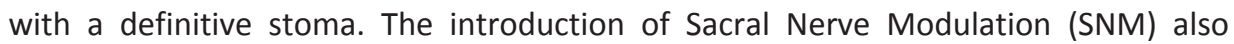

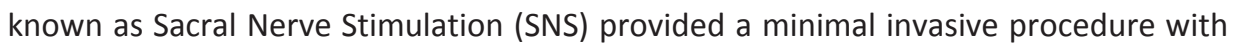

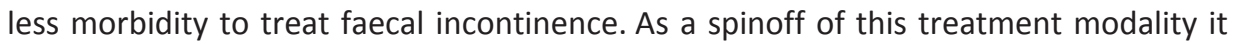

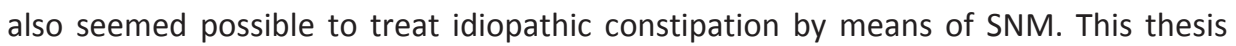

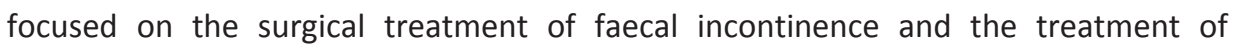

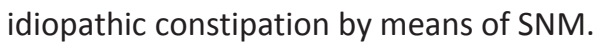

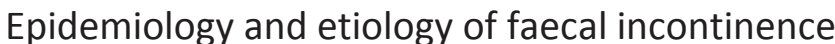

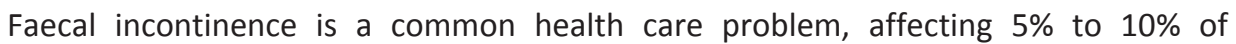

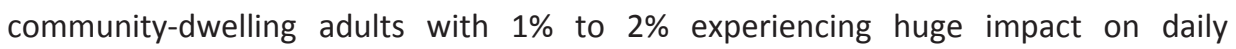

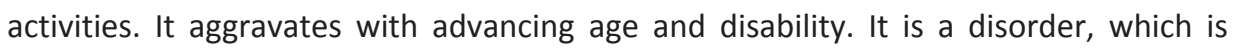

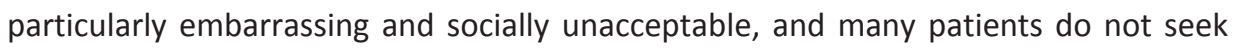

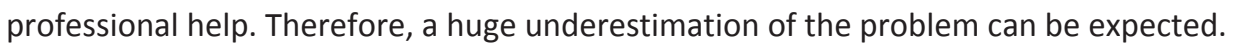

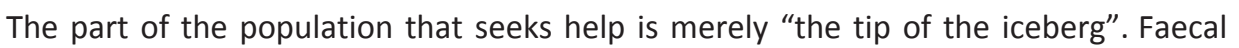

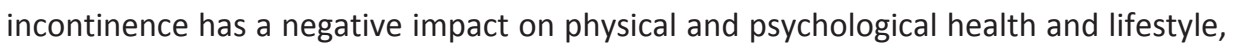

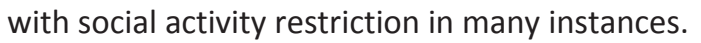

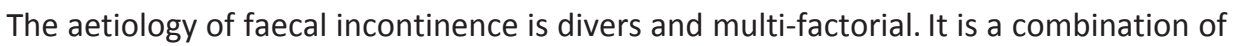

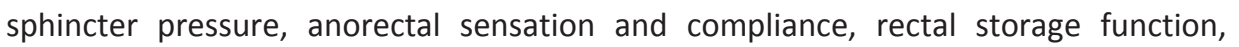

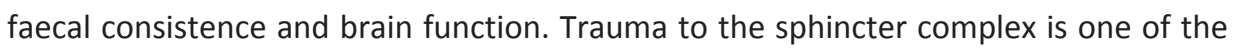

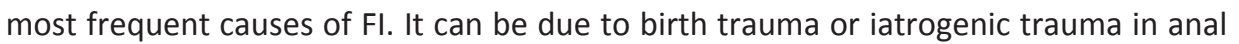

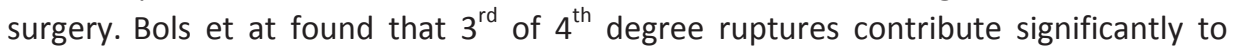

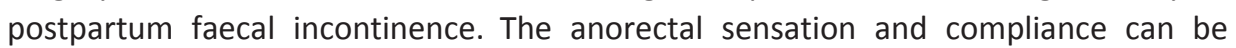

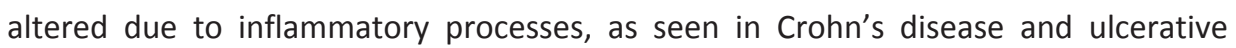

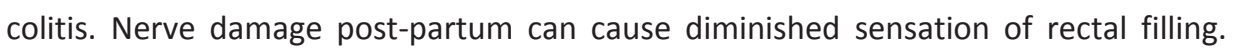

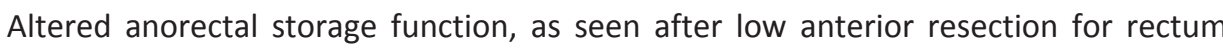

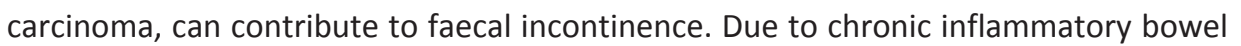

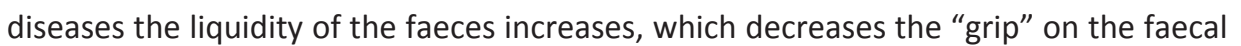




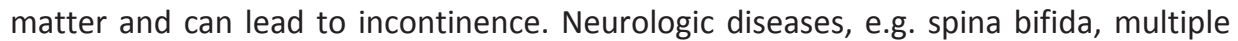

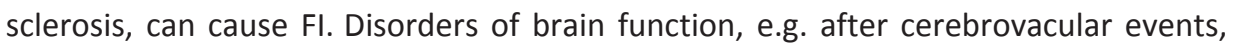

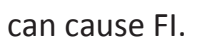

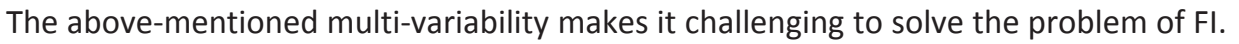

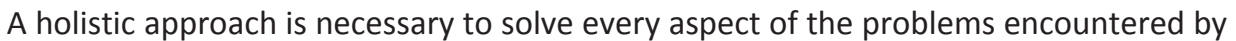

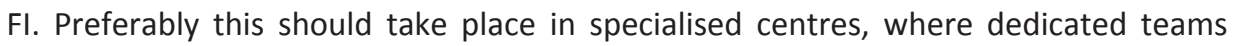

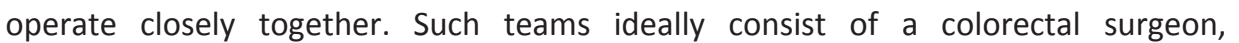

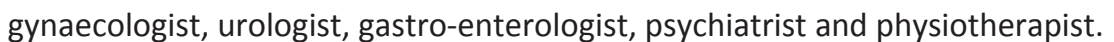

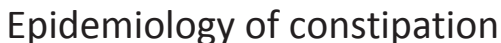

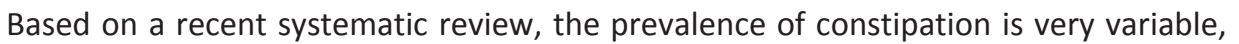

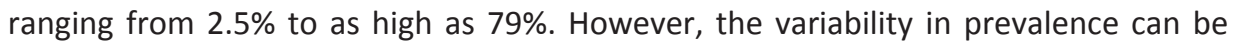

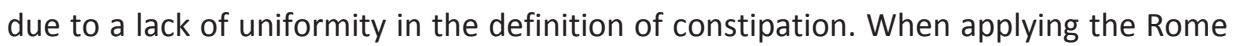

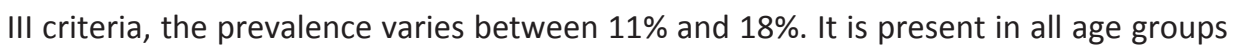

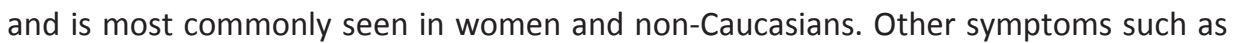

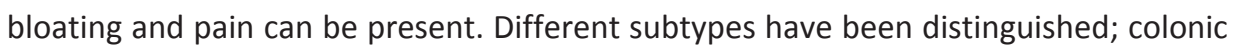

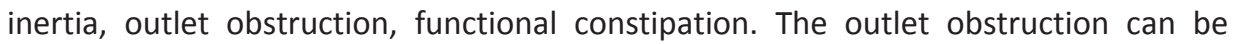

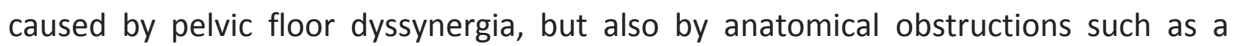

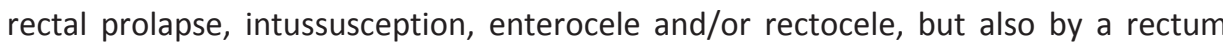

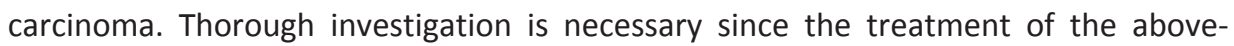

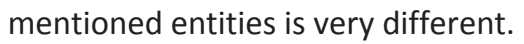

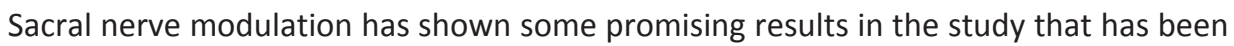

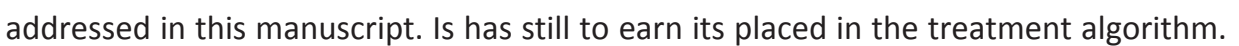

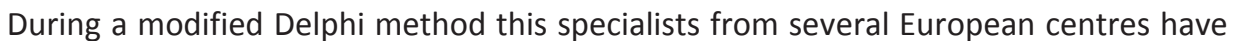

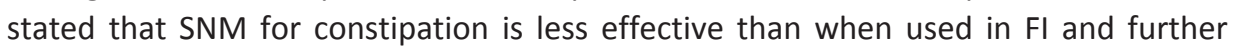

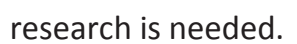

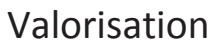

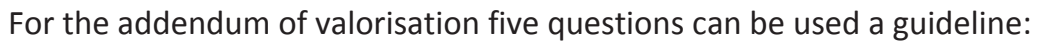

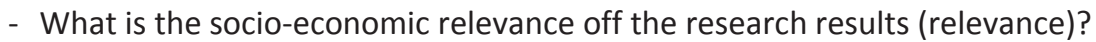

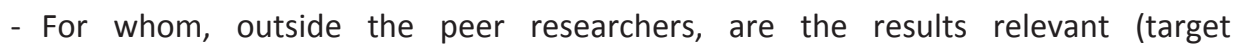

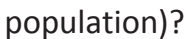

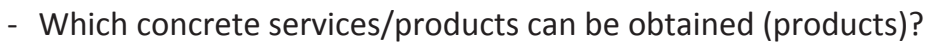

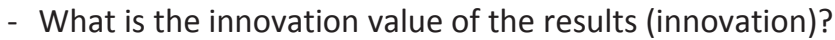

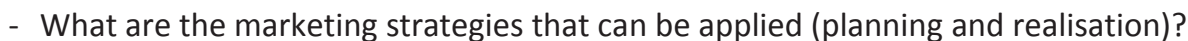




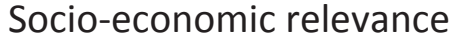

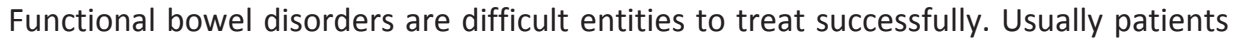

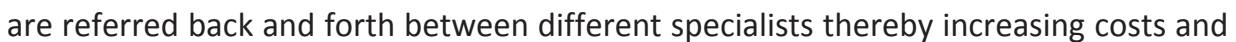

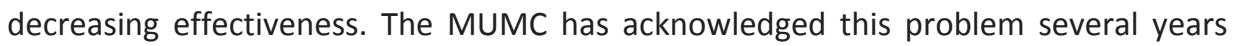

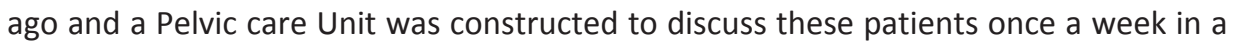

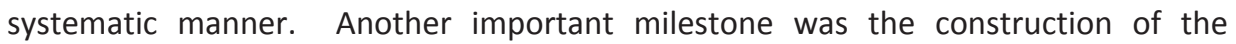

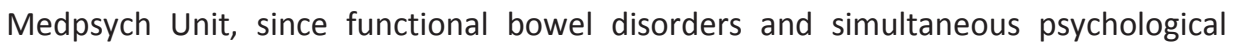

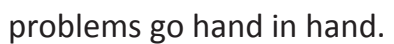

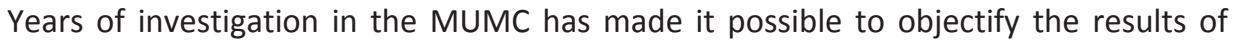

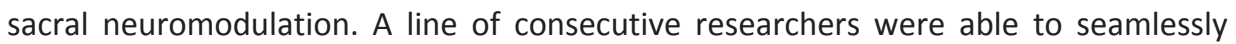

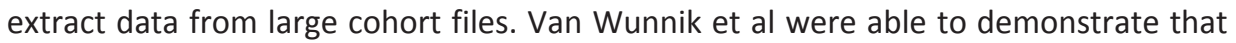

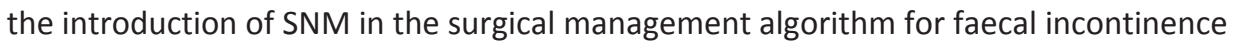

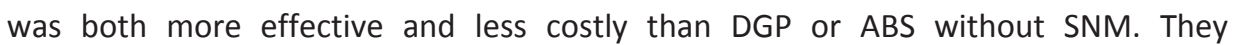

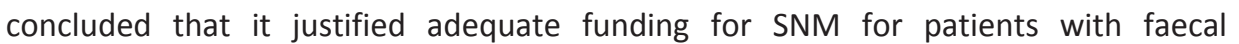

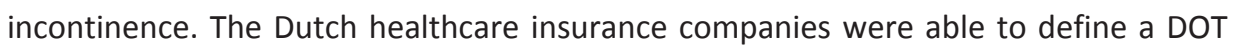

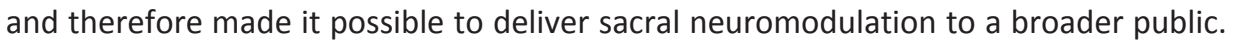

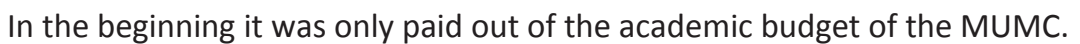

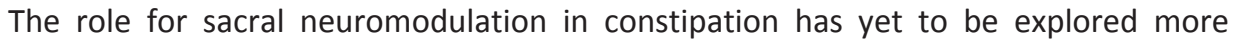

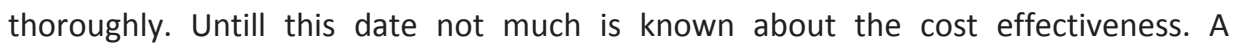

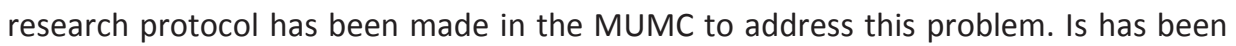

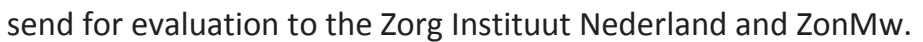

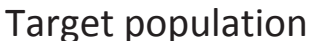

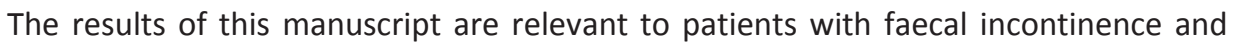

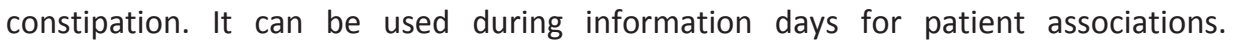

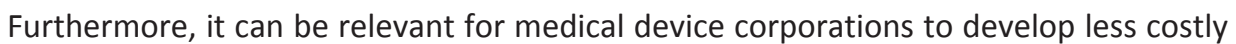

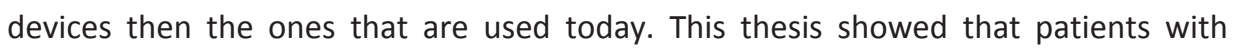

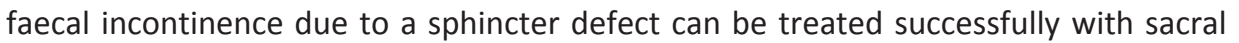

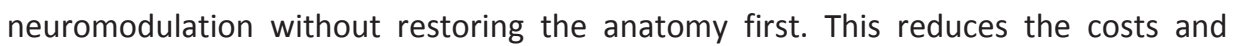

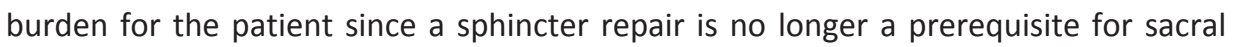

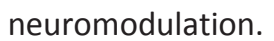

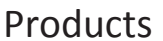

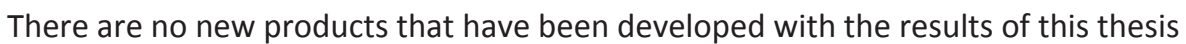

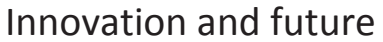

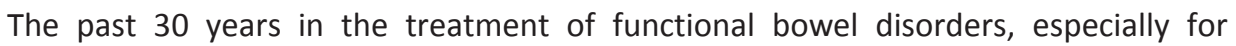

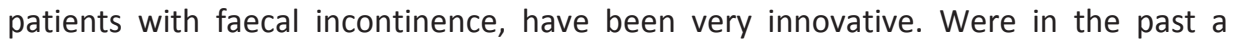

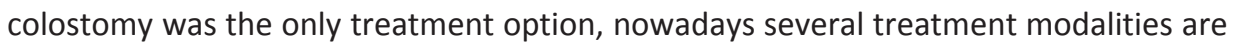




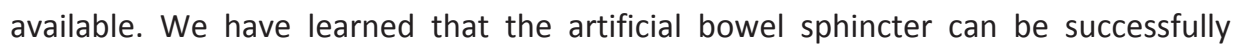

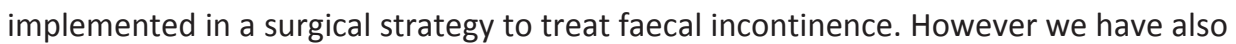

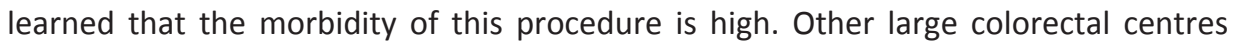

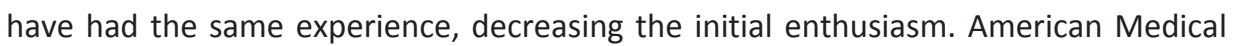

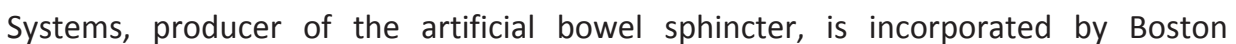

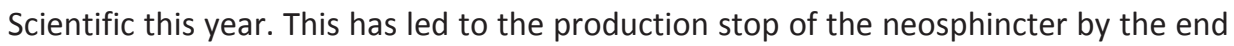

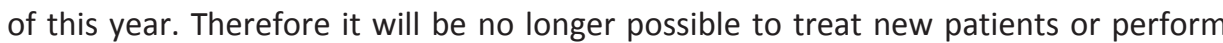

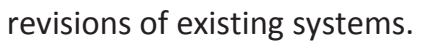

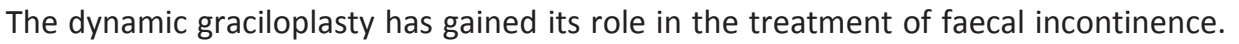

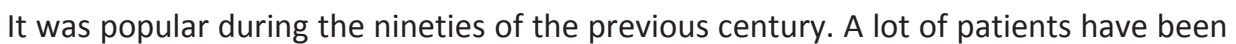

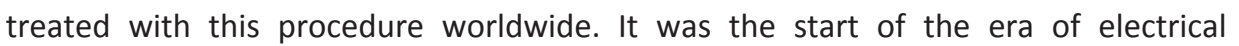

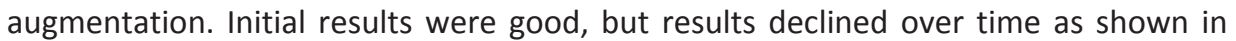

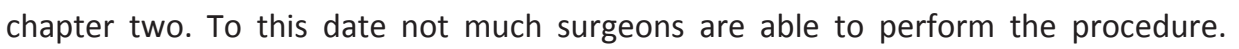

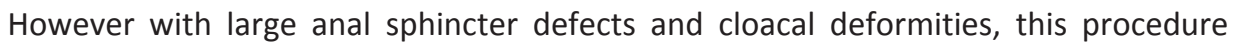

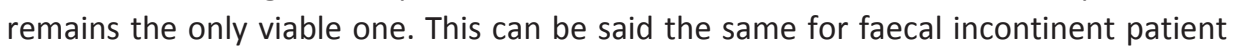

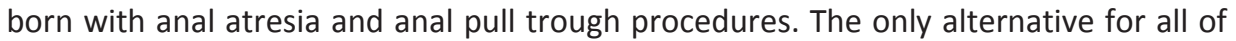

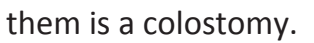

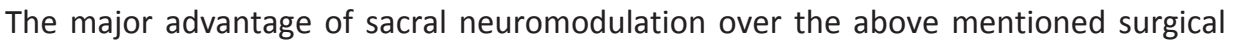

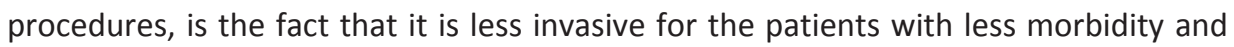

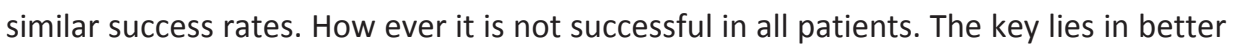

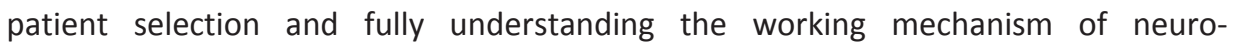

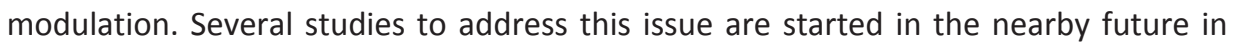

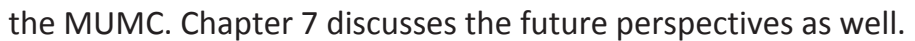




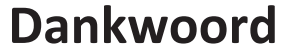




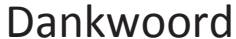

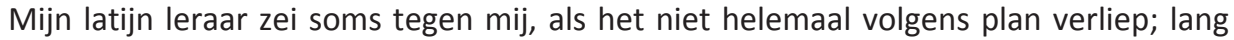

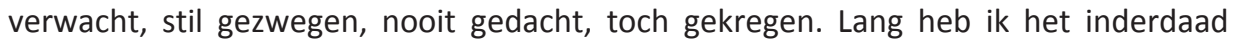

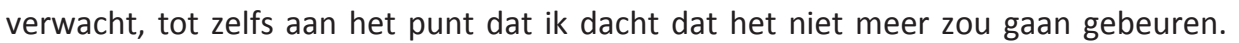

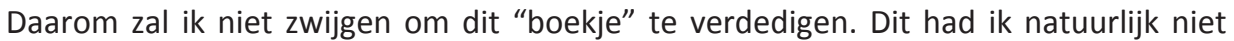

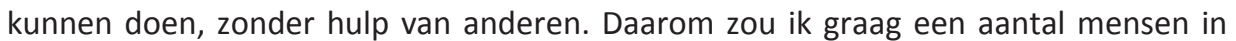

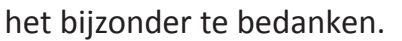

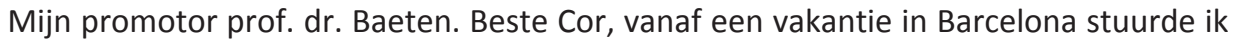

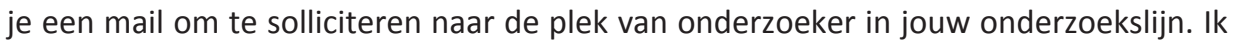

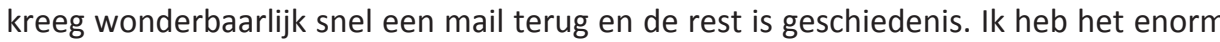

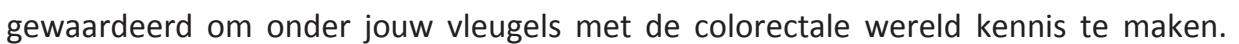

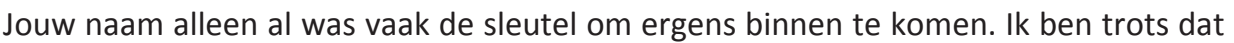

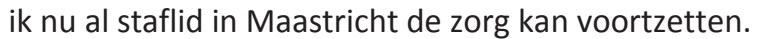

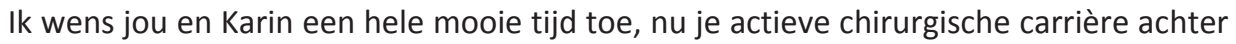

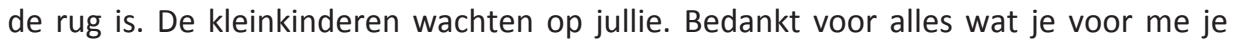

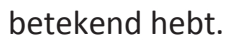

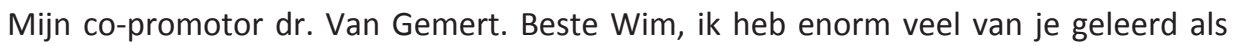

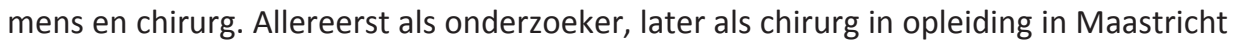

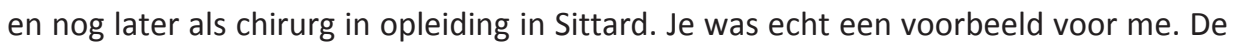

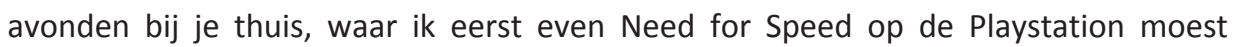

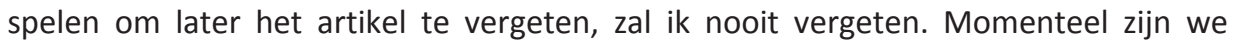

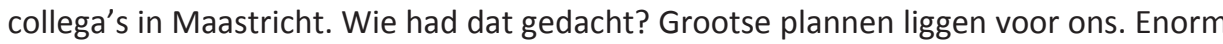

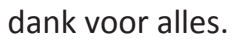

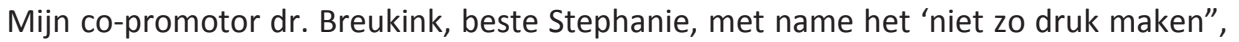

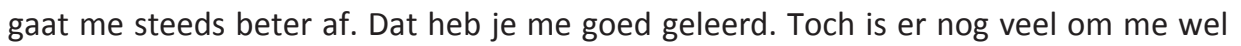

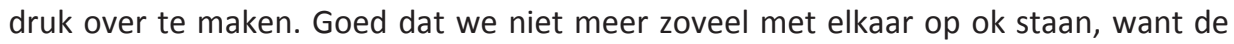

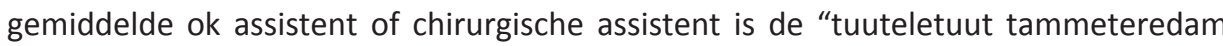

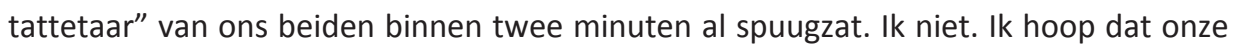

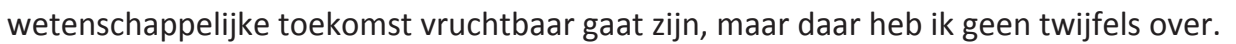

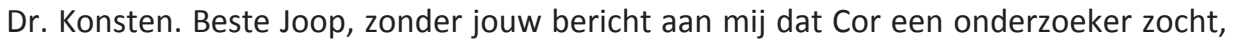

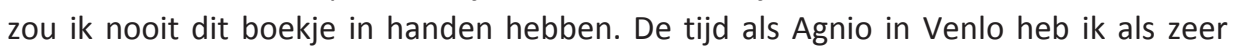

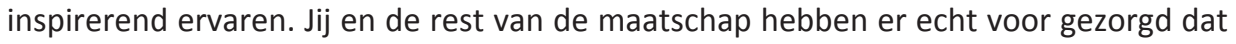

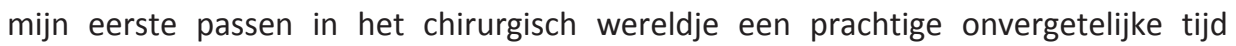

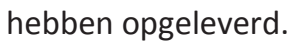




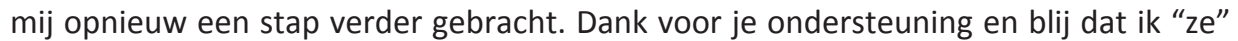

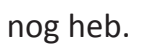

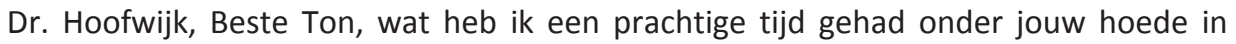

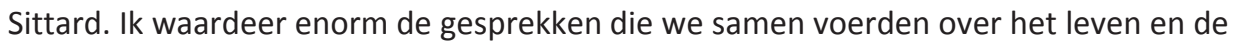

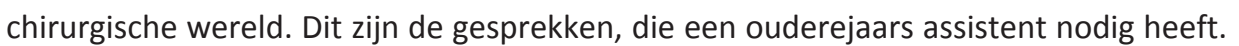

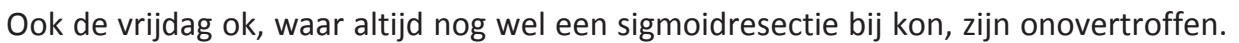

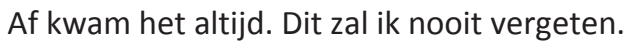

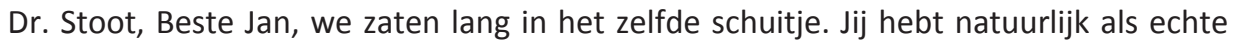

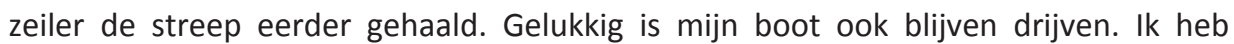

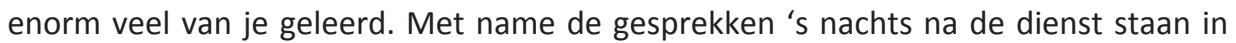

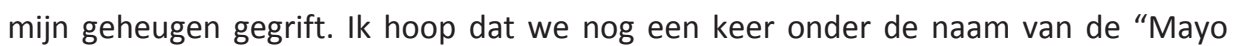

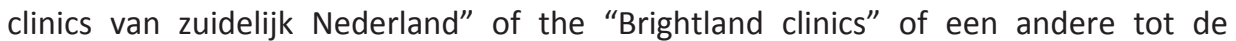

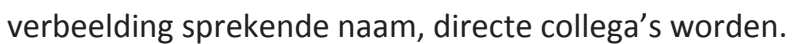

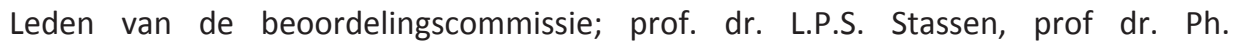

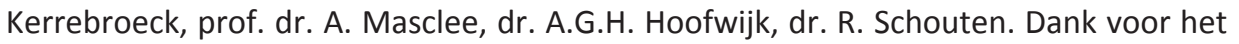

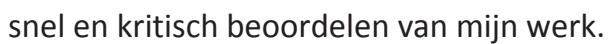

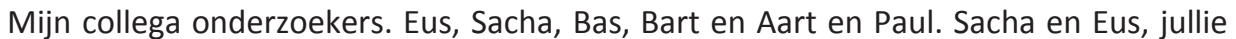

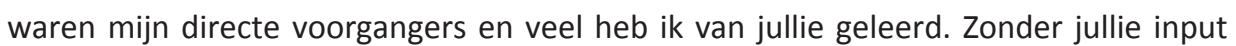

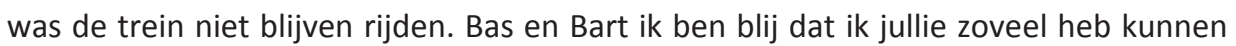

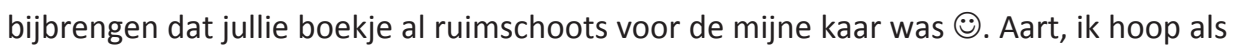

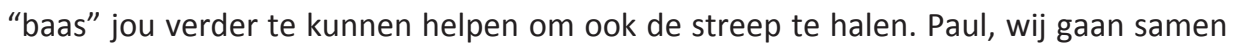

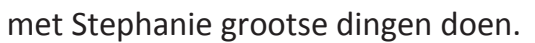

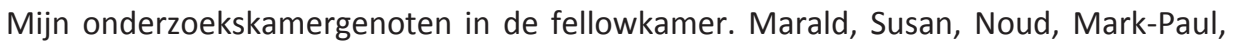

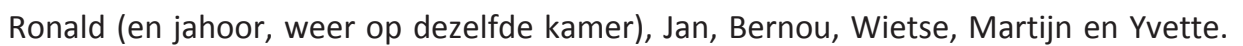

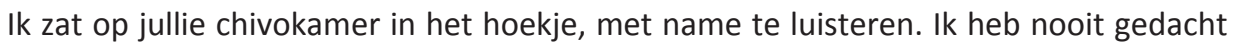

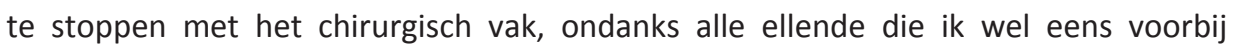

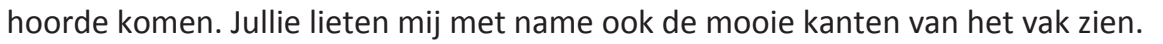

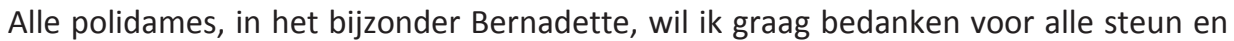

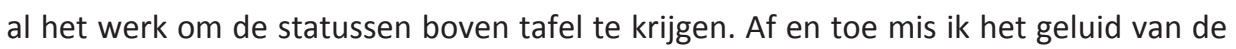

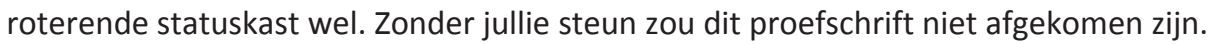

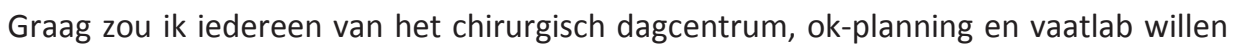

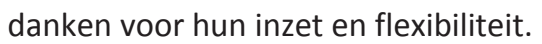




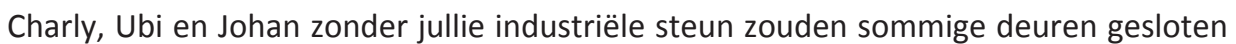

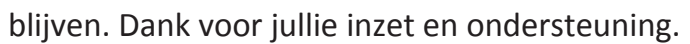

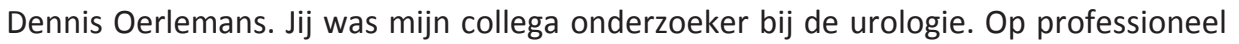

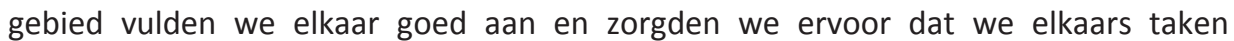

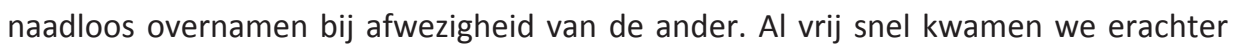

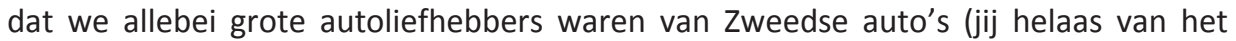

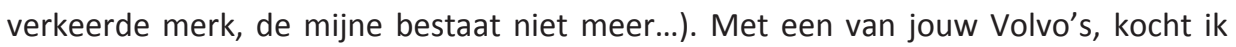

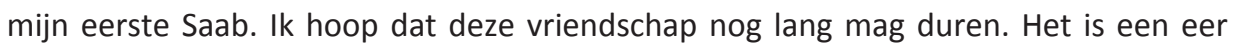

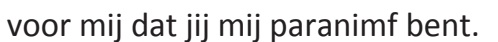

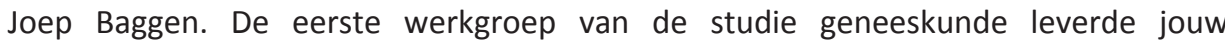

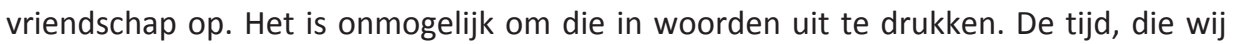

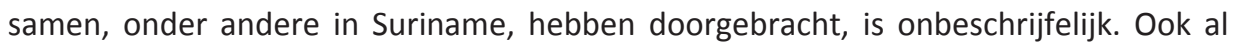

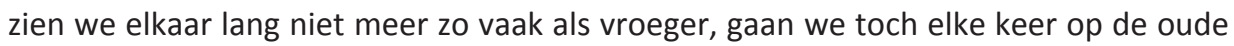

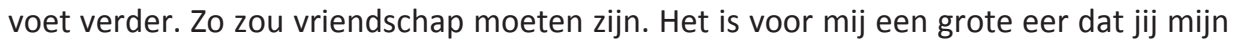

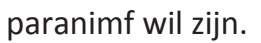

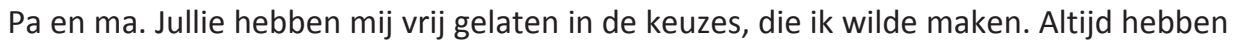
[5

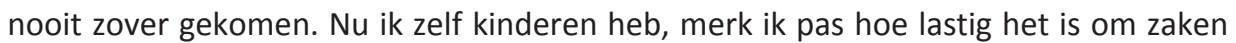

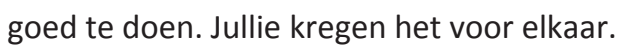

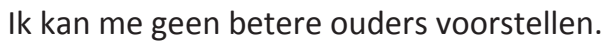

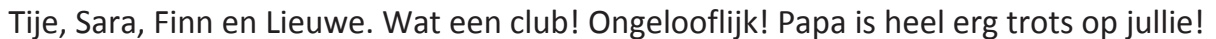

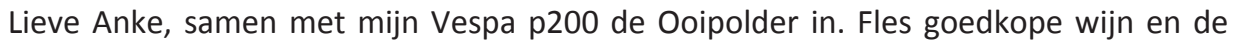

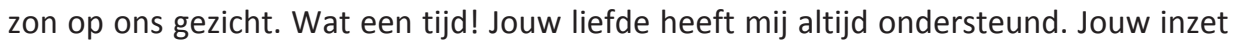

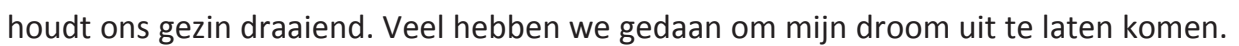

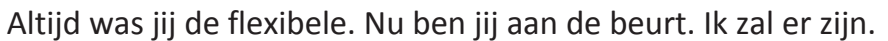




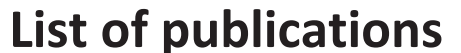




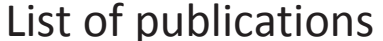

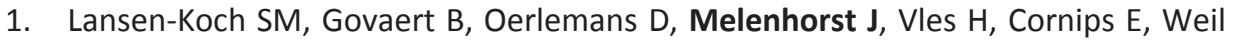

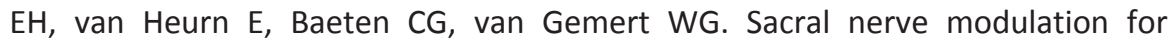

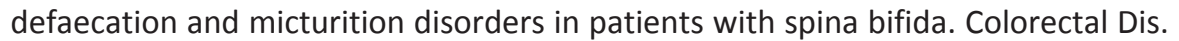

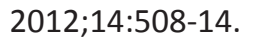

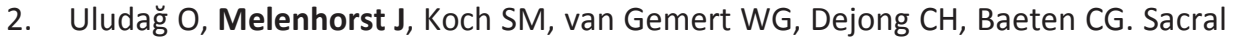

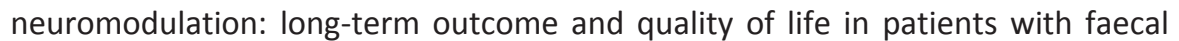

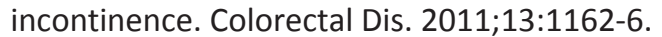

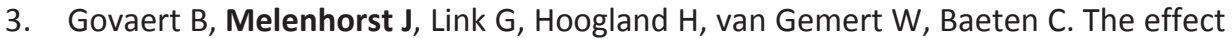

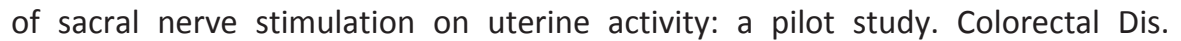

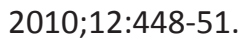

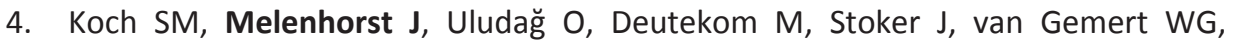

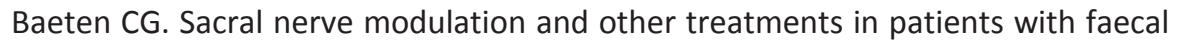

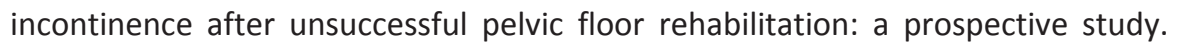

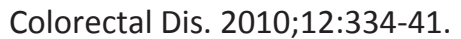

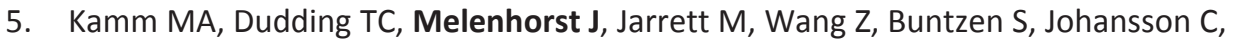

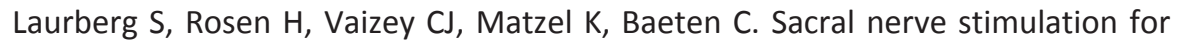

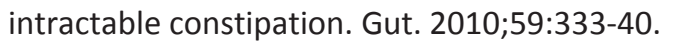

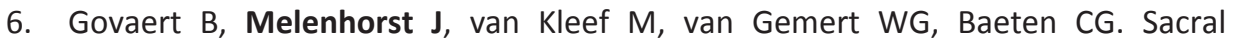

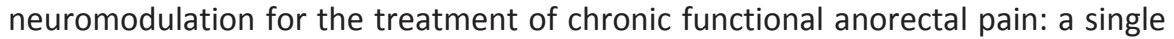

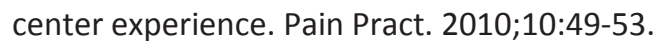

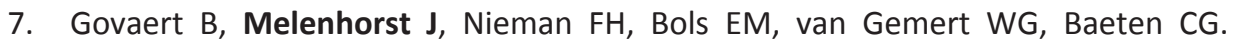

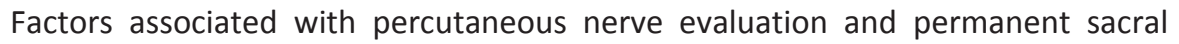

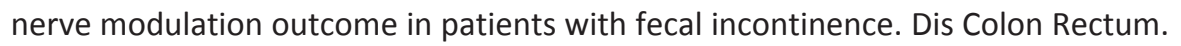

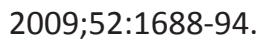

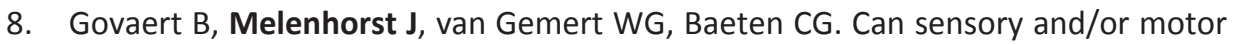

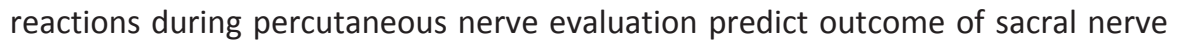

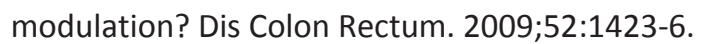

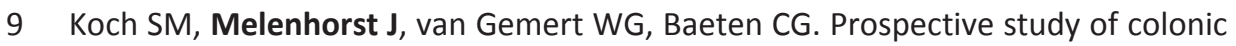

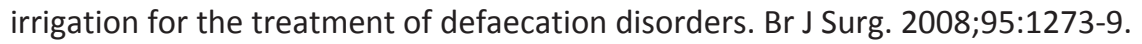




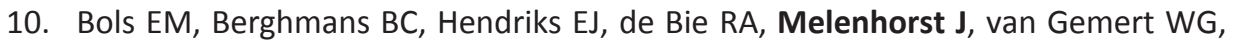

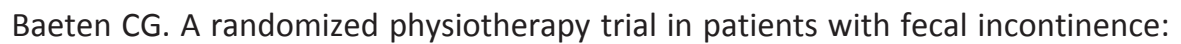

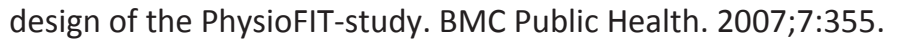

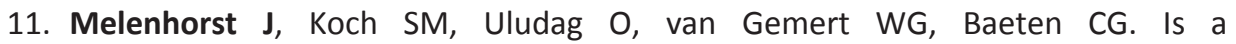

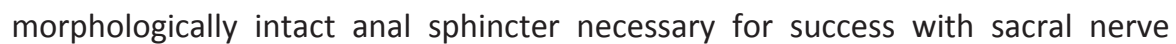

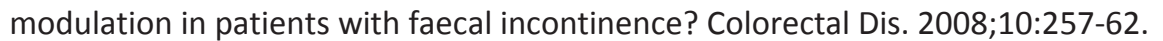

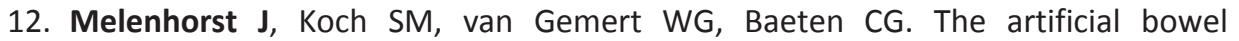

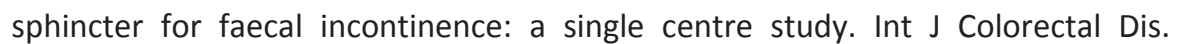

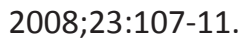

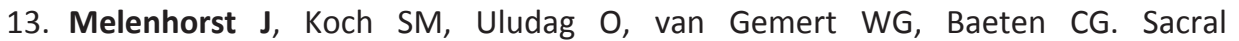

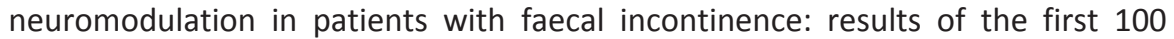

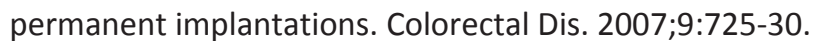

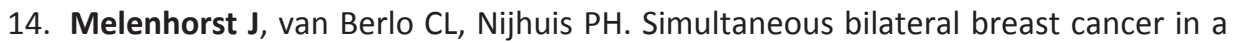

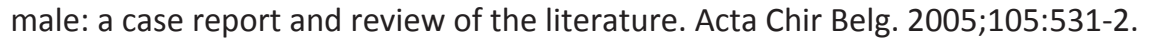

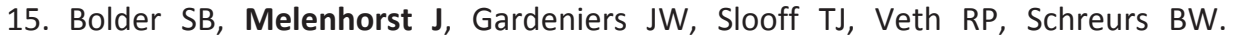

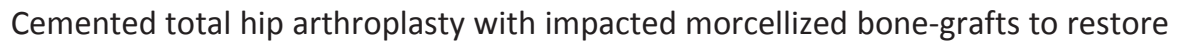

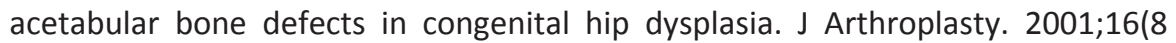

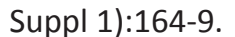




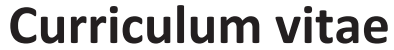




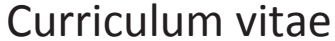

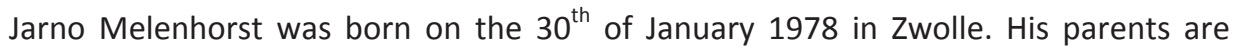

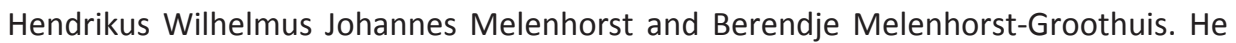

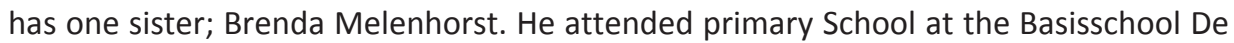
国

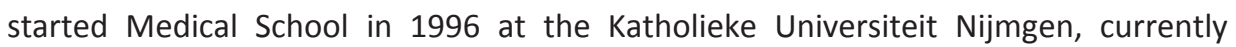

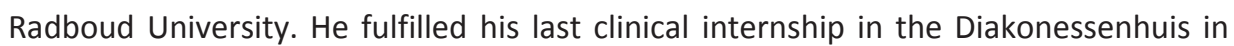

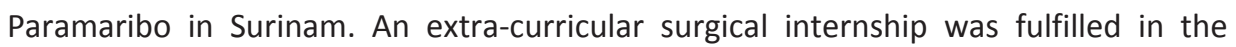

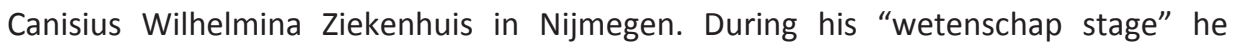

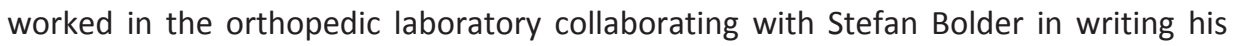

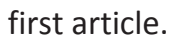

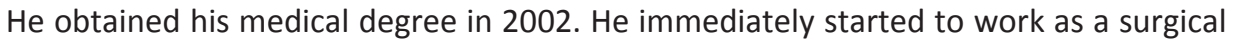

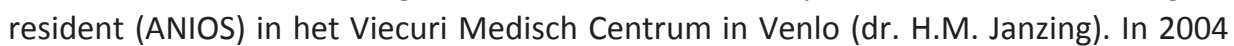

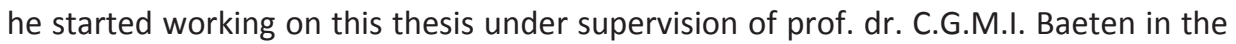

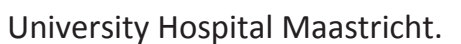

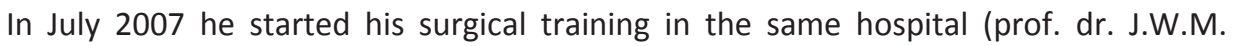

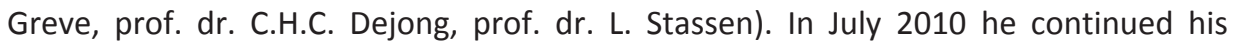

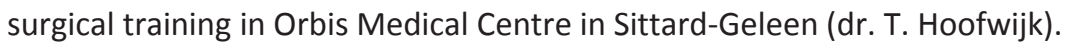

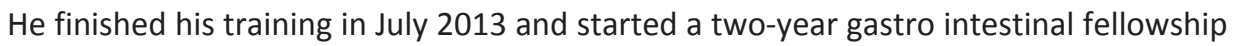

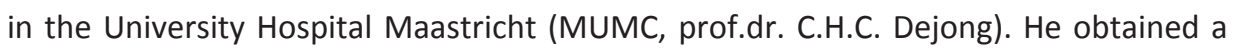

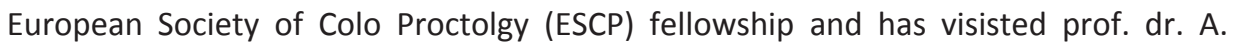

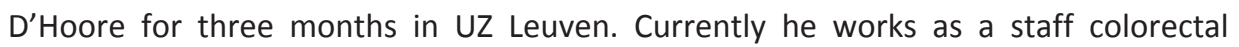

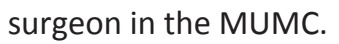

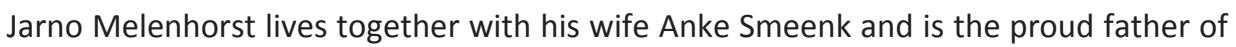

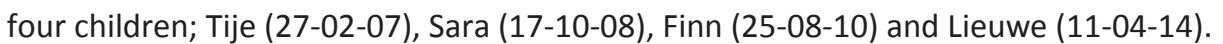


